TOPICAL REPORT

Project No.: 9-61-5329

\title{
TITLE: FIRESIDE CORROSION TESTING OF CANDIDATE SUPERHEATER TUBE ALLOYS, COATINGS, AND CLADDINGS
}

Principal Investigator: S. Van Weele

Program Manager: J. L. Blough

Final Report, August 1991

Report Prepared by:

FOSTER WHEELER DEVELOPMENT CORPORATION

12 Peach Tree Hill Road

Livingston, New Jersey 07039

Prepared for:

OAK RIDGE NATIONAL LABORATORY

Oak Ridge, Tennessee 37831

Managed by:

MARTIN MARIETTA ENERGY SYSTEMS, INC.

for the

U. S. DEPARTMENT OF ENERGY

Under Contract No.:

DE-AC05-840R21400

\section{FOSTER WHEELER DEVELOPMENT CORPORATION Livingston, New Jersey 07039}

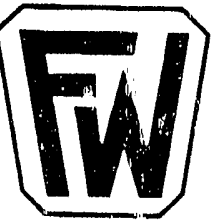


This report has been reproduced directly from the best available copy.

Available to DOE and DOE contractors from the Office of Scientific and Technical Information, P.O. Box 62, Oak, Ridge, TN 37831; prices available from (615) 576 8401 , FTS $626-8401$

Available to the public from the National Technical Information Service, U.S. Department of Commerce, 5285 Port Royal Rd., Springfield, VA 22161.

This report was prepared as an account of work sponsored by an agency of the United States Government. Neither the United States Government nor any agency thereof, nor any of their employees, makes any warranty, expressed or implied, or assumes any legal liability or responsibility for the accuracy, completeness, or usefulness of any information, apparatus, product, or process disclesed, or represents that its use would not infringe privately owned rights. Reference herein to any specific commercial product, process, or service by trade name, trademark, manufacturer, or otherwise, does not necessarily constitute or imply its endorsement, recommendation, or favoring by the Unitad States Government or any agency thereof. The views and opinions of authors expressed herein do not necessarily state or reflect those of the United States Government or any agency thereof. 


\title{
FIRESIDE CORROSION TESTING OF CANDIDATE SUPERHEATER TUBE ALLOYS, COATINGS, AND CLADDINGS
}

\author{
Research sponsored by the U.S. Department of Energy, \\ Fossil Energy \\ Advanced Research and Technology Development Materials Program \\ Report Prepared by \\ FOSTER WHEELER DEVELOPMENT CORPORATION \\ 12 Peach Tree Hill Road \\ Livingston, New Jersey 07039 \\ under
}

Subcontract SA-187-89

for

OAK RIDGE NATIONAL LABORATORY

Oak Ridge, Tennessee 37831

managed by

MARTIN MARIETTA ENERGY SYSTEMS, INC.

for the

U. S. Department of Energy

under Contract No. DE-AC05-840R21400

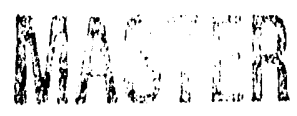




\section{ABSTRACT}

Fireside corrosion, caused by liquid alkali-iron trisulfates, has been an obstacle to higher steam temperatures and to efficient utilization of highsulfur coals. Tests simulating the environment in the superheater bank of a pulverized-coal-fired boiler were conducted on several promising new alloys and claddings. Alloys were exposed to a variety of synthetic ash and simulated flue gas compositions at 650 and $700^{\circ} \mathrm{C}$ for times ranging up to 800 hours.

Included in the testing program were new high-chromium/high-nickel alloys, modified commercial alloys, lean stainless steels (modified Type 316) clad with high-chromium/high-nickel alloys, and intermetallic aluminides.

Thickness loss measurements indicated that resistance to attack improved with increasing chromium level. Silicon and aluminum were also helpful in resisting attack, while molybdenum was detrimental to the resistance of the alloys to attack. Three different attack modes were observed on the alloys tested. Alloys with low resistance to attack exhibited uniform wastage, while pitting was observed in more resistant alloys. In addition to surface fluxing by molten alkali-iron trisulfates, subsurface sulfur penetration and intergranular attack also occurred. 


\section{ACKNOWLEDGMENTS}

I am indebted to Edward M. Davis, Istvan Dojcsanszky, and Robert Carrigan for their assistance in preparing the specimens, conducting the tests, and analyzing the exposed specimens. I thank Irwin Rehn, Greg Stanko, and Eugene Montrone for their guidance and invaluable technical advice. Finally, I wish to acknowledge Hayley Morton and William Marcinko for their patience in formatting and revising this document and Jean Rabe for editing. 
$1 \quad$ INTRODUCTION

2 EXPERIMENTAL APPROACH AND TEST PLAN 2

2.1 Simulating Boiler Conditions in the Laboratory 2

2.1.1 Simulated Flue Gas Creation 2

2.1.2 Synthetic Fuel Ash Preparation 2

2.1.3 Furnace and Experimental Retort 4

2.2 Materials Selection 4

2.3 Overview of Testing Sequence 4

2.3.1 Initial Characterization of Coupons 4

2.3.2 Preparing Coupons Before Exposure 7

2.3.3 Exposing Specimens to a Simulated Boiler

2.3.4 Post-Exposure Steam Cleaning and Recoating 7

2.3.5 Post-Test Cleaning and Descaling of Coupons 8

2.4 Methods of Eva?uating Corrosion Losses and Mor-

phology of Attack

2.4.1 Visual Evaluation 8

2.4.2 Weight Loss, Thickness Loss, and Pit Depth
Measurements

2.4.3 Microscopic Examination and Chemical Analysis 9

3 RESULTS OF FIRESIDE TESTING 10

3.1 Results of the 100 - and 200-Hour High-Sulfate
0.25 vol\% $\mathrm{SO}_{2}$ Tests

3.1.1 Weight Loss 11

3.1.2 Thickness Losses 11

3.2 Results of the 100- and 800-Hour Low-Sulfate

0.25 vol\% $\mathrm{SO}_{2}$ Tests $\quad 18$

3.2.1 Weight Loss 18

3.2.2 Thickness Losses 18

3.3 Results of the 100- and 800-Hour Low-Sulfate

1.0 vol\% $\mathrm{SO}_{2}$ Tests 25

3.3.1 Weight Loss 25

3.3.2 Thickness Losses $\quad 25$

3.4 Evaluation of Chromized Specimens 32

3.5 Evaluation of Lean Stainless Steel Clad With Type 671 


\section{Contents (Cont)}

Section

4 EFFECTS OF ENVIRONMENTAL VARIABLES AND COMPOSITION ON RESISTANCE OF MATERIALS TO ALKALI-IRON TRISULFATE ATTACK

4.1 Effects of Chromium on Alloy Resistance

4.2 Effects of Other Alloying Elements on Alloy Resistance

4.3 Clad Alloys

4.4 Aluminide Alloys

4.5 Influence of Erivironment on Wastage Rates

4.6 Macroscopic Examination of Exposed Specimens

4.7 Microscopic Analys is of Coupons and Corrosion Products

4.8 Analysis of $\mathrm{Clad}$ Coupons

5 DETERMINATION OF OBSERVED WASTAGE MECHANISMS

5.1 Possible Mechanisms of Molten AIT Attack on Iron- or Nickel-Based Alloys

5.2 Subsurface Effects During Molten AIT Attack

5.3 Mechanisms of Attack on Intermetallic Aluminides

5.4 How Material and Environmental Variables Affect Corrosion Resistance

6 CONCLUSIONS AND RECOMMENDATIONS

7 REFERENCES

APPENDIX A

APPENDIX B 


\section{Tables}

Number

2.1 Ash Compositions

2.2 Composition of Alloys Examined

2.3 Test Exposure Conditions

7

2.4 Cleaning Solutions Compositions

3.1 Visual Evaluations of Chromized Specimens Exposed to Various Simulated Boiler Environments

3.2 Visual Evaluations of Lean Stainless Steel Clad With Type 671 to Various Simulated Boiler Environments 


\section{Figures}

Number

2.1 Gas Train Schematic

2.2 Furnace Experimental Retort

3.1 Normalized Weight Loss Rates for Alloys Coated With a 75 wt\% Alkali Sulfate Ash and Exposed at $650^{\circ} \mathrm{C}$ to a $0.25 \mathrm{vol}^{2} \mathrm{SO}_{2}$ Flue Gas

3.2 Normalized Weight Loss Rates for Alloys Coated With a 75 wt\% Alkali Sulfate Ash and Exposed at $700^{\circ} \mathrm{C}$ to a 0.25 vol\% $\mathrm{SO}_{2}$ Flue Gas

3.3 Normalized Thickness Loss Rates for Alloys Coated With a 75 wt\% Alkali Sulfate Ash and Exposed at $650^{\circ} \mathrm{C}$ to a 0.25 vol\% $\mathrm{SO}_{2}$ Flue Gas

3.4 Normalized Thickness Loss Rates for Alloys Coated With a 75 wt\% Alkali Sulfate Ash and Exposed at $700^{\circ} \mathrm{C}$ to a 0.25 vol\% $\mathrm{SO}_{2}$ Filue Gas

3.5 Normalized Maximum Thickness Loss Rates for Alloys Coated With a 75 wt\% Alkali Sulfate Ash and Exposed at $650^{\circ} \mathrm{C}$ to a 0.25 vol\% $\mathrm{SO}_{2}$ Flue Gas

3.6 Normalized Maximum Thickness Loss Rates for Alloys Coated With a 75 wt\% Alkali Sulfate Ash and Exposed at $700^{\circ} \mathrm{C}$ to a 0.25 vol\% $\mathrm{SO}_{2}$ Flue Gas

3.7 Normalized Weight Loss Rates for Alloys Coated With a 10 wt\% Alkali Sulfate Ash and Exposed at $650^{\circ} \mathrm{C}$ to a 0.25 vol\% $\mathrm{SO}_{2}$ Flue Gas

3.8 Normalized Weight Loss Rates for Alloys Coated With a $10 \mathrm{wt \%}$ Alkali Sulfate Ash and Exposed at $700^{\circ} \mathrm{C}$ to a 0.25 vol\% $\mathrm{SO}_{2}$ Flue Gas

3.9 Normalized Thickness Loss Rates for Alloys Coated With a 10 wt\% Alkali Sulfate Ash and Exposed at $650^{\circ} \mathrm{C}$ to a 0.25 vol\% $\mathrm{SO}_{2}$ Flue Gas

3.10 Normalized Thickness Loss Rates for Alloys Coated With a 10 wt\% Alkali Sulfate Ash and Exposed at $700^{\circ} \mathrm{C}$ to a 0.25 vol\% $\mathrm{SO}_{2}$ Flue Gas

3.11 Normalized Maximum Thickness Loss Rates for Alloys Coated With a 10 wt\% Alkali Sulfate Ash and Exposed at $650^{\circ} \mathrm{C}$ to a 0.25 vol\% $\mathrm{SO}_{2}$ Flue Gas

3.12 Normalized Maximum Thickness Loss Rates for Alloys Coated With a 10 wt\% Alkali Sulfate Ash and Exposed at $700^{\circ} \mathrm{C}$ to 0.25 vol\% $\mathrm{SO}_{2}$ Flue Gas 
Figures (Cont)

Number

Page

3.13 Normalized Weight Loss Rates for Alloys Coated With an Ash Containing $10 \mathrm{wt} \%$ Alkali Sulfates and Exposed at $650^{\circ} \mathrm{C}$ to a Flue Gas Containing 1.0 vol\% $\mathrm{SO}_{2}$

3.14 Normalized Weight Loss Rates for Alloys Coated With an Ash Containing 10 wt\% Alkali Sulfates and Exposed at $700^{\circ} \mathrm{C}$ to a Flue Gas Containing 1.0 vol\% $\mathrm{SO}_{2}$

3.15 Normalized Weight Loss Rates for Alloys Coated With an Ash Containing 10 wt\% Alkali Sulfates and Exposed at $650^{\circ} \mathrm{C}$ to a Flue Gas Containing 1.0 vol\% $\mathrm{SO}_{2}$

3.16 Normalized Thickness Loss Rates for Alloys Coated With an Ash Containing 10 wt\% Alkali Sulfates and Exposed at $700^{\circ} \mathrm{C}$ to a Flue Gas Containing 1.0 vol\% $\mathrm{SO}_{2}$

3.17 Normalized Maximum Thickness Loss Rates for Alloys Coated With an Ash Containing 10 wt\% Alkali Sulfates and Exposed at $650^{\circ} \mathrm{C}$ to a Flue Gas Containing 1.0 vol\% $\mathrm{SO}_{2}$

3.18 Normalized Maximum Thickness Loss Rates for Alloys Coated With an Ash Containing 10 wt\% Alkali Sulfates and Exposed at $700^{\circ} \mathrm{C}$ to a Flue Gas Containing 1.0 vol\% $\mathrm{SO}_{2}$

4.1 Average Thickness Loss Rate of Alloy Compared With Chromium Content of Alloy (Plot contains data for all alloys exposed under every environment tested in program.)

4.2 Average Thickness Loss Rate of Alloy Compared With Chromium Content of Alloy (Plot contains data for alloys exposed to flue gas containing 0.25 vol\% $\mathrm{SO}_{2}$ and coated with ash containing 10 wt\% alkali sulfates.)

4.3 Average Thickness Loss Rate of Alloy Compared With Chromium Content of Alloy (Plot contains data for alloys exposed to flue gas containing 1.0 vol\% $\mathrm{SO}_{2}$ and coated with ash containing 10 wt\% alkali sulfates.)

4.4 Average Thickness Loss Rate of Alloy Compared With Chromium Content of Alloy (Plot contains data for alloys exposed to flue gas containing 0.25 vol\% $\mathrm{SO}_{2}$ and coated with ash containing 75 wt\% alkali sulfates.)

4.5 Average Thickness Loss Rate of Alloys Containing 14- to 30-Percent Chromium

4.6 Average Thickness Loss Rates of Various Monolithic Alloys and Claddings Coated With Ash Containing 10 wt\% Alkali

Sulfates and Exposed for 800 Hours 


\section{Figures (Cont)}

Number

Page

4.7 Average Thickness Loss Rates of Three Intermetal?ic Aluminides and Two Stainless Steels Exposed to a Variety of Environments

4.8 Average Thickness Loss Rates of Representative Alloys Coated With Ash Containing 10 wt\% Alkali Sulfates and Exposed at 650 and $700^{\circ} \mathrm{C}$ for 800 Hours to Flue Gas Containing 0.25 vol\% $\mathrm{SO}_{2}$

4.9 Average Thickness Loss Rates of Representative Alloys Coated With Ash Containing 10 wt\% Alkali Sulfates and Exposed at 650 and $700^{\circ} \mathrm{C}$ for 800 Hours to Flue Gas Containing 1.0 vol\% $\mathrm{SO}_{2}$

4.10 Average Thickness Loss Rates of Representative Alloys Coated With Ash Containing 75 wt\% Alkali Sulfates and Exposed at 650 and $700^{\circ} \mathrm{C}$ for 800 Hours to Flue Gas Containing 0.25 vol\% $\mathrm{SO}_{2}$

4.11 Average Thickness Loss Rates of Representative Alloys Coated With Ash Containing 10 wt\% Alkali Sulfates and Exposed at $650^{\circ} \mathrm{C}$ for 800 Hours to Flue Gas Containing Either 0.25 or $1.0 \mathrm{V0} \% \mathrm{SO}_{2}$

4.12 Average Thickness Loss Rates of Representative Alloys Coated With Ash Containing 10 wt\% Alkali Sulfates and Exposed at $700^{\circ} \mathrm{C}$ for 800 Hours to Flue Gas Containing Either 0.25 or $1.0 \mathrm{Vol}^{\mathrm{S} \mathrm{SO}_{2}}$

4.13 Average Thickness Loss Rates of Representative Alloys Coated With Ash Containing Either 10 or 75 wt\% Alkali Sulfates and Exposed at $650^{\circ} \mathrm{C}$ for 800 or 200 Hours Respectively to Flue Gas Containing 0.25 vol\% $\mathrm{SO}_{2}$

4.14 Average Thickness Loss Rates of Representative Alloys Coated With Ash Containing Either 10 or 75 wt\% Alkali Sulfates and Exposed at $700^{\circ} \mathrm{C}$ for 800 or 200 Hours Respectively to Flue Gas Containing 0.25 vol\% $\mathrm{SO}_{2}$

4.15 Average Thickness Loss Rates of Representative Alloys Coated With Ash Containing 75 wt\% Alkali Sulfates and Exposed at $650^{\circ} \mathrm{C}$ for Either 100 or 200 Hours to Flue Gas Containing $0.25 \mathrm{vol}^{\mathrm{SO}} \mathrm{SO}_{2}$

4.16 Average Thickness Loss Rates of Representative Alloys Coated With Ash Containing 75 wt\% Alkali Sulfates and Exposed at $700^{\circ} \mathrm{C}$ for Either 100 or 200 Hours to Flue Gas Containing $0.25 \mathrm{vol}_{\mathrm{SO}} \mathrm{SO}_{2}$

4.17 Average Thickness Loss Rates of Representative Alloys Coated With Ash Containing 10 wt\% Alkali Sulfates and Exposed at $650^{\circ} \mathrm{C}$ for Either 100 or 800 Hours to Flue Gas Containing $1.0 \mathrm{Vol \%} \mathrm{SO}_{2}$ 
Figures (Cont)

Number

Page

4.18 Average Thickness Loss Rates of Representative Alloys Coated With Ash Containing 10 wt\% Alkali Sulfates and Exposed at $700^{\circ} \mathrm{C}$ for Either 100 or 800 Hours to Flue Gas Containing $1.0 \mathrm{vol} \% \mathrm{SO}_{2}$

4.19 Average Thickness Loss Rates of Representative Alloys Coated With Ash Cortaining 75 wt\% Alkali Sulfates and Exposed at $650^{\circ} \mathrm{C}$ for 200 Hours to Flue Gas Containing 0.25 vol\% $\mathrm{SO}_{2}$

4.20 Average Thickness Loss Rates of Representative Alloys Coated With Ash Containing 75 wt\% Alkali Sulfates and Exposed at $700^{\circ} \mathrm{C}$ for 200 Hours to Flue Gas Containing 0.25 vol\% $\mathrm{SO}_{2}$

4.21 Average Thickness Loss Rates of Representative Alloys Coated With Ash Containing 10 wt\% Alkali Sulfates and Exposed at $650^{\circ} \mathrm{C}$ for 800 Hours to Flue Gas Containing 1.0 vol\% $\mathrm{SO}_{2}$

4.22 Average Thickness Loss Rates of Representative Alloys Coated With Ash Containing 10 wt\% Alkali Sulfates and Exposed at $700^{\circ} \mathrm{C}$ for 800 Hours to Flue Gas Containing 1.0 vol\% $\mathrm{SO}_{2}$

4.23 Summary of Average Thickness Loss Rates for Representative Alloys Coated With Ash Containing 75 wt\% Alkali Sulfates and Exposed to Flue Gas Containing 0.25 vol\% $\mathrm{SO}_{2}$

4.24 Summary of Average Thickness Loss Rates for Representative Alloys Coated With Ash Containing 10 wt\% Alkali Sulfates and Exposed to Flue Gas Containing 0.25 vol\% $\mathrm{SO}_{2}$

4.25 Summary of Average Thickness Loss Rates for Representative Alloys Coated With Ash Containing 10 wt\% Alkali Sulfates and Exposed to Flue Gas Containing 1.0 vol\% $\mathrm{SO}_{2}$

4.26 Representative Specimens After Exposure to Various Environments

4.27 Corroded Surface of a 17-14 CuMo Specimen Coated With Ash Containing 10 wt\% Alkali Sulfates After Exposure for 200 Hours at $700^{\circ} \mathrm{C}$ to Flue Gas Containing 1.0 vol \% $\mathrm{SO}_{2}$

4.28 X-Ray Map of Corroded Surface of 17-14 CuMo Specimen Coated With Ash Containing 10 wt\% Alkali Sulfates After Exposure for 200 Hours at $700^{\circ} \mathrm{C}$ to Flue Gas Containing 1.0 vol \% $\mathrm{SO}_{2}$

4.29 Corroded Surface of RA85H Specimen Coated With Ash Containing 10 wt\% Alkali Sulfates After Exposure for 200 Hours at $700^{\circ} \mathrm{C}$ to Flue Gas Containing 1.0 vol\% $\mathrm{SO}_{2}$

4.30 X-Ray Map of Corroded Surface of RA85H Specimen Coated With Ash Containing $10 \mathrm{wt} \%$ Alkali Sulfates After Exposure for 200 Hours at $700^{\circ} \mathrm{C}$ to Flue Gas Containing 1.0 vol\% $\mathrm{SO}_{2}$ 
Figures (Cont)

Number

4.31 Corroded Surface of RA85H Specimen Coated With Ash Containing 10 wt\% Alkali Sulfates After Exposure for 800 Hours at $700^{\circ} \mathrm{C}$ to Flue Gas Containing 1.0 vol\% $\mathrm{SO}_{2}$

4.32 Corroded Surface of CR35A Specimen Coated With Ash Containing 10 wt\% Alkali Sulfates After Exposure for 200 Hours at $700^{\circ} \mathrm{C}$ to Flue Gas Containing $1.0 \mathrm{vol}^{\mathrm{S}} \mathrm{SO}_{2}$

4.33 X-Ray Map of Corroded Surface of CR35A Specimen Coated With Ash Containing 10 wt\% Alkali Sulfates After Exposure for 200 Hours at $700^{\circ} \mathrm{C}$ to Flue Gas Containing 1.0 vol\% $\mathrm{SO}_{2}$

4.34 Corroded Surface of 690 Specimen Coated With Ash Containing 10 wt\% Alkali Sulfates After Exposure for 800 Hours at $700^{\circ} \mathrm{C}$ to Flue Gas Containing 1.0 vol\% $\mathrm{SO}_{2}$

4.35 Curroded Surface of 690 Specimen Coated With Ash Containing 10 wt.\% Alkali Sulfates After Exposure for 200 Hours at $700^{\circ} \mathrm{C}$ to Flue Gas Containing 1.0 vol\% $\mathrm{SO}_{2}$

4.36 X-Ray Map of Corroded Surface of 690 Specimen Coated With Ash Containing 10 wt\% Alkali Sulfates After Exposure for 200 Hours at $700^{\circ} \mathrm{C}$ to Flue Gas Containing 1.0 vol\% $\mathrm{SO}_{2}$

4.37 Corroded Surface of Iron Aluminide Specimen Containing 2 wt\% Chromium Coated With Ash Containing 10 wt\% A? kali Sulfates After Exposure for 200 Hours to Flue Gas Containing 1.0 vol\% $\mathrm{SO}_{2}$

4.38 X-Ray Map of Corroded Surface of Iron Aluminide Specimen Containing 2 wt\% Chromium Coated With An Ash Containing 10 wt\% Alkali Sulfates After Exposure for 200 Hours at $700^{\circ} \mathrm{C}$ to Flue Gas Containing 1.0 vol\% $\mathrm{SO}_{2}$

4.39 Corroded Surface of $310 \mathrm{Nb}$ Specimen After Exposure in Pulverized-Coal-Fired Boiler for 16,000 Hours

4.40 X-Ray Map of Corroded Surface of $310 \mathrm{Nb}$ Specimen After Exposure for 16,000 Hours in Pulverized-Coal-Fired Boiler

4.41 Intergranular Attack on Corroded Surface of $690 \mathrm{Cladding;}$ Type 316 Base Metal Coated With 10 wt\% Alkali Sulfates After Exposure for 800 Hours at $700^{\circ} \mathrm{C}$ to 0.25 vol\% $\mathrm{SO}_{2}$

4.42 Chromium Depletion and General Sulfidation/Oxidation Below Layer of Scale on Corroded Surface of 690 Cladding/ Type 316 Base Metal Coated With 10 wt\% Alkali Sulfates After Exposure for 800 Hours at $700^{\circ} \mathrm{C}$ to 0.25 vol\% $\mathrm{SO}_{2}$

4.43 Corroded Surface of 72 Weld Wire/Incoloy 800 Base Metal Coated With 10 wt\% Alkali Sulfates After Exposure for 800 Hours at $700^{\circ} \mathrm{C}$ to 0.25 vol\% $\mathrm{SO}_{2}$ 


\section{Section 1}

\section{INTRODUCTION}

Liquid alkali-iron trisulfate attack has been a serious obstacle to raising steam temperatures above $538^{\circ} \mathrm{C}\left(1000^{\circ} \mathrm{F}\right)$ in boilers fired by coals with moderate to high sulfur and alkali contents. The reasons for evaluating new alloys to resist trisulfate attack include:

- Higher coal costs, making supercritical boilers economically attractive

- Diminishing reserves of low-sulfur coal, forcing utilities to burn the larger reserves of moderate- to high-suifur coal.

- Single-alloy tubing, which can provide adequate corrosion resistance, may become prohibitively expensive as the cost of chromium increases and operating environments become more demanding. Claddings and new lower-chromium alloys could provide an economical alternative to more traditional high (single)-alloy tubes.

This research was sponsored by the U.S. Department of Energy, Fossil Energy AR\&TD Materials Program, DOE/FE AA 151010 0, Work Breakdown Structure EIement FW-2. The objectives of this testing program were: to evaluate the resistance of several promising alloys to alkali-iron trisulfate (AIT) attack in various environments, to characterize the resultant corrosion morphologies, and to determine the corrosion mechanisms of these alloys. Alloys and claddings chosen for testing consisted of:

- Recently.déveloped commercial alloys containing between 20- and 35-percent chromium

- Commercial alloys modified to improve creep strength and corrosion resistance (i.e., Type 316 Mod.)

- Lean stainless steels clad with high-chromium alloys

- Intermetallic aluminides.

Selected commercial alloys widely used in pulverized-coal-fired (PC-fired) boilers provided references against which the corrosion resistances of the new alloys could be gauged. Testing was conducted at 650 and $700^{\circ} \mathrm{C}$ with synthetic ashes containing 10 wt\% and 75 wt\% alkali sulfates under three different conditions--an ash containing 75 wt\% alkali sulfates and a flue gas containing 0.25 vol\% $\mathrm{SO}_{2}$, an ash containing 10 wt\% alkali sulfates and a flue gas containing 0.25 vol\% $\mathrm{SO}_{2}$, and an ash containing 10 wt\% alkali sultates and a flue gas containing 1.0 vol\% $\mathrm{SO}_{2}$. These conditions were designed to simulate the environment found in the superheater section of an advanced PC-fired boiler burning different grades of coal. The temperatures were chosen to be representative of the skin temperature of a tube under a layer of ash and to provide conditions corrosive enough to allow us to gather meaningful test data in a short time period. This work has been patterned after previous work by Rehn and Kihara [1-4]. Procedures and alloy selection in this program have been extensively verified in reports by Rehn $[\underline{1}-\underline{3}]$. 
Section 2

EXPERIMENTAL APPROACH AND TEST PLAN

\subsection{SIMULATING BOILER CONDITIONS IN THE LABORATORY}

To simulate conditions within a boiler for the purpose of corrosion testing, alloy coupons were coated with a synthetic coal ash, placed in a sealed retort, and heated to the testing temperature $\left(650\right.$ or $\left.700^{\circ} \mathrm{C}\right)$ while a simulated flue gas was passed through the retort and over the coupons.

\subsubsection{Simulated Flue Gas Creation}

Simulated flue gases were continuously blended from cylinder gases. Figure 2.1 schematically illustrates the gas train used to create the gas mixtures. Nitrogen, carbon dioxide, and air were metered through rotometers into a common manifold. After the gas mixture passed through a water bubbler, $\mathrm{SO}_{2}$ was added to the gas stream, and the gas was sent into the experimental retorts. Tubing after the water bubbler was heated to prevent the condensation of sulfuric acid in the system.

Simulated flue gases were composed of 3.6 vol\% $\mathrm{O}_{2}, 14.0$ vol\% $\mathrm{CO}_{2}$, 10.0 vol\% $\mathrm{H}_{2} \mathrm{O}$, and either 0.25 or 1.0 vol\% $\mathrm{SO}_{2}$, with the balance $\mathrm{N}_{2}$. The $\mathrm{O}_{2}$, $\mathrm{CO}_{2}$, and $\mathrm{SO}_{2}$ levels in the gas stream were determined by analyzing samples taken from the gas inlet of the retort.

\subsubsection{Syntheric Fuel Ash Preparation}

Three synthetic ashes were used in this program; their compositions are listed in Table 2.1. Ash Compositions 1 and 2 were used during the initial testing; however, Ash Composition 1 was too corrosive for the length of the planned tests. A less-corrosive ash, which would be more representative of ashes found in PC-fired boilers, was chosen for all later tests (Ash 3).

Table 2.1 Ash Compositions (wt\%)

Ash 1

$25 \mathrm{Fe}_{2} \mathrm{O}_{3}$

$37.5 \mathrm{Na}_{2} \mathrm{SO}_{4}$

$37.5 \mathrm{~K}_{2} \mathrm{SO}_{4}$

\begin{tabular}{crr}
\multicolumn{1}{c}{ Ash 2 } & & Ash 3 \\
\cline { 1 - 1 } $9 \mathrm{Fe}_{2} \mathrm{O}_{3}$ & & $30 \mathrm{Fe}_{2} \mathrm{O}_{3}$ \\
$5 \mathrm{Na}_{2} \mathrm{SO}_{4}$ & & $5 \mathrm{Na}_{2} \mathrm{SO}_{4}$ \\
$5 \mathrm{~K}_{2} \mathrm{SO}_{4}$ & $5 \mathrm{~K}_{2} \mathrm{SO}_{4}$ \\
& $30 \mathrm{Al}_{2} \mathrm{O}_{3}$ \\
& $30 \mathrm{SiO}_{2}$
\end{tabular}




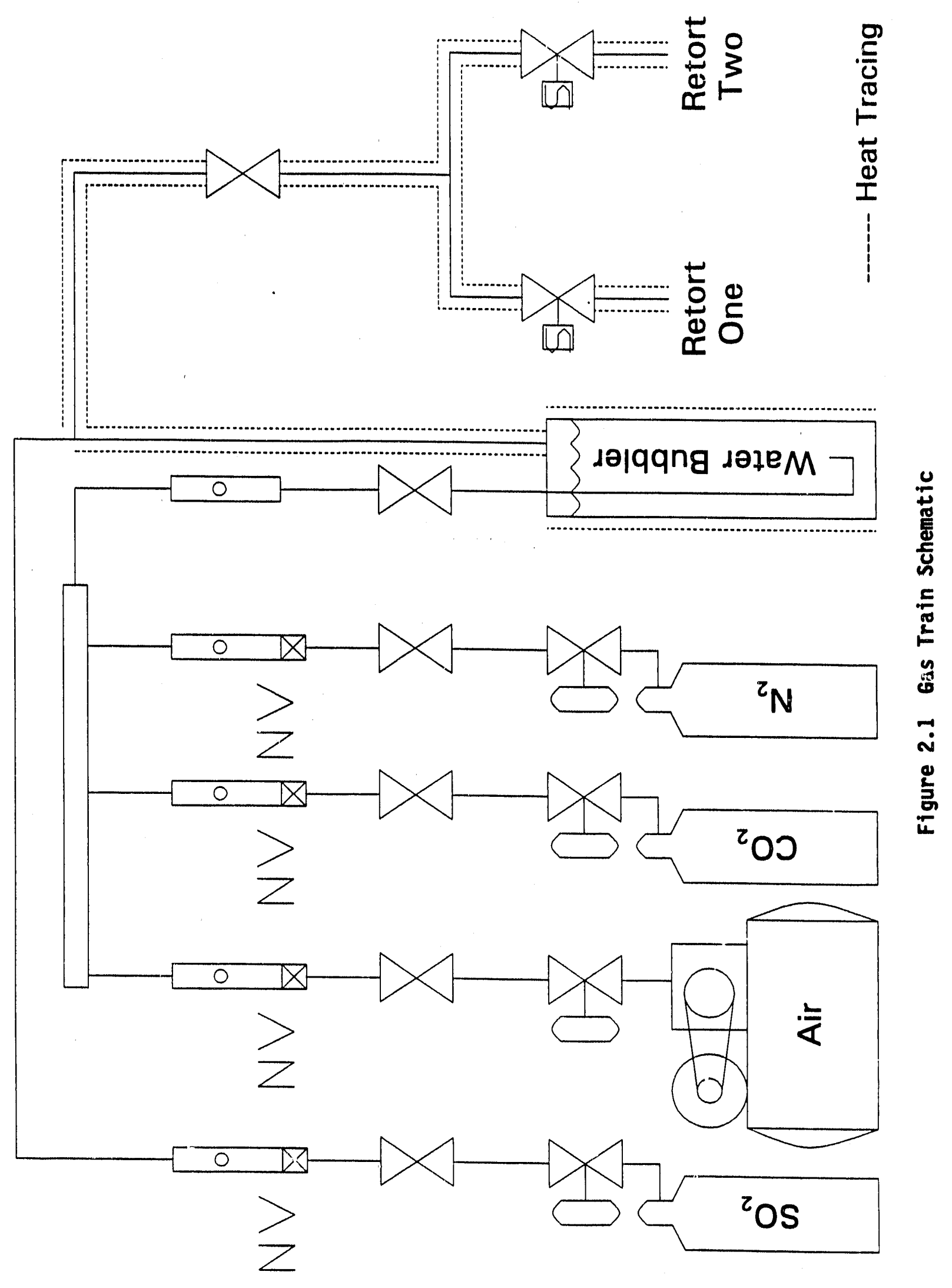


To prepare an ash, reagent-grade chemicals listed in Table 2.1 were ground in a ball mill and sieved through a 325-mesh screen. After screening, the powders were measured and blended to form a synthetic ash. The ash was milled for 24 hours to further grind and $\mathrm{mix}$ the component powders.

\subsubsection{Furnare and Experimental Retort}

The retorts for this project were similar to the retorts used in earlier fireside corrosion studies by Rehn [1]. Figure 2.2 illustrates a side view of a retort. Simulated flue gas was passed from the inlet, through iron turnings placed to catalyze $\mathrm{SO}_{2}$ to $\mathrm{SO}_{3}$, over the specimens, and out the exhaust tubes. Thermowells in the retorts monitored interior temperatures during the experiments.

\subsection{MATERIALS SELECTION}

Alloys and claddings that appeared to have promising resistance to AIT attack, along with alloys considered as industry standards, were selected for examination. The coupons for these tests were 1 in. $x 2$ in. Three or four coupons were placed in each tube of the retort. The alloys and claddings selected for testing, with their chemical compositions, are listed in Table 2.2.

\subsection{OVERVIEW OF TESTING SEQUENCE}

The experimental technique used in this project follows work conducted earlier by Rehn [1]. Coupons were stamped and weighed; their thicknesses were then measured. The top surface of the coupons was coated with a synthetic ash and they were exposed to simulated flue gas at elevated temperatures. After exposure the coupons were either evaluated, re-coated with synthetic ash, or steam cleaned and recoated with synthetic ash.

Three series of tests were conducted, each test exposure being run in parallel at both 650 and $700^{\circ} \mathrm{C}$. Table 2.3 summarizes the exposure conditions for each series of tests. Test Series 1 was conducted for 100 and 200 hours with a high-sulfate ash in a gas containing 0.25 vol\% $\mathrm{SO}_{2}$. Test Series 2 was conducted for 100 and 800 hours with a low-sulfate ash in a gas containing 0.25 vol\% $\mathrm{SO}_{2}$. Test Series 3 was conducted for 100 and 800 hours with a lowsulfate ash in a gas containing 1.0 vol\% $\mathrm{SO}_{2}$.

To determine the effects of steam cleaning on corrosion rates, duplicate sets of coupons were tested for exposures longer than one 100-hour cycle. The ash layer on one set of coupons was replenished between exposures. The ash was steam cleaned from the second set of coupons, and the coupons were recoated with new ash between exposures.

\subsubsection{Inttial Characterization of Coupons}

All alloys with the exception of CR35A were received in coupon form; Alloy CR35A was received in plate form and machined to size. Clad materials were analyzed by $x$-ray spectroscopy to determine which surface was the 


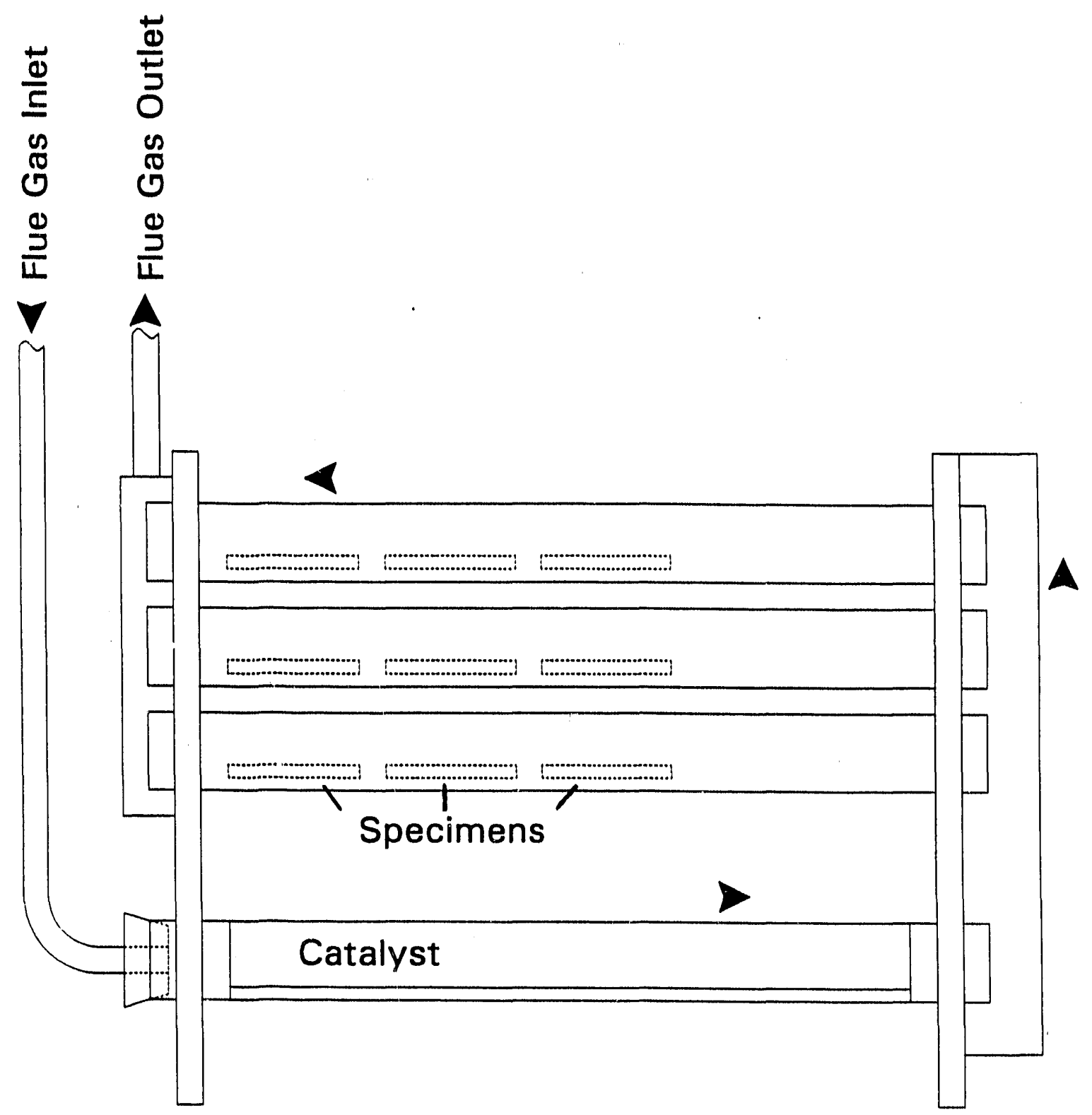

Figure 2.2 Furnace Experimental Retort 


\begin{tabular}{|c|c|c|c|c|c|c|c|c|c|c|c|c|c|c|c|c|c|c|c|c|c|}
\hline 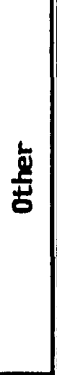 & $\begin{array}{l}\overrightarrow{0} \\
0 \\
\infty\end{array}$ & & & 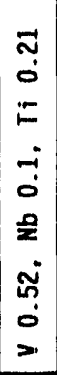 & $\begin{array}{l}\text { m. } \\
\dot{m} \\
\dot{3}\end{array}$ & \begin{tabular}{|l|}
$\infty$ \\
0 \\
0 \\
0 \\
$\underline{\alpha}$ \\
2
\end{tabular} & \begin{tabular}{|l|}
0 \\
0 \\
0 \\
3 \\
3
\end{tabular} & $\begin{array}{c}f \\
0 \\
0 \\
> \\
0 \\
2 \\
0 \\
5 \\
F \\
0 \\
0 \\
0 \\
0 \\
0 \\
2\end{array}$ & $\begin{array}{l}0 \\
0 \\
1 \\
1 \\
0 \\
0 \\
0 \\
\mathbf{z}\end{array}$ & 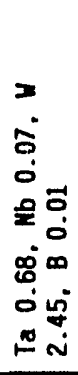 & $\begin{array}{l}\text { L8 } \\
0 \\
0 \\
2\end{array}$ & & & & & & & 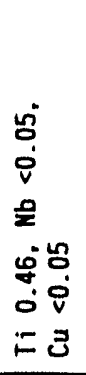 & $\begin{array}{l}n \\
\tilde{n} \\
0 \\
\tilde{F}\end{array}$ & $\begin{array}{l}8 \\
\\
\\
\end{array}$ & \\
\hline$=$ & & & & $\begin{array}{l}\hat{o} \\
0 \\
0\end{array}$ & 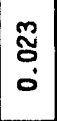 & \begin{tabular}{|l|} 
\\
0 \\
0 \\
0 \\
0
\end{tabular} & 足 & $\begin{array}{l}0 \\
0 \\
0 \\
0\end{array}$ & $\begin{array}{l}\tilde{o} \\
0 \\
\dot{v}\end{array}$ & $\begin{array}{l}\stackrel{0}{0} \\
0 \\
0\end{array}$ & $\stackrel{m}{0}$ & $\begin{array}{l}\text { no } \\
0 \\
\dot{0}\end{array}$ & 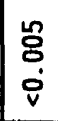 & & & & $\begin{array}{l}0 \\
0 \\
0\end{array}$ & $\begin{array}{l}\tilde{0} \\
0 \\
0\end{array}$ & & $\begin{array}{l}\text { d } \\
\dot{0} \\
\dot{0}\end{array}$ & \\
\hline n & & & & $\begin{array}{l}\dot{0} \\
\dot{0}\end{array}$ & 枵 & 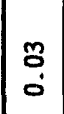 & & $\mid \begin{array}{l}0 \\
0 \\
0 \\
0\end{array}$ & $\begin{array}{l}\overrightarrow{0} \\
\dot{0}\end{array}$ & $\begin{array}{l}\tilde{\delta} \\
0\end{array}$ & $\begin{array}{l}\bar{\delta} \\
\text { ठ̊ } \\
0\end{array}$ & $\begin{array}{l}\tilde{\Xi} \\
\vdots \\
0\end{array}$ & 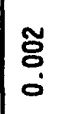 & & & $\begin{array}{l}\vec{\vdots} \\
0 \\
0\end{array}$ & 安 & o̊ & & $\begin{array}{l}0 \\
0 \\
0\end{array}$ & \\
\hline$=$ & & & & $\begin{array}{l}\cong \\
0 \\
0\end{array}$ & & & 움 & $\begin{array}{l}0 \\
0 \\
0 \\
\end{array}$ & 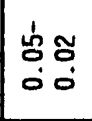 & $\stackrel{0}{0}$ & $\stackrel{\mathscr{m}}{\mathfrak{0}}$ & & & & & & & $\begin{array}{l}\text { 号 } \\
\text { O } \\
0\end{array}$ & & 号 & \\
\hline $\bar{z}$ & $\begin{array}{l}\stackrel{m}{9} \\
\stackrel{n}{n}\end{array}$ & $\stackrel{9}{\Omega}$ & $\stackrel{\circ}{=}$ & $\left\{\begin{array}{l}0 \\
0 \\
0\end{array}\right.$ & & & $\stackrel{8}{\stackrel{8}{0}}$ & $\begin{array}{l}\tilde{0} \\
0 \\
0\end{array}$ & & $\stackrel{m}{-1}$ & & & & & & & & $\begin{array}{l}\text { o } \\
\dot{i}\end{array}$ & & & $\begin{array}{l}\bar{m} \\
\stackrel{\Xi}{\mathrm{g}}\end{array}$ \\
\hline E & & & & 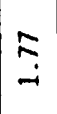 & $\begin{array}{l}\infty \\
\infty \\
0 \\
0\end{array}$ & $\begin{array}{l}0 \\
-i\end{array}$ & 号 & $\stackrel{9}{\stackrel{9}{-}}$ & $\stackrel{n}{\vec{v}}$ & $\begin{array}{l}\text { 告 } \\
\text { ○े }\end{array}$ & 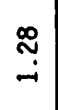 & $\begin{array}{l}a \\
0\end{array}$ & च & & $\dddot{0}$ & $\begin{array}{l}0 \\
0 \\
0\end{array}$ & 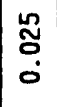 & $\frac{0}{0}$ & & $\begin{array}{l}0 \\
0 \\
0\end{array}$ & कon \\
\hline $\bar{n}$ & & & & $\stackrel{\mathscr{2}}{\stackrel{2}{0}}$ & $\stackrel{\sim}{\sim}$ & $\stackrel{m}{-}$ & 品 & 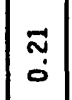 & $\hat{o}$ & $\stackrel{+}{\circ}$ & $\underset{\Im}{*}$ & $\stackrel{\mathscr{N}}{\stackrel{0}{0}}$ & $\stackrel{2}{\text { Oִ }}$ & & & $\begin{array}{l}0 \\
0 \\
0\end{array}$ & $\stackrel{n}{0}$ & $\overrightarrow{0}$ & & $\stackrel{n}{0}$ & \\
\hline ט & & & & $\begin{array}{l}0 \\
0 \\
0 \\
0\end{array}$ & $\begin{array}{l}\infty \\
0 \\
0\end{array}$ & $\begin{array}{l}0 \\
0 \\
0 \\
0\end{array}$ & 竎 & $\begin{array}{l}\text { sa } \\
\text { d }\end{array}$ & $\tilde{i}$ & $\overrightarrow{0}$ & $\begin{array}{l}\mathscr{0} \\
\dot{0} \\
\dot{0}\end{array}$ & \begin{tabular}{l}
$\infty$ \\
\multirow{0}{0}{} \\
$\vdots$ \\
0
\end{tabular} & $\begin{array}{l}\text { go } \\
0 \\
0\end{array}$ & 罗 & & $\begin{array}{l}a \\
0 \\
0\end{array}$ & $\begin{array}{l}\vec{\sigma} \\
0 \\
0\end{array}$ & $\begin{array}{l}5 \\
0 \\
0\end{array}$ & 告 & 辛 & $\begin{array}{l}\text { \& } \\
\text { a' } \\
\text { ¿ }\end{array}$ \\
\hline q & & & & $\stackrel{\sim}{\sim}$ & $\stackrel{\leftrightarrow}{\leftrightarrow}$ & & $\begin{array}{l}0 \\
0 \\
0\end{array}$ & $\overrightarrow{\tilde{a}}$ & bo & $\stackrel{\substack{\infty \\
\infty \\
\sim}}{\sim}$ & & $\begin{array}{l}\text { ug } \\
\dot{v} \\
\dot{v}\end{array}$ & $\begin{array}{l}\text { us } \\
\dot{0}\end{array}$ & & & & 鸟 & 亗 & & $\stackrel{\mathscr{m}}{m}$ & 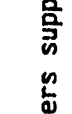 \\
\hline s & $\stackrel{9}{\stackrel{\sim}{\sim}}$ & $\begin{array}{l}\infty \\
\dot{\omega}\end{array}$ & $\stackrel{\sim}{\sim}$ & $\begin{array}{l}\tilde{a} \\
\vdots \\
\sim\end{array}$ & $\begin{array}{l}\tilde{m} \\
\stackrel{0}{\sigma}\end{array}$ & $\begin{array}{l}n \\
\\
=\end{array}$ & 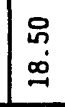 & $\begin{array}{l}\infty \\
\infty \\
\dot{N}\end{array}$ & $\frac{n}{2}$ & $\stackrel{\sim}{\sim}$ & $\begin{array}{l}\mathscr{2} \\
\vdots \\
\dot{\alpha}\end{array}$ & 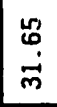 & in & 品 & 泜 & $\mid \begin{array}{l}m \\
\stackrel{p}{p} \\
\dot{p}\end{array}$ & $\begin{array}{l}8 \\
\dot{m} \\
\dot{m}\end{array}$ & $\begin{array}{c}n \\
\infty \\
\infty \\
\sigma\end{array}$ & $\mid \begin{array}{c}0 \\
\dot{q}\end{array}$ & 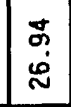 & $=$ \\
\hline 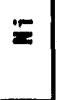 & & & $\vec{i}$ & 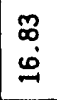 & $\begin{array}{l}\mathscr{8} \\
\dot{\square} \\
\end{array}$ & $\begin{array}{l}m \\
\stackrel{0}{g}\end{array}$ & 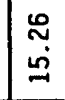 & $\begin{array}{c}\infty \\
\dot{m} \\
\dot{m}\end{array}$ & m & $\vec{\sim}$ & $\begin{array}{l}\text { f } \\
\dot{2}\end{array}$ & m. & m. & $\bar{\infty}$ & $\mid \begin{array}{l}\infty \\
\dot{g} \\
\dot{y}\end{array}$ & 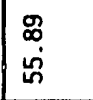 & m & $\bar{\infty}$ & $\bar{\infty}$ & $\frac{9}{\stackrel{9}{-1}}$ & a \\
\hline W & $\begin{array}{l}\infty \\
\infty \\
\dot{\infty}\end{array}$ & $\stackrel{n}{\sim}$ & 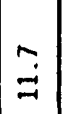 & $\bar{\infty}$ & $\bar{\infty}$ & $\bar{\infty}$ & $\bar{\infty}$ & $\bar{\infty}$ & $\bar{\infty}$ & $\bar{w}$ & $\bar{\infty}$ & $\begin{array}{l}\text { g } \\
\text { के }\end{array}$ & $\stackrel{m}{\sigma}$ & n? & $\cong$ & $\begin{array}{l}\hat{N} \\
0\end{array}$ & 出 & & & $\bar{\infty}$ & 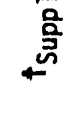 \\
\hline$\frac{\grave{\partial}}{\bar{z}}$ & 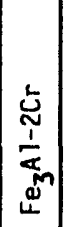 & 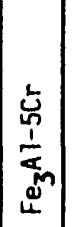 & 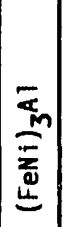 & 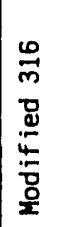 & $\begin{array}{l}\frac{0}{3} \\
\frac{3}{3} \\
\frac{1}{1} \\
\frac{1}{7}\end{array}$ & 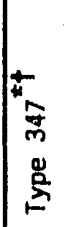 & $\begin{array}{l}\text { 忈 } \\
\text { 要 }\end{array}$ & 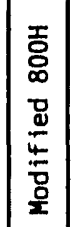 & t. & 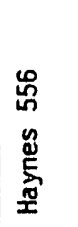 & t. & 䁶 & $\begin{array}{l}\text { 동 } \\
\text { 용 } \\
\text { 용 }\end{array}$ & " & +r & 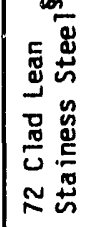 & 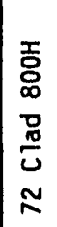 & 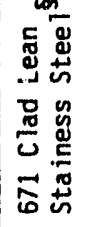 & . & 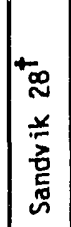 & $\frac{\dot{0}}{\stackrel{0}{2}}$ \\
\hline
\end{tabular}




\section{Table 2.3 Test Exposure Conditions}

\section{Test 1 Test 2 Test 3}

Testing Time

100 hours

200 hours

800 hours

Ash Composition

Ash 1

Ash 2

Ash 3

$\begin{array}{lll}x & x & x \\ x & x & x\end{array}$

$x$

$x$

$x$

Gas Composition

LoW $\mathrm{SO}_{2}$

High $\mathrm{SO}_{2}$

$x$

$x$

cladding. Identifying markings were stamped on the coupons, the coupons were weighed, and their thickness was measured at each corner and at the center.

\subsubsection{Preparing Coupons Before Exposure}

The following was done to simulate a layer of coal ash on the test coupons: A binder of ethanol saturated with camphor was mixed with the synthetic coal ash to form a paste. This paste was spread over the top of the coupons to form a uniform layer of ash weighing approximately $1 \mathrm{~g} / \mathrm{in}^{2}$. (Rehn [1] found that a coating thinner than $40 \mathrm{mg} / \mathrm{in}^{2}$ limited corrosive weight loss for a 100-hour testing period, while thicker coatings contained ample reactants for the entire testing period.) After coating, coupons were loaded into the retort; care was taken to ensure that the coupons were set in a horizontal position in the tubes of the retort.

\subsubsection{Exposing Specinens to a Simulated Boller Environment}

After a retort was loaded, sealed, and lowered into a box furnace, a nitrogen purge was started, and the retort was brought to temperature. As the retort was heating, the camphor binder was driven off and carried out with the nitrogen. When the retort reached operating temperature, ihe nitrogen purge gas was stopped, and simulated flue gas was passed through the retort. At the end of the 100-hour exposure, the furnace was turned of $f$ to cool, and a nitrogen purge was started.

\subsubsection{Post-Exposure Steam Cleaning and Recoating}

After exposure the specimens were sorted into two groups. One group of specimens was recoated with fresh coal ash over the previous ash, while the second group of specimens was steam cleaned and recoated with fresh ash. The specimens were steam cleaned by holding them under a spray of saturated steam. 


\subsubsection{Weight Loss, Thickness Loss, and Pit Depth Measurements}

All descaled specimens were weighed and measured for average and maximum thickness loss. Specimen weights were measured on a Sartorius 1202MP electronic scale; thicknesses were measured with Mitutoyo digital micrometers. Average thickness losses were determined by taking measurements at the corners and in the middle of a specimen before and after exposure to the simulated boiler environment, then subtracting the averaged preexposure measurements from the post-exposure measurements. Maximum thickness loss was determined by measuring the thinnest area of a specimen after exposure and subtracting it from the preexposure average.

\subsubsection{Microscopic Examination and Chemical Analysis}

To study the mechanisms of attack, selected specimens were sectioned and examined using optical and electron microscopy. Specimens to be examined were sectioned, mounted in Bakelite, ground (with water as a lubricant), and polished. After preparation the mounted specimens were examined with both an optical measurescope (to determine scale thickness and morphological features) and an EXEC Autoscan electron microscope with an EDAX 9800 energy dispersive $x$-ray unit (to examine fine features and to analyze chemical makeup). 


\section{Section 3}

\section{RESULTS OF FIRESIDE TESTING}

This section summarizes all relevant weight and thickness loss data from the experimental portion of the program. Data are given primarily in graphic format to allow easily drawn comparisons between alloys. Corrosion rate data presented in this section are intended for comparing the corrosion resistance of various alloys--not as design data. Appendix $A$ contains photographs of the exposed specimens that illustrate the morphology of attack.

Several cautions are appropriate when reviewing the graphs and tables presented in this section:

- Weight loss and thickness loss measurements on the pack cementation-coated specimens from Ohio State University are misleading. The specimens on which the corrosion-resistant outer layer was breached show anomalousiy high corrosion rates as a result of catastrophic corrosion of the inner core. Thus these coupons were evaluated "pass/fail", depending on whether the coating was breached.

- The $671 \mathrm{clad}$ lean stainless steel coupons had a layer of lean stainless steel remaining on the underside of the coupons. This layer lost more metal as a result of gas phase attack and descaling than the 671 layer lost from AIT attack. The losses from the 671 layer were gauged visually.

- Greater-than-expected wastage rates of several highly alloyed coupons may have been caused by the descaling procedure. The highly alloyed specimens were coated with a hard black scale that defied all but the most severe descaling methods. Consequently, some base metal may have been removed from the specimens along with the scale.

- Several aluminide specimens suffered so much wastage that accurate weight loss and thickness loss measurements were no longer possible. 
The testing program was initially conducted using a highly aggressive synthetic coal ash $\left(37.5 \mathrm{wt \%} \mathrm{Na}_{2} \mathrm{SO}_{4}, 37.5 \mathrm{wt} \% \mathrm{~K}_{2} \mathrm{SO}_{4}, 25 \mathrm{wt} \% \mathrm{Fe}_{2} \mathrm{O}_{3}\right.$ ) to provide accelerated corrosion testing. Conditions were otherwise chosen to be representative of an advanced PC-fired boller burning a medium-sulfur coal: $A$ simulated flue gas composition of 0.25 vol\% $\mathrm{SO}_{2}, 3.6$ vol\% $\mathrm{O}_{2}, 14.0$ vol\% $\mathrm{CO}_{2}$, 10.0 vol\% $\mathrm{H}_{2} \mathrm{O}, \mathrm{Bal} . \mathrm{N}_{2}$ and test temperatures of 650 and $700^{\circ} \mathrm{C}$. Materials marked with an asterisk in the graphs were coated with a less-aggressive coal ash ( $5 \mathrm{wt} \% \mathrm{Na}_{2} \mathrm{SO}_{4}, 5$ wt\% $\mathrm{K}_{2} \mathrm{SO}_{4}, 90 \mathrm{wt} \% \mathrm{Fe}_{2} \mathrm{O}_{3}$ ) as a comparison.

Two 100-hour exposures were conducted, with ash replenishment between exposures. Testing was stopped after the second 100-hour exposure because there were unacceptably high corrosion losses; the corrosion rates of several specimens were so high that complete penetration of the specimens was projected by the end of the third or fourth exposure.

\subsubsection{Weight Loss"}

Weight loss data for specimens exposed at $650^{\circ} \mathrm{C}$ are shown in Figure 3.1. Data for specimens exposed at $700^{\circ} \mathrm{C}$ are shown in Figure 3.2. All data have been normalized to $\mathrm{mg} 10 \mathrm{st} / \mathrm{cm}^{2} / 100$ hours.

\subsubsection{Thickness Losses"}

Data for average thickness losses are shown in Figures 3.3 and 3.4; maximum thickness loss data are shown in Figures 3.5 and 3.6 . All data have been normalized to mils lost/100 hours.

\footnotetext{
"Specimens are shown left to right in order of increasing chromium content. 'LSS (lean stainless steel) is Type 316 mod.
} 

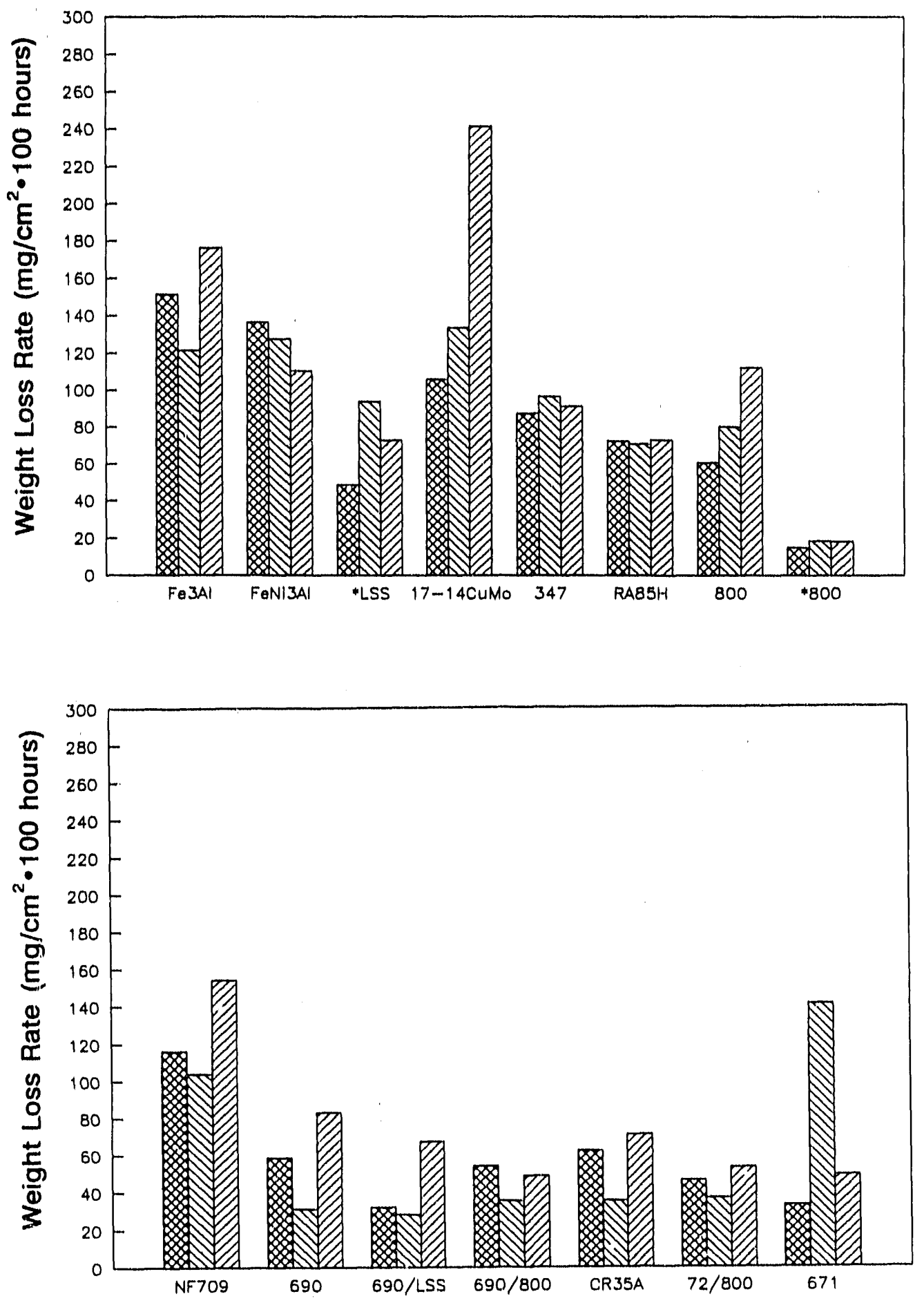

100 hours $D I T Z \begin{aligned} & 200 \text { hours } \\ & \text { (steam cleaned) hours } \\ & \text { (recoated) }\end{aligned}$

Figure 3.1 Normalized Weight Loss Rates for Alloys Coated With a 75 wt\% Alkali Sulfate Ash and Exposed at $650^{\circ} \mathrm{C}$ to a 0.25 vol\% $\mathrm{SO}_{2}$ Flue Gas 

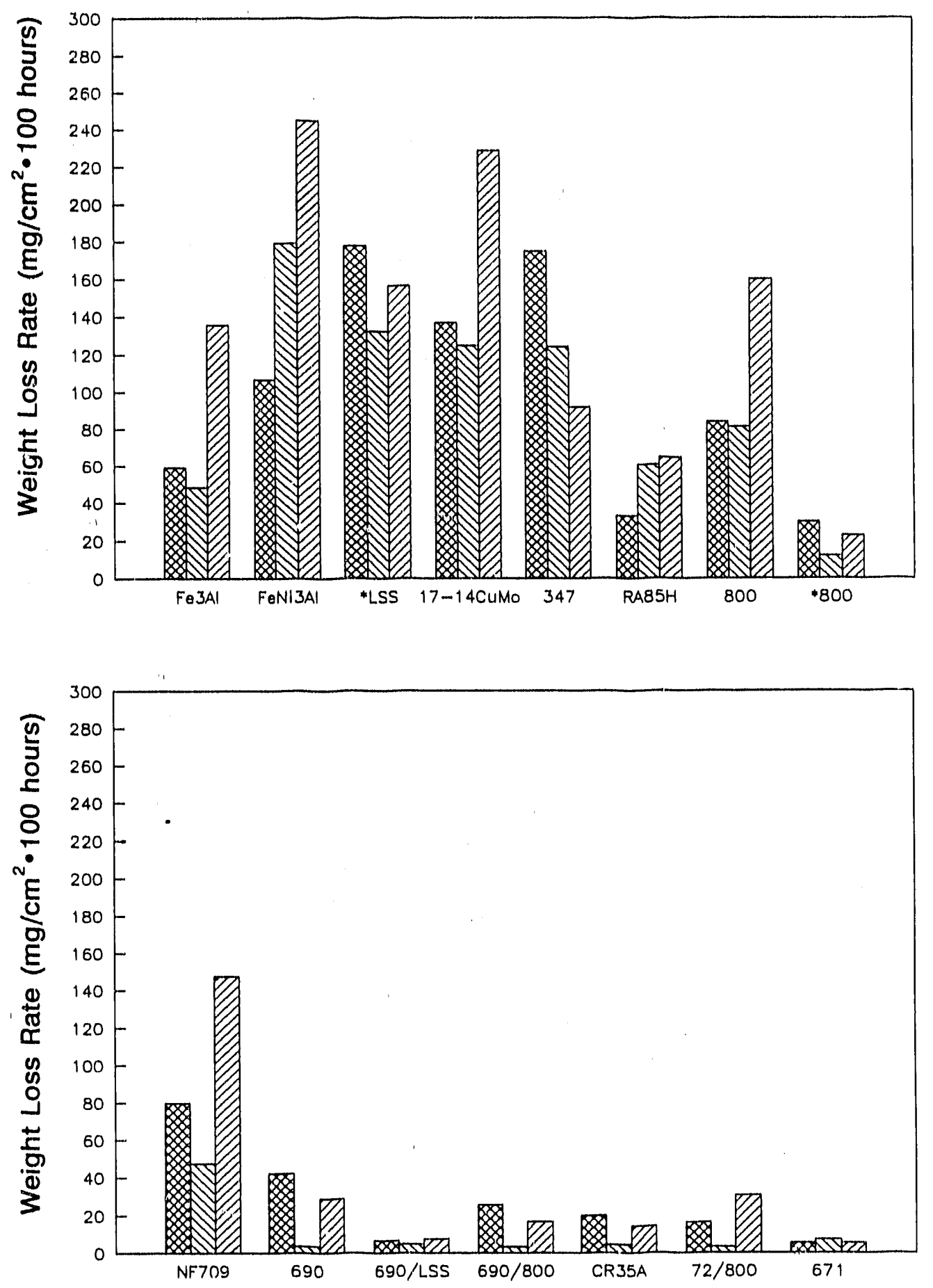

Q8X 100 hours WIVT $\begin{aligned} & 200 \text { hours } \\ & \text { (steam cleaned) } \\ & \text { (recoated) }\end{aligned}$

Figure 3.2 Normalized Weight Loss Rates for Alloys Coated With a 75 wt\% Alkali Sulfate Ash and Exposed at $700^{\circ} \mathrm{C}$ to a 0.25 vol\% $\mathrm{SO}_{2}$ Flue Gas 

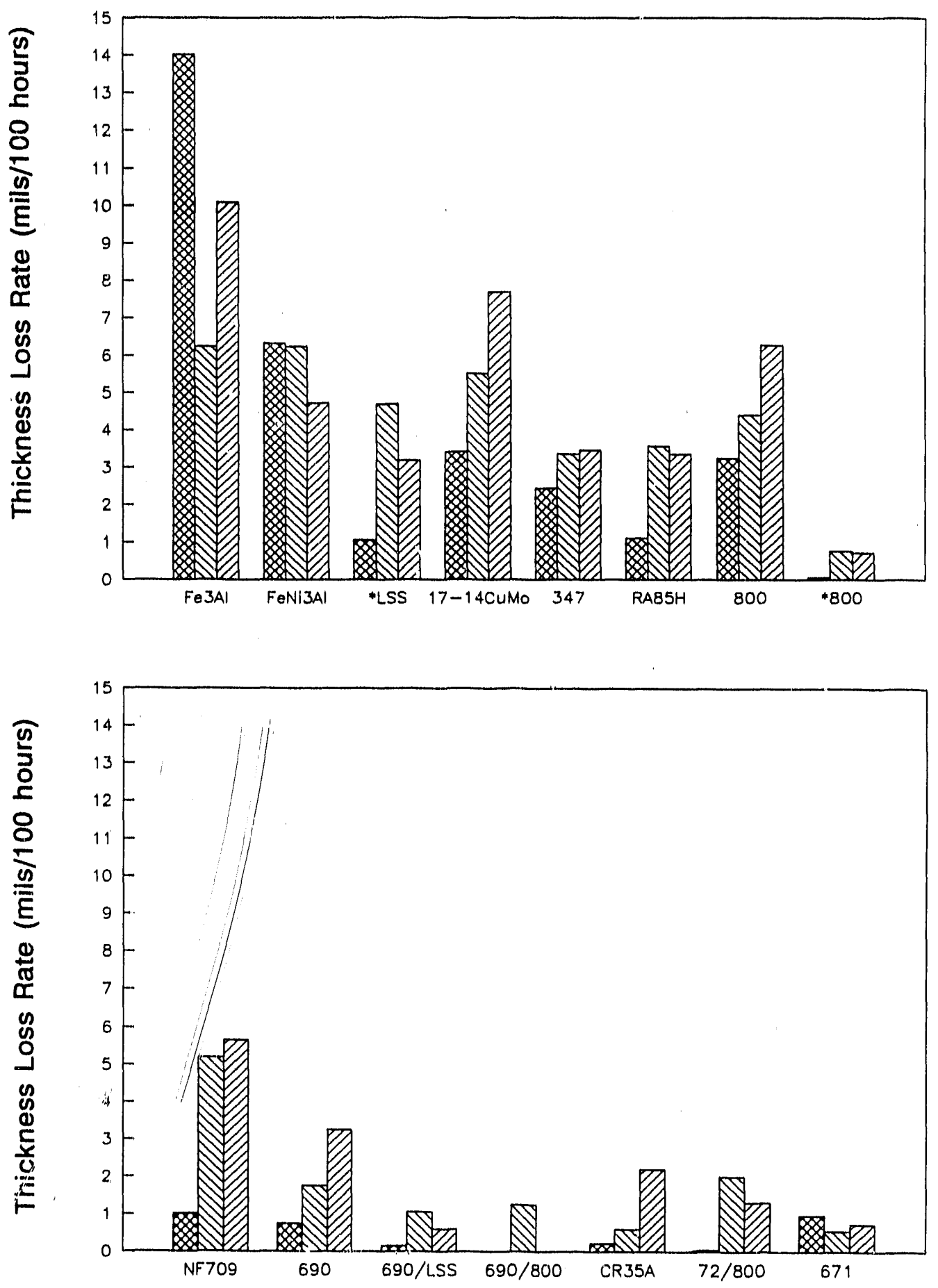

100 hours $11200 \begin{aligned} & 200 \text { hours } \\ & \text { (steam cleaned) } \\ & \text { (recoated) }\end{aligned}$

Figure 3.3 Normalized Thickness Loss Rates for Alloys Coated With a 75 wt\% Alkali Sulfate Ash and Exposed at $650^{\circ} \mathrm{C}$ to a 0.25 vol\% $\mathrm{SO}_{2}$ Flue Gas 

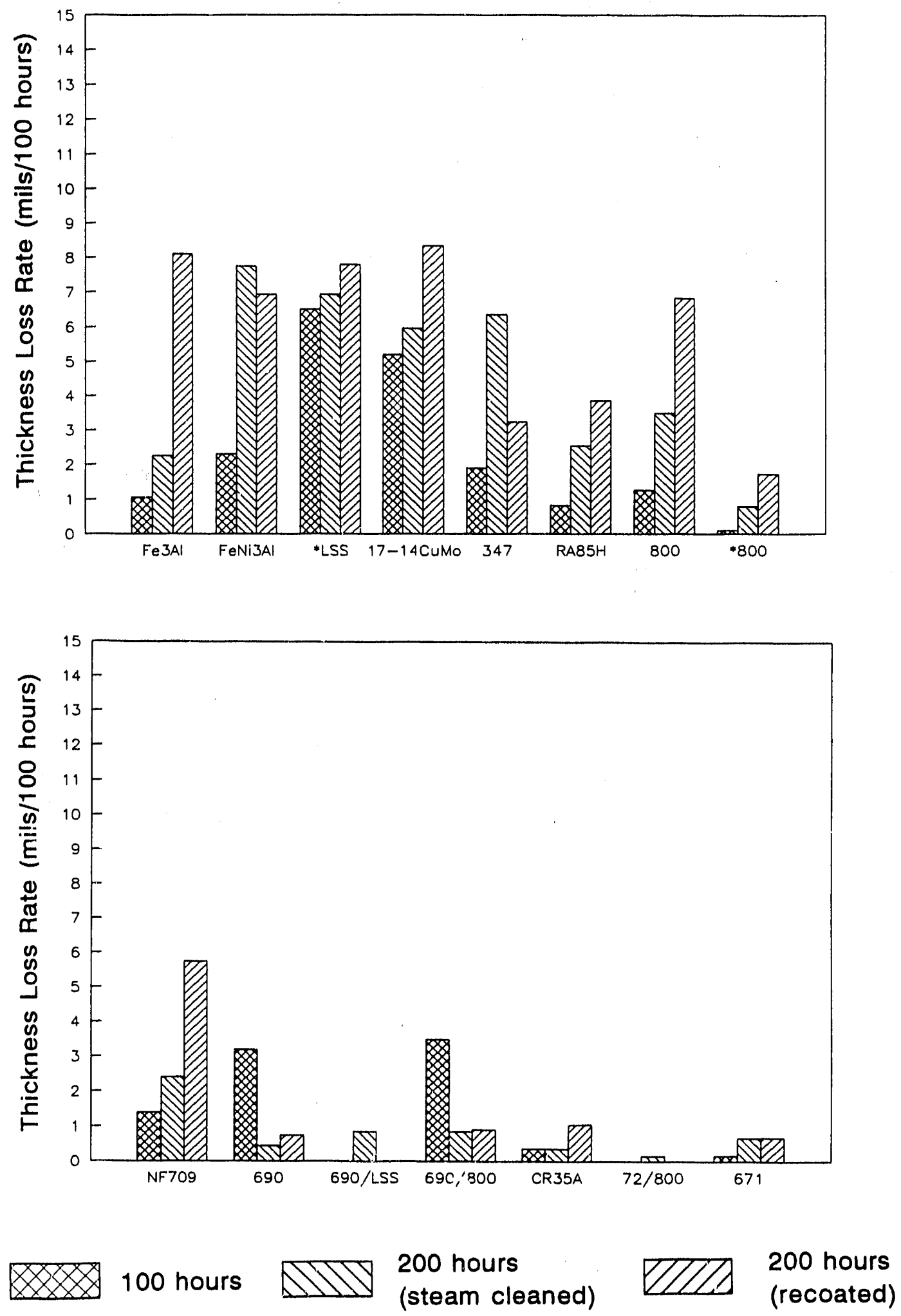

Figure 3.4 Normalized Thickness Loss Rates for Alloys Coated With a 75 wt\% Alkali Sulfate Ash and Exposed at $700^{\circ} \mathrm{C}$ to a 0.25 vol\% $\mathrm{SO}_{2}$ Flue Gas 

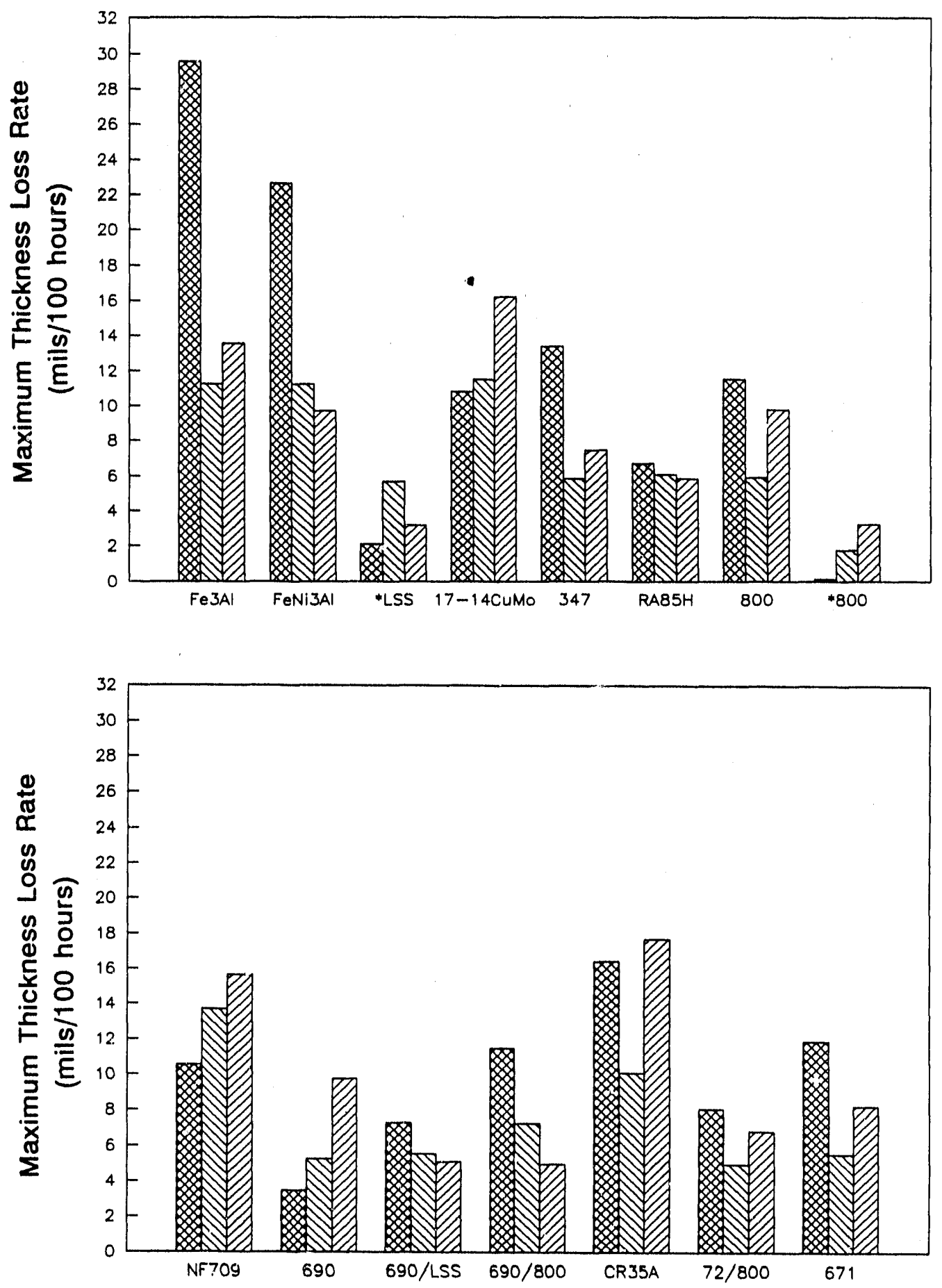

100 hours DIIIJ $\begin{aligned} & 200 \text { hours } \\ & \text { (steam cleaned) } \\ & \text { (recoated) }\end{aligned}$

Figure 3.5 Normalized Maximum Thickness Loss Rates for Alloys Coated With a 75 wt\% Alkali Sulfate Ash and Exposed at $650^{\circ} \mathrm{C}$ to a 0.25 vol\% $\mathrm{SO}_{2}$ Flue Gas 

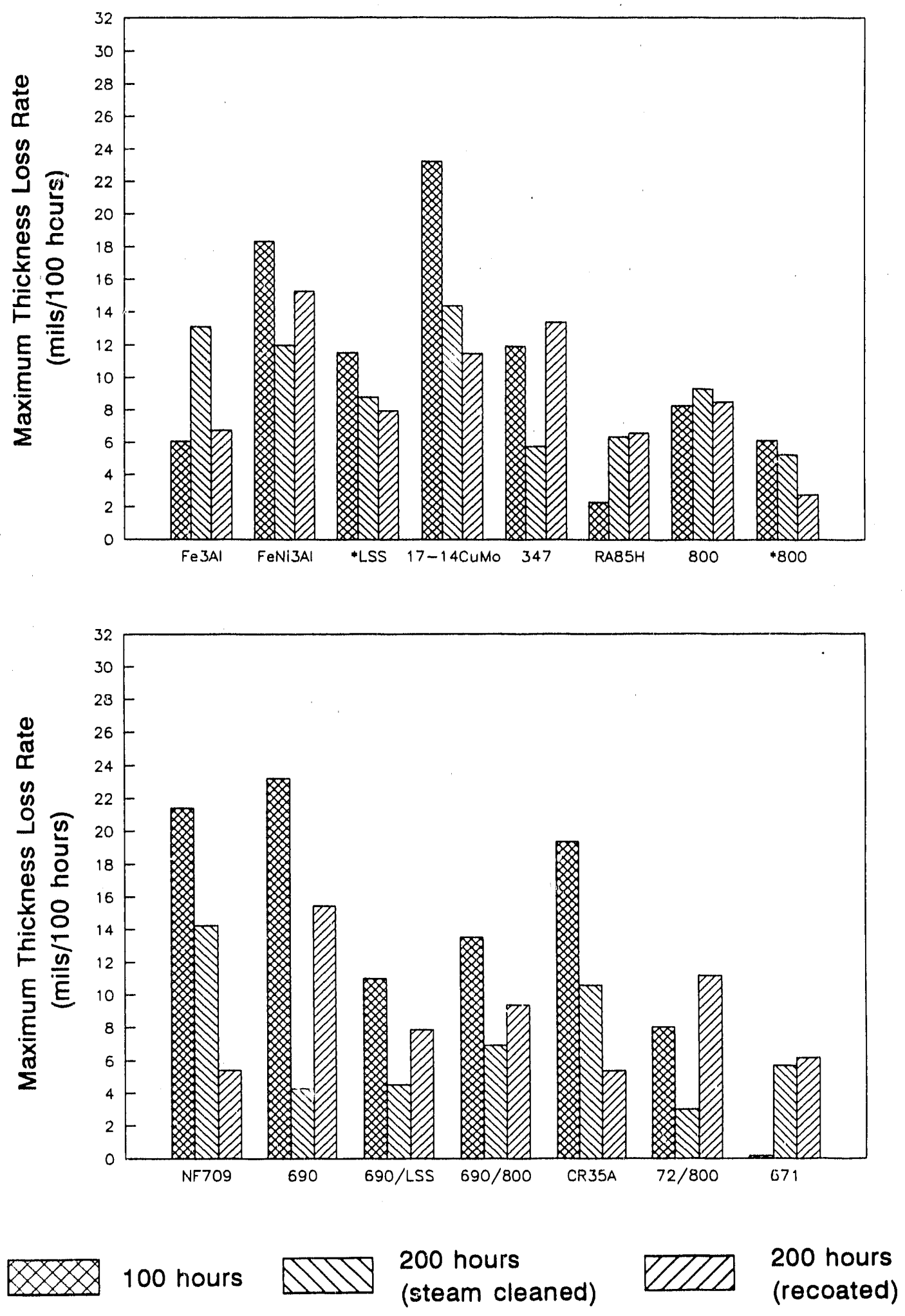

Figure 3.6 Normalized Maximum Thickness Loss Rates for Alloys Coated With a 75 wt\% Alkali Sulfate Ash and Exposed at $700^{\circ} \mathrm{C}$ to a 0.25 vol\% $\mathrm{SO}_{2}$ Flue Gas 


\subsection{RESULTS OF THE 100- AND 800-HOUR LOW-SULFATE 0.25 vol\% $\mathrm{SO}_{2}$ TESTS}

A second set of tests was conducted with a synthetic coal ash similar in composition to ashes found in PC-fired boilers ( 5 wt\% $\mathrm{Na}_{2} \mathrm{SO}_{4}, 5$ wt\% $\mathrm{K}_{2} \mathrm{SO}_{4}$, $30 \mathrm{wt} \% \mathrm{Fe}_{2} \mathrm{O}_{3}, 30 \mathrm{wt} \% \mathrm{Al}_{2} \mathrm{O}_{3}, 30 \mathrm{wt} \% \mathrm{SiO}_{2}$ ). The simulated flue gas (composition: 0.25 vol\% $\mathrm{SO}_{2}, 3.6$ vol\% $\mathrm{O}_{2}, 14.0$ vol\% $\mathrm{CO}_{2}, 10.0$ vol\% $\mathrm{H}_{2} \mathrm{O}, \mathrm{Bal} . \mathrm{N}_{2}$ ) is representative of flue gases found in PC-fired boilers burning medium-sulfur coals.

\subsubsection{Weight Loss*}

Weight loss data are shown iri Figures 3.7 and 3.8. All data have been normalized to $\mathrm{mg}$ lost $/ \mathrm{cm}^{2} / 100$ hours.

\subsubsection{Thickness Losses*}

Data for average thickness losses are shown in Figures 3.9 and 3.10 ;

maximum thickness loss data are shown in Figures 3.11 and 3.12 . A11 data have been normalized to mils lost/100 hours.

"Specimens are listed in order of increasing chromium content. 

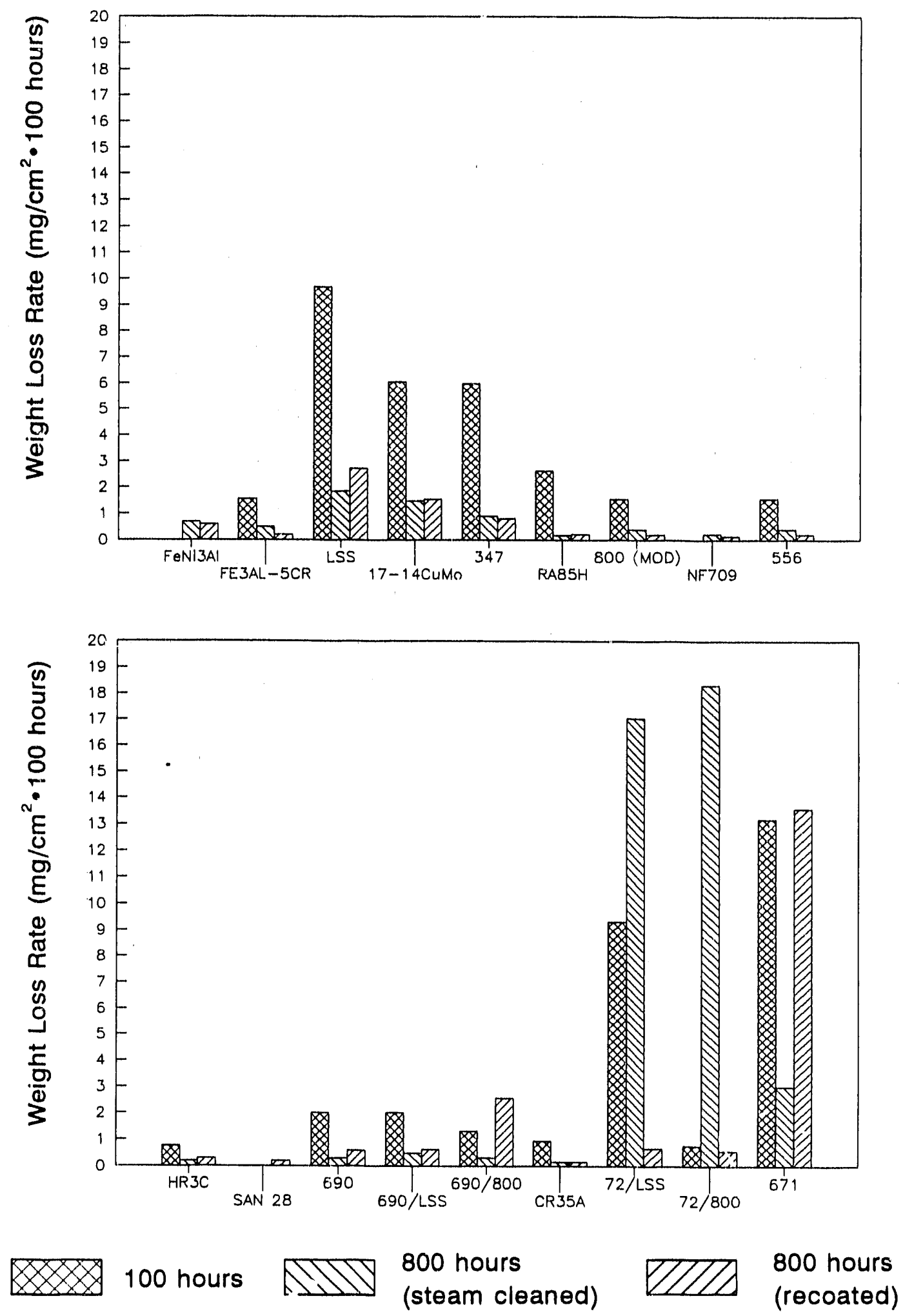

Figure 3.7 Normalized Weight Loss Rates for Al loys Coated With a 10 wt\% Alkali Sulfate Ash and Exposed at $650^{\circ} \mathrm{C}$ to a 0.25 vol\% $\mathrm{SO}_{2}$ Flue Gas 

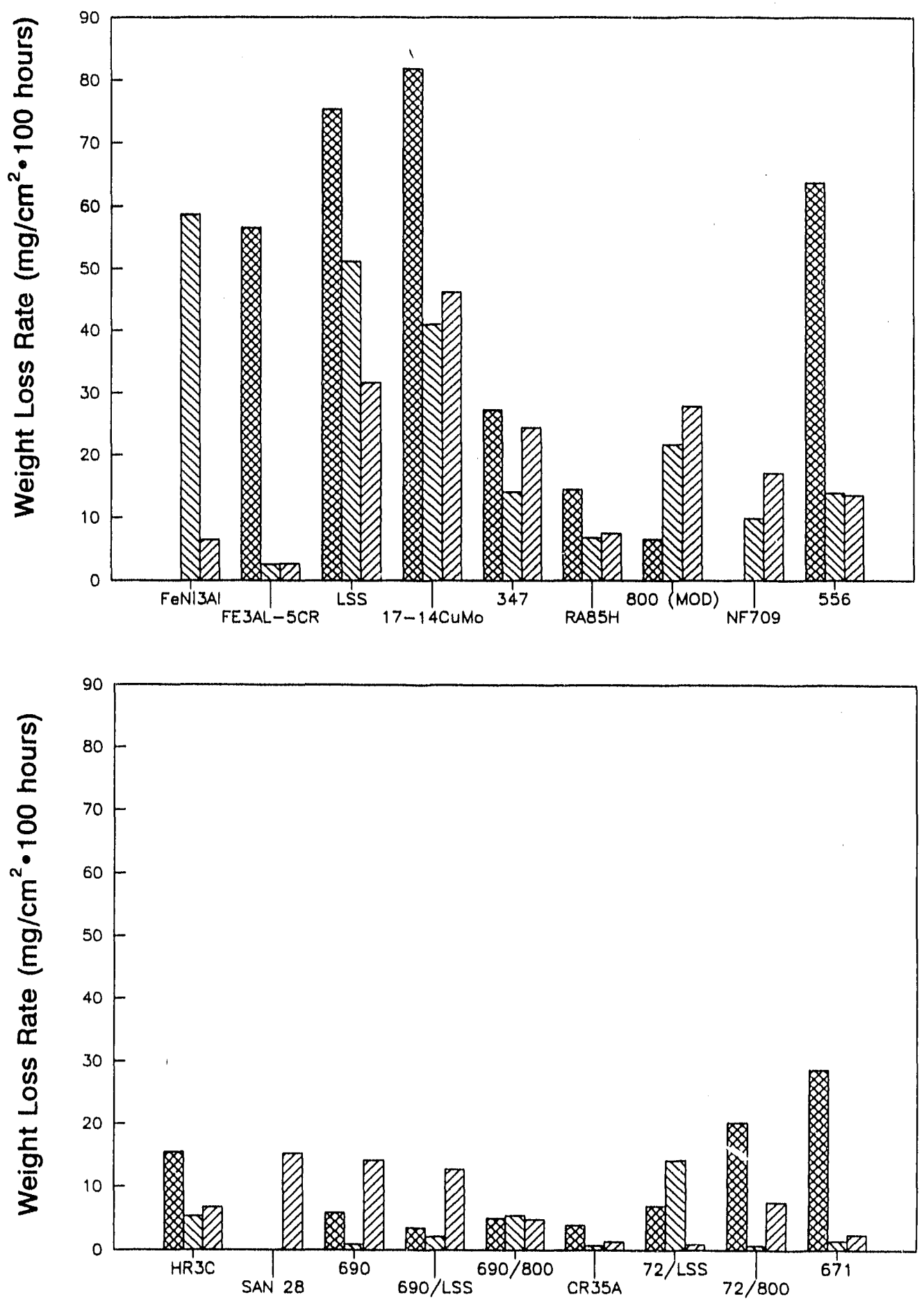

\& 100 hours DIIV $\begin{aligned} & 800 \text { hours } \\ & \text { (steam cleaned) }\end{aligned}$

Figure 3.8 Normalized Weight Loss Rates for Alloys Coated With a 10 wt\% Alkali Sulfate Ash and Exposed at $700^{\circ} \mathrm{C}$ to a 0.25 vol\% $\mathrm{SO}_{2}$ Flue Gas 

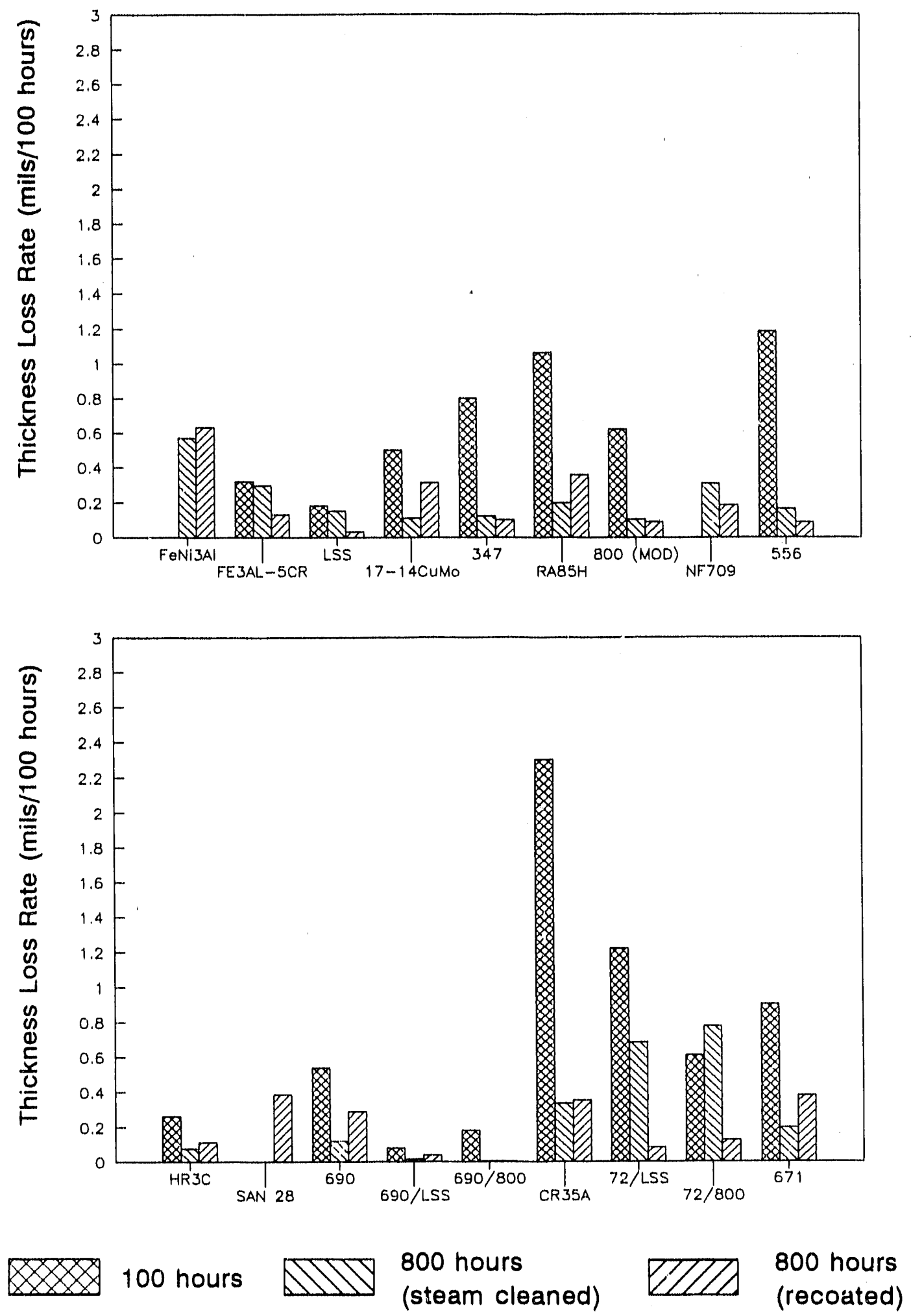

Figure 3.9 Normalized Thickness Loss Rates for Alloys Coated With a 10 wt\% Alkali Sulfate Ash and Exposed at $650^{\circ} \mathrm{C}$ to a 0.25 vol\% $\mathrm{SO}_{2}$ Flue Gas 

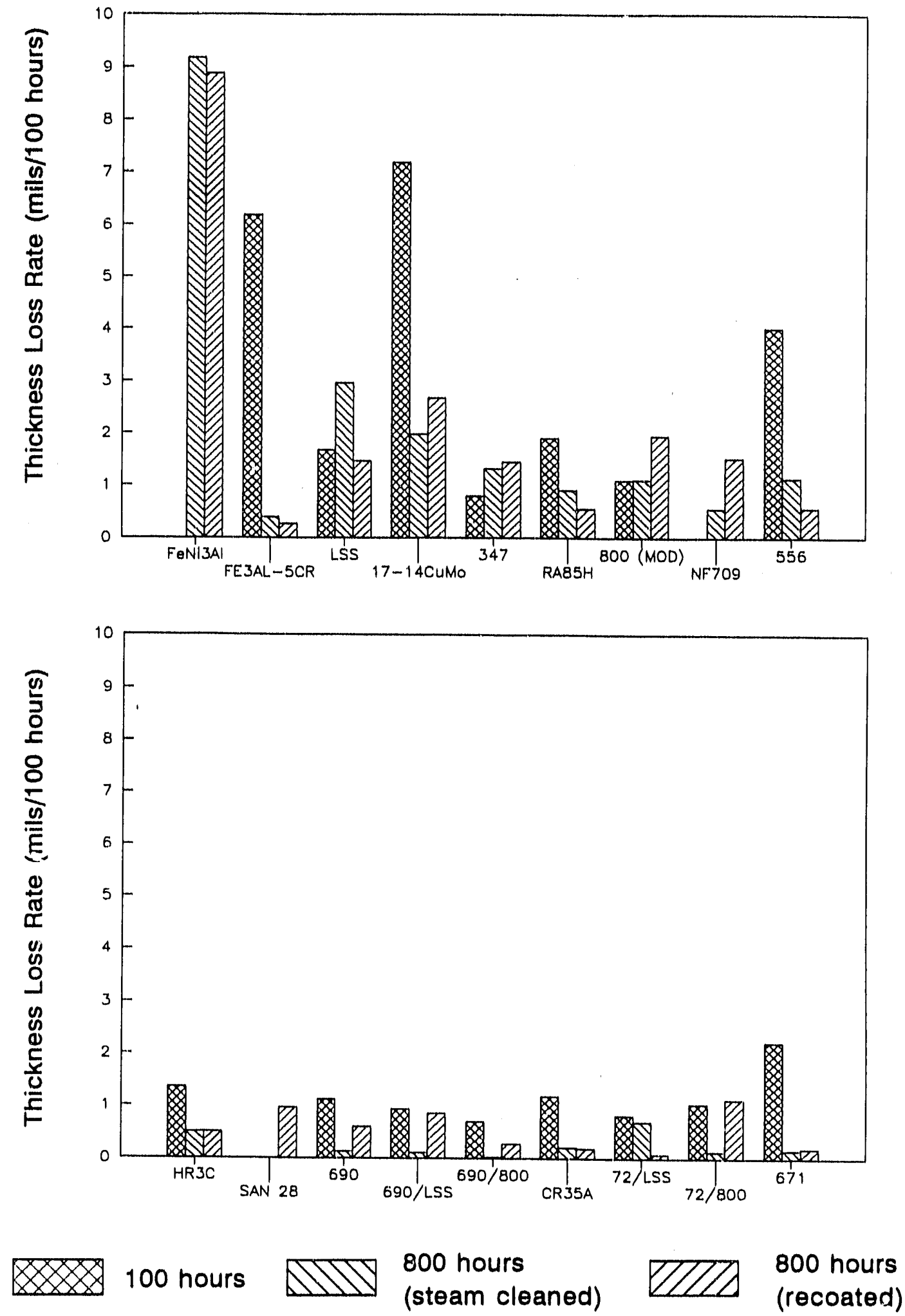

Figure 3.10 Normalized Thickness Loss Rates for Alloys Cuated With a 10 wt\% Alkall Sulfate Ash and Exposed at $700^{\circ} \mathrm{C}$ to a $0.25 \mathrm{vol} \% \mathrm{SO}_{2}$ Flue Gas 

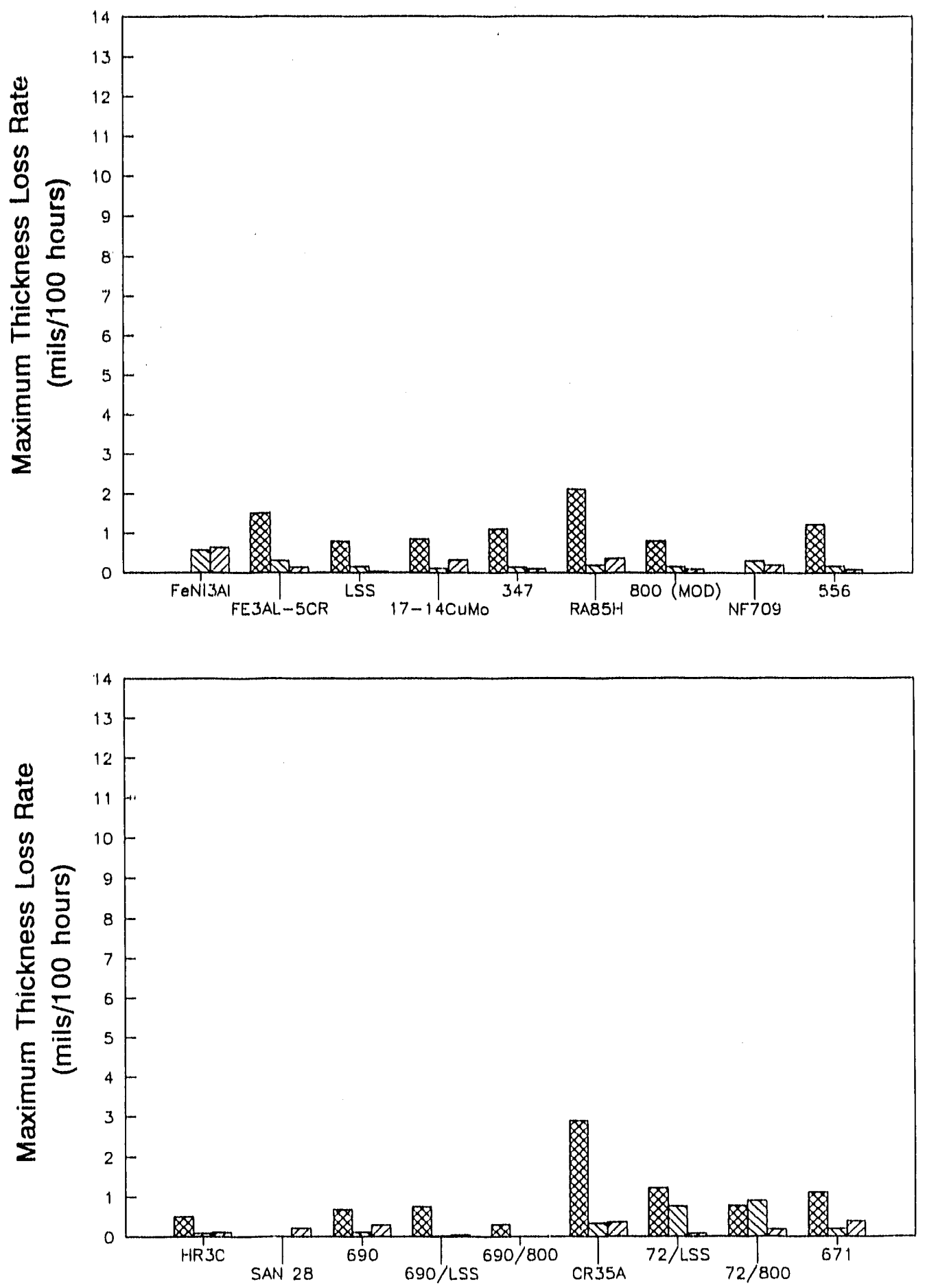

QXX 100 hours DIVT $\begin{aligned} & 800 \text { hours } \\ & \text { (steam cleaned) }\end{aligned}$

Figure 3.11 Normalized Maximum Thickness Loss Rates for Alloys Coated With a 10 wt\% Alkali Sulfate Ash and Exposed at $650^{\circ} \mathrm{C}$ to a 0.25 vol\% $\mathrm{SO}_{2}$ Flue Gas 

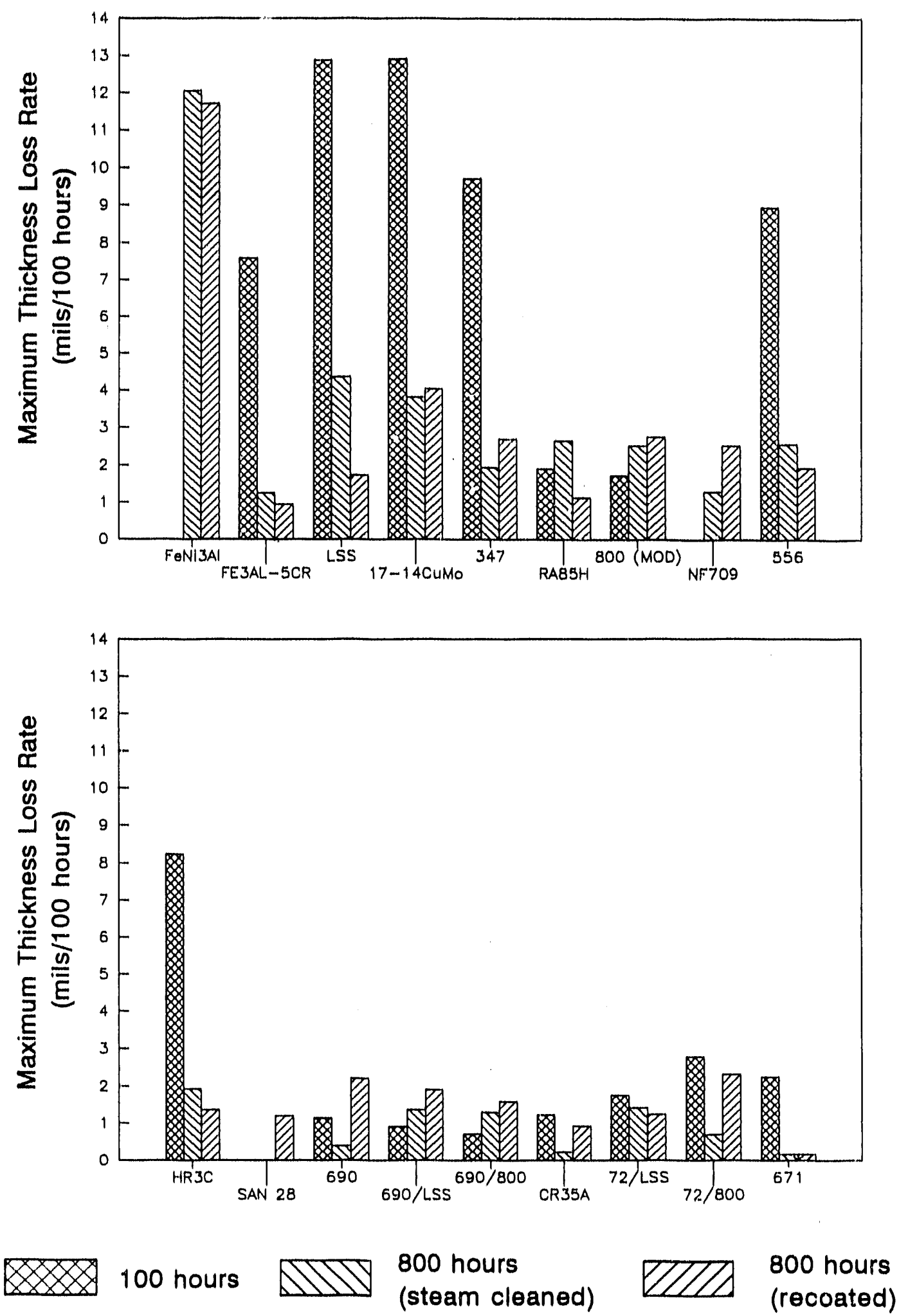

Figure 3.12 Normalized Maximum Thickness Loss Rates for Alloys Coated With a 10 wt\% Alkali Sulfate Ash and Exposed at $700^{\circ} \mathrm{C}$ to a 0.25 vol\% $\mathrm{SO}_{2}$ Flue Gas 


\subsection{RESULTS OF THE 100- AND 800-HOUR LOW-SULFATE 1.0 VO1\% $\mathrm{SO}_{2}$ TESTS}

Tests were conducted with a synthetic coal ash similar in composition to ashes found in $\mathrm{PC}$ - fitred bollers ( $5 \mathrm{Wt} \% \mathrm{Na}_{2} \mathrm{SO}_{4}, 5 \mathrm{wt} \% \mathrm{~K}_{2} \mathrm{SO}_{4}, 30 \mathrm{wt} \% \mathrm{Fe}_{2} \mathrm{O}_{3}$, $30 \mathrm{wt} \% \mathrm{Al}_{2} \mathrm{O}_{3}, 30 \mathrm{wt} \% \mathrm{StO}_{2}$ ). The simulated flue gas (composition: $1.0 \mathrm{vol} \%$ $\mathrm{SO}_{2}, 3.6$ vol\% $\mathrm{O}_{2}, 14.0$ vol\% $\mathrm{CO}_{2}, 10.0$ vol\% $\mathrm{H}_{2} \mathrm{O}, \mathrm{Ba} 1 . \mathrm{N}_{2}$ ) is representative of flue gases found in PC-fired botlers burning high-sulfur coals.

\subsubsection{Netght Loss*}

Weight loss data are shown in Figures 3.13 and 3.14. A11 data have been normalized to $\mathrm{mg}$ lost $/ \mathrm{cm}^{2} / 100$ hours.

\subsubsection{Thickness Losses*}

Data for average thickness losses are shown in Figures 3.15 and 3.16 ; maximum thickness loss data are shown in Figures 3.17 and 3.18. A 11 data have been normalized to mils lost/100 hours.

Specimens are listed in order of increasing chromium content. 

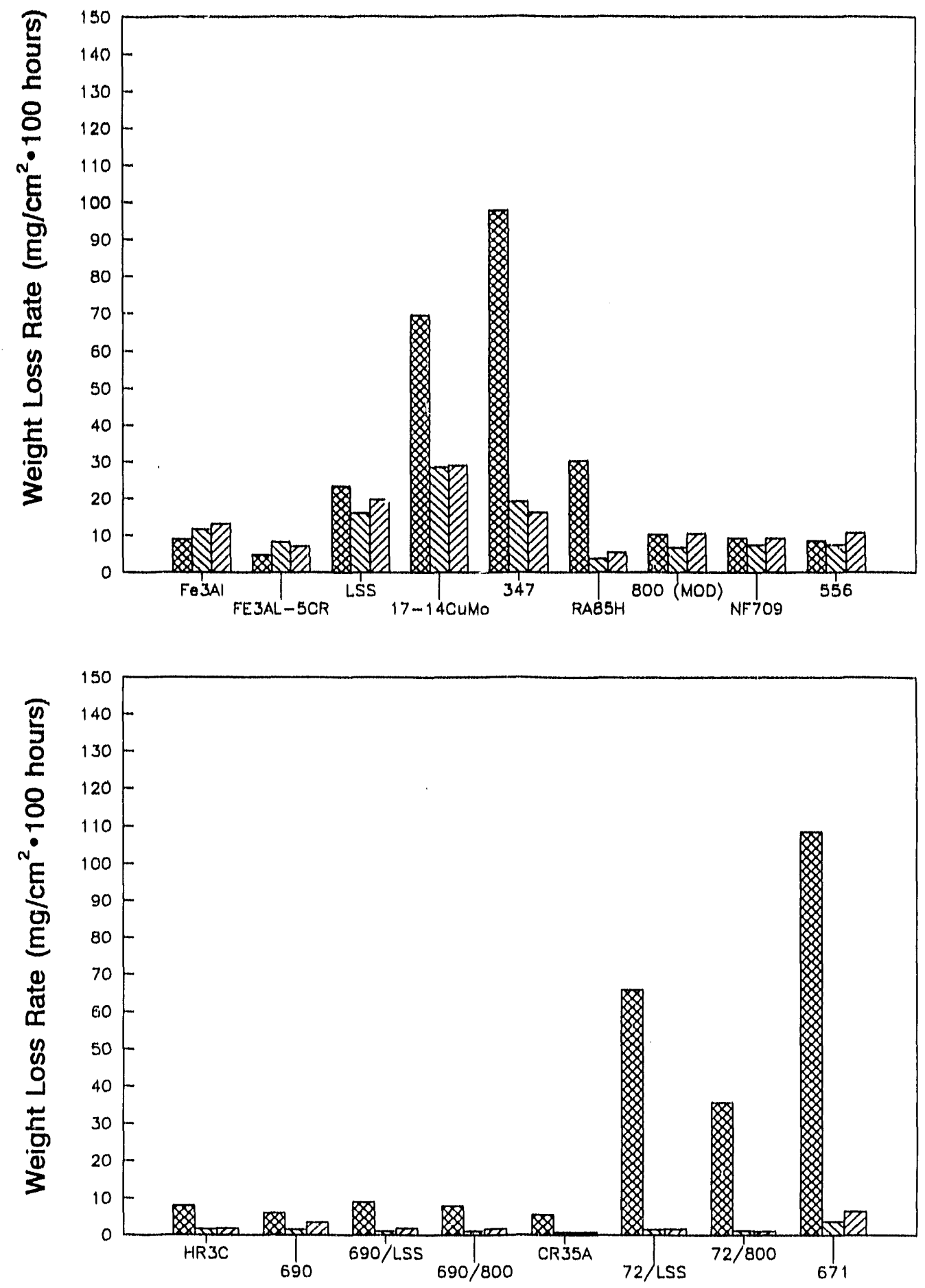

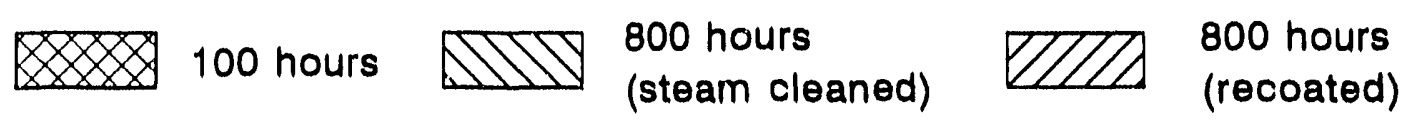

Figure 3.13 Normalized Weight Loss Rates for Alloys Coated With an Ash Containing 10 wt\% Alkali Sulfates and Exposed at $650^{\circ} \mathrm{C}$ to a Flue Gas Containing 1.0 vol\% $\mathrm{SO}_{2}$ 

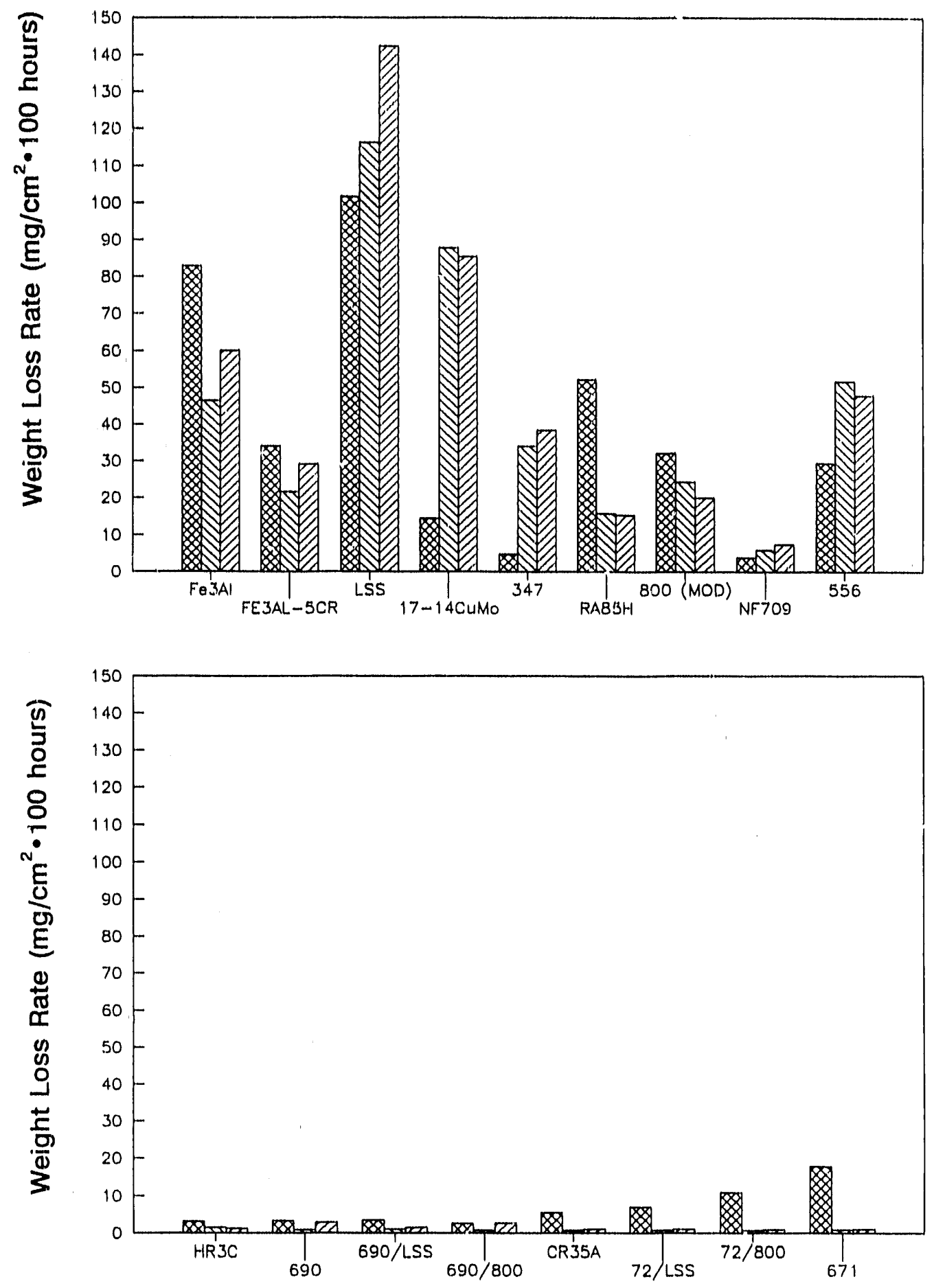

Q8X 100 hours WIVT $\begin{aligned} & 800 \text { hours } \\ & \text { (steam cleaned) }\end{aligned}$

Figure 3.14 Normalized Weight Loss Rates for Alloys Coated With an Ash Containing 10 wt\%. Alkali Sulfates and Exposed at $700^{\circ} \mathrm{C}$ to a Flue Gas Containing $1.0 \mathrm{vol}^{\mathrm{S} \mathrm{SO}_{2}}$ 

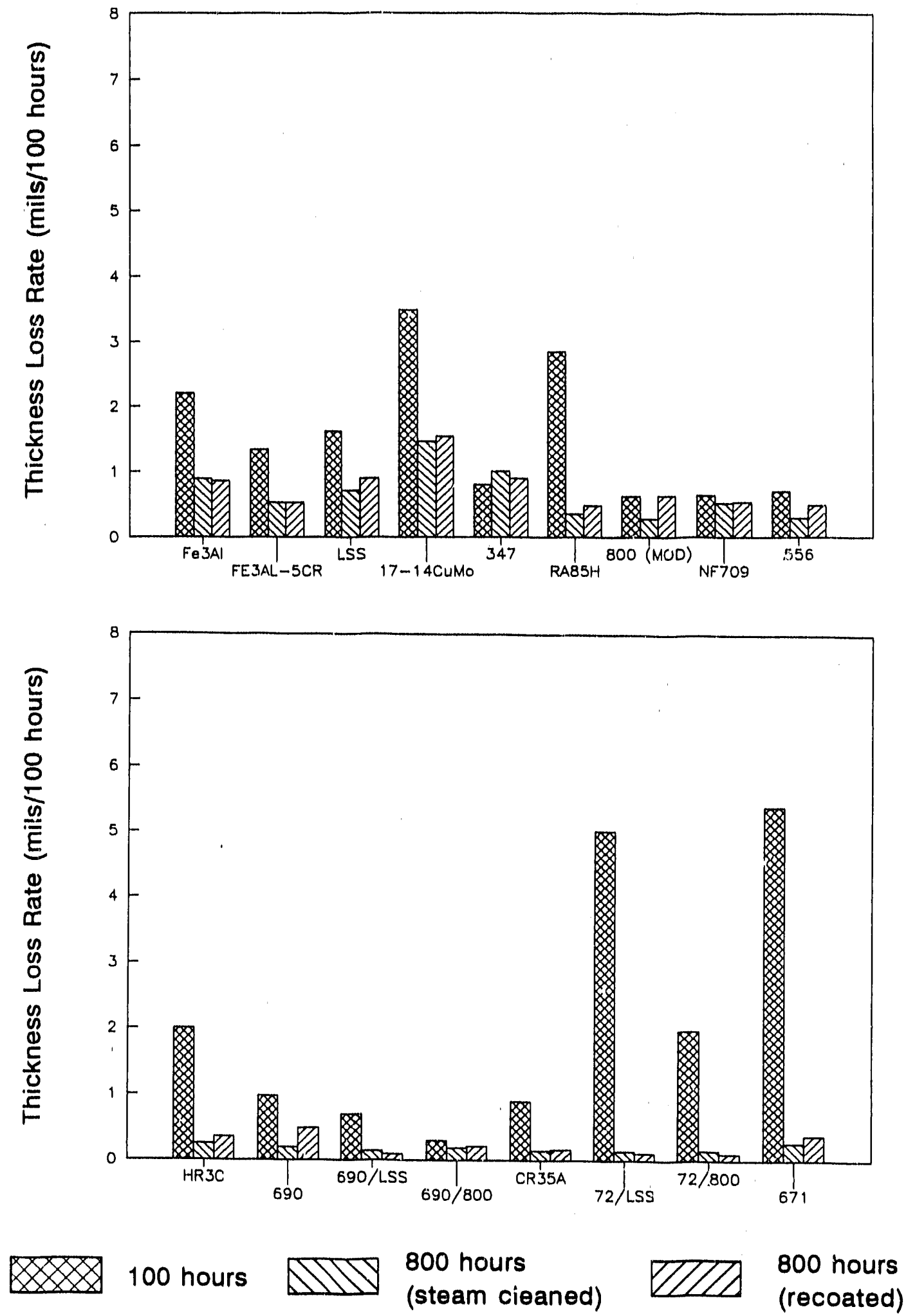

Figure 3.15 Normalized Thickness Loss Rates for Alloys Coated With an Ash Containing $10 \mathrm{wt} \%$ Alkali Sulfates and Exposed at $650^{\circ} \mathrm{C}$ to a Flue Gas Containing 1.0 vol\% $\mathrm{SO}_{2}$ 

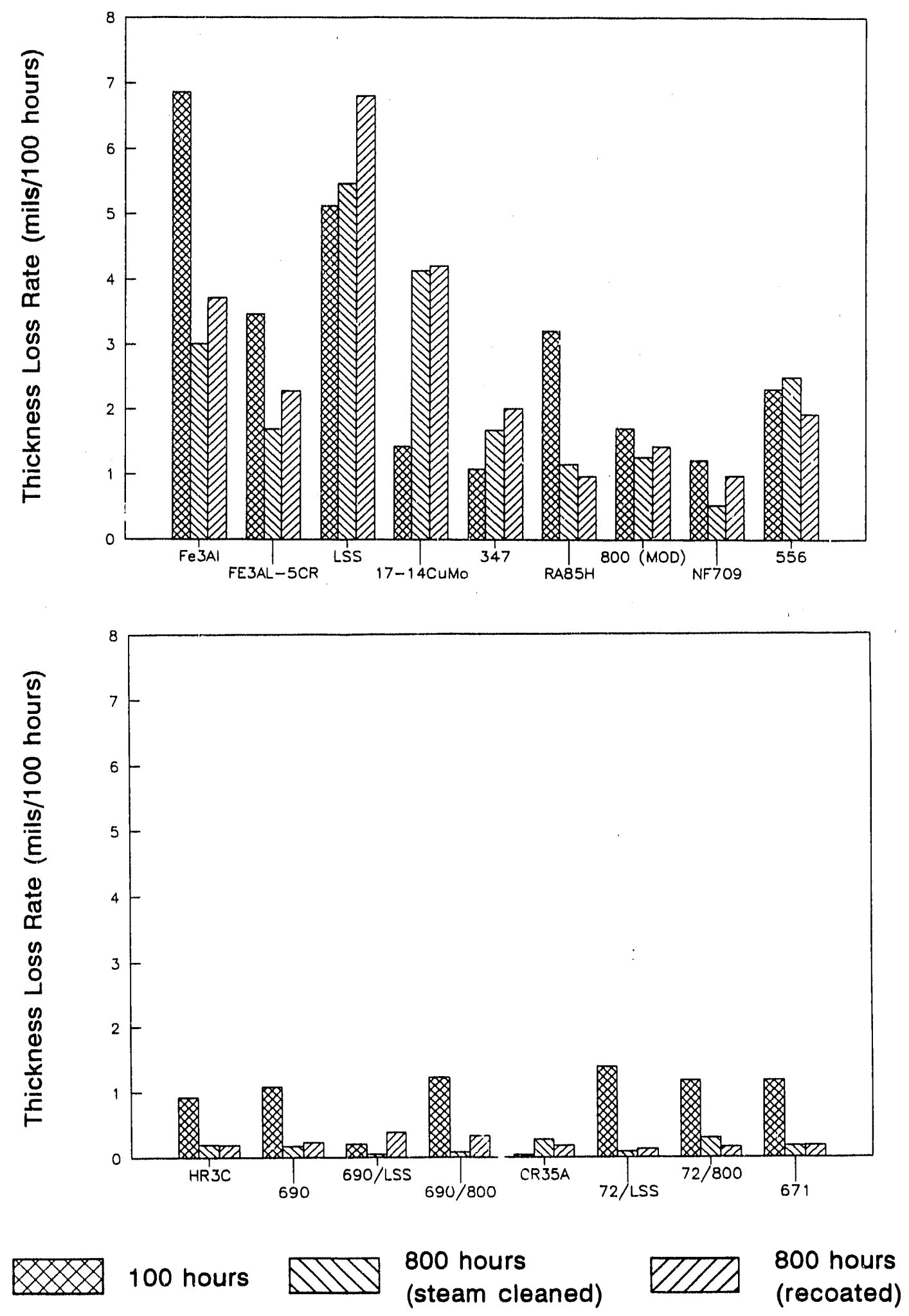

Figure 3.16 Normalized Thickness Loss Rates for Alloys Coated With an Ash Containing 10 wt\% Alkali Sulfates and Exposed at $700^{\circ} \mathrm{C}$ to a Flue Gas Containing 1.0 vol\% $\mathrm{SO}_{2}$ 

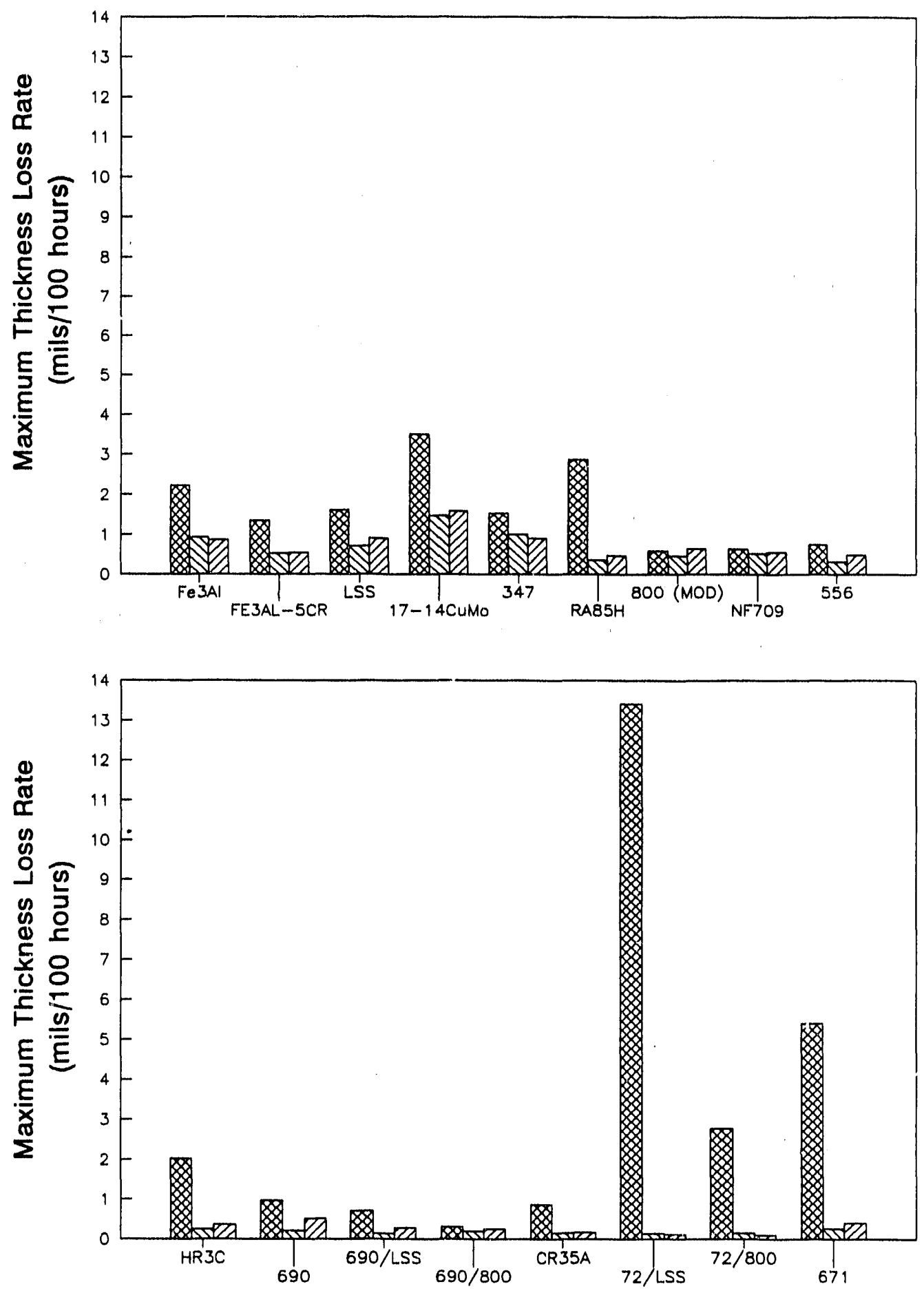

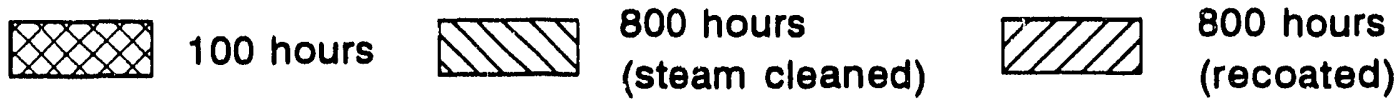

Figure 3.17 Normalized Maximum Thickness Loss Rates for Alloys Coated With an Ash Containing 10 wt\% Alkali Sulfates and Exposed at $650^{\circ} \mathrm{C}$ to a Flue Gas Containing 1.0 vol\% $\mathrm{SO}_{2}$ 

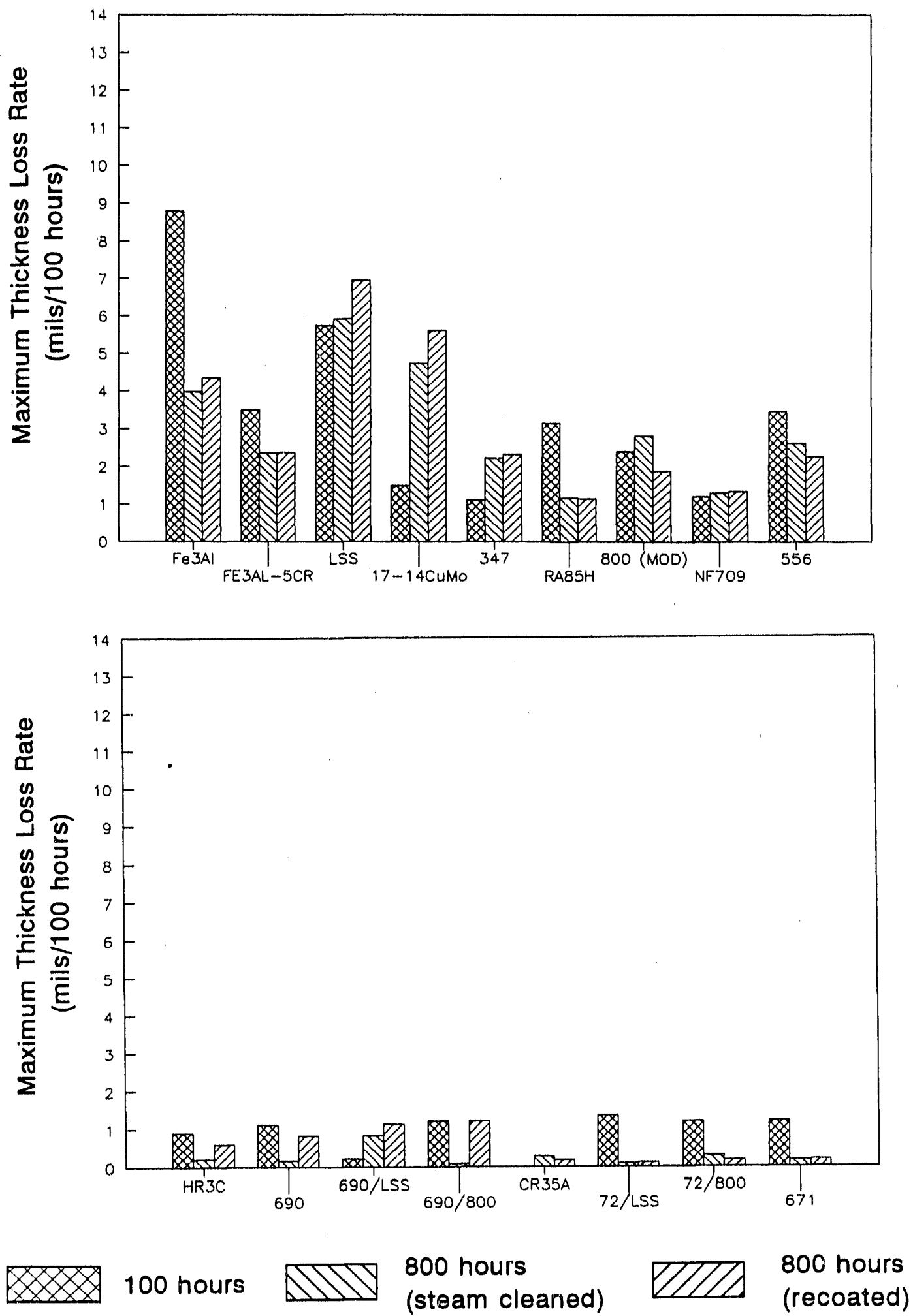

Figure 3.18 Normalized Maximum Thickness Loss Rates for Alloys Coated With an Ash Containing 10 wt\% Alkali Sulfates and Exposed at $700^{\circ} \mathrm{C}$ to a Flue Gas Containing 1.0 vol\% $\mathrm{SO}_{2}$ 


\subsection{EVALUATION OF CHROMIZED SPECIMENS}

The chromized specimens evaluated in this project consisted of a lowalloy core coated with a high-chromium/high-silicon layer. Those specimens were not evaluated by weight and thickness loss measurements, but by visual observations of the integrity of the coating. Table 3.1 summarizes the condition of the chromized specimens after exposure to various environments.

Table 3.1 Visual Evaluations of Chromized Specimens Exposed to Various Simulated Boller Environments

Environment

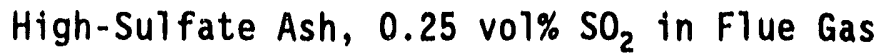

$650^{\circ} \mathrm{C}, 100$ hours

$650^{\circ} \mathrm{C}, 200$ hours steam cleaned

$650^{\circ} \mathrm{C}, 200$ hours recoated

$700^{\circ} \mathrm{C}, 100$ hours

$700^{\circ} \mathrm{C}, 200$ hours steam cleaned

$700^{\circ} \mathrm{C}, 200$ hours recoated

Low-Sulfate Ash, 0.25 v01\% $\mathrm{SO}_{2}$ in Flue Gas

$650^{\circ} \mathrm{C}, 100$ hours

$650^{\circ} \mathrm{C}, 800$ hours steam cleaned

$650^{\circ} \mathrm{C}, 800$ hours recoated

$700^{\circ} \mathrm{C}, 100$ hours

$700^{\circ} \mathrm{C}, 800$ hours steam cleaned

$700^{\circ} \mathrm{C}, 800$ hours recoated

\section{Condition}

Coating Breached

Coating Breached

Coating Breached

Coating Breached

Coating Breached

Coating Breached

Coating Intact

Coating Intact

Coating Intact

Coating Intact

Coating Breached

Coating Breached 


\subsection{EVALUATION OF LEAN STAINLESS STEEL CLAD WITH TYPE 671}

The specimens of lean stainless steel clad with Type 671 that we received contained a thin backing layer of lean stainless steel. Because machining off the backing layer was impractical, the specimens were exposed in the same conditions they were received. Unfortunately, the lean stainless steel backing suffered greater losses as a result of gas-phase attack and descaling than the Type 671 layer did by coal-ash attack. Because of the high losses of the backing, the specimens were evaluated visually. Table 3.21 ists the condition of the Type 671 layer after exposure to various environments.

Table 3.2 Yisual Evaluations of Lean Stainless Steel Clad With Type 671 to Various Simulated Boiler Environments

\section{Environment}

High-Sulfate Ash, 0.25 vol\% $\mathrm{SO}_{2}$ in Flue Gas

$650^{\circ} \mathrm{C}, 100$ hours

$650^{\circ} \mathrm{C}, 200$ hours steam cleaned

$650^{\circ} \mathrm{C}, 200$ hours recoated

$700^{\circ} \mathrm{C}, 100$ hours

$700^{\circ} \mathrm{C}, 200$ hours steam cleaned

$700^{\circ} \mathrm{C}, 200$ hours recoated

Low-Sulfate Ash, 0.25 vol\% $\mathrm{SO}_{2}$ in Flue Gas

$650^{\circ} \mathrm{C}, 100$ hours

$650^{\circ} \mathrm{C}, 800$ hours steam cleaned

$650^{\circ} \mathrm{C}, 800$ hours recoated

$700^{\circ} \mathrm{C}, 100$ hours

$700^{\circ} \mathrm{C}, 800$ hours steam cleaned

$700^{\circ} \mathrm{C}, 800$ hours recoated

Low-Sulfate Ash, 1.0 vol\% $\mathrm{SO}_{2}$ in Flue Gas

$700^{\circ} \mathrm{C}, 100$ hours

$700^{\circ} \mathrm{C}, 800$ hours steam cleaned

$700^{\circ} \mathrm{C}, 800$ hours recoated

\section{Condition}

Light Pitting

Pitting

Pitting

Minor Surface Attack Minor Surface Attack No Corrosion

No Corrosion

No Corrosion

Minor Surface Attack

No Corrosion

Minor Surface Attack

Minor Surface Attack

Minor Surface Attack

Minor Surface Attack

Minor Surface Attack 


\section{Section 4 \\ EFFECTS OF ENVIRONMENTAL VARIABLES AND COMPOSITION ON RESISTANCE OF MATERIALS TO ALKALI-IRON TRISULFATE ATTACK}

\subsection{EFFECTS OF CHROMIUM ON ALLOY RESISTANCE}

Past studies by Rehn [1-3] and Kihara and Wolowodiuk [4] have shown the strong influence of chromium content in an alloy on the corrosion resistance of that alloy to trisulfate attack. Figure 4.1 presents the relative corrosion rates of the alloys tested in relationship to their chromium content. The trend shown confirms the results previously mentioned: the corrosion resistance of an alloy increases as chromium content rises. Figures 4.2 through 4.4 show subsets of the plot in Figure 4.1 . Figures 4.2 , 4.3 , and 4.4 respectively show the corrosion rates for alloys exposed to 0.25 vol\% $\mathrm{SO}_{2}$ while coated with coal ash containing 10 wt\% alkali sulfates (the mildest environment), alloys exposed to 1.0 vol\% $\mathrm{SO}_{2}$ while coated with coal ash containing 10 wt\% alkali sulfates (a moderate environment), and alloys exposed to 0.25 vol\% $\mathrm{SO}_{2}$ while coated with coal ash containing 75 wt\% alkali sulfates (the harshest environment). As Figures 4.2 and 4.3 illustrate, the alloys ccitaining chromium above 25 wt\% (approximately) exhibited rather low corrosion rates in environments simulating conditions inside a boller firing moderate-to high-sulfur coals. Even when subjected to a synthetic ash much higher in trisulfate content than would ever be found in a boiler, alloys with a chromium content greater than 25 wt\% performed much better than the alloys with chromium contents less than 25 wt\%. Among the alloying elements evaluated in this study, none was as effective as chromium in providing hot corrosion resistance.

\subsection{EFFECTS OF OTHER ALLOYING ELEMENTS ON ALLOY RESISTANCE}

Elements other than chromium have both beneficially and detrimentally affected the corrosion resistance of an alloy to AIT. In a laboratory study by Rehn [1], AL-6X, containing 6-percent molybdenum, had less resistance to AIT attack than similar alloys without molybdenum (IN-840 or Type 310 ). Kihara and Wolowodiuk noted greater wastage rates on Incone 617 than on alloys with similar chromium contents [4]. They attributed this greater wastage to the high molybdenum content of Incone? 617 ( 8.5 percent). Figure 4.5 illus trates the comparative corrosion rates of six stainless steels in four different environments. The alloys shown range in chromium content from 14 to 30 wt\%. Alloys containing 1 to $4 \mathrm{wt} \%$ molybdenum are marked with an asterisk. These alloys display less resistance to corrosion than alloys with comparable chromium contents (Type 347, RA85H, HR3C), validating the previous work.

A clear consensus was not reached in previous studies on the effects that aluminum and silicon have on the corrosion resistance of an alloy. Both silicon and aluminum were found by Rehn to be beneficial in reducing corrosion of alloys exposed to 100 percent AIT [1]. Rehn developed a high-sificon/ high-aluminum alloy, Alloy $4 \mathrm{C},(20 \% \mathrm{Cr}, 20 \% \mathrm{Ni}, 2.5 \% \mathrm{Si}, 2.0 \% \mathrm{Al})$, which 


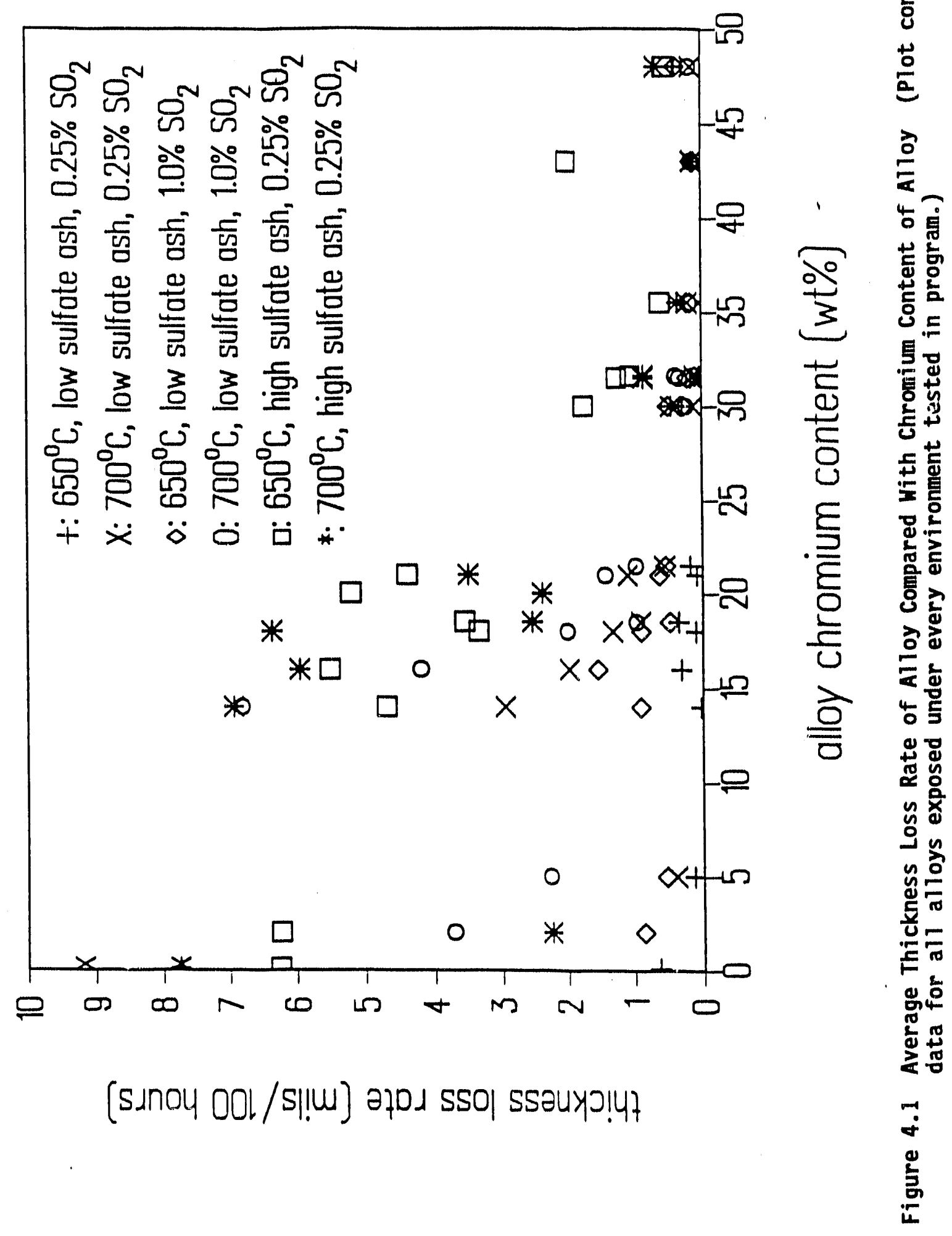




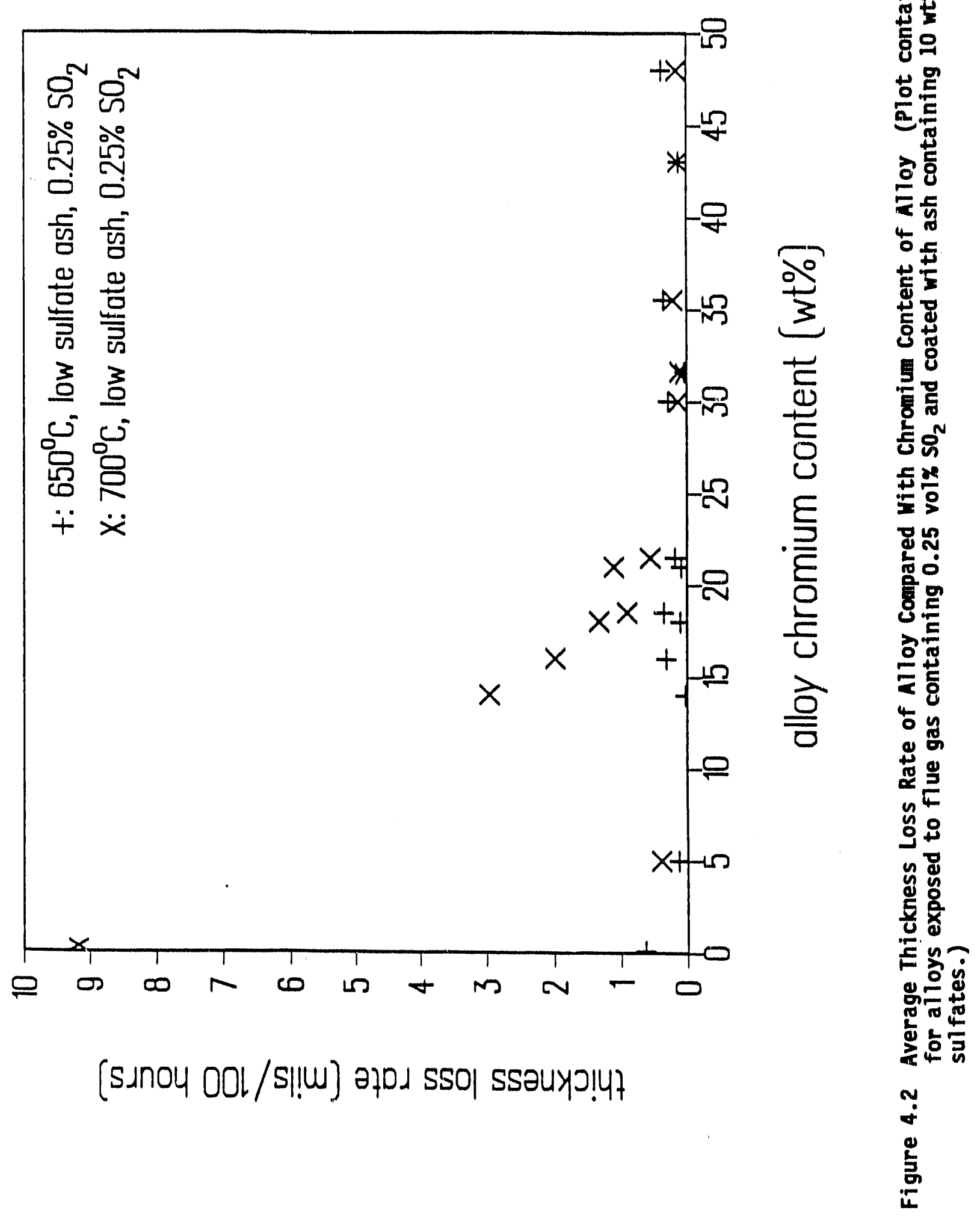




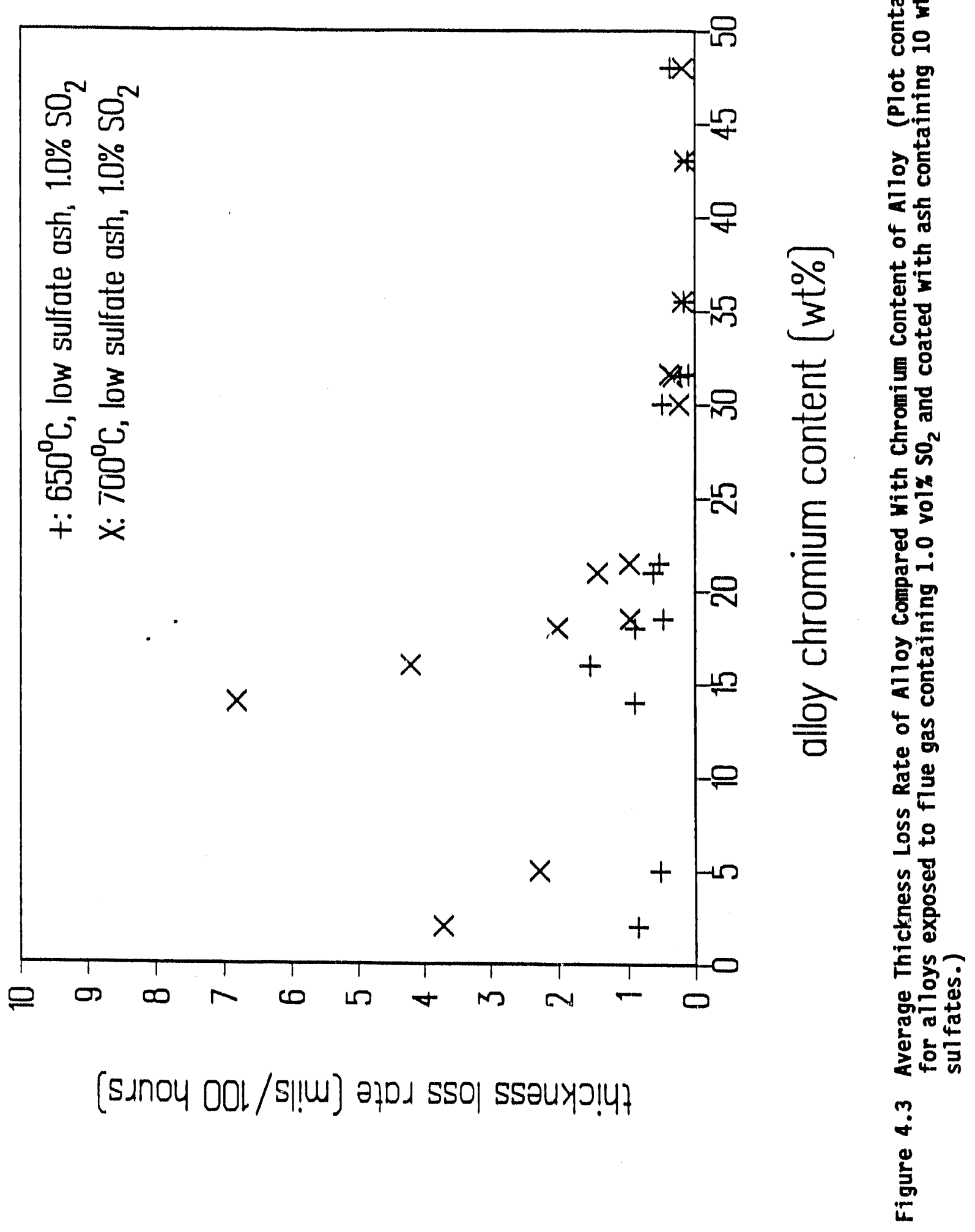




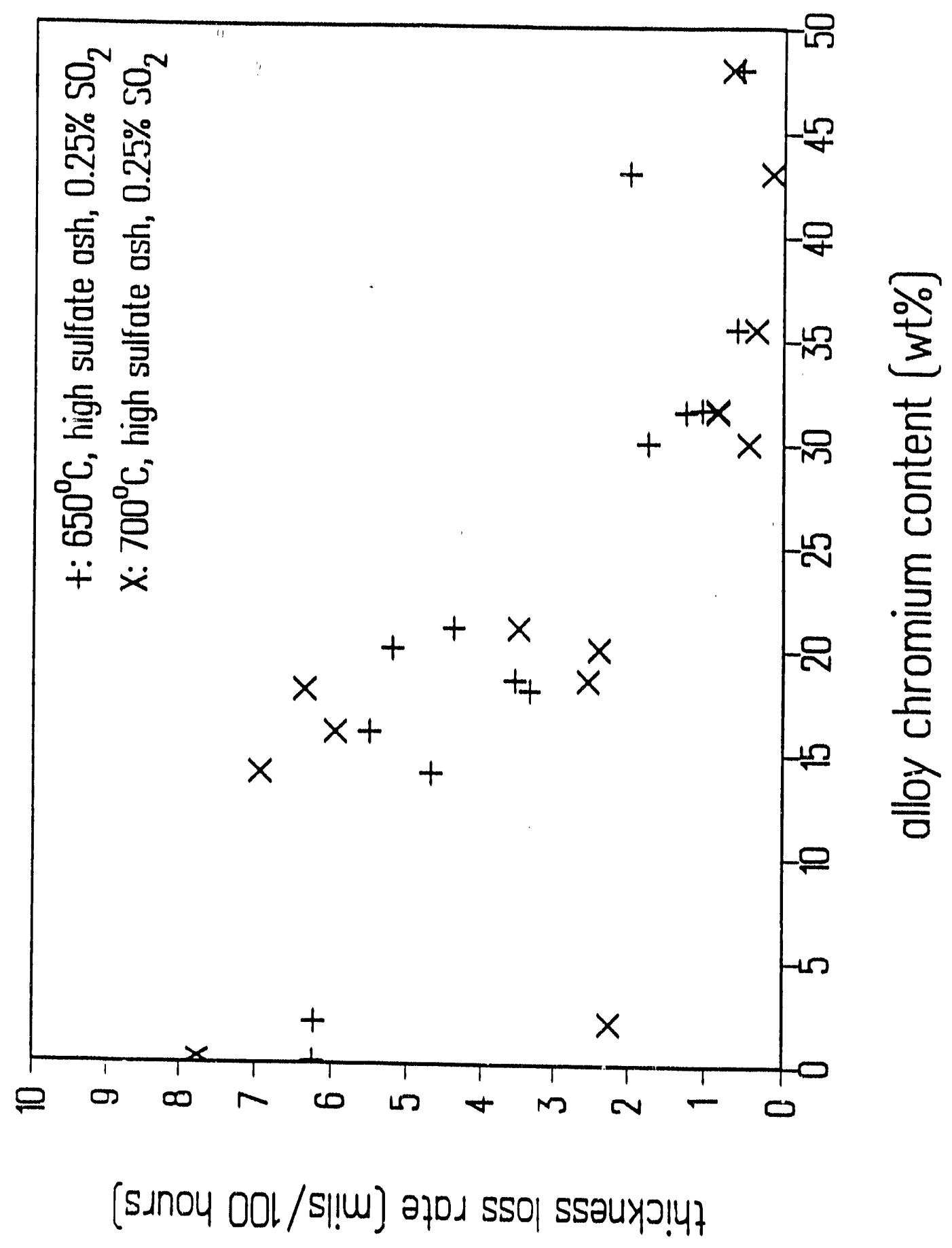

营营 


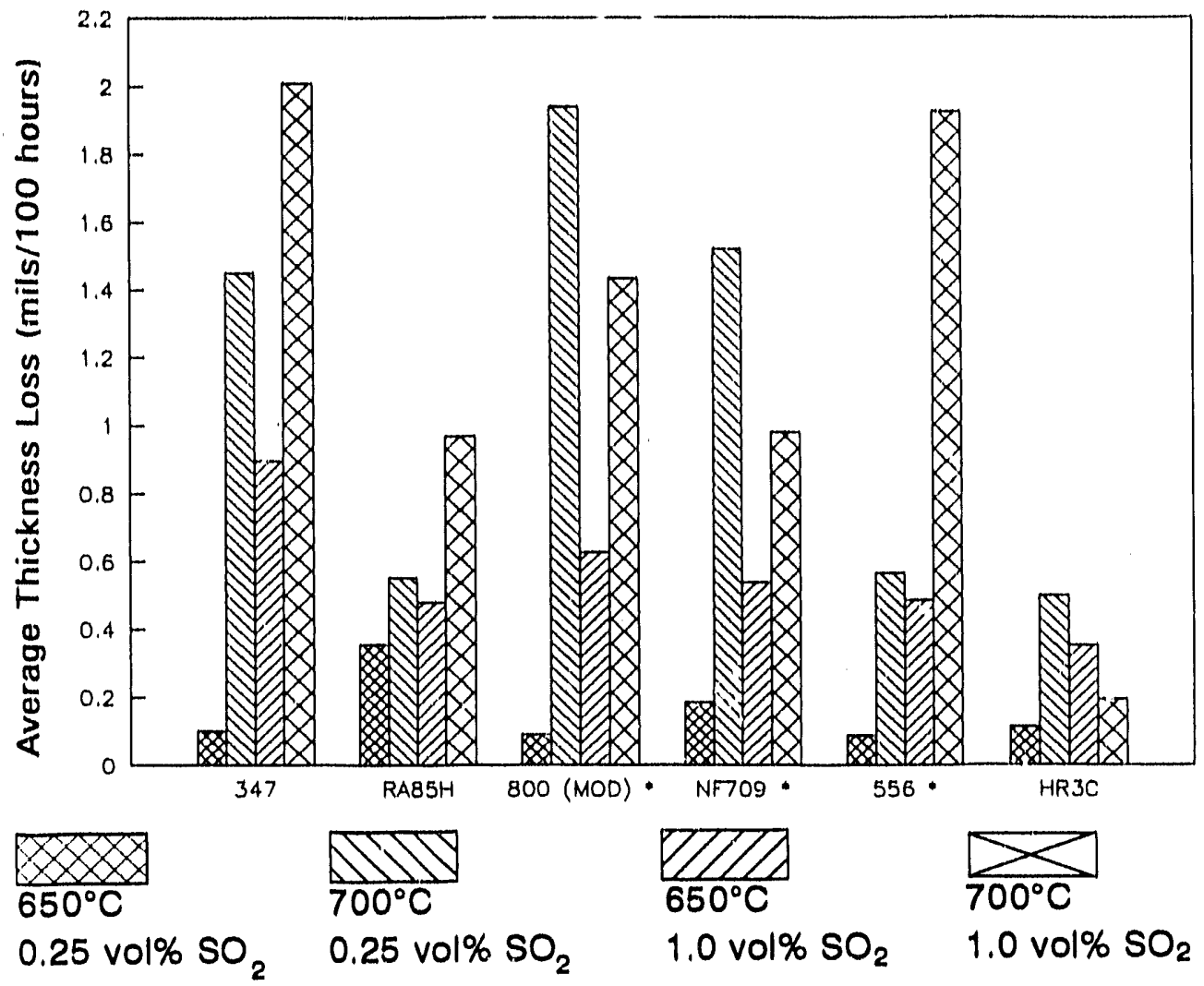

Figure 4.5 Average Thickness Loss Rate of Alloys Containing 14- to 30-Percent Chromium (Alloys marked with an asterisk contain between 1 arid 4 percent molybdenum.)

showed markedly better corrosion resistance in 100 percent AIT than alloys of similar chromium and nickel contents. In a later work, Alloy $4 C$ and highsilicon high-aluminum commercial alloys were exposed, using ashes containing between $2.5 \%$ and $10 \%$ alkali sulfates. In these tests silicon and aluminum had no noticeable beneficial effects [4].

As shown in Figure 4.5, RA85H, a high-silicon high-aluminum alloy with a chromium content between that found in Type 347 and the modified $800 \mathrm{H}$ displays twice the corrosion resistance of the former and three times the corrosion resistance of the latter, a finding that would seem to validate Rehn's work. 


\subsection{CLAD ALLOYS}

Figure 4.6 lllustrates the comparative corrosion resistance of base metals and cladding of the same nominal compositton. The cladding performed as well as the base metals within the range of scatter for these tests. Two exceptions are the $690 \mathrm{clad}$ Type 316 exposed to 0.25 vol\% $\mathrm{SO}_{2}$ at $700^{\circ} \mathrm{C}$ and the $72-\mathrm{Cl}$ ad 800 exposed to 0.25 vol\% $\mathrm{SO}_{2}$ at $700^{\circ} \mathrm{C}$. The reasons for the lowered corrosion resistance of these specimens are discussed in Section 4.8.

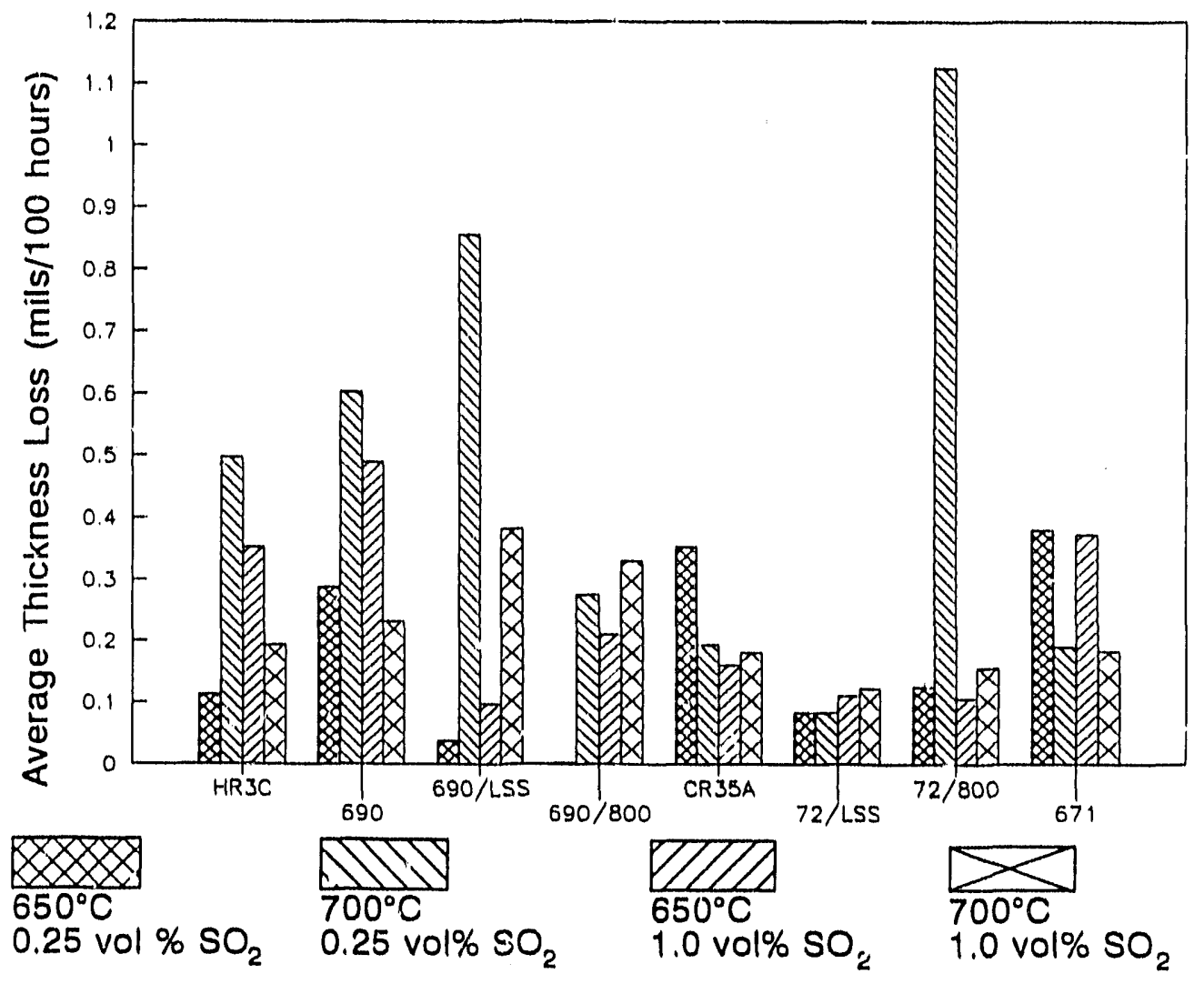

Figure 4.6 Average Thickness Loss Rates of Various Monolithic Alloys and Clacidings Coated With Ash Containing 10 wt\% Alkali Sulfates and Exposed for 800 Hours 


\subsection{ALUMINIDE ALLOYS}

Corrosion losses of the aluminide alloys and two stainless steels are shown in Figure 4.7. Aluminide alloy development projects were undertaken concurrently with this test program, consequently improved alloys unavallable at the beginning of the program were incorporated in later stages.

Iron nickel aluminide specimens performed poorly in all environments. At $700^{\circ} \mathrm{C}$, when exposed to a flue gas containing 1.0 vol\% $\mathrm{SO}_{2}$ the iron-nickel aluminide suffered catastrophic wastage. Most of the specimen was completely converted to scale. The morphology of attack on the iron-nickel aluminides appears to be primarlly oxidation and sulfidation rather than ilquid salt attack. In contrast to the iron-nickel aluminide, the iron aluminides did not suffer catastrophic wastage. Both aluminides were subjected to approximately the same degree of attack as the low-chromium stainless steels, with the fron aluminide containing 5 wt\% chromium generally suffering less wastage than the iron aluminide containing 2 wt\% chromium.

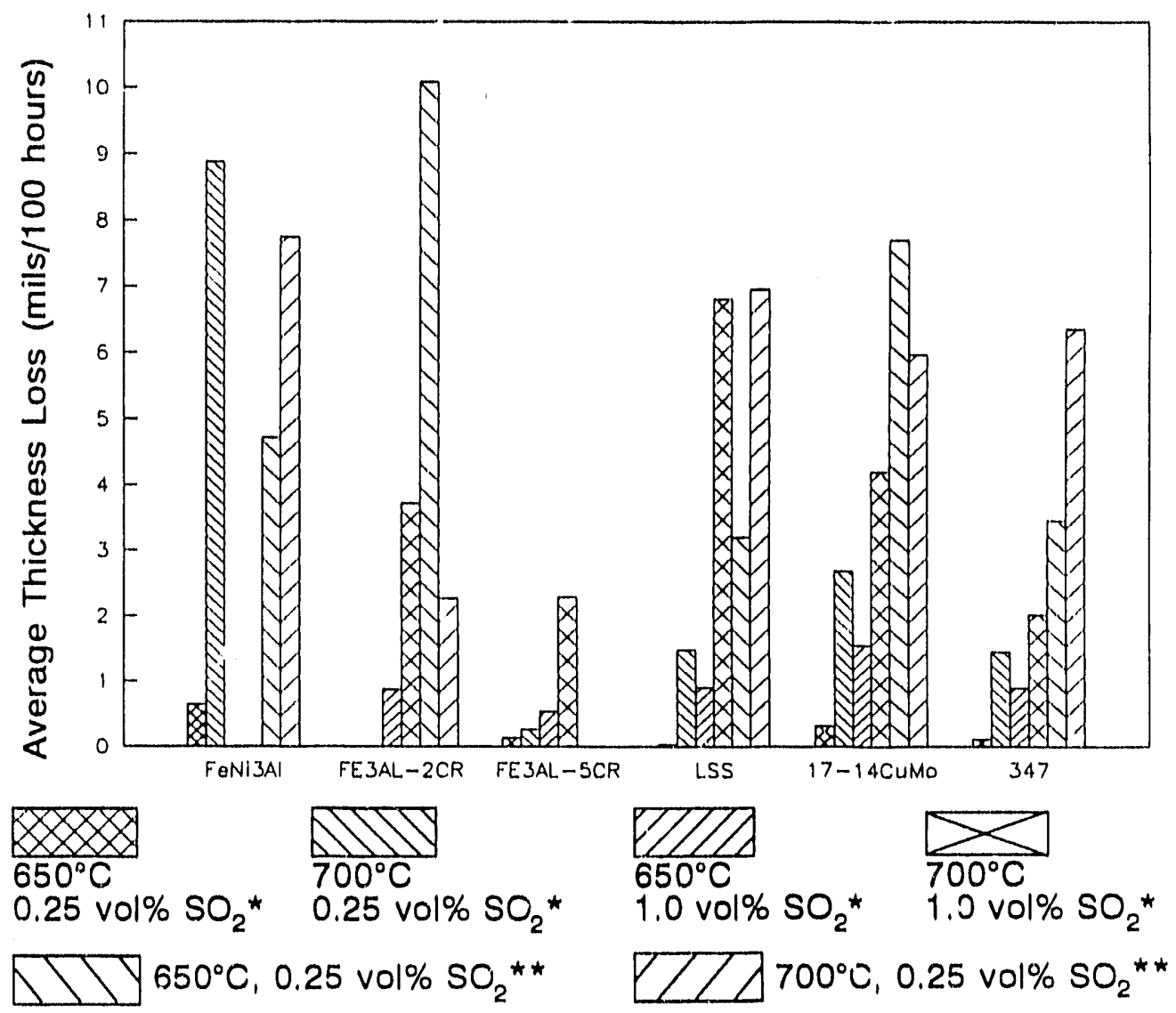

Figure 4.7 Average Thickness Loss Rates of Three Intermetallic Aluminides and Two Stainless Steels Exposed to a Variety of Environments (* - Low Sulfate Ash, ** . High Sulfate Ash) 


\subsection{INFLUENCE OF ENVIRONMENT UN HASTAGE RATES}

The effects of temperature, $\mathrm{SO}_{2}$ concentration in the flue gas, sulfate content of the ash, exposure time, and steam cleaning between exposures on the corrosion rates of vartous alloys are discussed in the following paragraphs. To prevent confusion and "information overload, "only the corrosion rates of a representative selection of alloys in selected environments are given.

Figures 4.8 through 4.10 present the effects of temperature on the average thickness loss rates of alloys. Figures 4.8 and 4.9 show the corroston rates of alloys coated with a coal ash containing 10 wt\% alkali sulfate. and exposed to a flue gases containing 0.25 and 1.0 vol\% $\mathrm{SO}_{2}$ respectively. Figure 4.10 fllustrates the corrosion rates of alloys coated with a coal ash containing 75 wt\% alkali sulfates while exposed to a flue gas containing $0.25 \mathrm{vol}^{2} \mathrm{SO}_{2}$.

The alloys coated with the low-sulfate ash and exposed to 0.25 vol\% $\mathrm{SO}_{2}$ (Figure 4.8) show minimal wastage at $650^{\circ} \mathrm{C}$, indicating that liquid AITs may have had difficulty forming because of the lower $\mathrm{SO}_{2}$ level. Specimens exposed at $700^{\circ} \mathrm{C}$ can be divided into two groups-alloys exhibiting wastage rates similar to those exposed at $650^{\circ} \mathrm{C}$ and alloys suffering much greater wastage at $700^{\circ} \mathrm{C}$ than at $650^{\circ} \mathrm{C}$. A possible explanation for this behavior is that the alloys with high wastage rates promote the formation of a liquid phase. Several of the alloy's exhibiting high wastage rates contained a

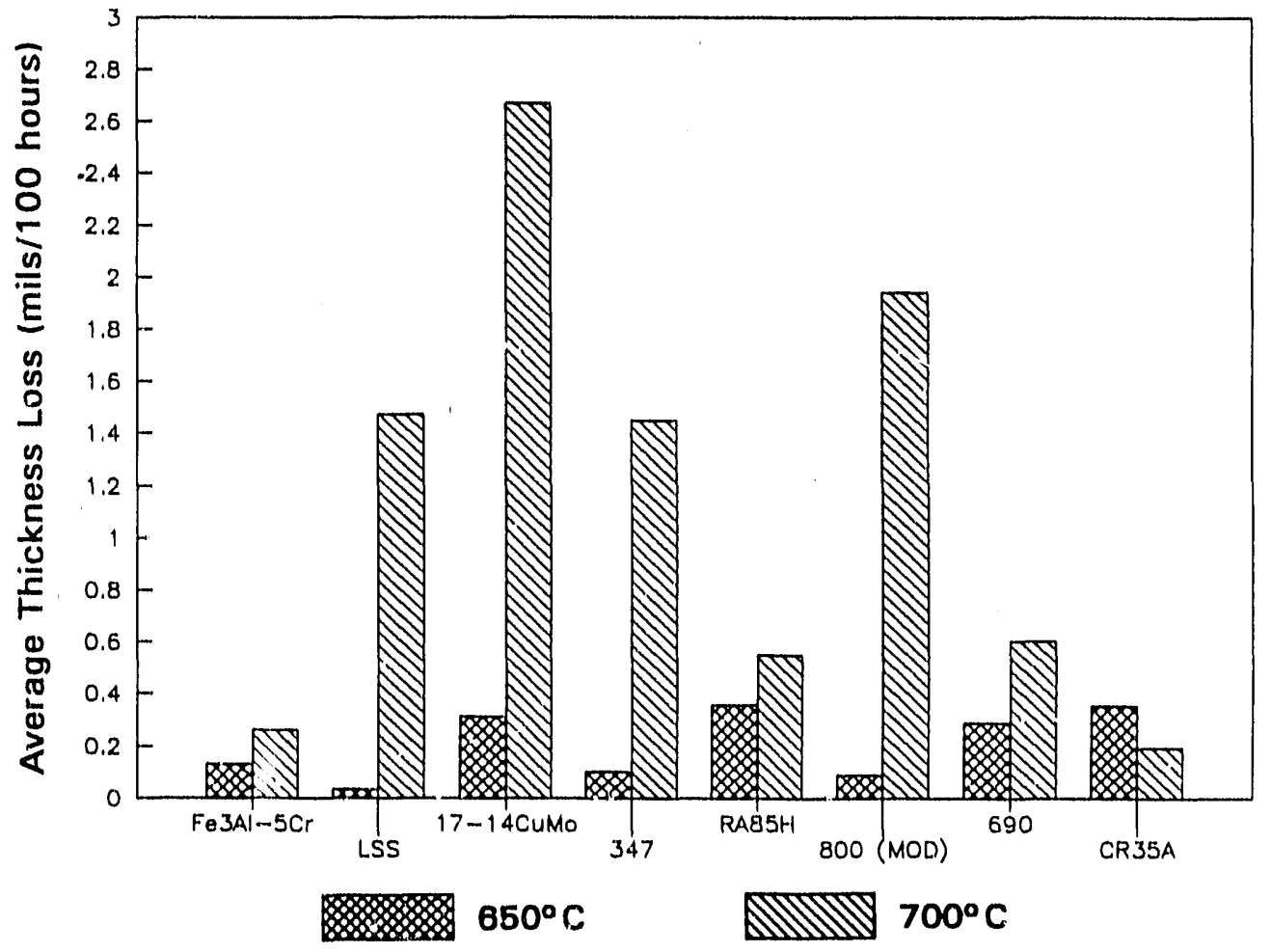

Figure 4.8 Average Thickness Loss Rates of Representative Alloys Coated With Ash Containing 10 wt\% Alkali Sulfates and Exposed at 650 and $700^{\circ} \mathrm{C}$ for 800 Hours to Flue Gas Containing 0.25 vol\% $\mathrm{SO}_{2}$ 
substantial amount of molybdenum, which had been found by Rehn to promote AIT attack [1].

Lower-chromium alloys exposed to a flue gas containing 1.0 vol\% $\mathrm{SO}_{2}$ while coated with the lower-sulfate coal ash (Figure 4.9) suffered greater wastage rates at $700^{\circ} \mathrm{C}$ than at $650^{\circ} \mathrm{C}$, while the hightr-chromium alloys $(690$ and (R35A) exhibited approximately the same corrosion rates at $650^{\circ} \mathrm{C}$ as at $700^{\circ} \mathrm{C}$. Note also that the corrosion rates of the alloys drop as the chromium content of the alloy increases, illustrating the beneficial effect of chromium.

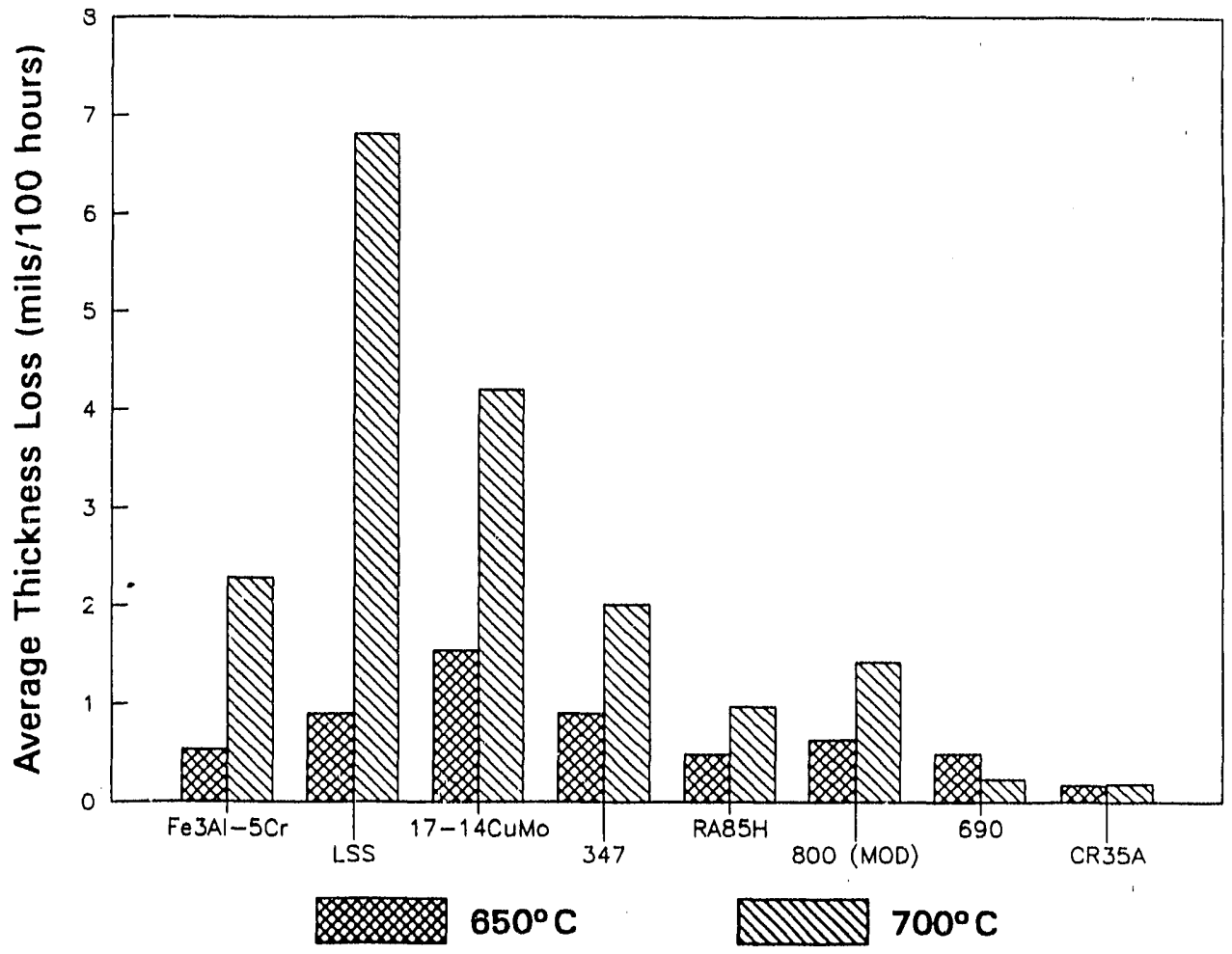

Figure 4.9 Average Thickness Loss Rates of Representative Alloys Coated With Ash Containing 10 wt\% Alkali Sulfates and Exposed at 650 and $700^{\circ} \mathrm{C}$ for 800 Hours to Flue Gas Containing 1.0 vol\% $\mathrm{SO}_{2}$

The alloys coated with a 75 wt\% alkali sulfate coal ash while exposed to 0.25 vol\% $\mathrm{SO}_{2}$ flue gas (Figure 4.10 ) did not display a consistent temperature dependence. The two higher-chromium alloys (690 and CR35A) suffered greater corrosion losses at $650^{\circ} \mathrm{C}$ than at $700^{\circ} \mathrm{C}$, a dependence found in previous studies by Kihara [4] and Rehn [1]. 


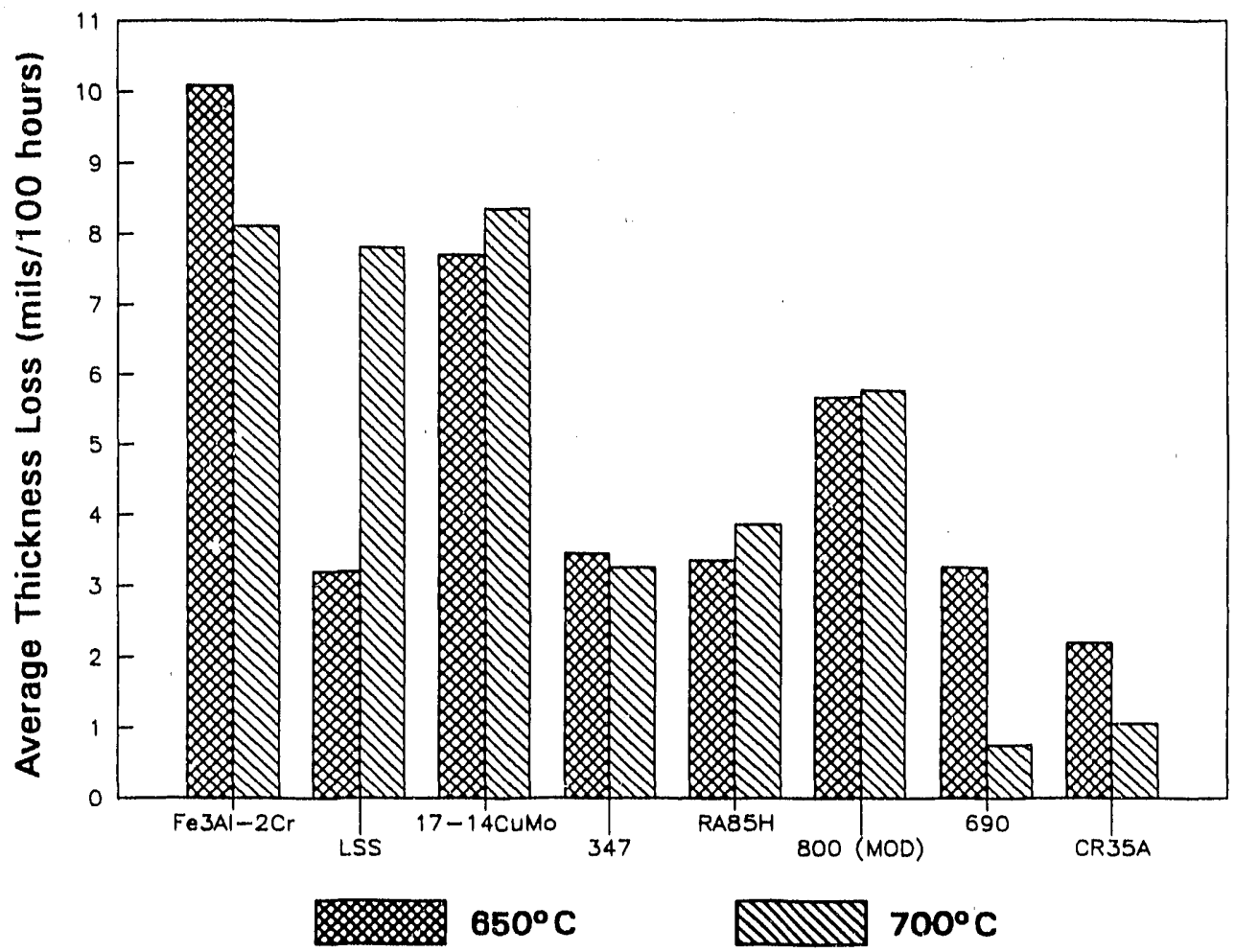

Figure 4.10 Average Thickness Loss Rates of Representative Alloys Coated With Ash Containing 75 wt\% Alkali Sulfates and Exposed at 650 and $700^{\circ} \mathrm{C}$ for 200 Hours to Flue Gas Containing 0.25 vol\% $\mathrm{SO}_{2}$

The effects of increased $\mathrm{SO}_{2}$ in the flue gas and a higher sulfate concentration in the coal ash are illustrated in Figures 4.11 through 4.14. Figures 4.11 and 4.12 display the effects of $\mathrm{SO}_{2}$ concentration on the corrosion rates of alloys coated with 10 wt\% sulfate coal ash and exposed for eight 100 -hour cycles at 650 and $700^{\circ} \mathrm{C}$ respectively, with ash replenishment between cycles. Figures 4.13 and 4.14 show the effects of an increased sulfate concentration in the coal ash on the corrosion rates of alloys exposed to flue gas containing $0.25 \mathrm{vol \%} \mathrm{SO}_{2}$ and for 100 hours at 650 and $700^{\circ} \mathrm{C}$ respectively. An increase in both the $\mathrm{SO}_{2}$ concentration in the flue gas and the sulfate concentration in the coal ash would be expected to produce a more aggressive environment. As shown in the figures, an increase in either the $\mathrm{SO}_{2}$ level or the sulfate concentration will raise the corrosion rate. 


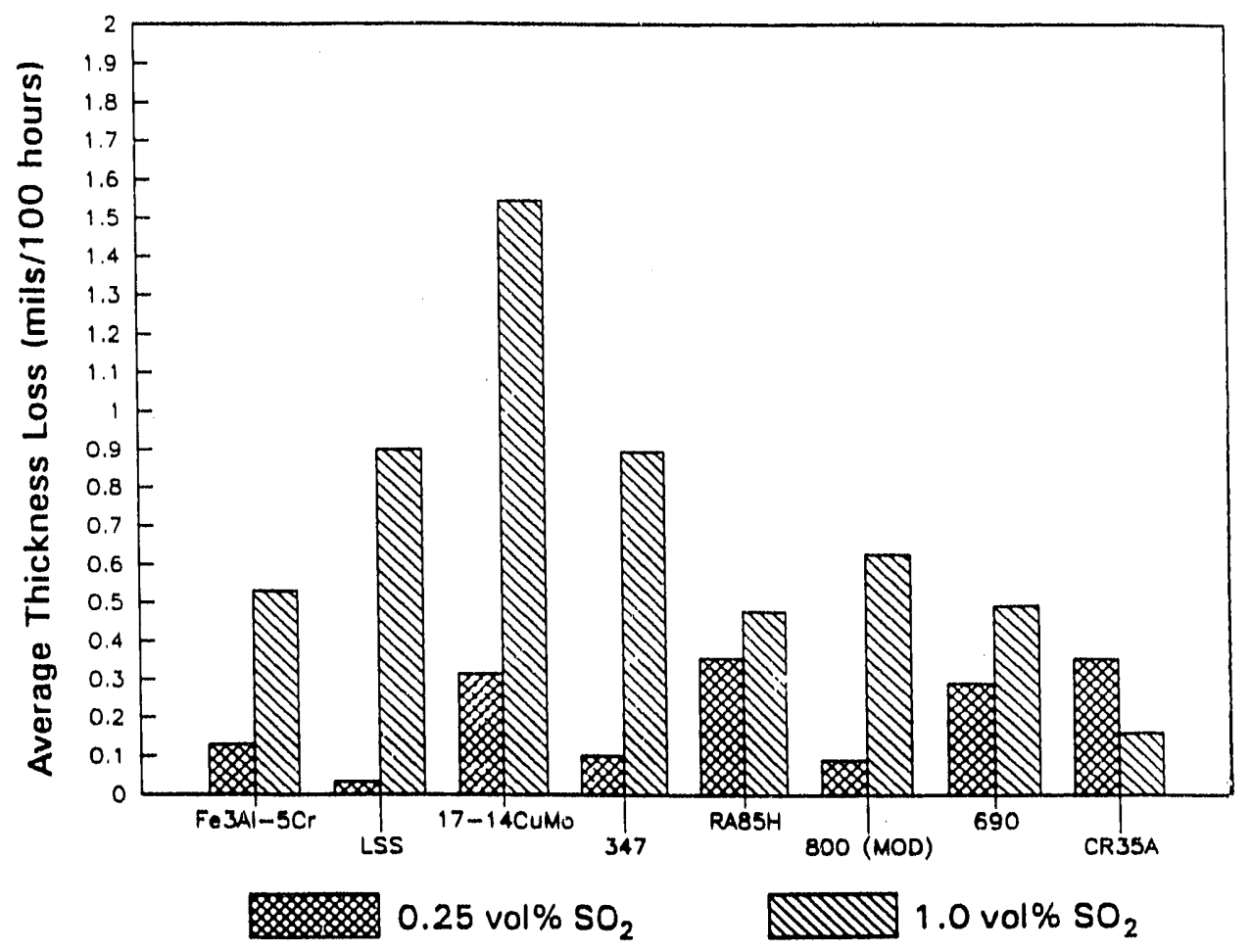

Figure 4.11 Average Thickness Loss Rates of Representative Alloys Coated With Ash Containing 10 wt\% Alkali Sulfates and Exposed at $650^{\circ} \mathrm{C}$ for 800 Hours to Flue Gas Containing Either 0.25 or 1.0 vol\% $\mathrm{SO}_{2}$

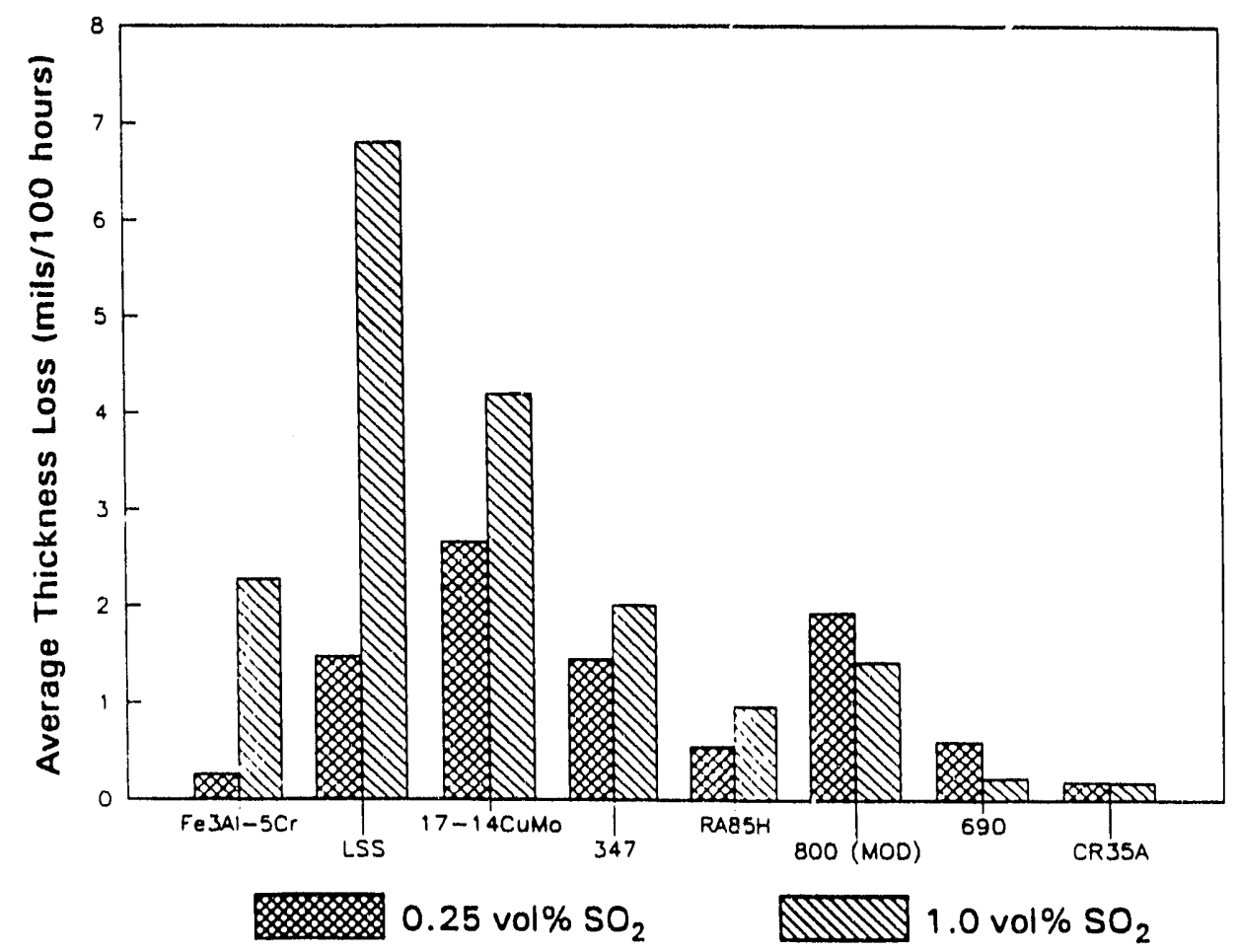

Figure 4.12 Average Thickness Loss Rates of Representative Alloys Coated With Ash Containing 10 wt\% Alkali Sulfates and Exposed at $700^{\circ} \mathrm{C}$ for 800 Hours to Flue Gas Containing Either 0.25 or 1.0 vol\% $\mathrm{SO}_{2}$ 


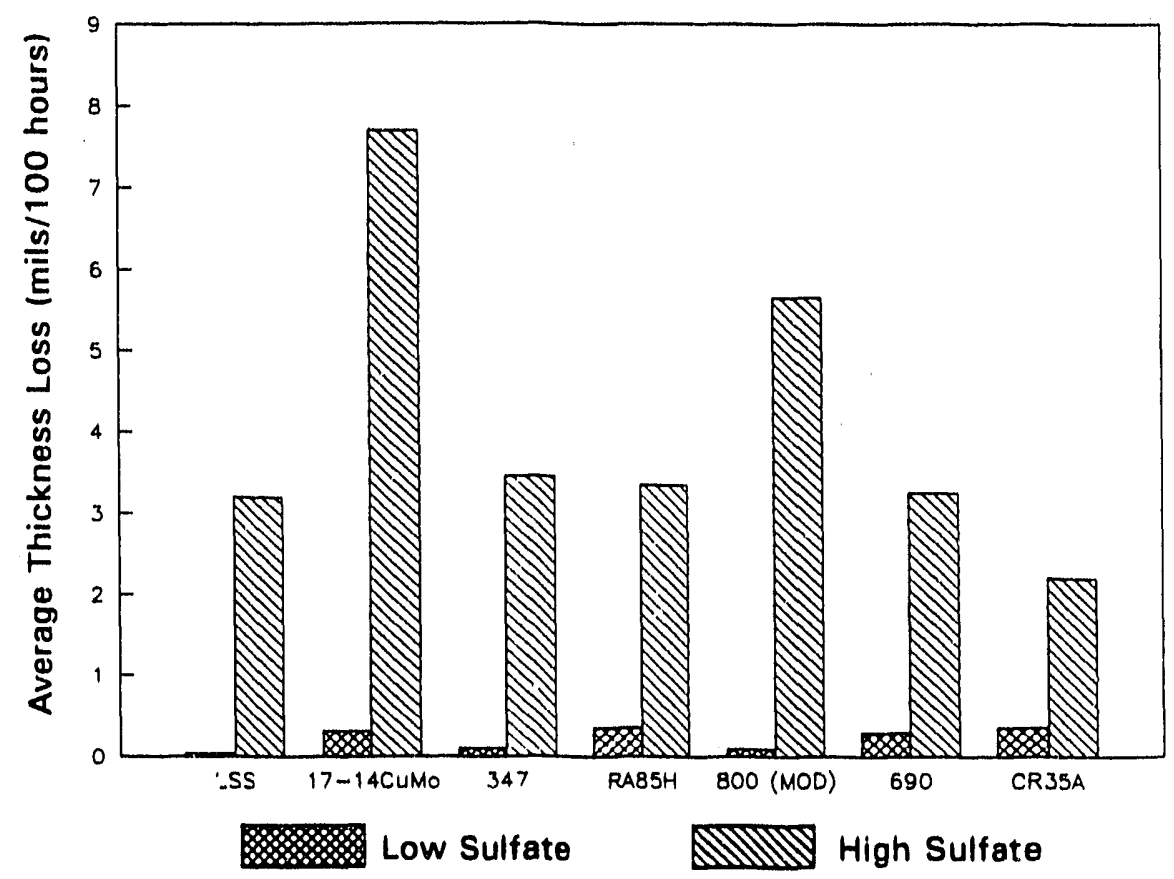

Figure 4.13 Average Thickness Loss Rates of Representative Al loys Coated With Ash Containing Either 10 or 75 wt\% Alkali Sulfates and Exposed at $650^{\circ} \mathrm{C}$ for 200 or 800 Hours Respectively to Flue Gas Containing 0.25 vol\% $\mathrm{SO}_{2}$

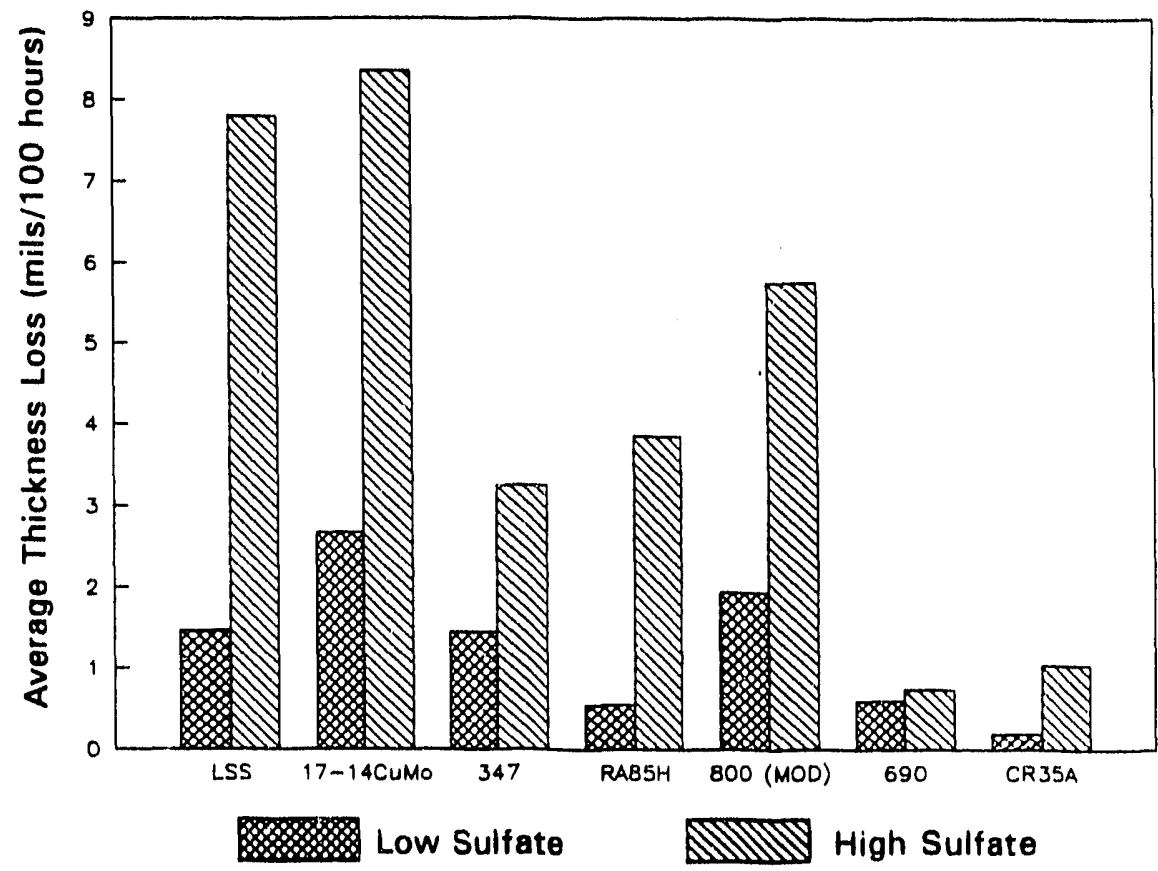

Figure 4.14 Average Thickness Loss Rates of Representative Alloys Coated With Ash Containing Either 10 or 75 wt\% Alkali Sulfates and Exposed at $700^{\circ} \mathrm{C}$ for 200 or 800 Hours Respectively to Flue Gas Containing $0.25 \mathrm{vol}_{\mathrm{SO}} \mathrm{SO}_{2}$ 
The corrosion rate of an alloy after different lengths of exposure time can be used to determine whether passivation is taking place or whether breakaway corrosion is occurring. Figures 4.15 through 4.18 117ustrate how the corrosion rates of various alloys change with exposure time in different environments.

Figures 4.19 through 4.22 present corrosion rates of specimens steamcleaned between exposures and specimens where fresh ash was added between exposures. Summaries of the losses incurred under various conditions are shown in Figures 4.23 through 4.25 . No pattern runs through al1 combinations of alloys and exposure conditions; however, several trends do exist. The corrosion rate increases with exposure time for alloys coated with highsulfate ash (Figures $4.15,4.16$, and 4.23), indicating that either breakaway corrosion is taking place or there was a long induction time for AIT to form initially. The alloys coated with low-sulfate ash generally showed decreasing corrosion rates with time, indicating that a passive layer had formed. However, the coupons coated the lower sulfate ash and exposed to $1.0 \mathrm{vol \%} \mathrm{SO}_{2}$ at $700^{\circ} \mathrm{C}$ show conflicting trends between alloys. This conflicting behavior may indicate that alloys exposed to this set of conditions are on the border between passivity and breakaway corrosion. 


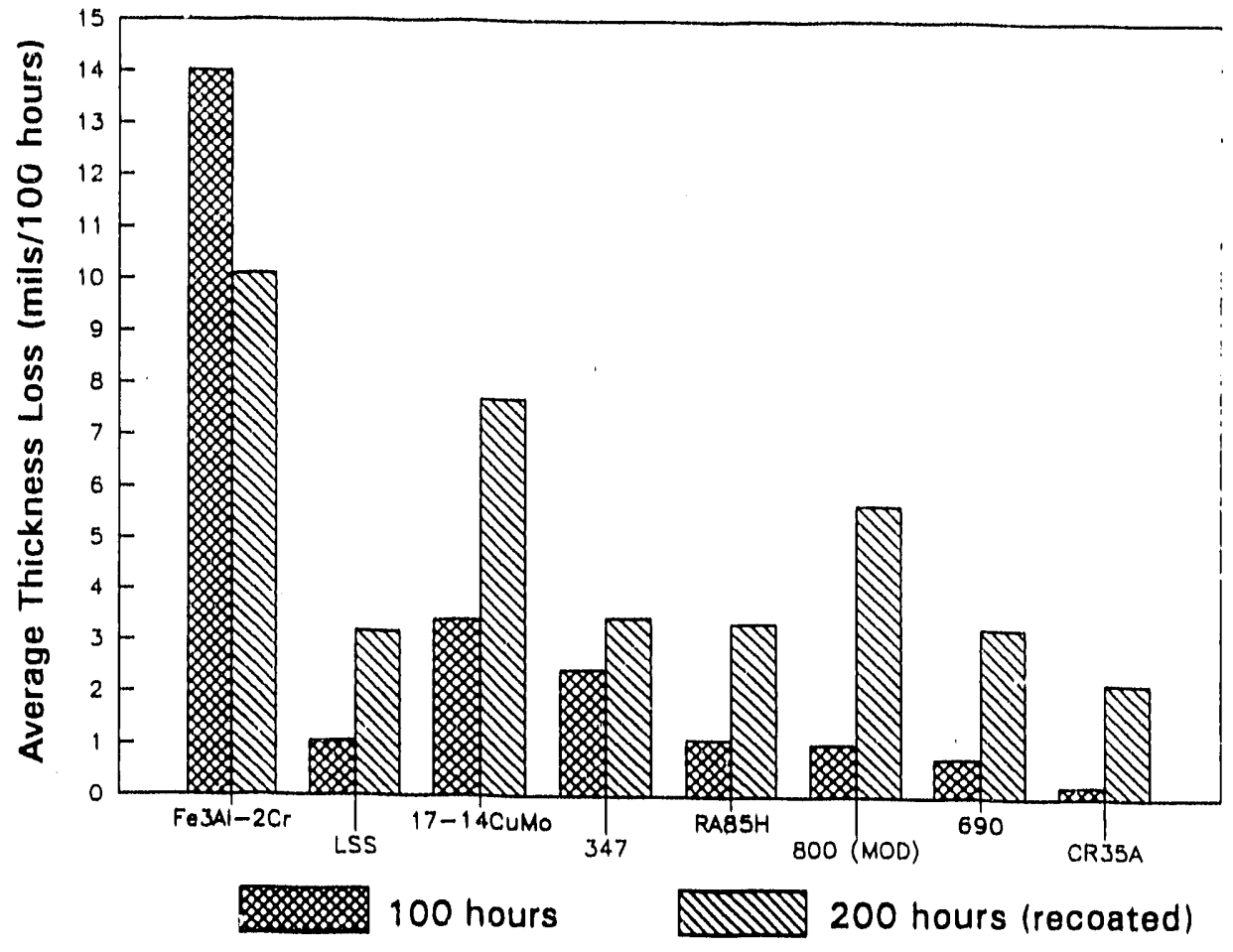

Figure 4.15 Average Thickness Loss Rates of Representative Alloys Coated With Ash Containing 75 wt\% Alkali Sulfates and Exposed at $650^{\circ} \mathrm{C}$ for Either 100 or 200 Hours to Flue Gas Containing 0.25 vol\% $\mathrm{SO}_{2}$

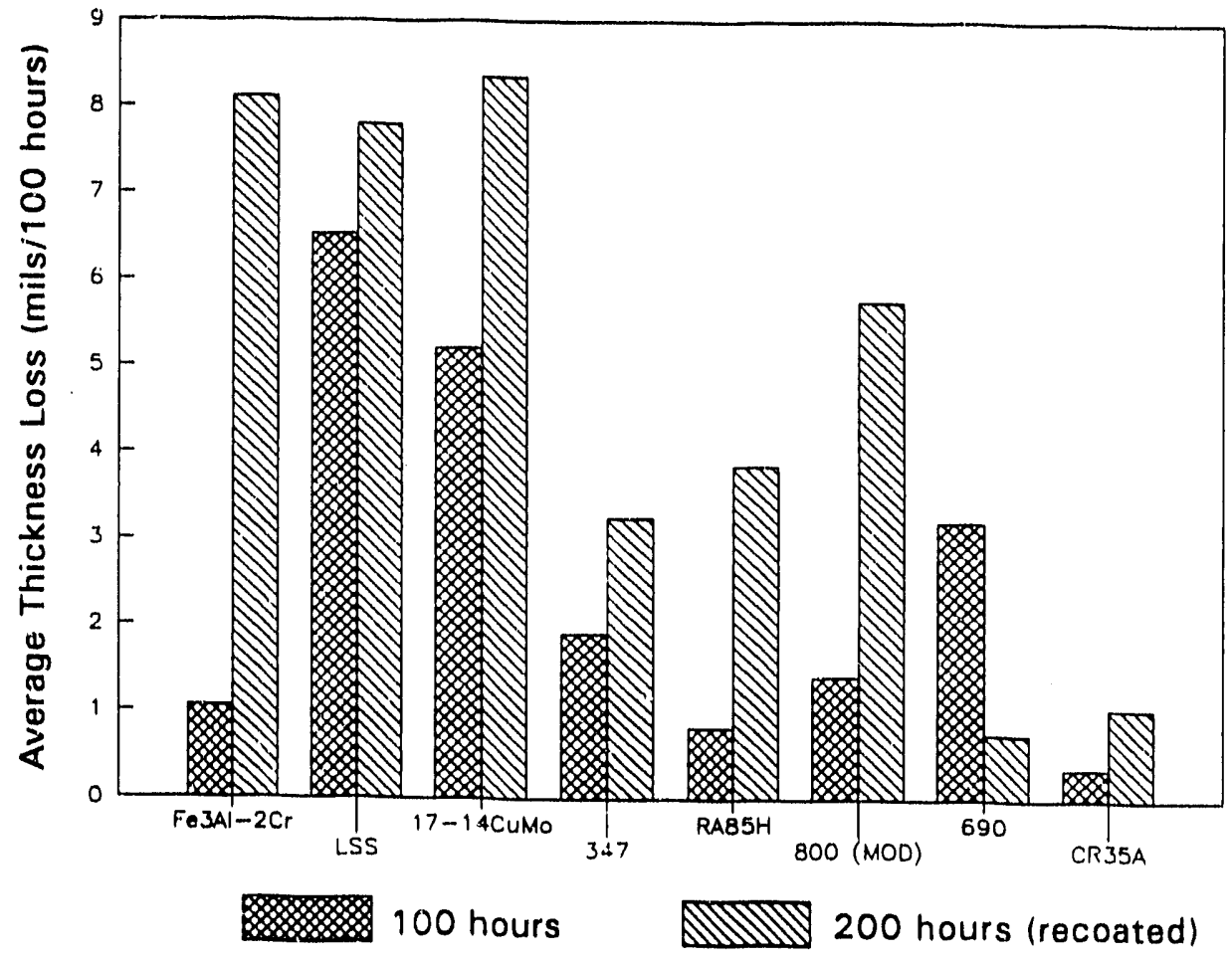

Figure 4.16 Average Thickness Loss Rates of Representative Alloys Coated With Ash Containing 75 wt\% Alkali Sulfates and Exposed at $700^{\circ} \mathrm{C}$ for Either 100 or 200 Hours to Flue Gas Containing 0.25 vol\% $\mathrm{SO}_{2}$ 


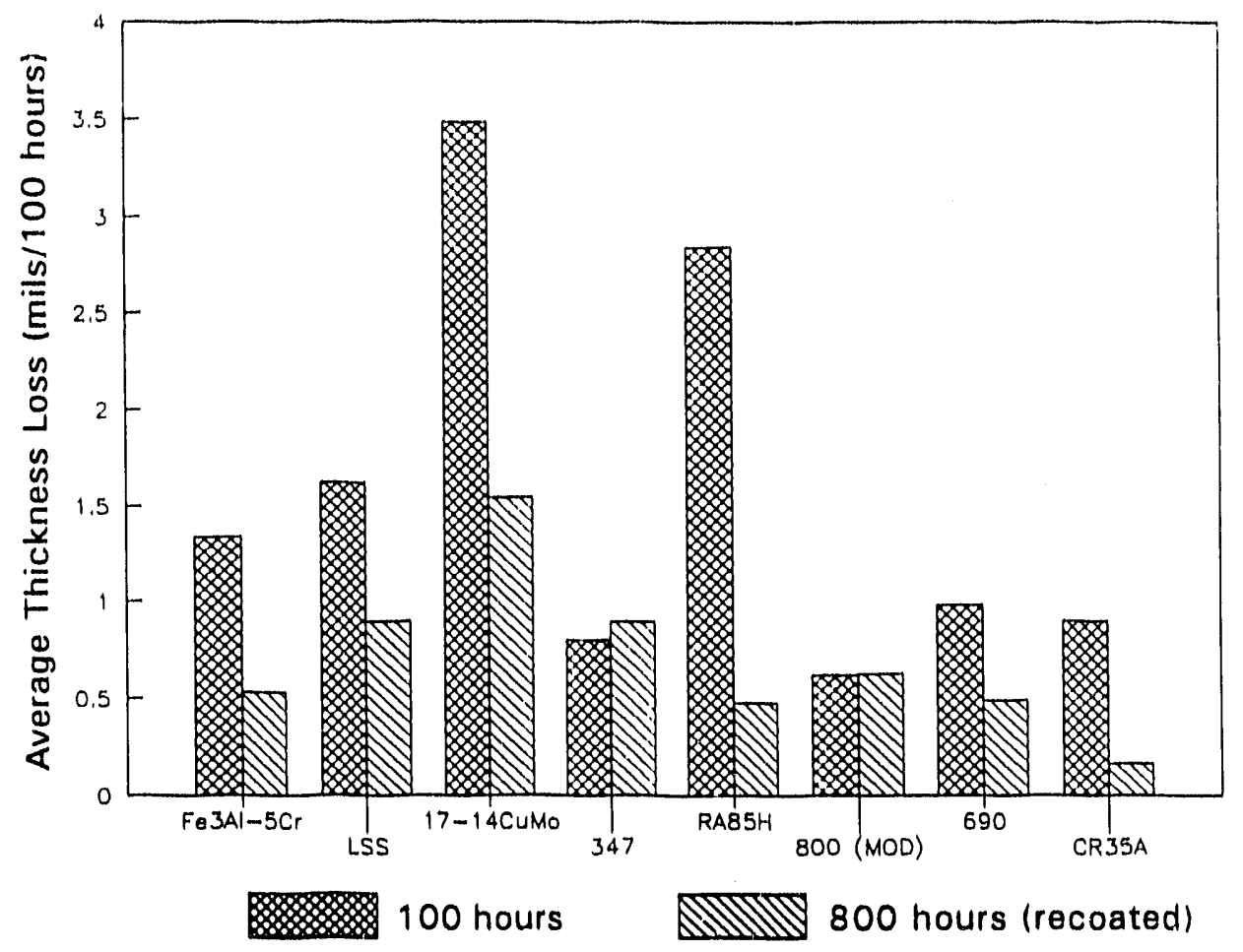

Figure 4.17 Average Thickness Loss Rates of Representative Alloys Coated With Ash Containing 10 wt\% Alkali Sulfates and Exposed at $650^{\circ} \mathrm{C}$ for Either 100 or 800 Hours to Flue Gas Containing 1.0 vol\% $\mathrm{SO}_{2}$

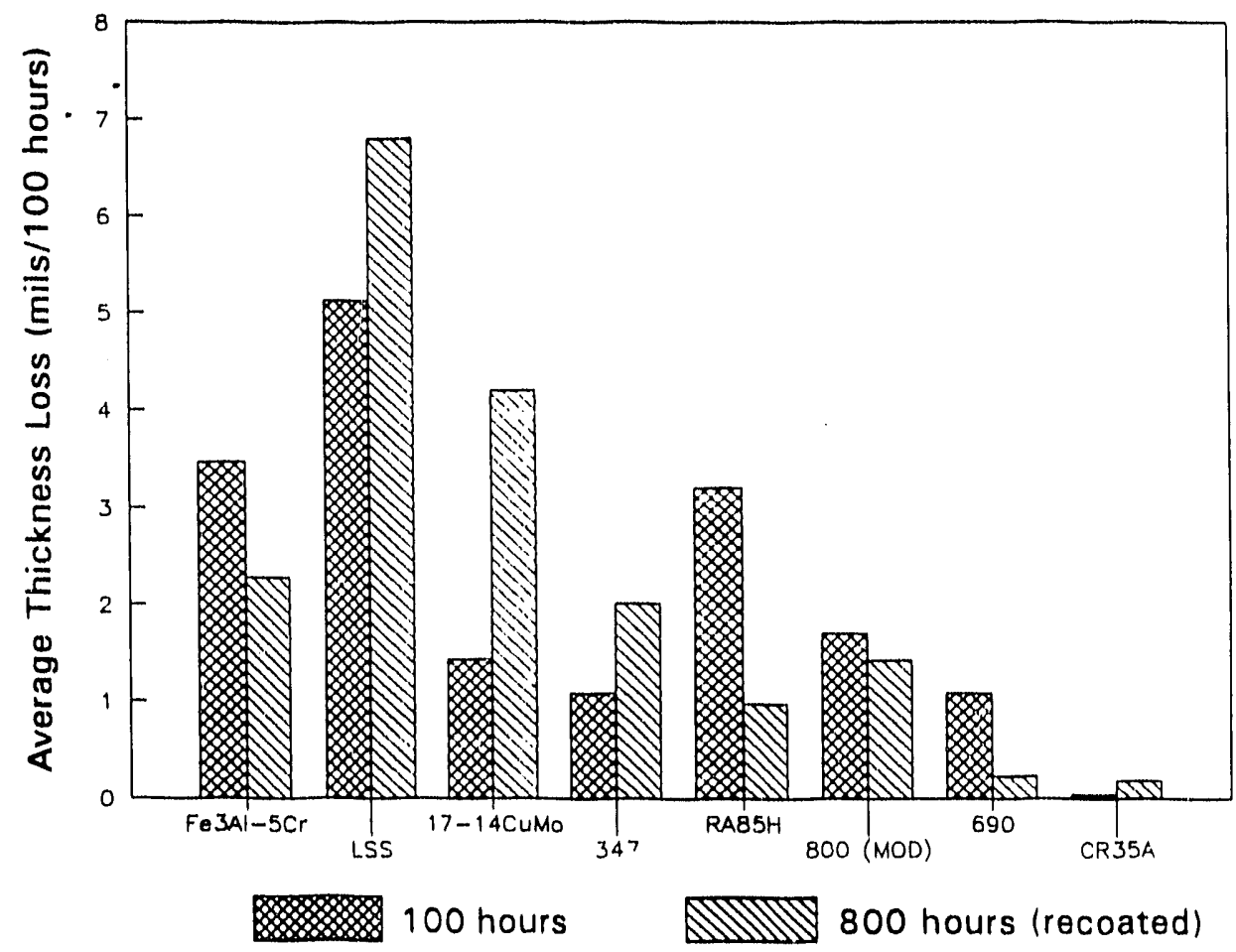

Figure 4.18 Average Thickness Loss Rates of Representative Alloys Coated With Ash Containing $10 \mathrm{wt} \%$ Alkali Sulfates and Exposed at $700^{\circ} \mathrm{C}$ for Either 100 or 800 Hours to Flue Gas Containing 1.0 vol\% $\mathrm{SO}_{2}$ 


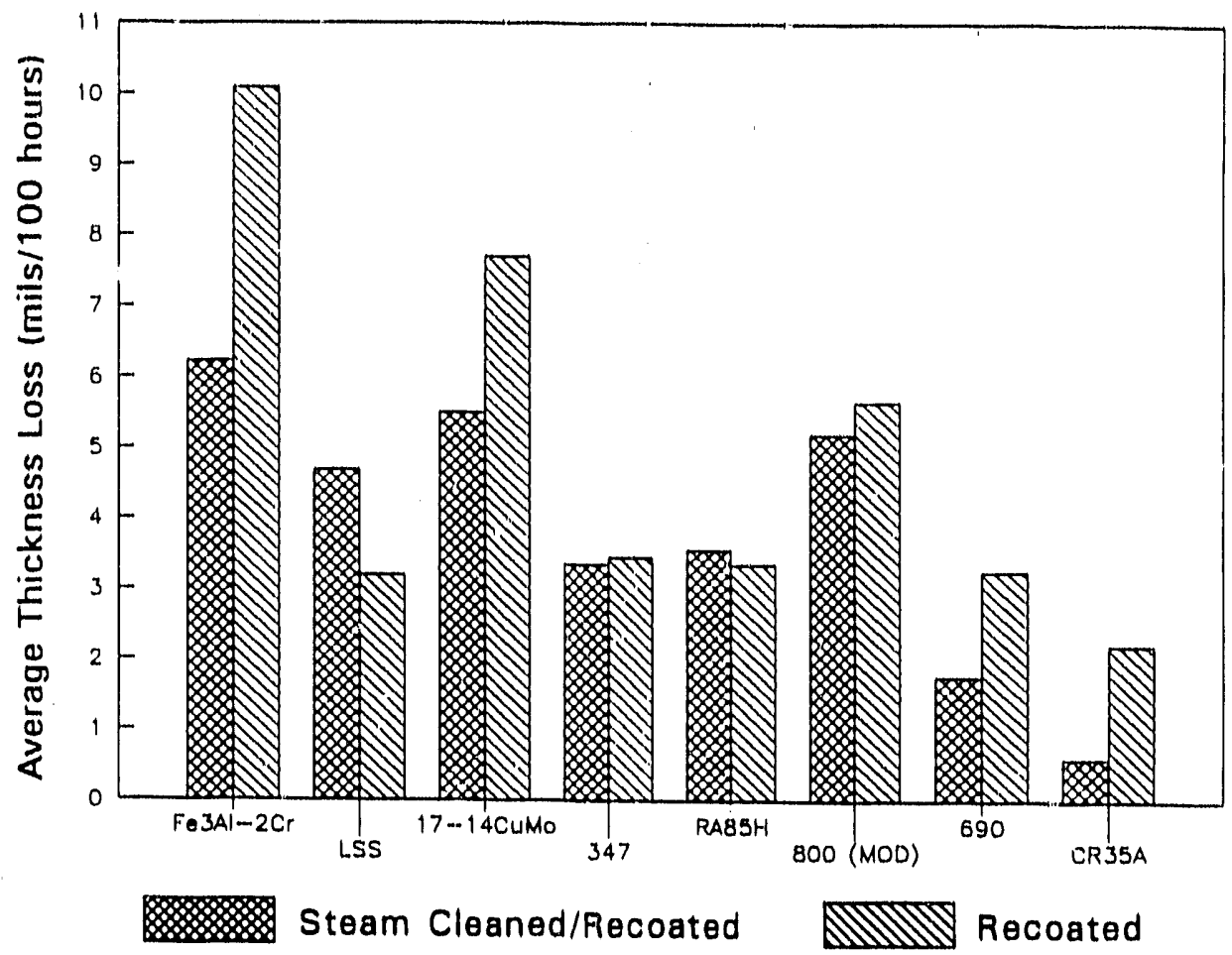

Figure 4.19 Average Thickness Loss Rates of Representative Alloys Coated With Ash Containing 75 wt\% Alkali Sulfates and Exposed at $650^{\circ} \mathrm{C}$ for 200 Hours to Flue Gas Containing 0.25 vol\% $\mathrm{SO}_{2}$

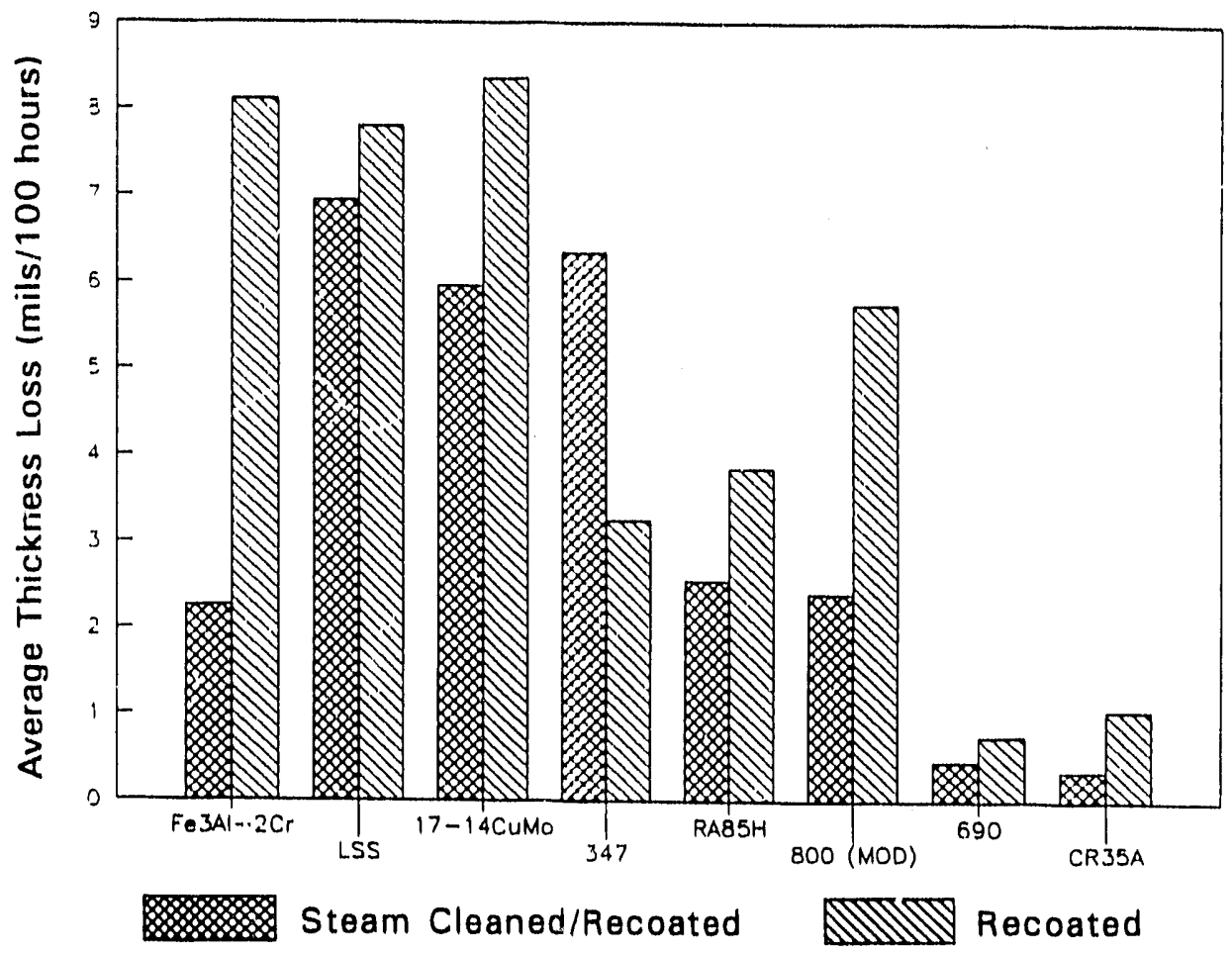

Figure 4.20 Average Thickness Loss Rates of Representative Alloys Coated With Ash Containing 75 wt\% Alkali Sulfates and Exposed at $700^{\circ} \mathrm{C}$ for 200 Hours to Flue Gas Containing $0.25 \mathrm{vol}^{\mathrm{SO} \mathrm{O}_{2}}$ 


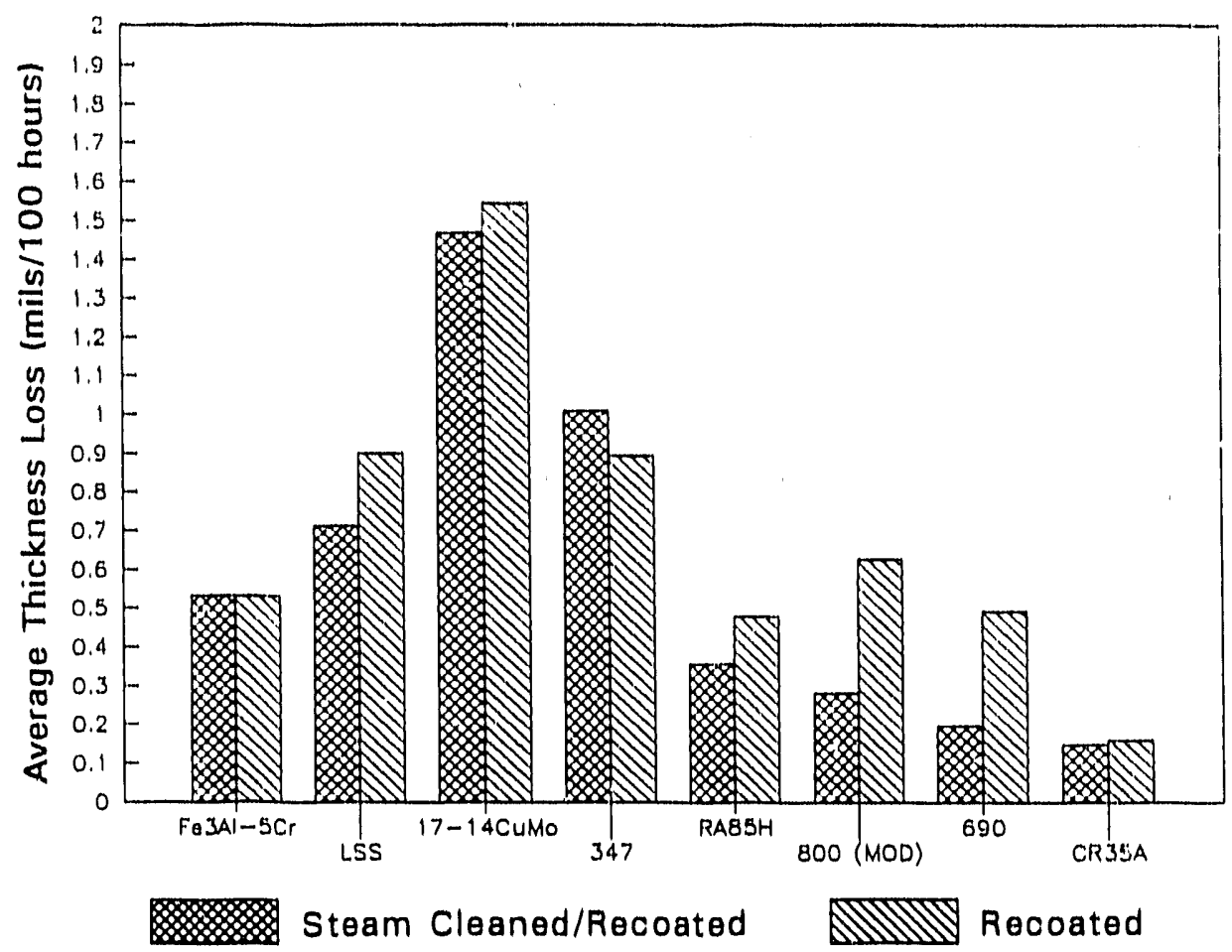

Figure 4.21 Average Thickness Loss Rates of Representative Alloys Coated With Ash Containing $10 \mathrm{wt} \%$ Alkali Sulfates and Exposed at $650^{\circ} \mathrm{C}$ for 800 Hours to Flue Gas Containing 1.0 vol\% $\mathrm{SO}_{2}$

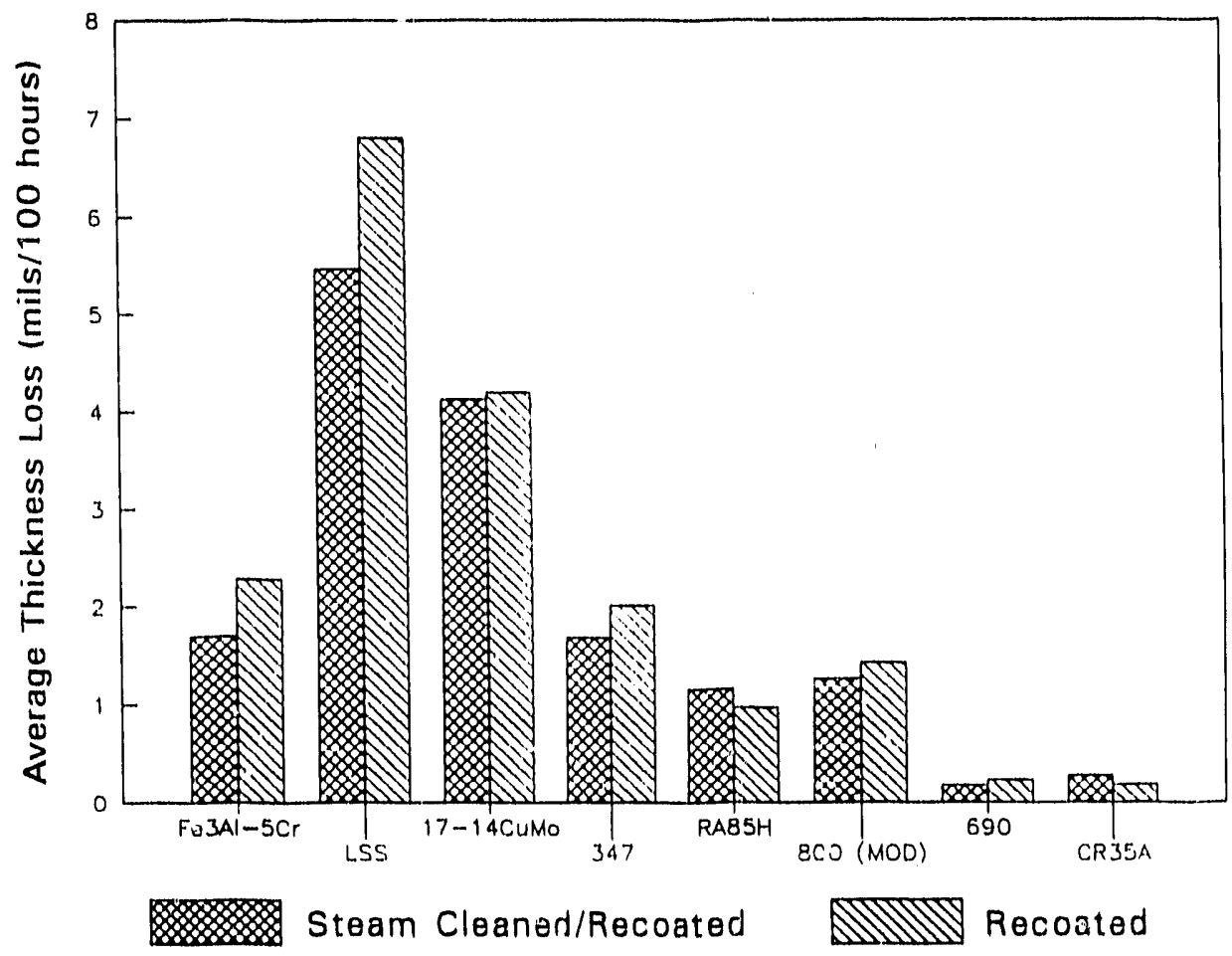

Figure 4.22 Average Thickness Loss Rates of Representative Alloys Coated With Ash Containing $10 \mathrm{wt} \%$ Alkali Sulfates and Exposed at $700^{\circ} \mathrm{C}$ for 800 Hours to Flue Gas Containing 1.0 vol\% $\mathrm{SO}_{2}$ 


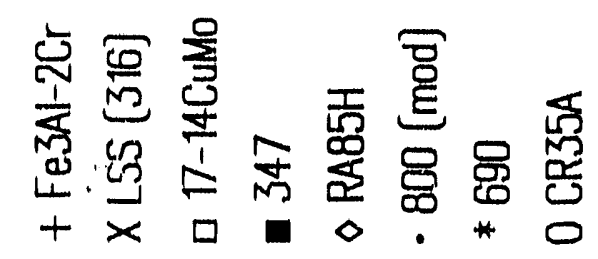

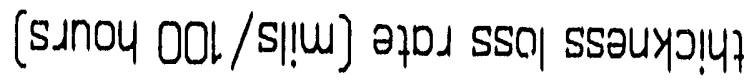




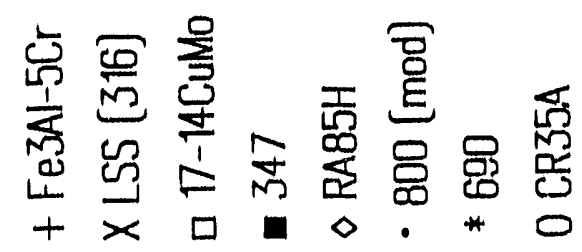

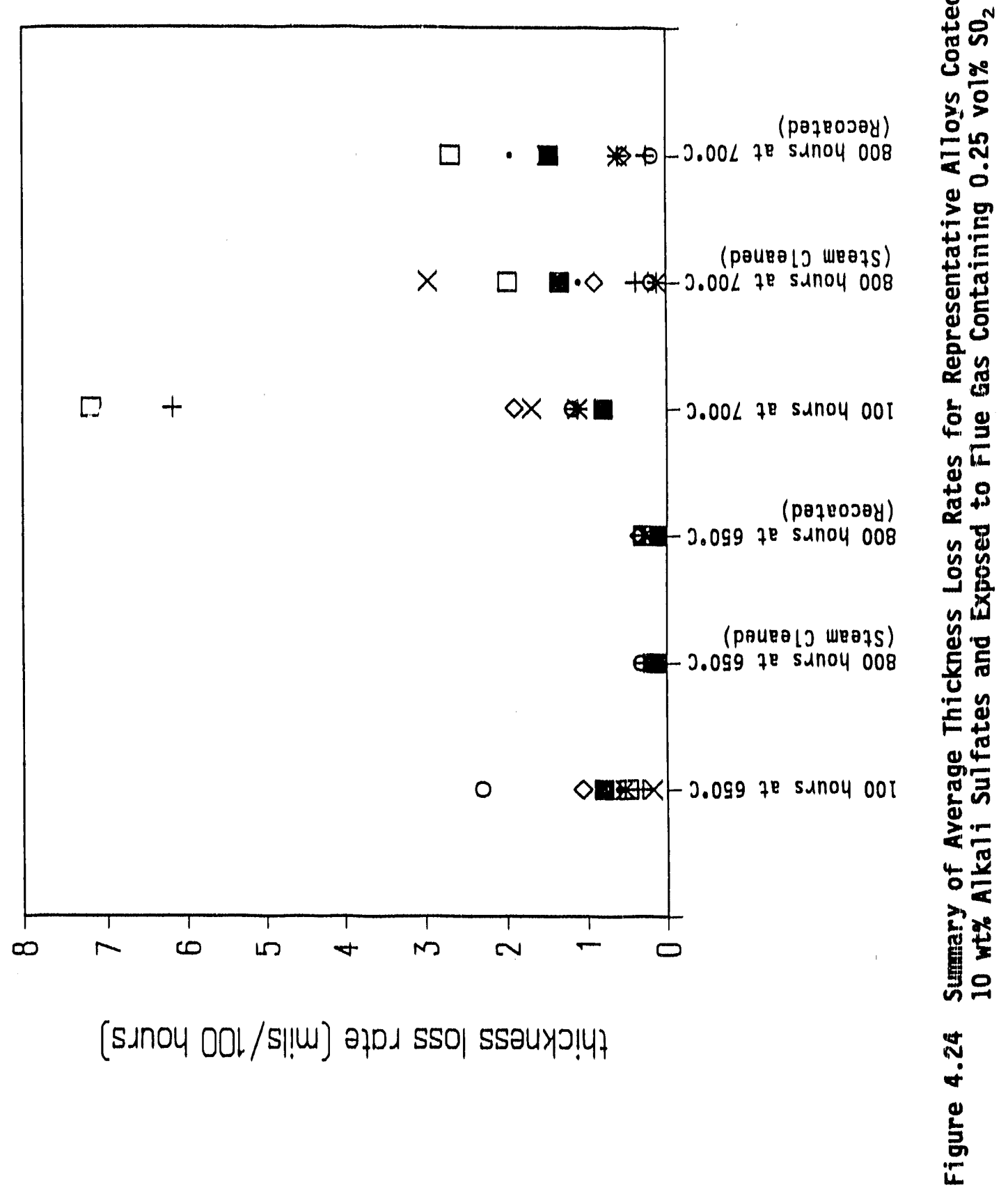



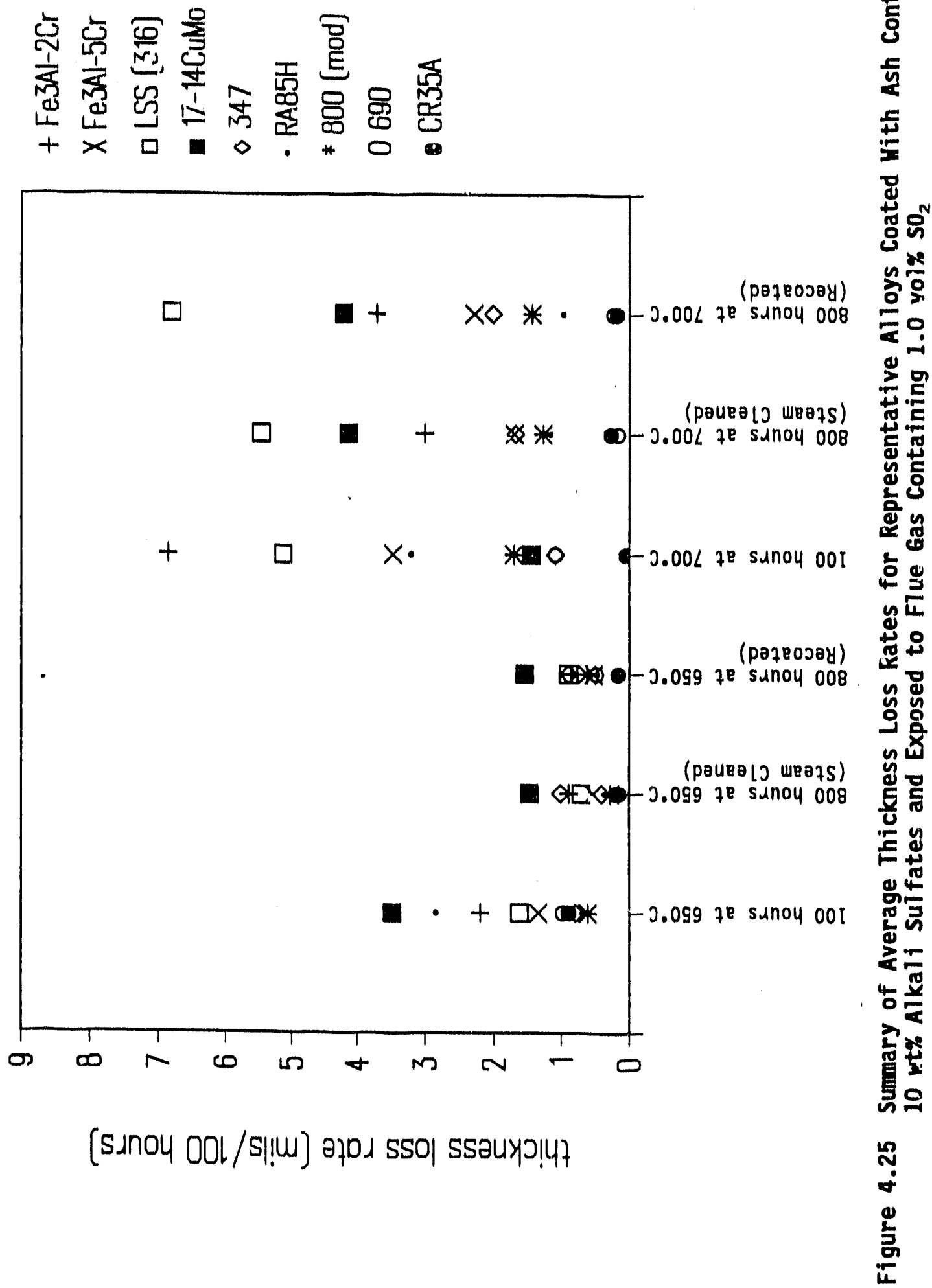


\subsection{MACROSCOPIC EXAMINATION OF EXPOSED SPECIMENS}

Photomacrographs of selected specimens are shown in Figure 4.26. These specimens exhibit the range of corrosion morphologies found during testing. The severtty of attack on these coupons ranges from surface blemishes and discoloration, through isolated pits and patches of corrosion, to uniform wastage. A complete photographtc record of exposed specimens is presented in Appendix $A$. The specimens coated with an ash comprising of 75 w't\% sulfates and exposed to a fiue gas containing 0.25 vol\% $\mathrm{SO}_{2}$ displayed the following corrosion morphologies:

- The modified Type 316 specimen exhibited uniform wastage over its entire surface; small scalloped depressions gave the surface a pebbled appeararce.

- The 690 spectmen suffered deep, trench-11ke pits between sections com-. pletely iree from corrosion. The trenches appeared to be made of numerous small, interlocked pits.

- Corrosion on the tron aluminide specimen left a rough mottled surface.

- The alloys containing chromium for corrosion protection primarlly had a corrosion morphology consisting of regular, shallow, scalloped pits, while the aluminide specimens tended to corrode in uneven, roughened patches.

Specimens exposed to a flue gas containing 0.25 vol\% $\mathrm{SO}_{2}$ while coated with an ash containing 10 wt\% alkali sulfates showed a much lesser degree of corrosion than the specimens coated with a 75 wt\% alkali sulfate ash. In this rather mild environnient, all specimens exhibited surface blemishes and isolated pits only. Increasing the $\mathrm{SO}_{2}$ in the flue gas from 0.25 to 1.0 vol\%, while keeping a coal ash containing 10 wt\% alkali sulfates, moderately increased the wastage rates of the specimens. In each case the corrosion morphologies found are similar to those caused by exposure to a flue gas containing 0.25 vol\% $\mathrm{SO}_{2}$ while coated with an ash containing 75 wt\% alkali sulfates.

- The 690 specimen showed a heavy blemish and the beginnings of the trenchlike pitting morphology found in the specimen exposed to a coal ash containing 75 wt\% alkali sulfates.

- The modified Type 316 specimen suffered uniform corrosion.

- The iron aluminide showed a slightly roughened surface. 


\section{Modified 316}
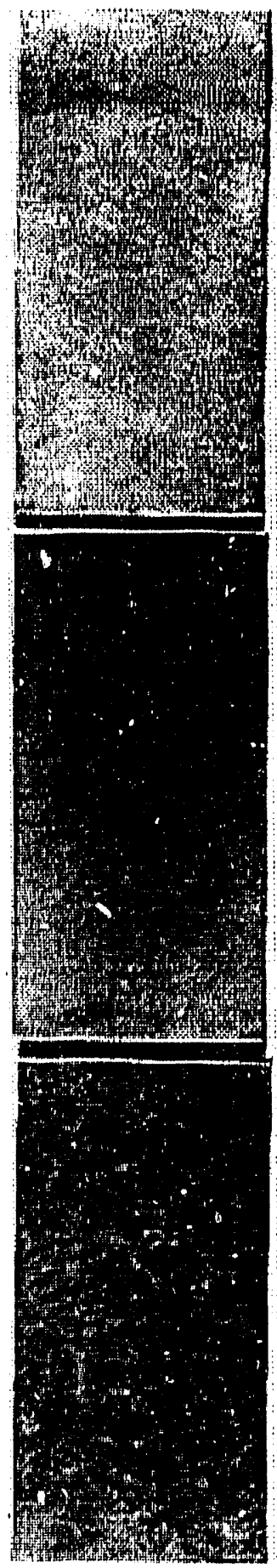

$1-1 / 4 x$
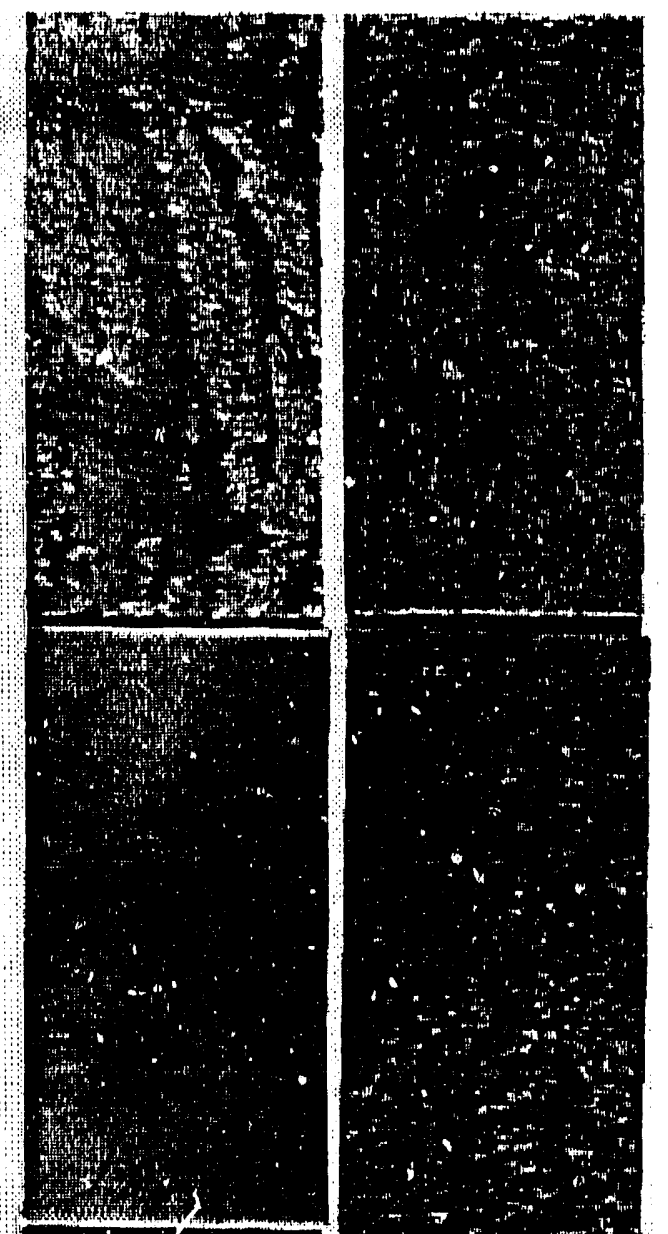

\section{$75 \mathrm{wt} \%$ Sulfate Ash \\ $0.25 \mathrm{vol} \% \mathrm{SO}_{2}$}

$10 \mathrm{wt} \%$ Sulfate Ash

$0.25 \mathrm{vol} \% \mathrm{SO}_{2}$

\section{$10 \mathrm{wt} \%$ Sulfate Ash $1.0 \mathrm{vol} \% \mathrm{SO}_{2}$}

Figure 4.26 Representative Specimens After Exposure to Various Environments 


\subsection{MICROSCOPIC ANALYSIS OF COUPONS AND CORROSION PRODUCTS}

After exposure, the morphology of selected coupons and samples of ash and scale were examined using optical and electron microscopy. The chemical composition of various : amples was also evaluated by an electron microscope equipped with a energy dispersive $x$-ray analysis unit. This unit allowed qualitative chemical determination of elements with an atomic weight $\geq 11$ (the atoinic weight of sodium).

Representative photographs, SEM images, and $x$-ray maps of the corroded specimens are presented in Figures 4.27 through 4.43. Specimens displayed in Figures 4.27 through $4.30,4.32$, and 4.33 were not cleaned after exposure. These specimens were coaled with a $10 \mathrm{wt \%}$ alkali sulfate coal ash and exposed to flue gas containing 1.0 vol\% $\mathrm{SO}_{2}$ at $700^{\circ} \mathrm{C}$ for 200 hours. A 690 specimen exposed for 800 hours to this same environment is shown in Figures 4.34 and 4.35. Figures 4.27 and 4.28 show an iron aluminide alloyed with 2 wt\% chromium. This alloy was exposed to flue gas containing 0.25 vol\% $\mathrm{SO}_{2}$ at $700^{\circ} \mathrm{C}$ for 200 hours while coated with an ash containing 75 wt\% alkali sulfates. Finally (for comparison), Figures 4.39 and 4.40 show a sample of Type $310 \mathrm{Nb}$ exposed for 16,000 hours in a PC-fired boiler.

A section through a corroded $17-14$ CuMo coupon at $700^{\circ} \mathrm{C}$ is shown in Figures 4.27 and 4.28 . The corroding surface in Figure 4.27 shows a smooth interface between metal and ash, with no indications of subsurface enrichment, intergranular attack, or the formation of subsurface sulfides and oxides. To confirm this, the maps of chemical concentration in Figure 4.28 do not show any depletion or enrichment of the primary alloying elements or any subsurface concentrations of sulfur. An interesting feature of the ash is the regions of

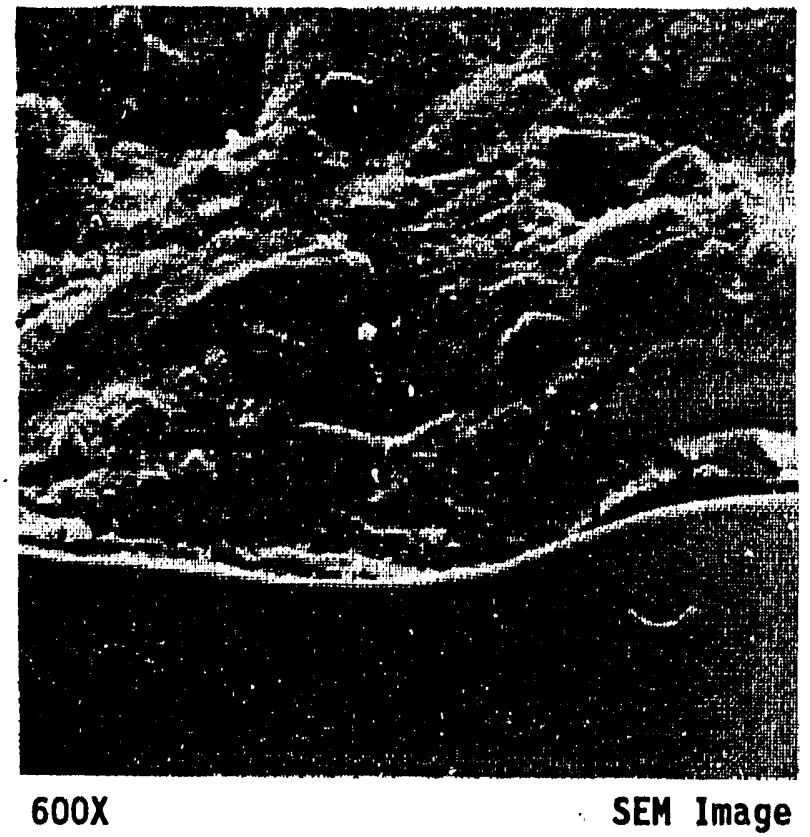

Figure 4.27 Corroded Surface of a 17-14 CuMo Specimen Coated With Ash Containing 10 wt\% Alkali Sulfates After Exposure for 200 Hours at $700^{\circ} \mathrm{C}$ to Flue Gas Containing 1.0 vol\% $\mathrm{SO}_{2}$. (Top area of image shows ash coating; bottom area is specimen.) 

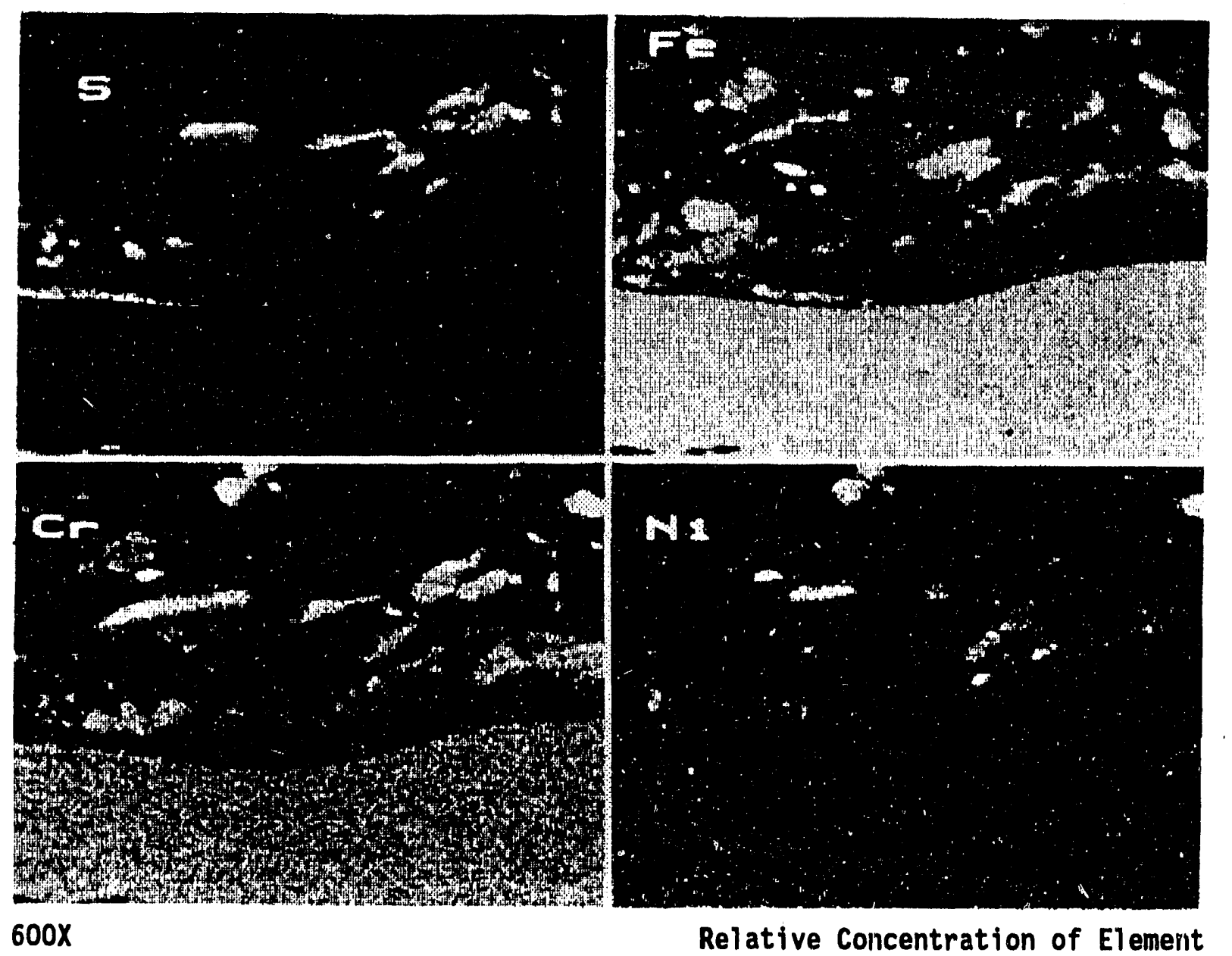

Figure 4.28 X-Ray Map of Corroded Surface of 17-14 CuMo Specimen Coated With Ash Containing 10 wt\% Alkali Sulfates After Exposure for 200 Hours at $700^{\circ} \mathrm{C}$ to Flue Gas Containing 1.0 yol\% $\mathrm{SO}_{2}$ 
high sulfur and either high nickel or high chromium. These may be pockets of chromium and nickel sulfide which have precipitated in the ash layer. The chromium level in this alloy was apparently too low to form a protective barrier against molten AIT attack, and the alloy was simply fluxed away with no subsurface interactions. Examination of specimens exposed for 800 hours did not show any significant differences in microstructure from the specimen just described, supporting the hypothesis that this alloy did not contain enough chromium to passivate.

Figures 4.29 and 4.30 show a cross-section of RA85H coated with ash after exposure for 200 hours at $700^{\circ} \mathrm{C}$. As shown in Figure 4.29 , the corroded surface is jagged, with intergranular attack and subsurface penetration taking place. Chromium appears to have been depleted from the alloy to form a chromium-rich layer along grain boundaries and at the interface, where it formed sulfides and oxides. Near the interface, where chromium depletion has taken place, nickel has been selectively enriched. In several locations high concentrations of nickel and sulfur together would seem to indicate the formation of nickel sulfides. The high concentration of sulfur at the interface, combined with areas that seem to be chromium and nickel sulfides, raises the possibility that an oxidation-sulfidation reactions are taking place in addition to fluxing by molten AIT. The iron in this alloy is removed by transport across the chromium- and sulfur-rich zone into the ash. Figure 4.31 displays an RA85H specimen which has been exposed for 800 hours at $700^{\circ} \mathrm{C}$. Intergranular attack has taken place to a point where grains are beginning to fall out.

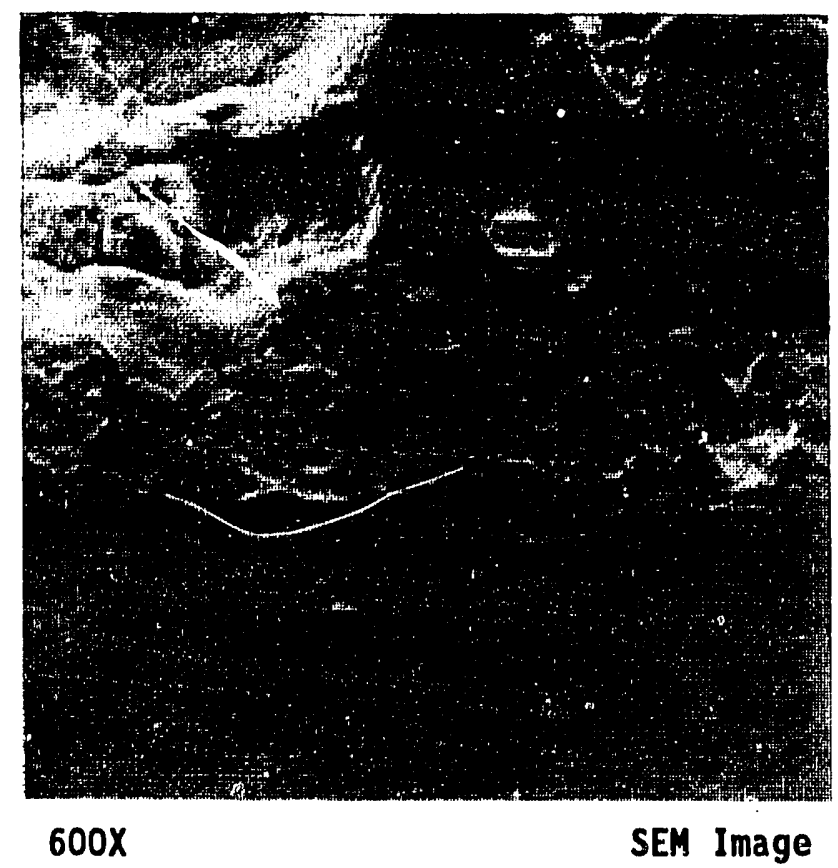

Figure 4.29 Corroded Surface of RA85H Specimen Coated With Ash Containing 10 wt\% Alkali Sulfates After Exposure for 200 Hours at $700^{\circ} \mathrm{C}$ to Flue Gas Containing 1.0 vol\% $\mathrm{SO}_{2}$. (Top area of image shows ash coating; bottom area is specimen.) 

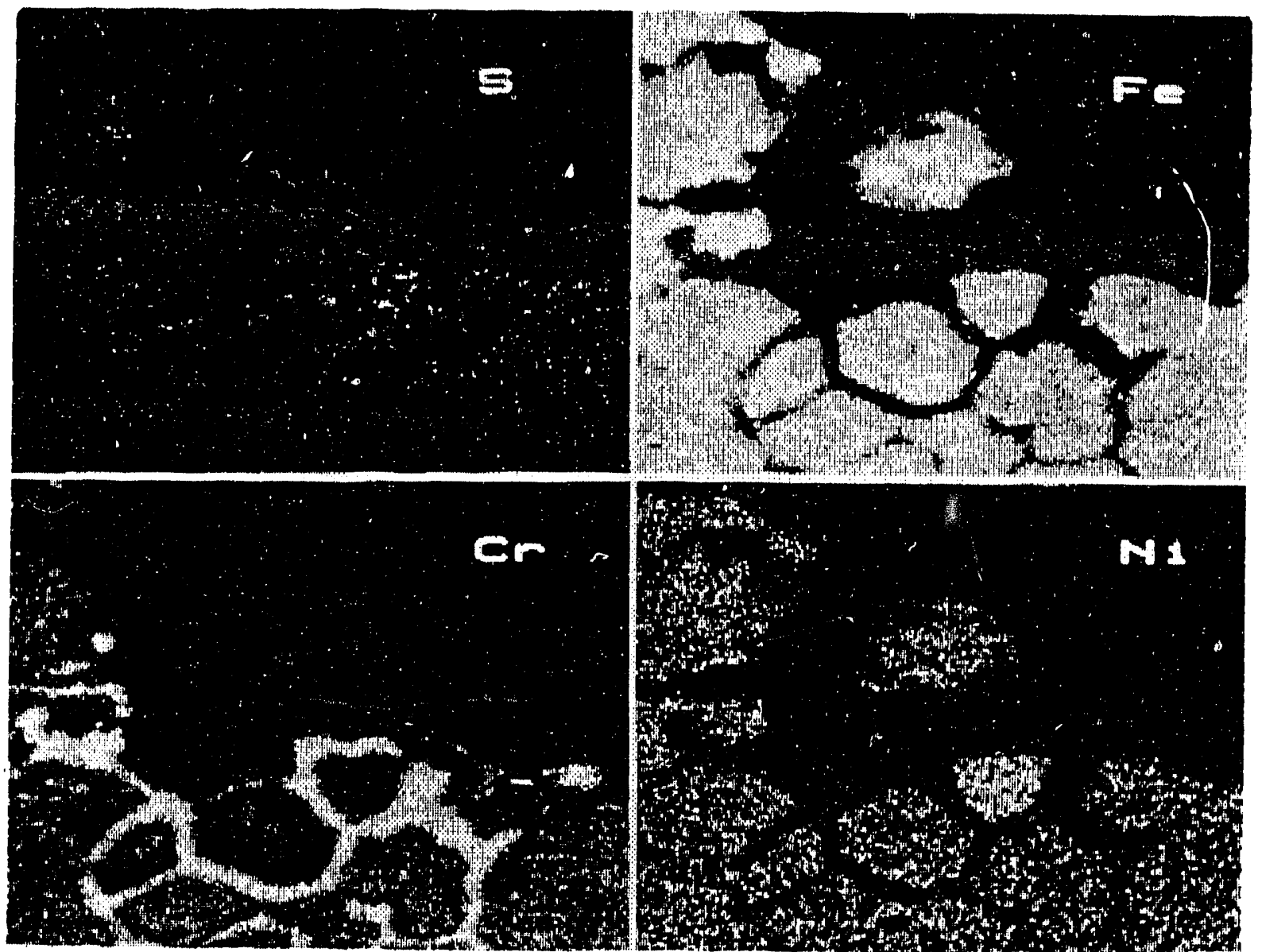

$600 x$

Relative Concentration of Element

Figure 4.30 X-Ray Map of Corroded Surface of RA85H Specimen Coated With Ash Containing 10 wt\% Alkali Sulfates After Exposure for 200 Hours at $700^{\circ} \mathrm{C}$ to Flue Gas Containing 1.0 vol\% $\mathrm{SO}_{2}$ 


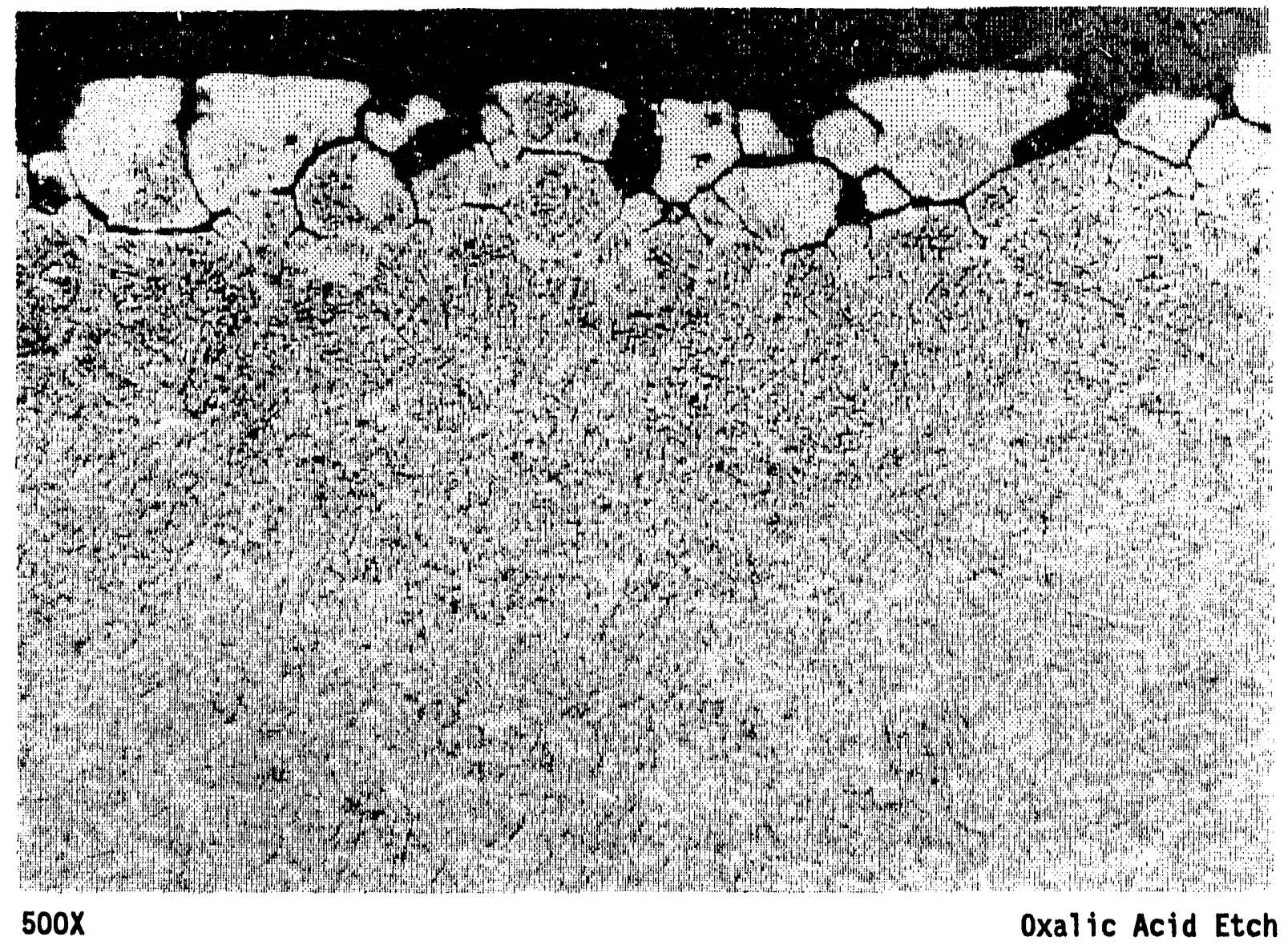

Figure 4.31 Corroded Surface of RA85H Specimen Coated With Ash Containing 10 wt\% Alkali Sulfates After Exposure for 800 Hours at $700^{\circ} \mathrm{C}$

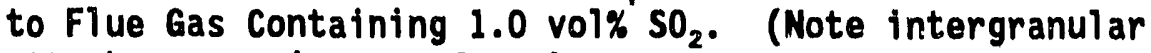
attack on specimen surface.) 
A section through a corroding CR35A coupon exposed at $700^{\circ} \mathrm{C}$ for 200 hours is displayed in Figures 4.32 and 4.33 . As Figure 4.32 shows, the metal surface is untouched except for one small blemish. The blemish seems to be enriched in chromium and sulfur in sections, while depleted in chromium in other sections. One explanation for this morphology is that the blemish was formed by chromium sulfidation. In areas of high oxygen activity, the sulfides were oxidized, recycling the sulfur into $\mathrm{SO}_{2}$ and $\mathrm{SO}_{3}$. Around and atop the blemish, chromium has depleted from the alloy to form a thin, dense layer. An iron-rich band has formed above this layer, and a small quantity of chromium has diffused into it.

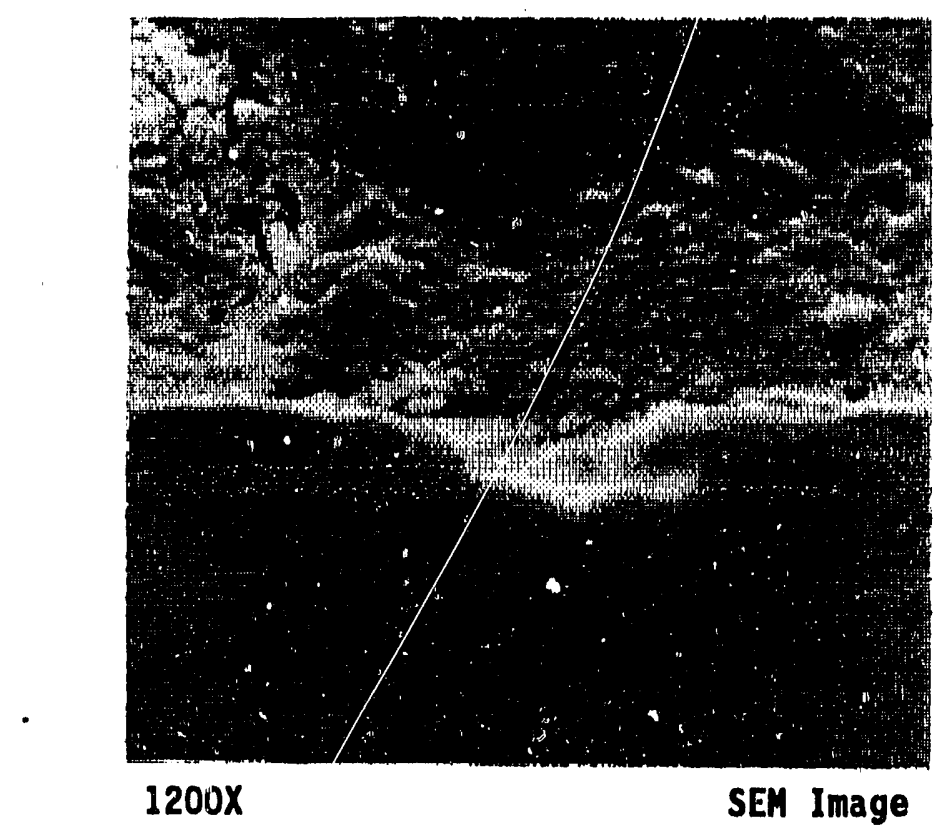

Figure 4.32 Corroded Surface of CR35A Specimen Coated With Ash Containing 10 wt\% Alkali Sulfates After Exposure for 200 Hours at $700^{\circ} \mathrm{C}$ to Flue Gas Containing 1.0 vol\% $\mathrm{SO}_{2}$. (Note beginning of pit in middle of photograph.)

The corroded surface of a monolithic 690 specimen after exposure at $700^{\circ} \mathrm{C}$ is shown in Figures 4.34 and 4.35 , with an accompanying $x$-ray map of chemical composition shown in Figure 4.36. This specimen has been exposed for 800 hours, rather than the 200 hours of exposure for the previously shown specimens. As illustrated in both the optical photomicrograph and SEM image, the specimen is being attacked by a sulfidation and oxidation front moving down from the surface, depleting the surface metal of chromium. This depletion destroys the passive chromium oxide scale and allows AIr attack to occur. The attack morphology seen on this specimen could be the same form of attack seen on the CR35A specimen shown in Figures 4.32 and 4.33. This form of attack is only noticeable in higher-alloy specimens exposed for longer than 100 hours. 


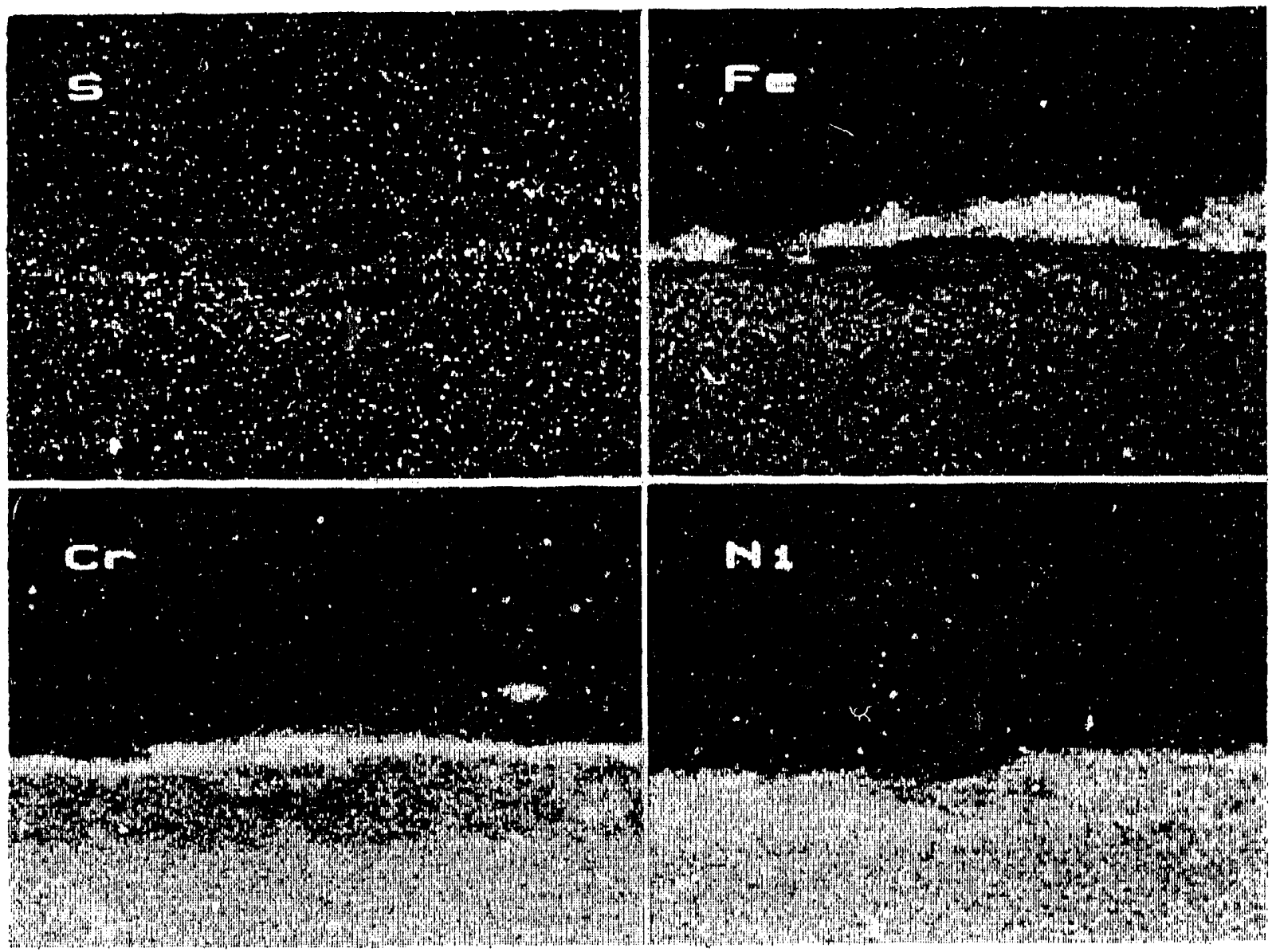

Figure 4.33 X-Ray Map of Corroded Surface of CR35A Specimen Coated With Ash Containing 10 wt\% Alkali Sulfates After Exposure for 200 Hours at $700^{\circ} \mathrm{C}$ to Flue Gas Containing 1.0 vol\% $\mathrm{SO}_{2}$ 

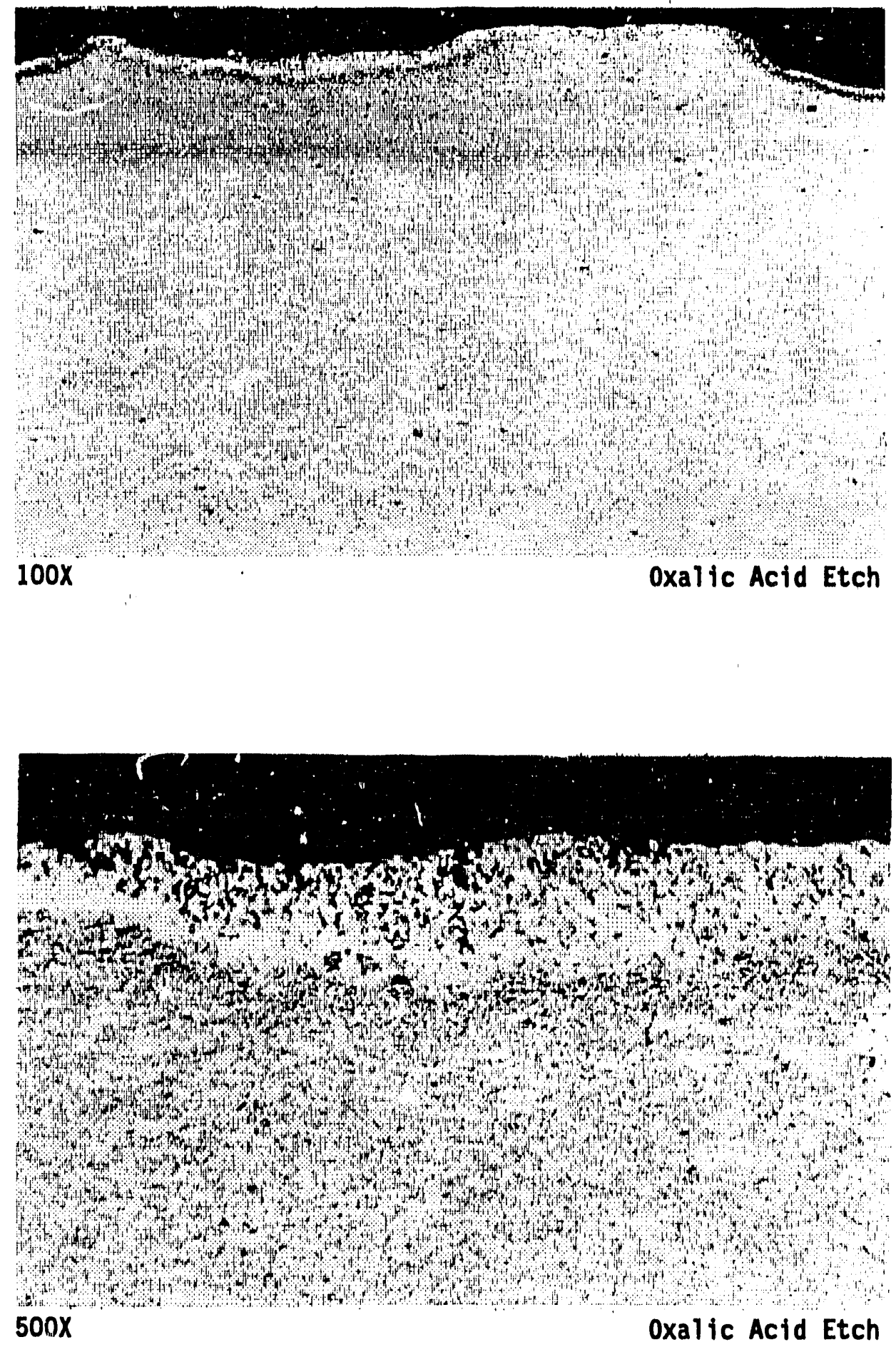

Figure 4.34 Corroded Surface of 690 Specimen Coated With Ash Containing 10 wt\% Alkali Sulfates After Exposure for 800 Hours at $700^{\circ} \mathrm{C}$ to Flue Gas Containing 1.0 vol\% $\mathrm{SO}_{2}$. (Note chromium depletion and oxidation/sulfidation on specimen surface.) 


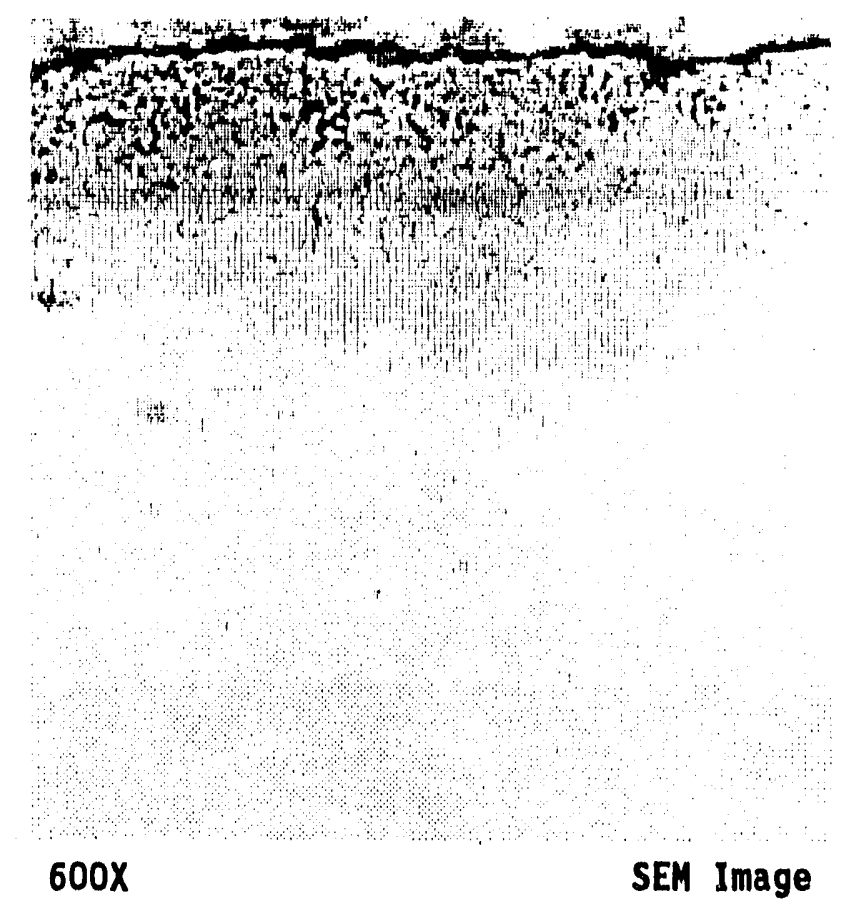

Figure 4.35 Corroded Surface of 690 Specimen Coated With Ash Containing 10 wt\% Alkali Sulfates After Exposure for 200 Hours at $700^{\circ} \mathrm{C}$ to Flue Gas Containing 1.0 vol\% $\mathrm{SO}_{2}$. (Note cliromium depletion and oxidation/sulfidation on specimen surface.)

A pit in iron aluminide, filled with corrosion products, is shown in Figure 4.37, with an accompanying $x$-ray map of the metal and deposit shown in Figure 4.38. The deposit appears to have a lamellar structure, with a thin layer containing a high concentration of sulfur, and a iron-rich region as the outermost layer. There appears to be no depletion in the alloy itself, in contrast to the stainless steels and nickel-based alloys. Rather, the corrosion front appears to be a sharp demarcation between corroded material and sound alloy.

For comparison with the laboratory specimens, an Alloy $310 \mathrm{Nb}$ tube, which was exposed for 16,000 hours at the Tennessee Valley Authority's Gallatin Station, is shown in Figures 4.39 and 4.40 [5] . The corrosive attack on this specimen is fully developed and may be assumed to have reached steady state conditions. As illustrated in Figure 4.40, four attack mechanisms are occurring: chromium has been depleted from the area around the grain boundaries, subsurface metal has been depleted of chromium and enriched in nickel, chromium sulfides have formed in the subsurface metal, and AIT attack has occurred. All of these attack mechanisms are found on various specimens exposed during laboratory testing, indicating that exposures conducted under laboratory conditions provide similar conditions to those found in operating utility boilers. 

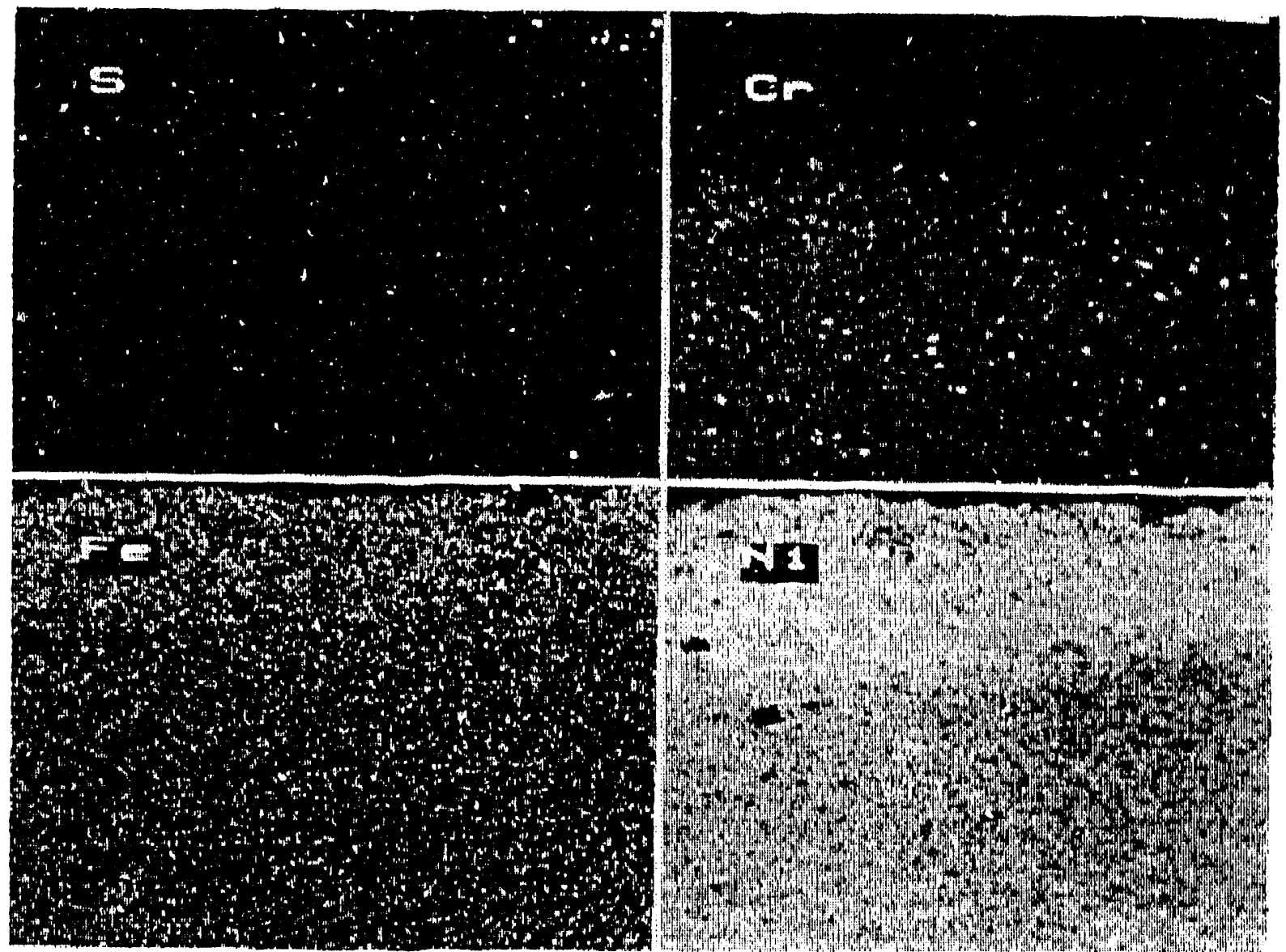

Figure 4.36 X-Ray Map of Corroded Surface of 690 Specimen Coated With Ash Containing 10 wt\% Alkali Sulfates After Exposure for 200 Hours at $700^{\circ} \mathrm{C}$ to Flue Gas Containing 1.0 vol\% $\mathrm{SO}_{2}$ 


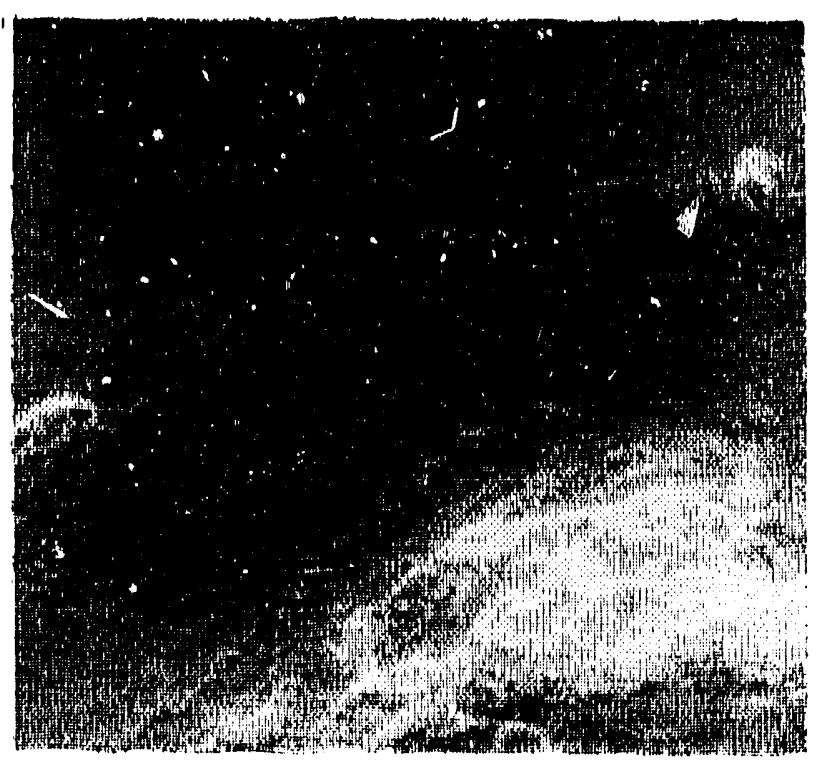

Figure 4.37 Corroded Surface of Iron Aluminide Specimen Containing 2\% Chromium Chremium Coated With Ash Containing 10 wt\% Alkali Sulfates After Exposure for 200 Hours at $700^{\circ} \mathrm{C}$ to Flue Gas Containing 1.0 vol\% $\mathrm{SO}_{2}$. (Note pit growing from specimen surface at bottom of photograph.) 


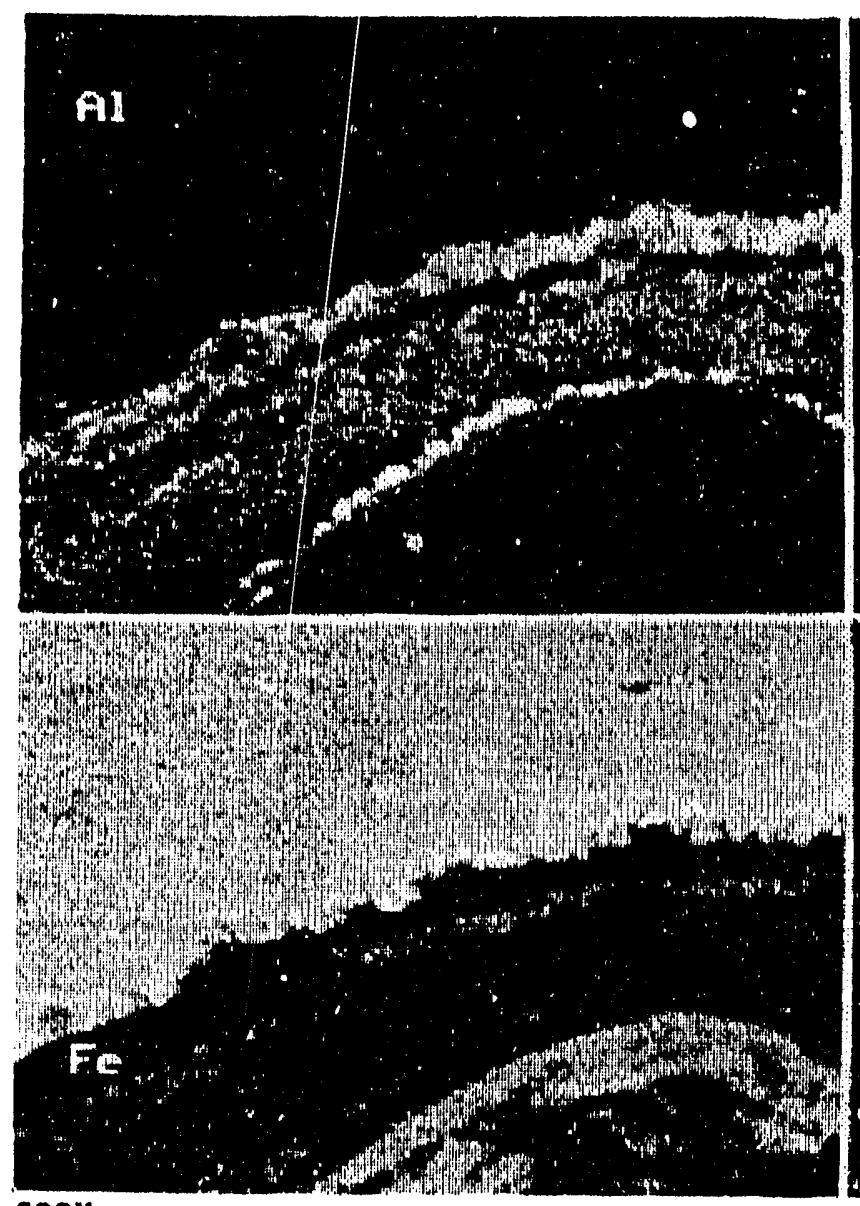

$600 x$
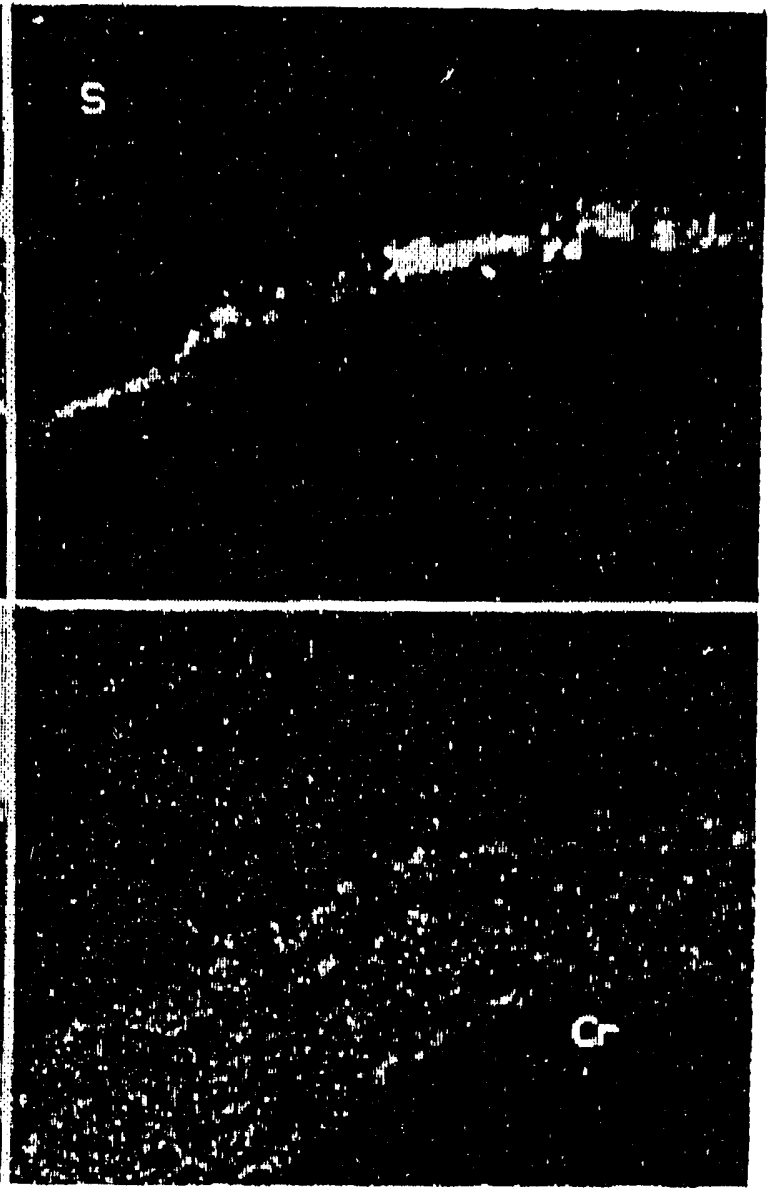

Relative Concentration of Element

Figure 4.38 X-Ray Map of Corroded Surface of Iron Aluminide Specimen Containing 2\% Chromium Coated With An Ash Containing 10 wt\% Alkal1 Sulfates After ixposure for 200 Hours at $700^{\circ} \mathrm{C}$ to Flue Gas Containing 1.0 vol\% $\mathrm{SO}_{2}$ 


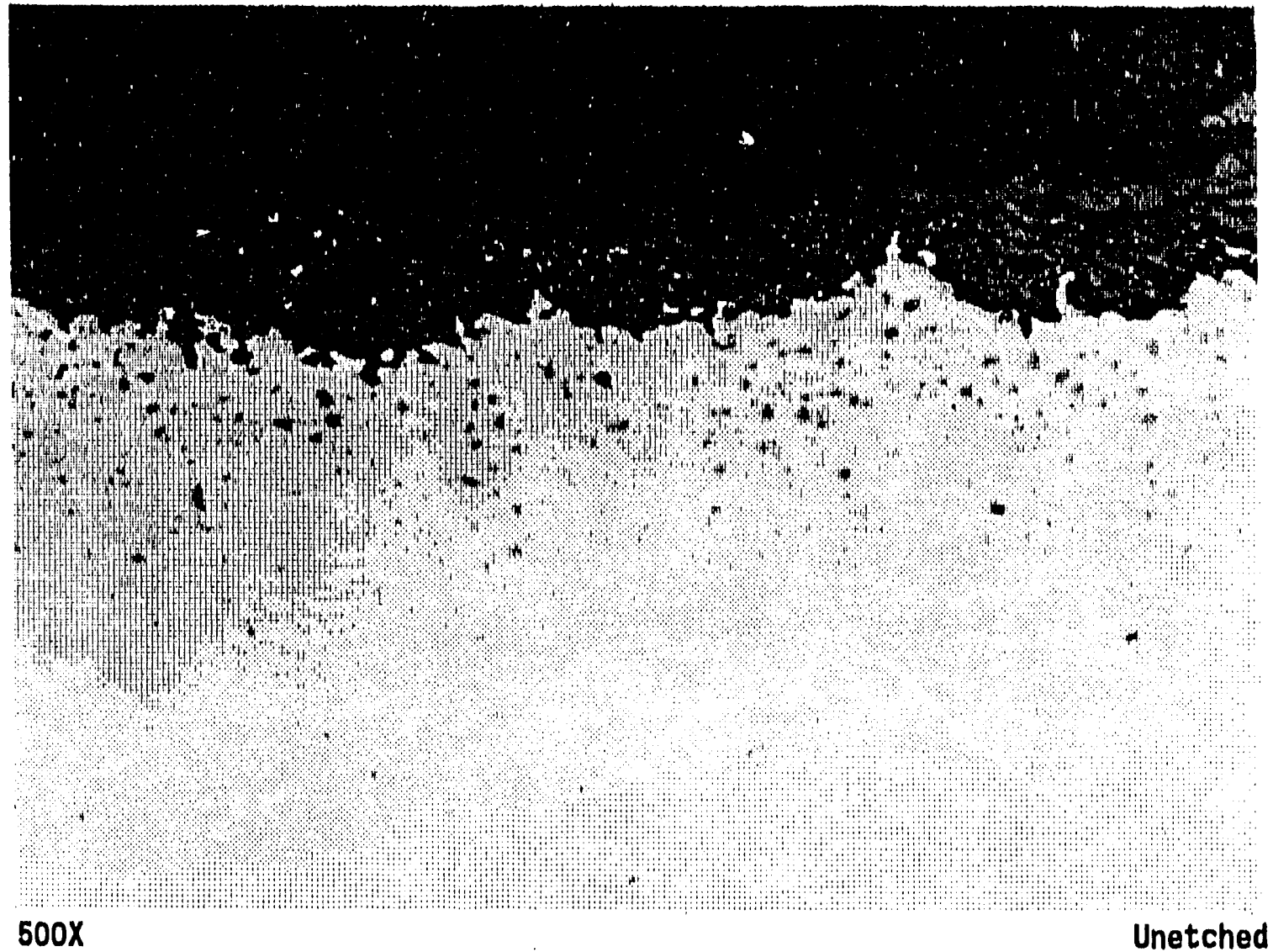

Figure 4.39 Corroded Surface of $310 \mathrm{Nb}$ Specimen After Exposure in PulverizedCoal-Fired Boiler for 16,000 Hours. (Note general sulfidation/ oxidation below layer of scale.) 

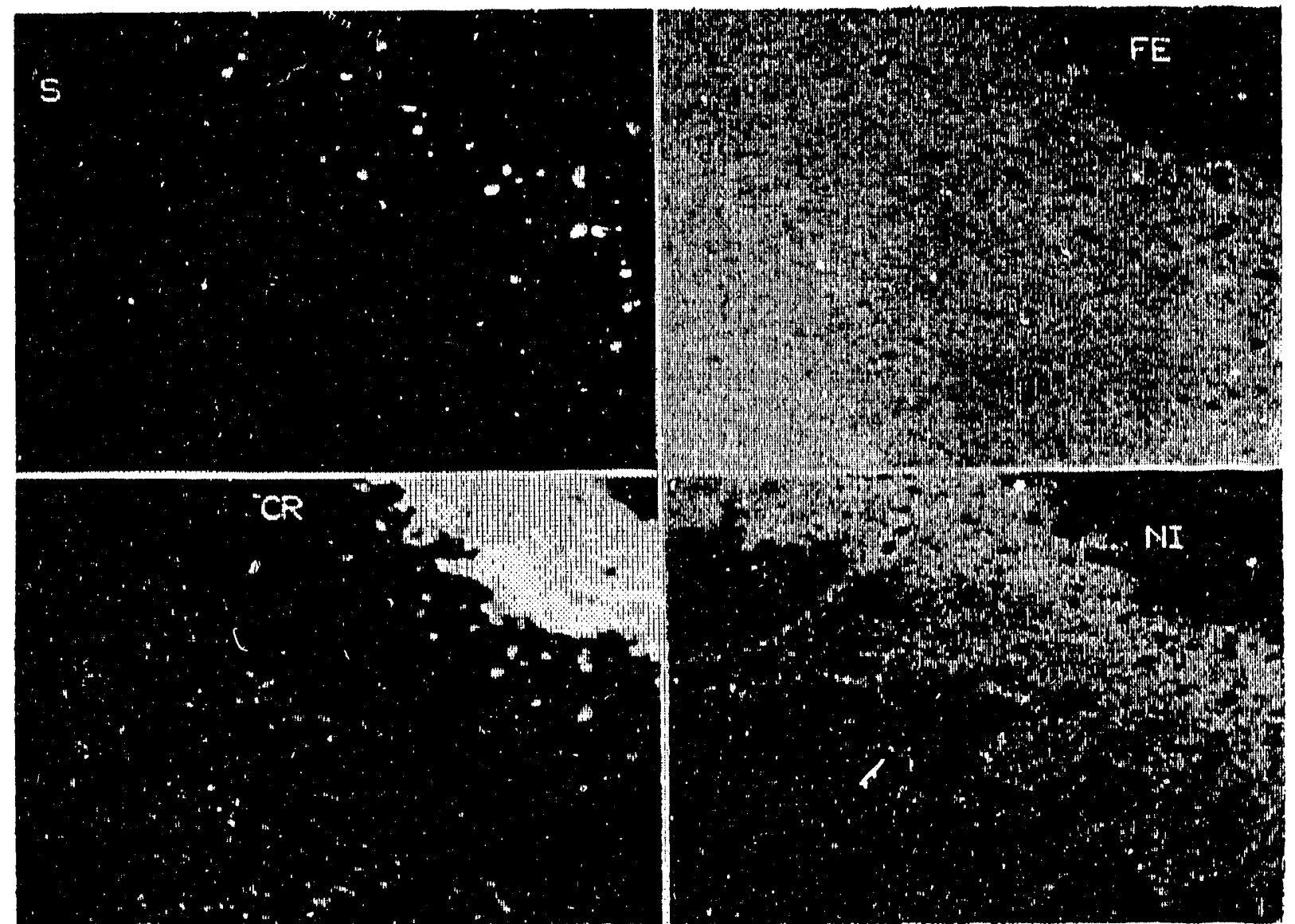

$600 x$

Relative Concentration of Element

Figure 4.40 X-Ray Map of Corroded Surface of $310 \mathrm{Nb}$ Specimen After Exposure for 16,000 Hours in Pulverized-Coal-Fired Boller 


\subsection{ANALYSIS OF CLAD COUPONS}

Comparing the corrosion morphologies described above, several trends become evident. Alloys with little intrinsic resistance to AIT attack, or alloys exposed to highly aggressive environments, do not show subsurface chromium depletion. Alloys that were resistant to attack and were exposed to moderately aggressive environments suffered subsurface chromium depletion below the attacked areas. Alloy $310 \mathrm{Nb}$, which was exposed in an operating utility boiler, also exhibited subsurface chromium depletion, indicating that this is not the result of the experiment. Intergranular attack al so occurs to varying degrees along with generalized subsurface attack on the more highly resistant alloys. A fully developed example of this attack can be seen on Alloy $310 \mathrm{Nb}$, which has been exposed for 16,000 hours.

The unexpectedly high rate of corrosion in the modified Alloy 316 specimen clad with Alloy 690 may have been the result of the coalescence of chromium compounds at the grain boundaries, leading to intergranular attack. Figure 4.41 shows patches of grains falling from the specimen surface. What appears to be chromium carbides are "decorating" the grain boundaries. In addition to intergranular attack, oxidation/sulfidation and AIT attack are occurring on this specimen. Figure 4.42 shows a patch of this form of corrosion. A band of sulfidation and oxidation is preceding the AIT attack. Intergranular attack, generalized oxidation and sulfidation, and AIT attack may interact synergistically. If localized intergranular attack creates pitting on the surface of the specimen, a corrosion cell may form between the AIT in the pit and the AIT elsewhere, greatly enhancing corrosion rates in the pit.

The specimen of Alloy 800 clad with Alloy 72 (Figure 4.43) suffered a higher-than-expected rate of attack because of the presence of the Alloy $800 \mathrm{H}$ base material, wich was not completely machined from the surface. The fusion line between the oase metal on the top and the cladding on the bottom is clearly visible in the photograph. 


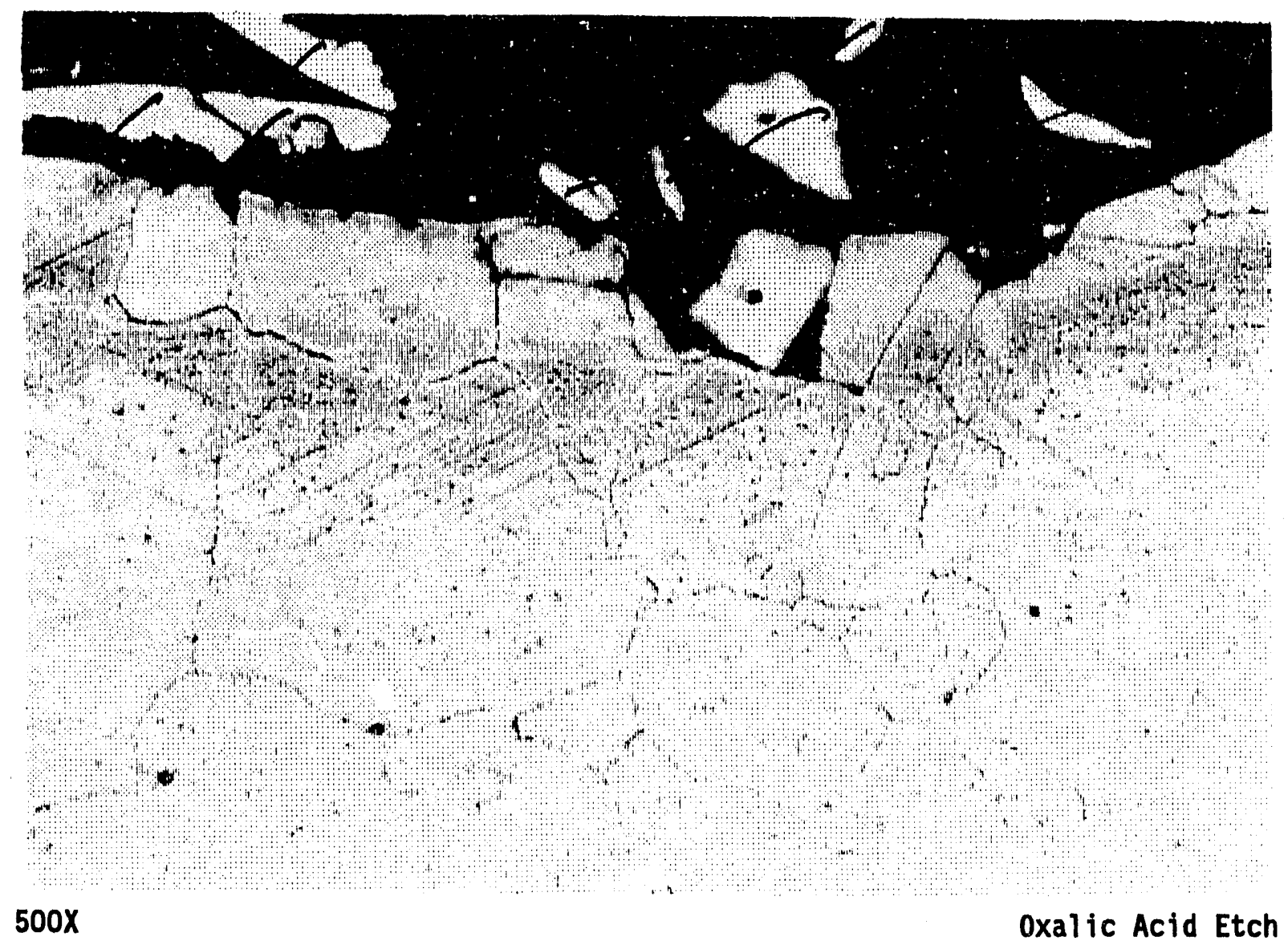

Figure 4.41 Intergranular Attack on Corroded Surface of 690 Cladding/Type 316 Base Metal Coated With 10 wt\% Alkali Sulfates After Exposure for 800 Hours at $700^{\circ} \mathrm{C}$ to 0.25 vol\% $\mathrm{SO}_{2}$ 


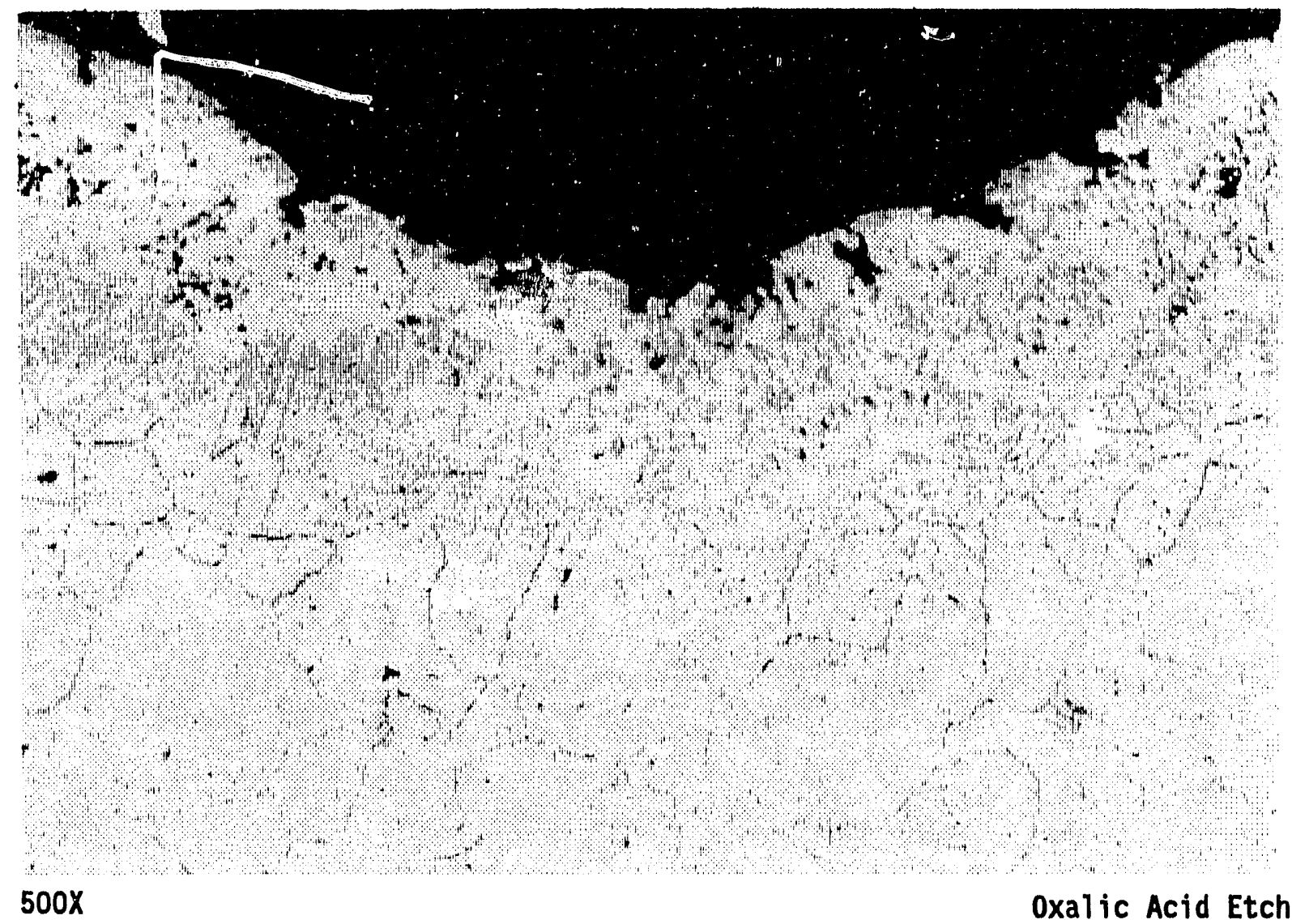

Figure 4.42 Chromium Depletion and General Sulfidation/0xidation Below Layer of Scale on Corroded Surface of 690 Cladding/Type 316 Base Metal Coated With 10 wt\% Alkali Sulfates After Exposure for 800 Hours at $700^{\circ} \mathrm{C}$ to $0.25 \mathrm{vol}^{\circ} \mathrm{SO}_{2}$ 

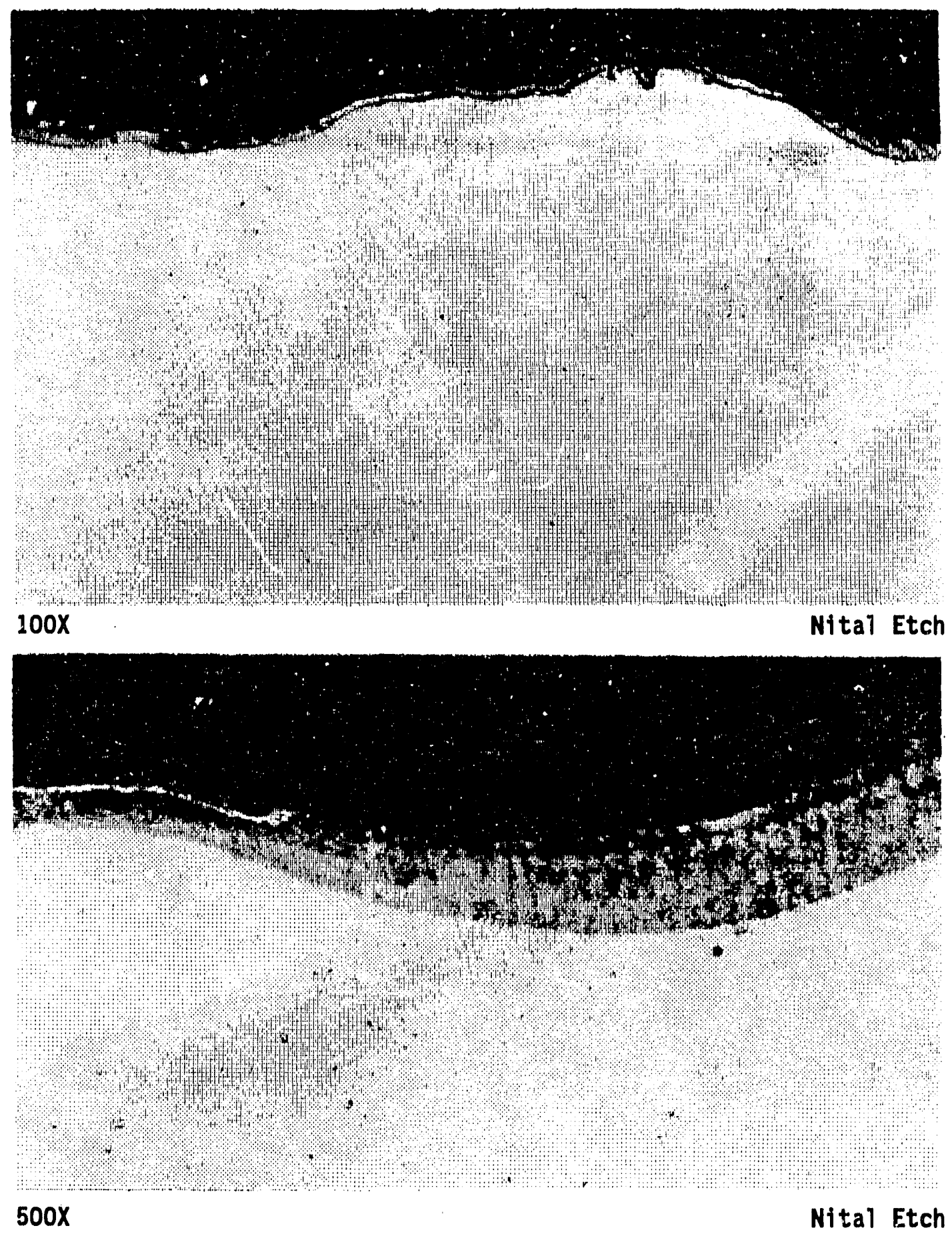

Figure 4.43 Corroded Surface of 72 Weld Wire Deposited on Incoloy 800 Base Metal Coated With 10 wt\% Alkali Sulfates After Exposure for 800 Hours at $700^{\circ} \mathrm{C}$ to 0.25 vol\% $\mathrm{SO}_{2}$. (Note thin layer of 800 on top of welded over?ay.) 


\section{Section 5 \\ DETERMINATION OF OBSERVED WASTAGE MECHANISMS}

Since the 1970s, the prevailing theory regarding AIT attack has been the molten fluxing model. Articles by Stringer []], Rapp [7], Hendry and Lees [్] , and others cover this model in detail, so only a brief review will be given here. Above approximately 550 to $600^{\circ} \mathrm{C}, \mathrm{SO}_{3}$ reacts with $\mathrm{Fe}_{2} \mathrm{O}_{3}$ and $\mathrm{Na}_{2}\left(\mathrm{SO}_{4}\right)$ or $\mathrm{K}_{2}\left(\mathrm{SO}_{4}\right)$ to form molten AIT. This molten species is believed to promote metal wastage by fluxing the protective oxide scale from the metal surface. Degradation of the oxide film most likely occurs by an electrochemical mechanism, which may have broadly separated anodic and cathodic regions. Above approximately $725^{\circ} \mathrm{C}$, ferric sulfate in the melt becomes unstable at nominal $\mathrm{SO}_{3}$ pressures, and the AIT decomposes back into iron oxide and alkali sulfates.

\subsection{POSSIBLE MECHANISMS OF MOLTEN AIT ATTACK ON IRON- OR NICKEL-BASED ALLOYS}

Corrosion morphologies on iron- or nickel-based specimens attacked by AITs can be divided into two general categories: general attack and pitting. Since hot corrosion is an electrochemical phenomenon, one would expect to find many similarities ietween what is occurring in molten trisulfate films and the more familiar room-temperature aqueous corrosion. General attack occurs in aqueous corrosion when the metal being corroded develops little or no passivity. Similarly, general attack by molten AIT occurred on the lower-chromium stainiess steels exposed to high concentrations of sulfate or $\mathrm{SO}_{2}$. No passive layer of chromia could form under these harsh conditions; consequently, generalized attack resulted. In many cases, although the entire specimen was attacked, there were irregularities. Shallow, scalloped pits and depressions were common features on the attacked surface. These pits and depressions might have been caused by local electrochemical cells set up on the surface. The cells, in turn, may have been caused by local differences in $\mathrm{SO}_{2}$ concentration or variations in the underlying metal.

In less-aggressive environments, molten trisulfate attack on moderateto high-chromium alloys resulted in localized pitting rather than generalized attack over the entire surface. Pitting and crevice corrosion occur in alloys as a result of local breakdowns of passivity. Once local passivity is destroyed, an electrochemical corrosion cell may form, promoting further attack within the pit while cathodically protecting the surrounding area.

One mechanism for pitting attack in molten trisulfate could be as follows: At a given temperature, a minimum level of $\mathrm{SO}_{2}$ is needed in the flue gas to convert the alkali sulfates and iron oxide in the ash into molten AITs. When the ash layer is laid down, either in the laboratory or from burning coal in a boiler, the ash layer will not be completely uniform. Gases diffuse to the metal surface more readily in areas where the ash layer is thinner than usual, or regions near the edge of the ash layer. The different levels of $\mathrm{SO}_{2}$ concentration under the ash layer cause molten AITs to form at different

rates. Different levels of $\mathrm{SO}_{2}$ might a? so lead to different aggressiveness of the molten trisulfates. Once the molten trisulfate degrades the passive layer locally, an electrochemical corrosion cell can form (with the incompletely protected metal in the pit forming an anodic region), cathodically protecting 
the area surrounding the pit. Active areas could also protect the rest of the inetal surface by acting as a sink for reactants. The reaction products are oxides and sulfides of iron, nickel, and chromium; as the reaction proceeds, oxygen and sulfur are depleted from the melt surrounding the pit. This oxygen and sulfur depletion creates a diffusion gradient toward the already-active areas and away from the passive areas, helping them remain passive.

\subsection{SUBSURFACE EFFECTS DURING MOLTEN AIT_ATTACK}

AIT corrosion on resistant alows often accompanied by subsurface attack on the alloy, taking the form nfitergranular attack, subsurface penetration of sulfides and oxides, or selective depletion of elements from the alloy. Intergranular attack and subsurface penetration can be attributed to an oxidation/sulfidation mechanism, while selective depletion can be understood if a mass balance for elements consumed in sulfidation and oxidation is considered. Possible mechanisms for these attack modes have been discussed in the literature [9] .

Both intergranular attack and the formation of subsurface oxides and sulfides can be explained by the migration of sulfur and oxygen through a thin passive layer. The sulfur concentration necessary to sustain a molten sulfate layer could be expected to provide high enough activity to drive sulfur through a thin film of chromia. Once in the metal, the sulfur combines with chromium and other sulfide formers. Depending upon the alloys microstructure, in particular whether the alloy is in a sensitized condition, sulfidation may occur--either as uniform sulfide penetration or as internal sulfidation along the grain boundaries. Oxygen may also diffuse through the passive layer, producing combined oxidation/sulfidation attack.

The depletion of elements from a thin band riext to the surface can be understood by considering that chromium-rich features such as a passive layer on the surface and subsurface sulfides and oxides must get chromium from somewhere-.. and that "somewhere" is the rest of the specimen. Because of the limited diffurivity of chromium, only a small volume of metal is available from which to draw the chromium, leading to a thin, depleted band of material underneath the chromium-rich passive layer.

\subsection{MECHANISMS OF ATTACK ON INTERMETALLIC ALUMINIDES}

Much of what has been discussed about iron- and nickel-based alloys also applies to intermetallic aluminides. Like stainless steels, the mechanism of attack for these alloys appears to be electrochemical in nature. $X$-ray mapping of corroded specimens indicates that attack occurs by the fluxing off of a passive film composed primarily of alumina. Several specimens showed evidence of intergranular attack; however, there was no indication of subsurface penetration or selective depletion of elements.

The aluminides appeared to have also suffered gas-phase attack, in addition to AIT attack. Several nickel-containing specimens suffered catastrophic corrosion, apparently the result of the gas-phase attack. One corrosion mechanism appeared to be gas-phase attack into preexisting cracks and rolling laps, causing the specimen to swell and crack further. In several cases this swelling and cracking completely destroyed nickel aluminide 
specimens within 800 hours. Iron aluminides, based on $\mathrm{Fe}_{3} \mathrm{Al}$, showed general pitting attack, which was somewhat greater for the $2 \% \mathrm{Cr}$ alloy than for the alloy containing $5 \% \mathrm{Cr}$.

\subsection{HOH MATERIAL AND ENVIRONMENTAL VARIABLES AFFECT CORROSION RESISTANCE}

From the background presented in the preceding two sections, we can gauge the effects ihat various alloying elements or changes to the environment have on the corrosion resistance of an alloy. For an alloy to be successful in a boiler environment, it must be resistant to both AIT attack and various forms of sulfidation attack. As the graph in Figure 4.1 showed, chromium is the element primarily responsible for resistance against AIT attack. This resistance is widely believed to be due to a passive layer of chromia formed on the metal surface. Other elements that appear to improve resistance to AIT attack include aluminum and silicon, both of which form stable oxides and may improve stability of the passive layer. Aluminum and silicon have also been found to improve resistance to sulfidation.

Higher concentrations of either the alkali sulfates in the ash or the $\mathrm{SO}_{2}$ in the flue gas increased the corrosion rate. This increase was most likely the result of greater activity of the reactants in the molten trisulfate layer. Higher concentrations of $\mathrm{SO}_{2}$ in the flue gas would be expected to increase sulfur diffusion into the metal, tying up chromium and accelerating the corrosion rate. The delayed effects of sulfidation may explain why some alloys suffered breakaway corrosion during longer exposure times. Degradation and attack may occur in high-chromium alloys by sulfidation tying up chromium, and AIT can attack the chromium-depleted layer. This mechanism would require an incubation period for the depletion of chromium from the alloy. The incubation period is determined by the rate that sulfur diffuses into the metal and combines with chromium. Sulfidation is well known to have long incubation periods, possibly lasting for thousands of hours. However, once chromium is depleted, breakaway corrosion may start. The possibility that this incubation period exists would suggest that short-term laboratory tests may be overly optimistic. Alloys that perform satisfactorily in the laboratory do not always hold up as well under service conditions. 


\section{Section 6 \\ CONCLUSIONS AND RECOMMENDATIONS}

The general nature of AIT attack is well understood, and there is a consensus on the basic mechanisms of attack. The attack rates and morphologies observed on specimens exposed to conditions simulating the superheater section of a PCfired boiler were similar to those found by previous investigators. The attack appeared to be caused by a molten trisulfate layer forming on the metal surface. Examination of the ash layer after exposure revealed a fused band next to the metal surface, which appeared to have been molten during exposure.

In addition to the molten AIT attack, a number of specimens show evidence of subsurface sulfidation and oxidation in the form of either intergranular attack or uniform penetration. Sulfidation and oxidation occurred primarily on the more-resistant alloys exposed for 800 hours, the longest exposure time. Examination of a Type $310 \mathrm{Nb}$ probe specimen taken from an operating PC-fired boiler after 2 years of exposure showed similar forms of sulfur penetration and intergranular attack, adding support that this is a operating attack mode and not the result of laboratory testing. Several specimens exhibiting sulfidation suffered breakaway corrosion at longer exposure times, indicating that sulfidation and AIT attack may be synergistic.

In the alloys evaluated, resistance to attack appeared to be determined primarily by the chromium content of the alloy. Up to 30-percent chromium appears to improve resistance to attack in these alloys. Above 30 percent, resistance does not seem to improve. Additions of silicon and aluminum al so appear to be beneficial in resisting AIT attack. Molybdenum, on the other hand, may be detrimental to resistance.

While there is no complete solution to AIT attack, incremental improvements are being made. Alloy's and claddings with a chromium content above 30 percent appear to have substantial resistance to attack, validating previous research. A new alloy, CR35A, had excellent resistance to attack. The claddings tested generally performed as well as the base alloy. Two cases of breakaway corrosion occurred on clad specimens; however, these were anomalies. Although further testing is needed to determine long-term suitability, both CR35A and the claddings tested appear quite promising.

Alloy RAB5H may provide better resistance than alloys with similar chromium contents, such as Alloy 347. RA85H suffered less wastage than alloys containing similar chromium levels; however, intergranular attack was found on several of the RA85H specimens, possibly leading to breakaway corrosion. Although RAB5H holds promise, long-term exposures are needed to determine whether breakaway corrosion will occur.

The aluminide alloys tested showed wide variance in their resistance to both molten trisulfate attack and gas-phase attack. Neither the nickel aluminide nor the iron aluminide containing 2-percent chromium held up as well as the more conventional stainless steels. The iron aluminide containing 5-percent chromium performed as well as Alloy 347. Given the low chromium content of the iron aluminides and their newness, further development of this alloy system may lead to alloys with improved molten trisulfate attack resistance. 


\section{Section 7}

\section{REFERENCES}

1. I. M. Rehn, "Corrosion Problems in Coal-Fired Boller Superheater and Reheater Tubes," EPRI CS-1653, Project 644-1, Final Report, November 1980.

2. I. M. Rehn, "Laboratory Fireside Corrosion Evaluation of Improved Super. heater Tube Alloys and Coatings," EPRI CS-3134, Project 644-1, Final Report, Jure 1983.

3. I. M. Rehn, "Fireside Corrosion of Superheaier Alloys for Advanced-Cycle Steam Plants," EPRI CS-5195, Project 1403-11, Final Report, May 1987.

4. S. Kthara, W. Wolowodiuk, K. Nakagawa, "Laboratory Coal Ash Corrosion Tests," EPRI GS-6449, Project 1403-19, Final Report, July 1989.

5. J. Blough and W. T. Bakker, "Measurement of Superheater Corrosion by Molten Alkali Sulfates," Heat-Resistant Materials, Proceedings of the First International Conference, Fontana, Wisconsin, ASM International, Materials Park, Ohio, September 1991, pp. 567-576.

6. J. Stringer, "High Temperature Corrosion Problems in the Electric Power Industry and Their Solution," High Temperature Corrosion, International Corrosion Conference Series-Volume 6, National Association of Corrosion Engineers, Houston, Texas, 1983.

7. R. A. Rapp, "Chemistry and Electrochemistry of the Hot Corrosion of Metals," Corrosion-NACE, Volume 42, Number 10, October 1986.

8. A. Hendry and D. J. Lees, "Corrosion of Austenitic Steels in Molten Sulphate Deposits," Corrosion Science, Volume 20, Permagon Press Ltd, England, 1980.

9. G. Y. Lai, High Temperature Corrosion of Engineering Alloys, ASM International, Materials Park, Ohio, 1990. 
APPENDIX A 
Recoated Between Exposures:

$\mathrm{Fe}_{3} \mathrm{Al}-8$

$\mathrm{Fe}_{3} \mathrm{Al}-5 \mathrm{Cr}-27$
Steam Cleaned and Recoated Between Exposures:

$\mathrm{Fe}_{3} \mathrm{Al}-9$

$\mathrm{Fe}_{3} \mathrm{~A} 1-5 \mathrm{Cr}-28$

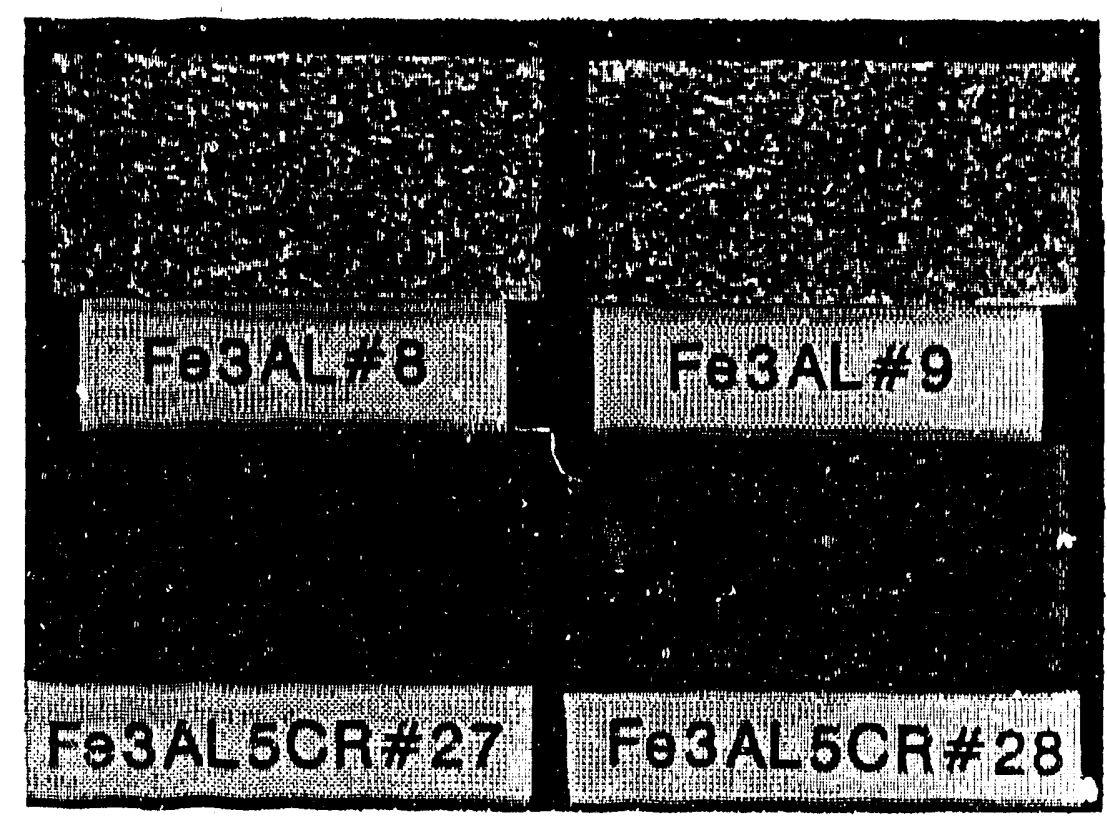

Gas Content:

Temperature:

1.0 vol\% SO

Exposure Time:

$700^{\circ} \mathrm{C}$

Suifate Content:

800 hours

$10 \mathrm{wt} \%$ 
Recoated Between Exposures:

$\begin{array}{ll}556-27 & 17-14 \text { CUMo-14 } \\ 671 / 316-14 & 690 / 316-27\end{array}$

Steam Cleaned and Recoated Between Exposures:

$\begin{array}{ll}72 / 80 O H-29 & 690-9 \\ 72 / \text { LSS }-29 & 690 / 316-28 \\ 347-22 & 316-23\end{array}$

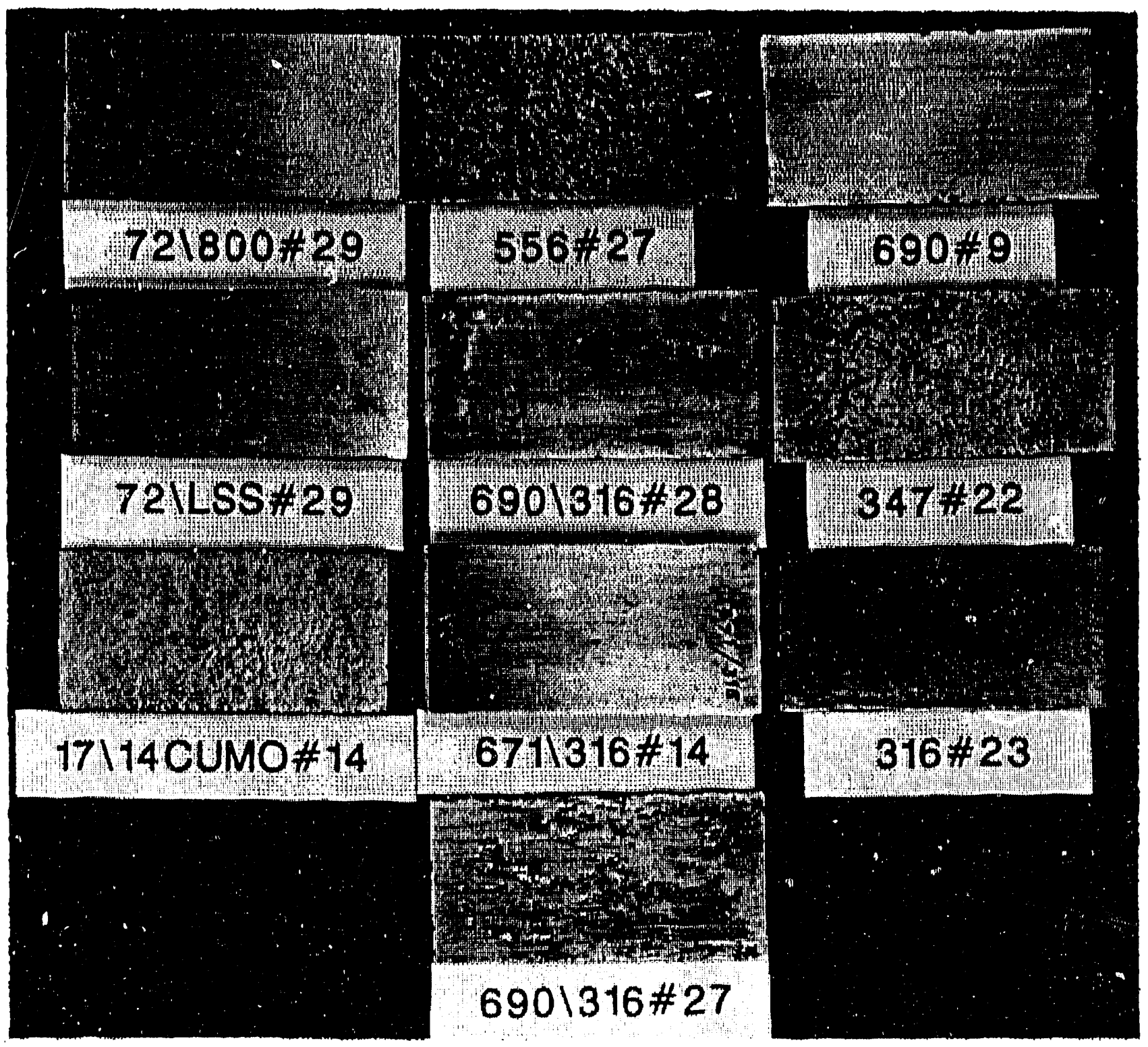

Gas Content:

Temperature:

Exposure Time:

Sulfate Content:
$1.0 \mathrm{V0} 1 \% \mathrm{SO}_{2}$

$700^{\circ} \mathrm{C}$

800 hours

10 wt\% 
Recoated Between Exposures:

$\begin{array}{ll}72 / 800 \mathrm{H}-28 & 671-8 \\ \text { RA85H-21 } & 347-21 \\ 800 \mathrm{H}-27 & \text { HR3C }-27\end{array}$

Steam Cleaned and Recoated Between Exposures:

$\begin{array}{ll}690 / 800 \mathrm{H}-28 & 671 / 316-15 \\ 556-28 & 17-14 \text { CUMO-15 } \\ \text { CR35A-25 } & \end{array}$

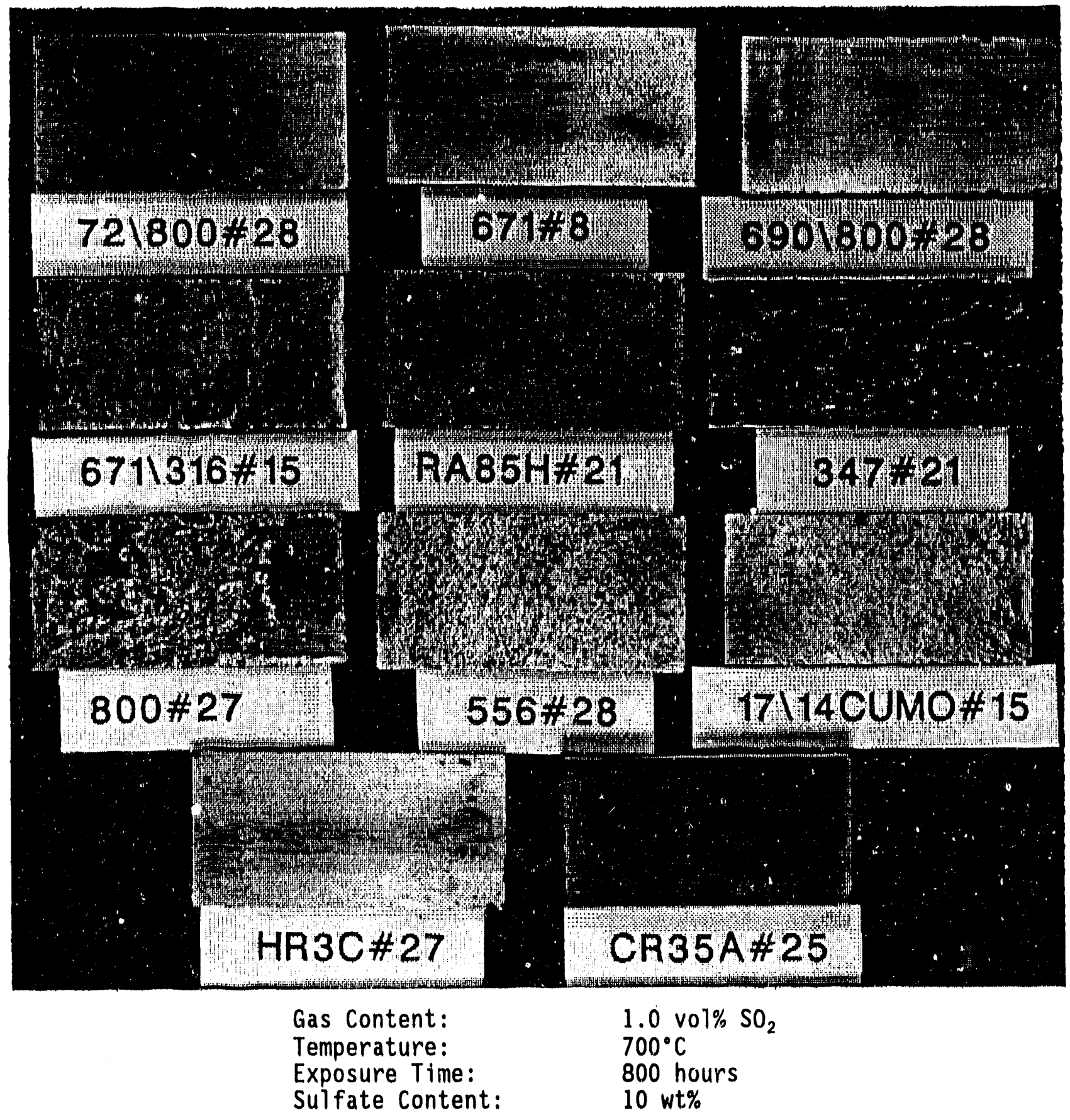


Recoated Between Exposures:

$\mathrm{Fe}_{3} \mathrm{~A} \mathrm{~T}-11$

$\mathrm{Fe}_{3} \mathrm{Al}-5 \mathrm{Cr}-31$
Steam Cleaned and Recoated Between Exposures:

$\mathrm{Fe}_{3} \mathrm{Al}-12$

$\mathrm{Fe}_{3} \mathrm{Al}-5 \mathrm{Cr}-32$

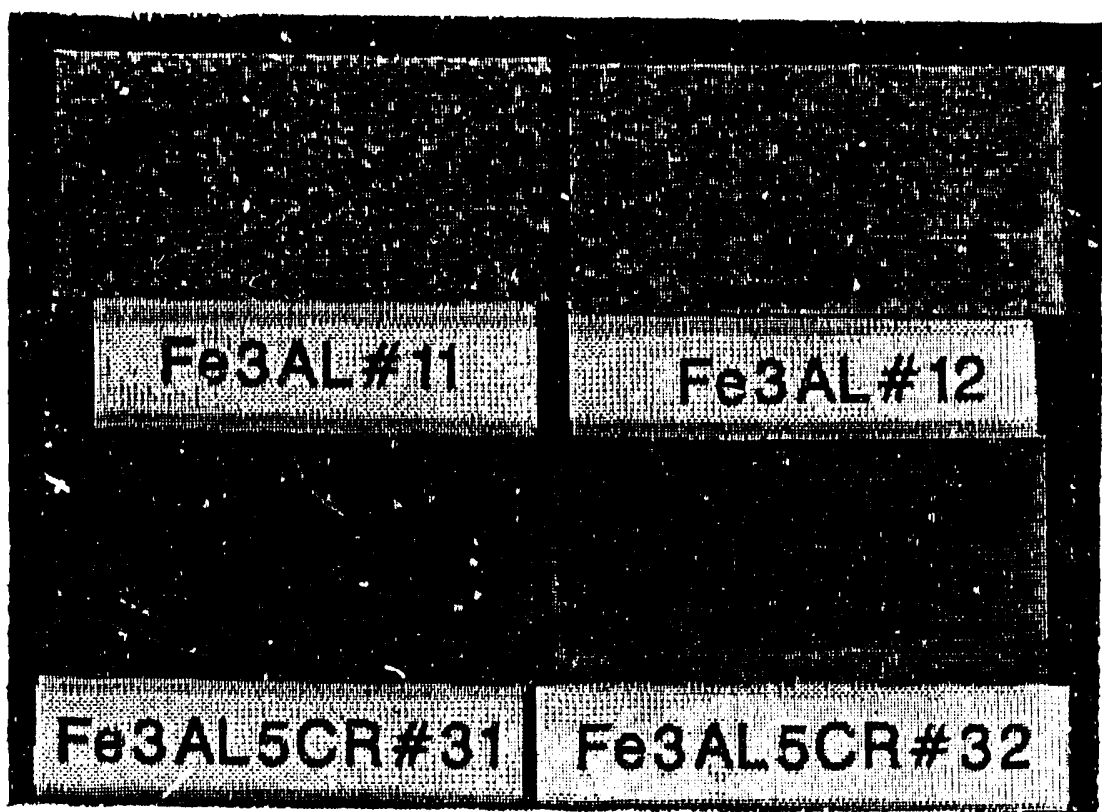

Gas Content:

Temperature:

Exposure Time:

Sulfate Content:
$1.0 \mathrm{Vo}^{2} \% \mathrm{SO}_{2}$

$650^{\circ} \mathrm{C}$

800 hours

$10 \mathrm{wt} \%$ 
Recoated Between Exposures:

690/316-30

690-11

17-14 CuMo-17
Steam Cleaned and Recoated

Between Exposures:

556-31

HR3C-31

$800 \mathrm{H}-31$

$72 / 800 \mathrm{H}-32$

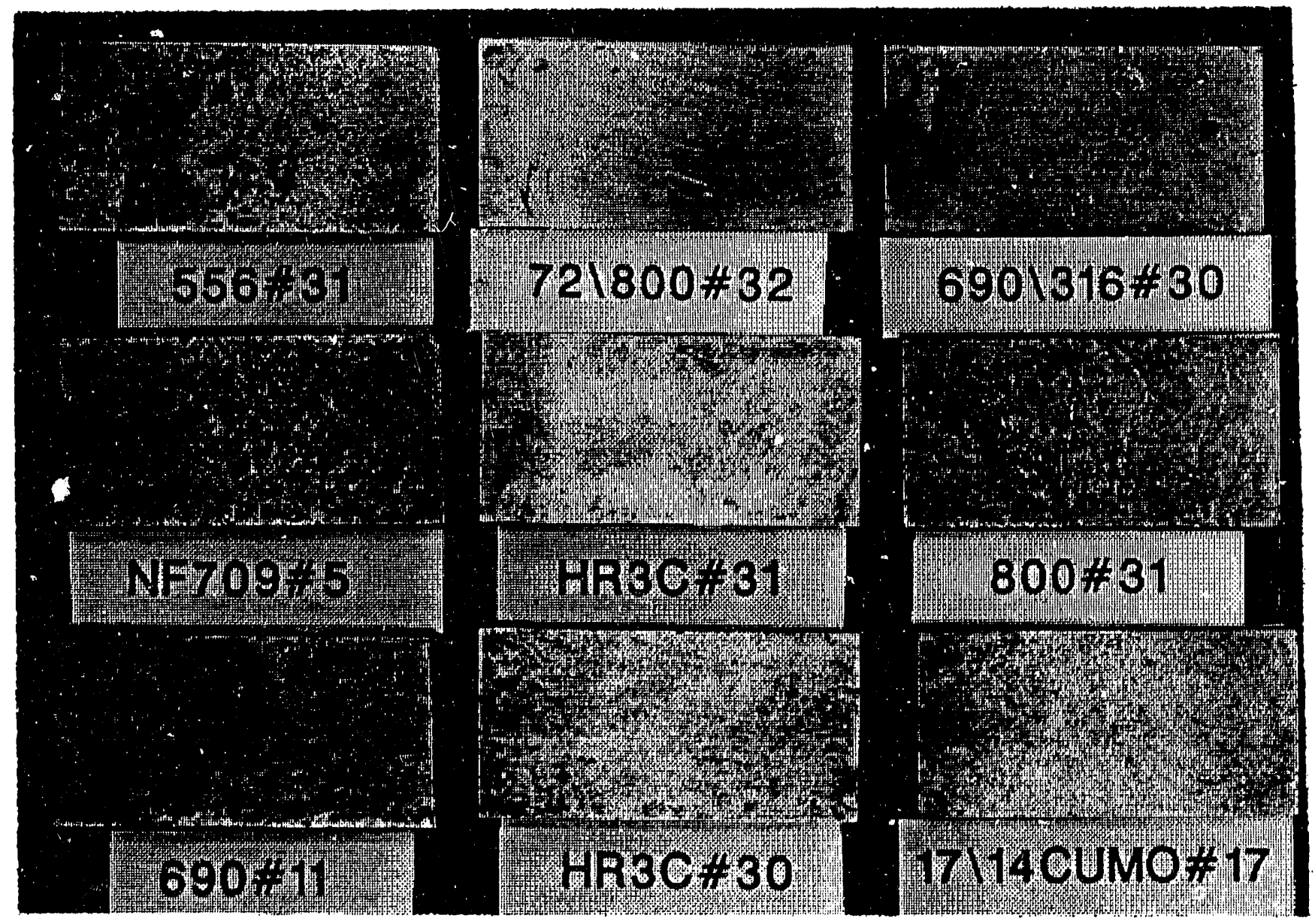

Gas Content:

Temperature:

Exposure Time:

Sulfate Content:
1.0 vol\% $\mathrm{SO}_{2}$

$650^{\circ} \mathrm{C}$

800 hours

$10 \mathrm{wt} \%$ 
Recoated Between Exposures:

$\begin{array}{ll}347-24 & \text { CR35A-27 } \\ 556-30 & 690 / 800 H-30\end{array}$

\author{
CR35A-27
}

Steam Cleaned and Recoated Between Exposures:

NF709-6

72/LSS-32

$690 / 800 \mathrm{H}-31$

17-14 CuMo-18

690-12.
RA85H-25

690/316-31

316-26

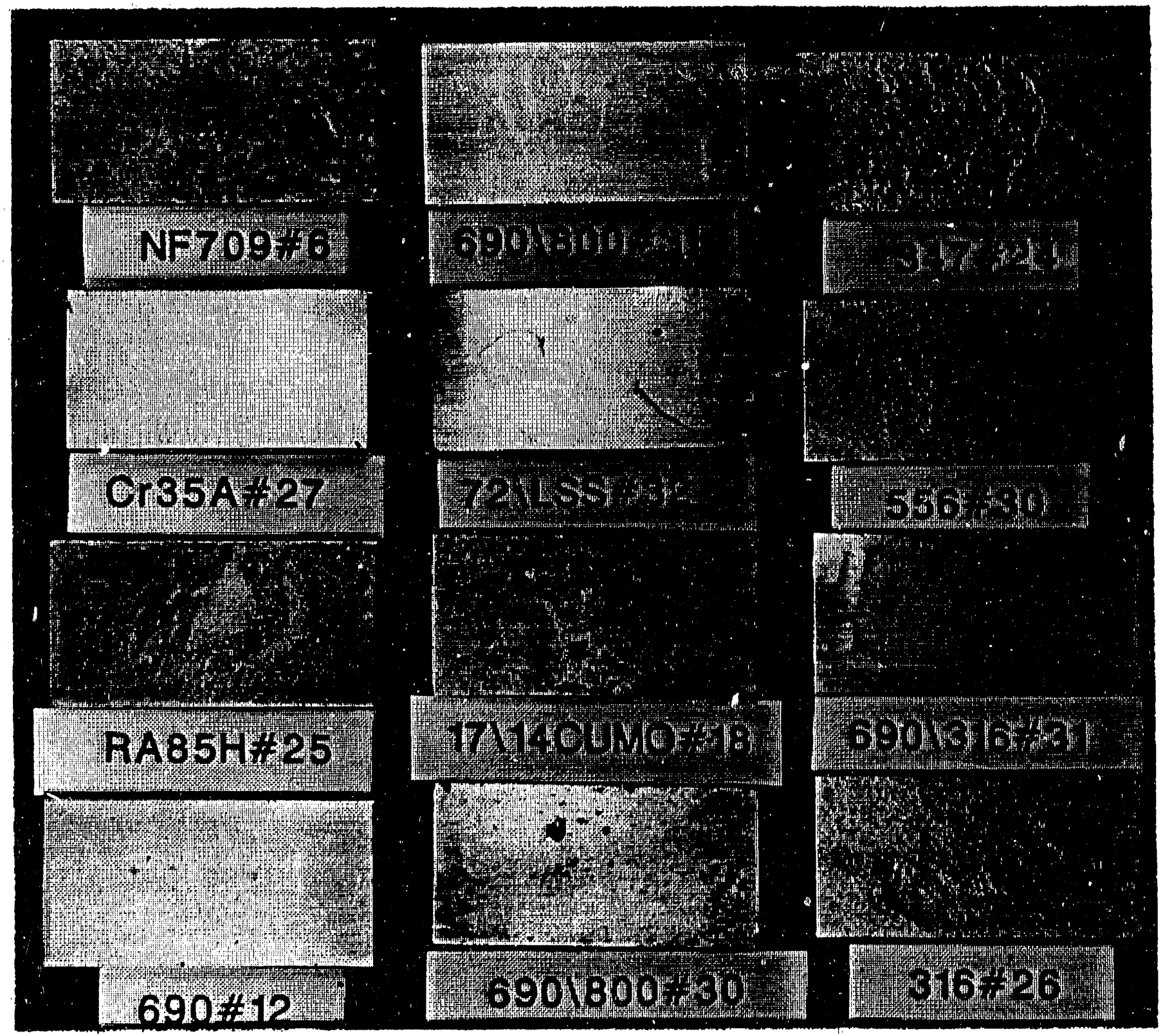

Gas Content:

Temperature:

Exposure Time:

Sulfate Content:
1.0 vol\% $\mathrm{SO}_{2}$

$650^{\circ} \mathrm{C}$

800 hours

$10 \mathrm{wt} \%$ 
Recoated Between Exposures:

$\begin{array}{ll}690-8 & \text { NF709-2 } \\ 316-22 & 671 / 316-14 \\ \text { CR35A-24 } & 72 / \text { LSS }-28\end{array}$

CR35A-24
Steam Cleaned and Recoated Between Exposures:

$\begin{array}{ll}\text { HR3C-28 } & 800 \mathrm{H}-28 \\ 671-9 & \text { NF709-3 } \\ \text { RA85H-22 } & \end{array}$

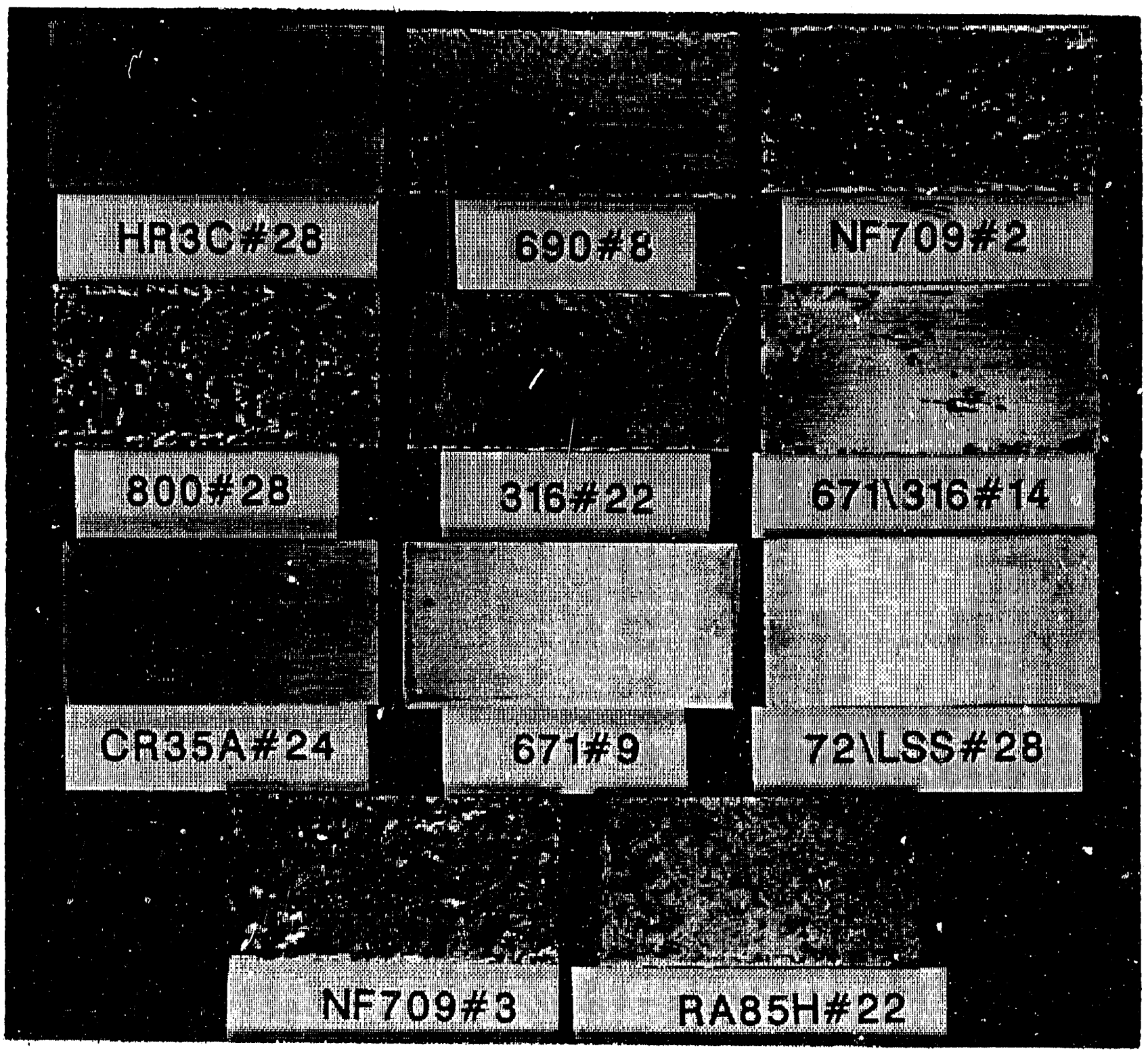

Gas Content:

Temnerature:

Expisure Time:

Sulfate Content:
1.0 val\% $\mathrm{SO}_{2}$

$650^{\circ} \mathrm{C}$

800 hours

$10 \mathrm{wt} \%$ 
Recoated Between Exposures:
RA85H-24
$316-25$
$671-11$
$72 / 80 \mathrm{OH}-31$
72/LSS-31

Steam Cluaned and Recoated Between Exposures:

347-25

CR35A-28
$671-12$

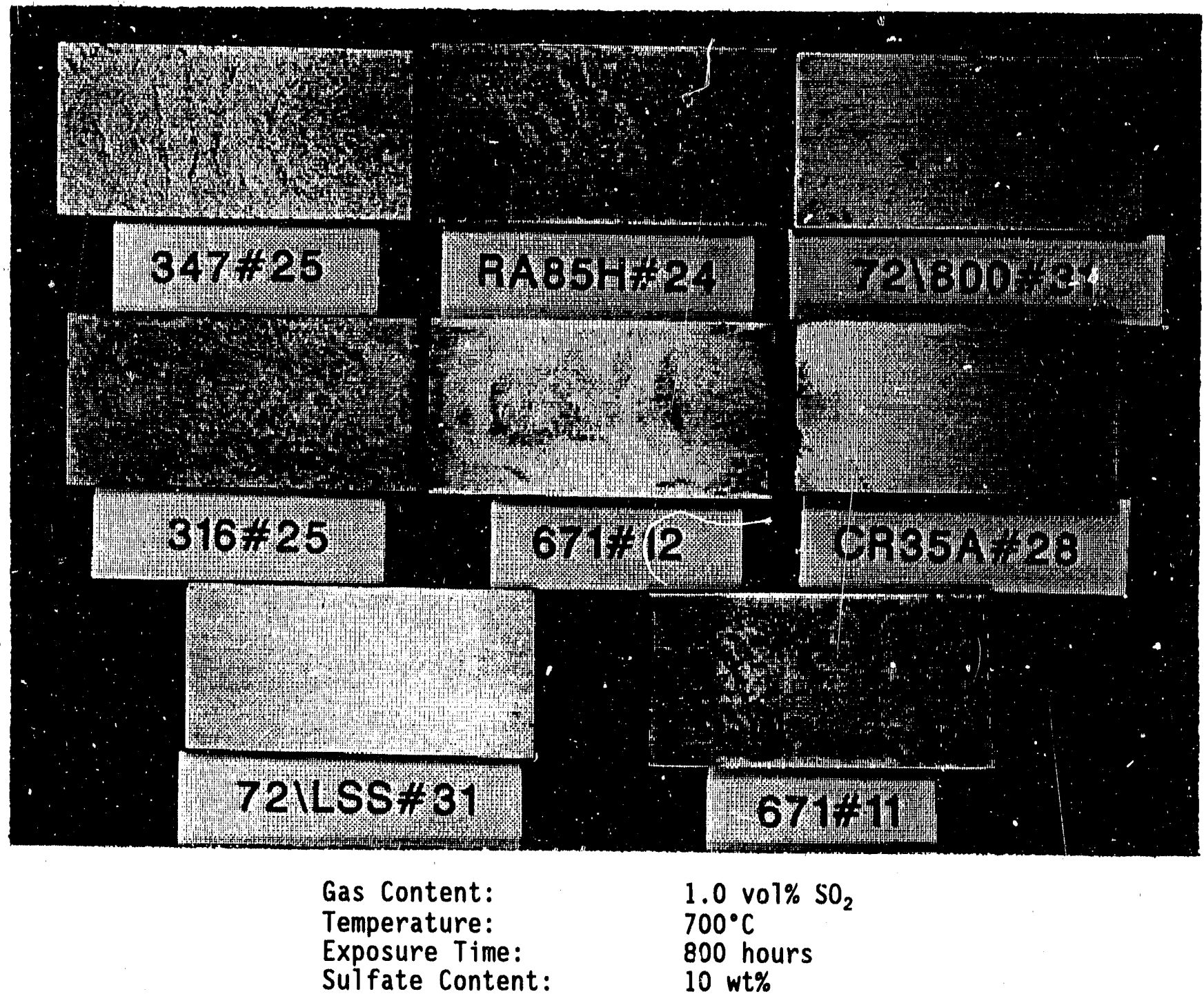



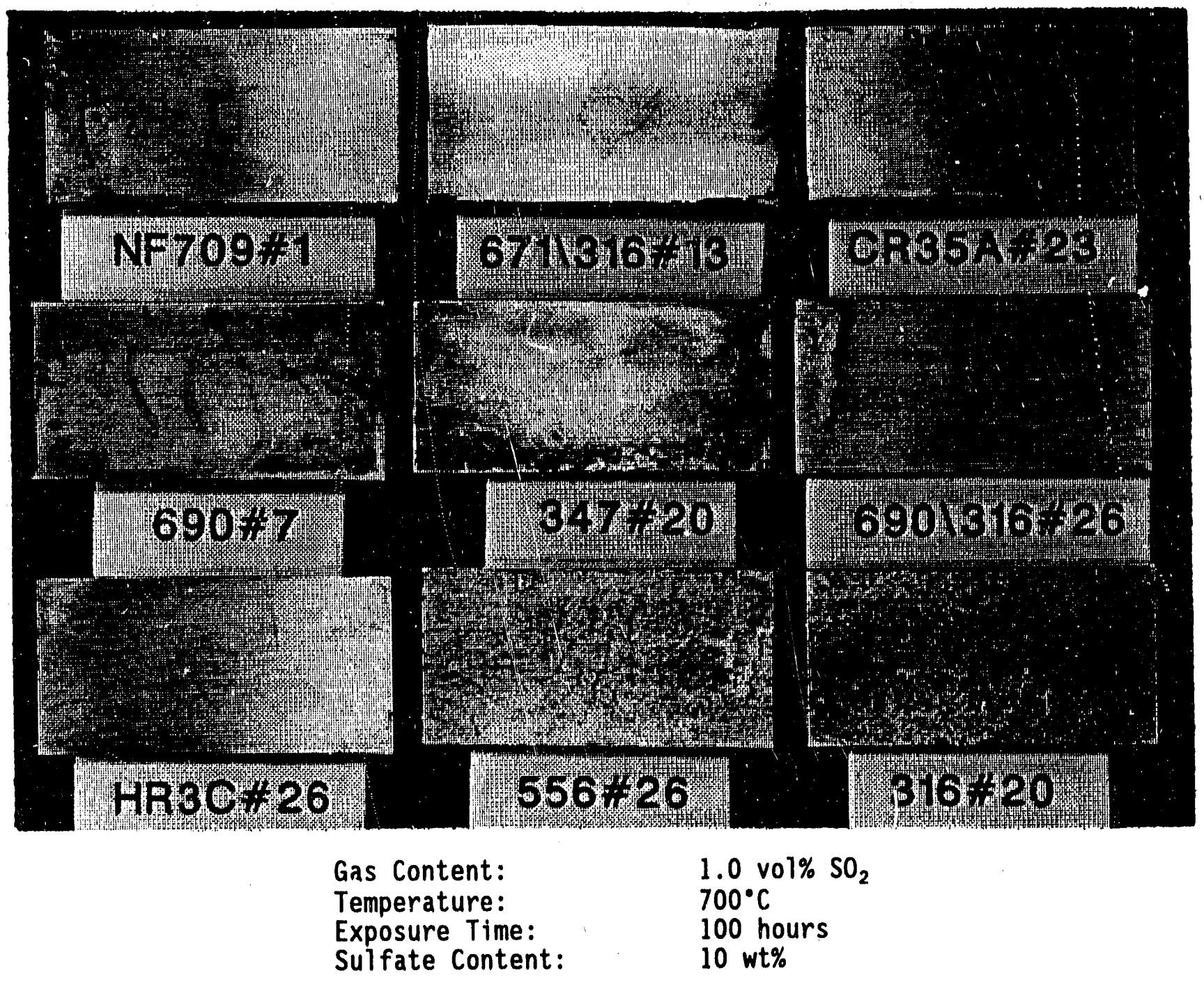


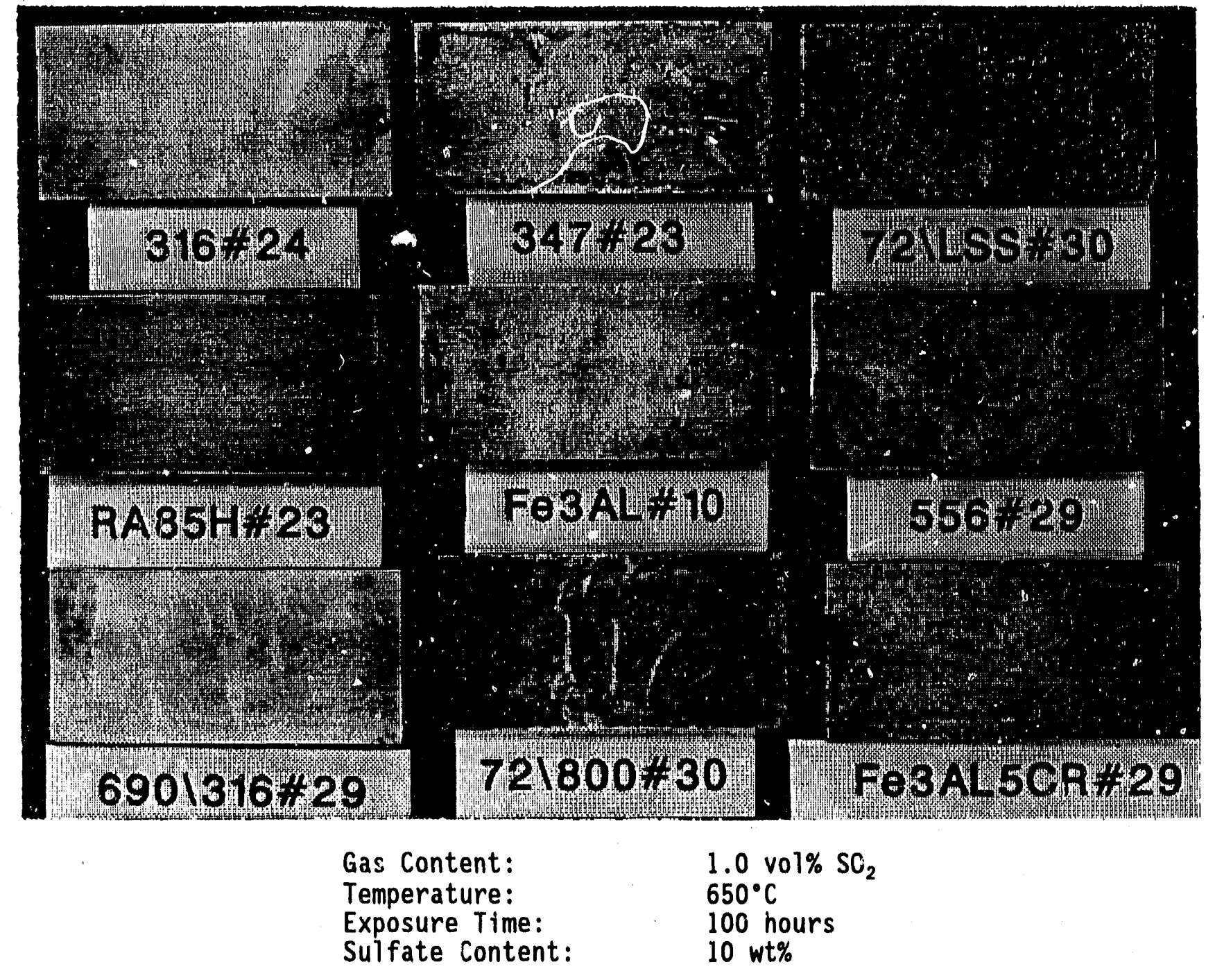




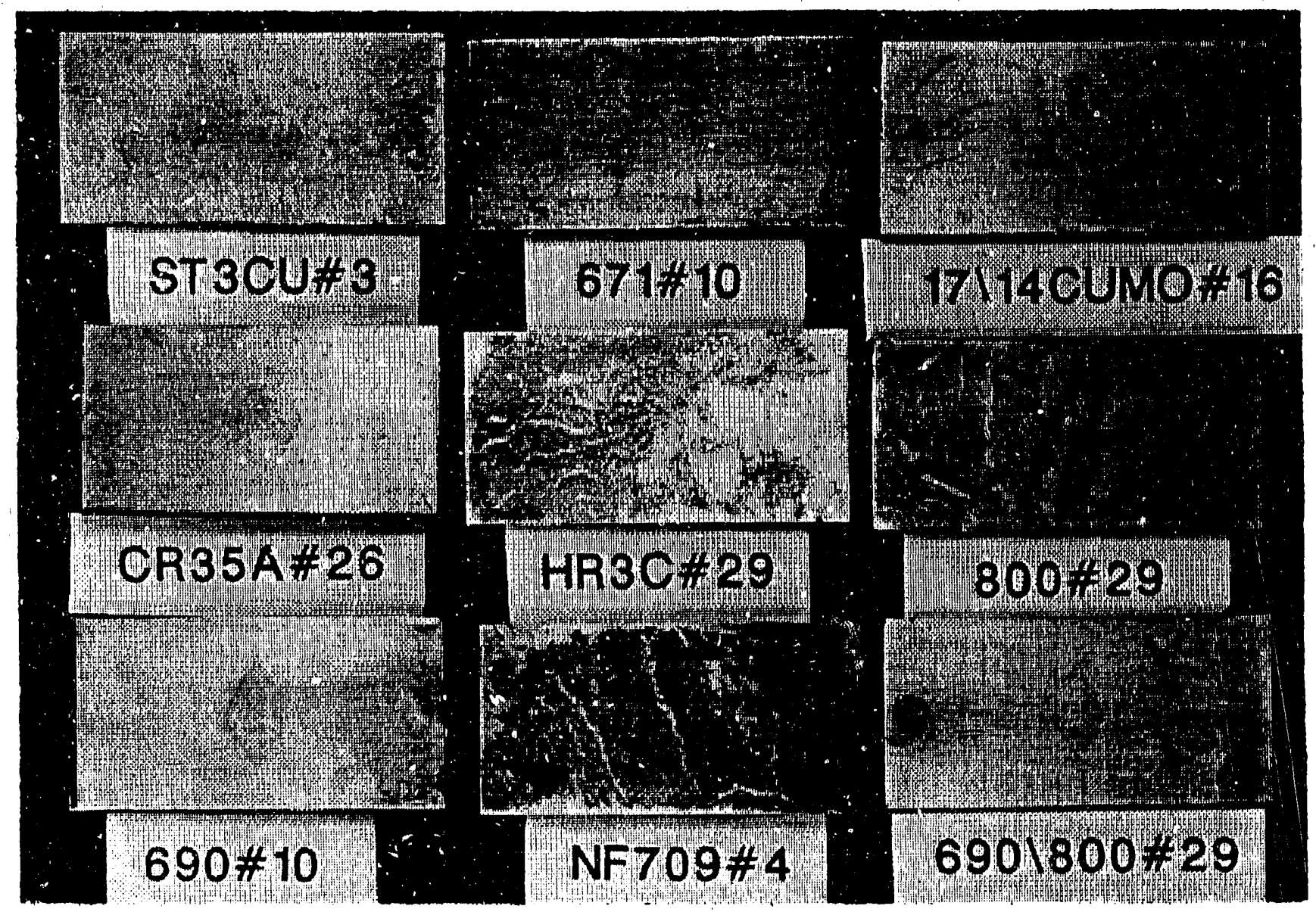

Gas Content:

Temperature:

1.0 vol\% $\mathrm{SO}_{2}$

Exposure Time:

Sulfate Content:

$650^{\circ} \mathrm{C}$

100 hours

10 wt\% 


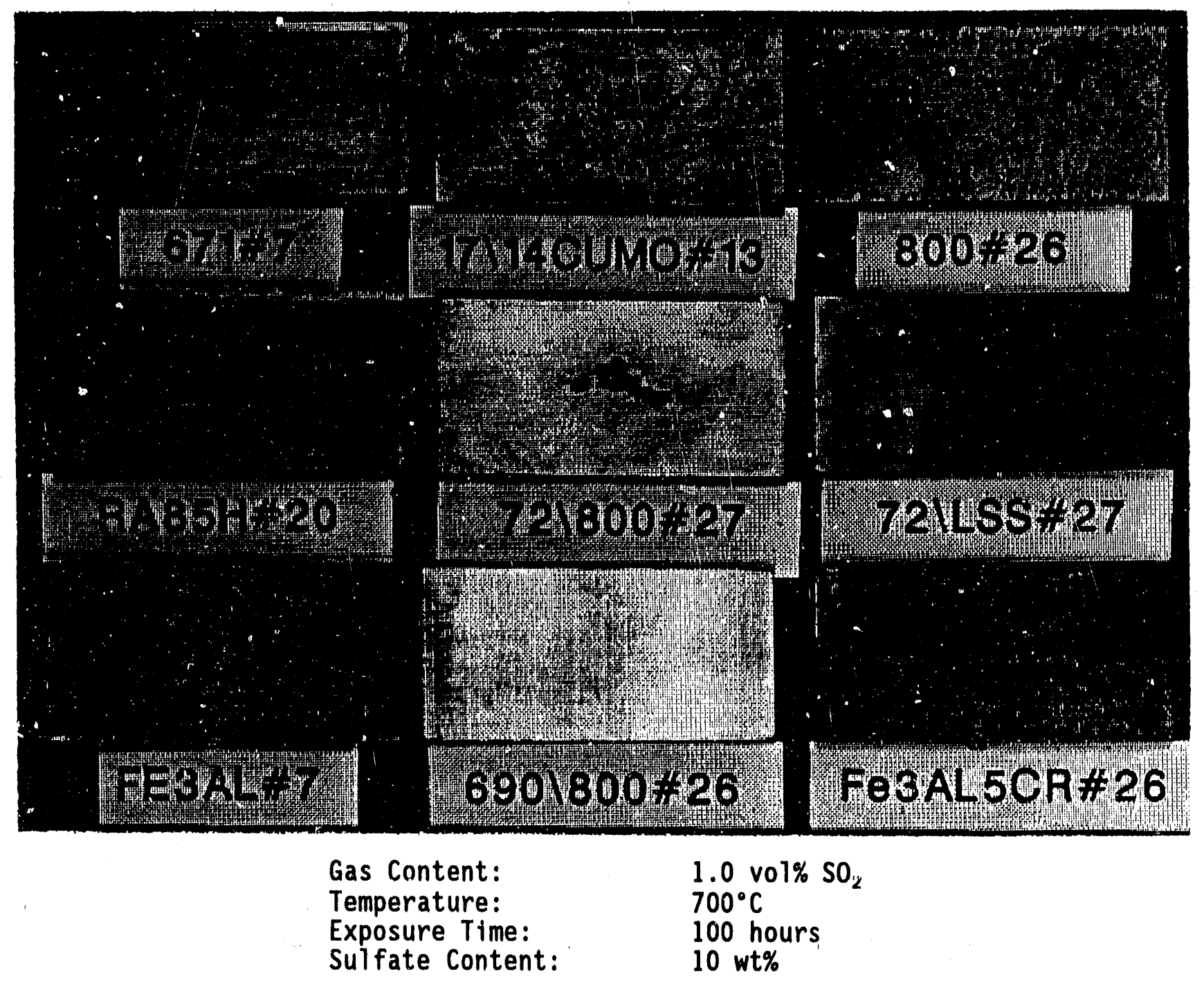


Recoated Between Exposures:

$\begin{array}{llllll}\mathrm{Fe}_{3} \mathrm{Al}-5 \mathrm{Cr}-21 & 556-20 & 72 / 800 \mathrm{H}-21 & \mathrm{NF709-8} & 671 / 316-8 & \text { CR35A-21 } \\ 671 / 316-7 & \mathrm{HR3C}-20 & 690 / 316-20 & (\mathrm{FeNi})_{3} \mathrm{Al}-8 & 800 \mathrm{H}-21 & 316-8 \\ \text { SAN28-1 } & 690-21 & & & & \end{array}$

Steam Cleaned and Recoated Between Exposures:
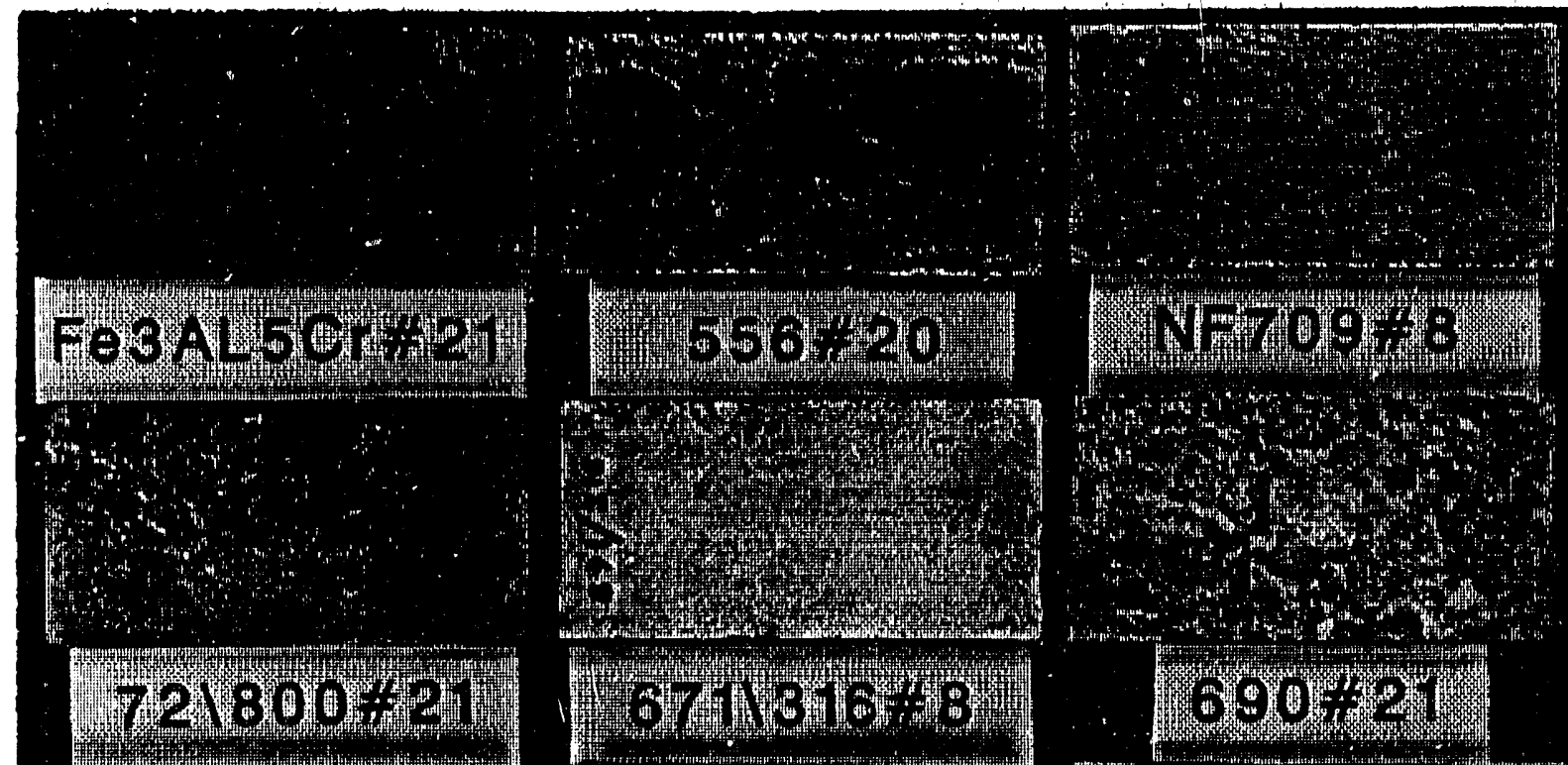

$721800 * 21$
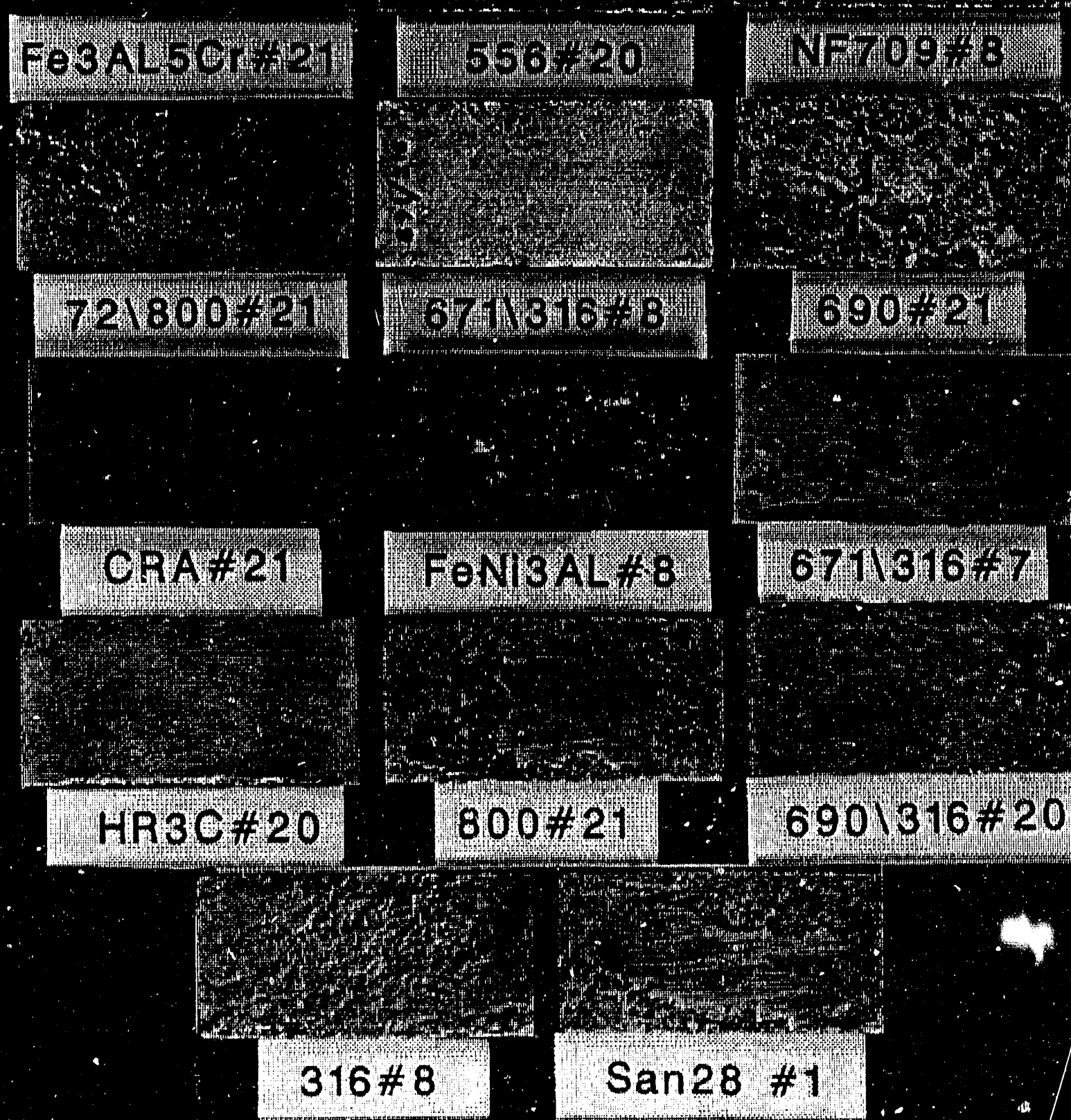

$6901316 \# 20$

Gas Content:

Temperature:

$0.25 \mathrm{vol}^{2} \mathrm{SO}_{2}$

Exposure Time:

Sulfate Content:

$700^{\circ} \mathrm{C}$

800 hours

$10 \mathrm{wt} \%$ 
Recoated Between Exposures:

17-14 CUMO-7

OSU-10
$\mathrm{Fe}_{3} \mathrm{Al}-5 \mathrm{Cr}-2 \mathrm{O}$

671-21
Steam Cleaned and Recoated

Between Exposures:

$\begin{array}{ll}\text { OSU-11 } & 347-8 \\ 671-22 & 17-14 \text { CUMO }-8 \\ \text { RABSH-8 } & 72 / 800 \mathrm{OH}-22 \\ 690 / 3 \times 6-21 & 72 / \text { LSS }-22\end{array}$

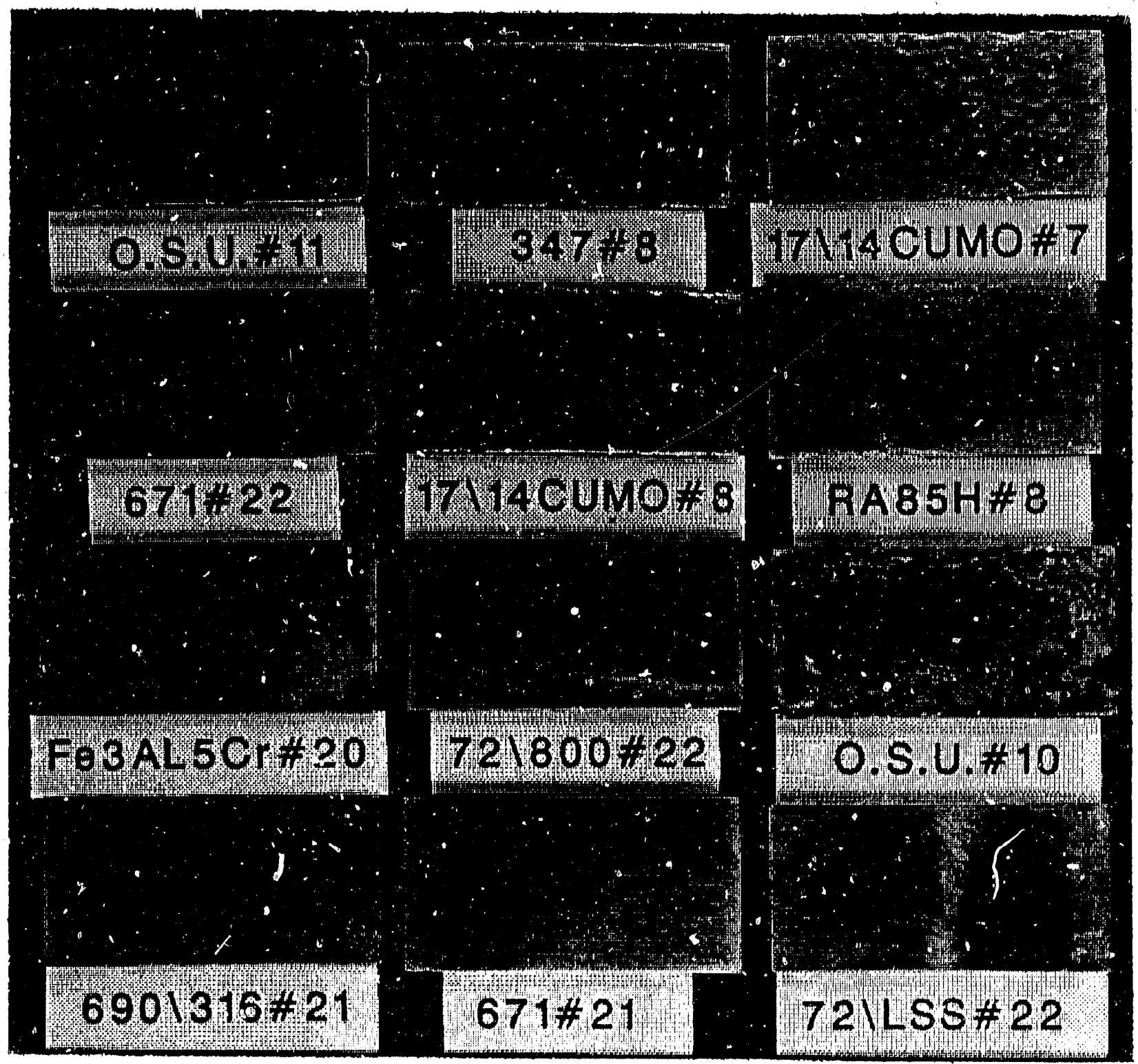

Gas Content:

Temperature:

$0.25 \mathrm{vol}^{2} \mathrm{SO}_{2}$

Exposure Time:

$700^{\circ} \mathrm{C}$

Sulfate Content:

800 hours

$10 \mathrm{wt} \%$ 
Recoated Between Exposures:

$\begin{array}{ll}690 / 800 \mathrm{H}-20 & \text { CR35A-20 } \\ \text { RA85H-7 } & 347-7 \\ 316-7 & \text { NF709-7 } \\ \text { (FeNi) }{ }_{3} \text { Al }-7 & 72 / \text { LSS-21 }\end{array}$

Steam Clearied and Recoated Between Exposures:

HR3C -21

$690 / 800 \mathrm{H}-21$

$556-21 \quad 690-22$

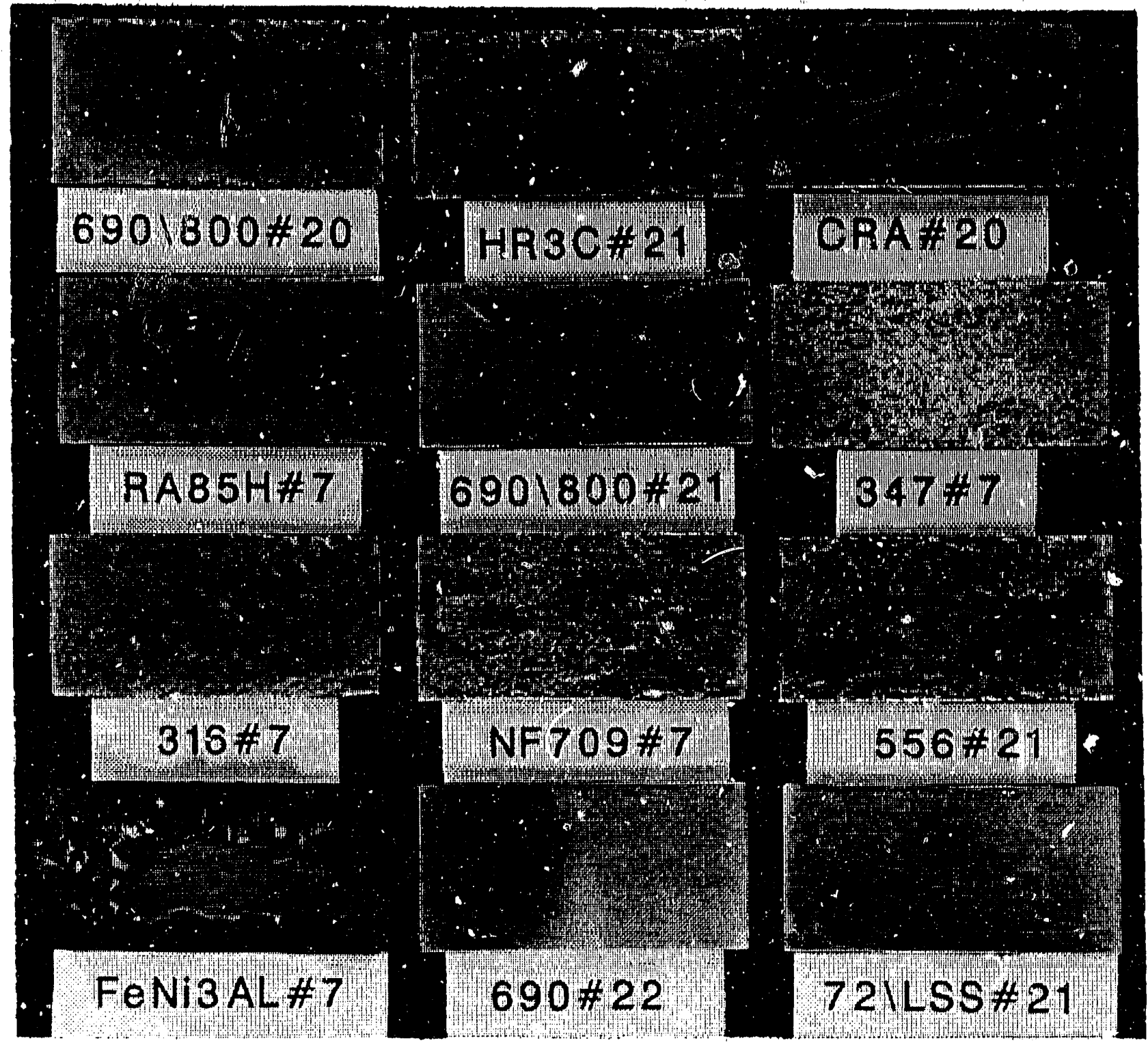

Gas Content:

Temperature:

Exposure Time:

Sulfate Content:

\subsection{5 vol\% $\mathrm{SO}_{2}$ $700^{\circ} \mathrm{C}$ \\ 800 hours \\ 10 wt\%}


Recoated Between Exposures:

$\begin{array}{ll}\text { RA85H-4 } & \text { SAN28-4 } \\ \text { NF709-4 } & \text { OSU -2 }\end{array}$

Steam Cleaned and Recoated Between Exposures:
RA85H-5
NF709-5
SAN28-5

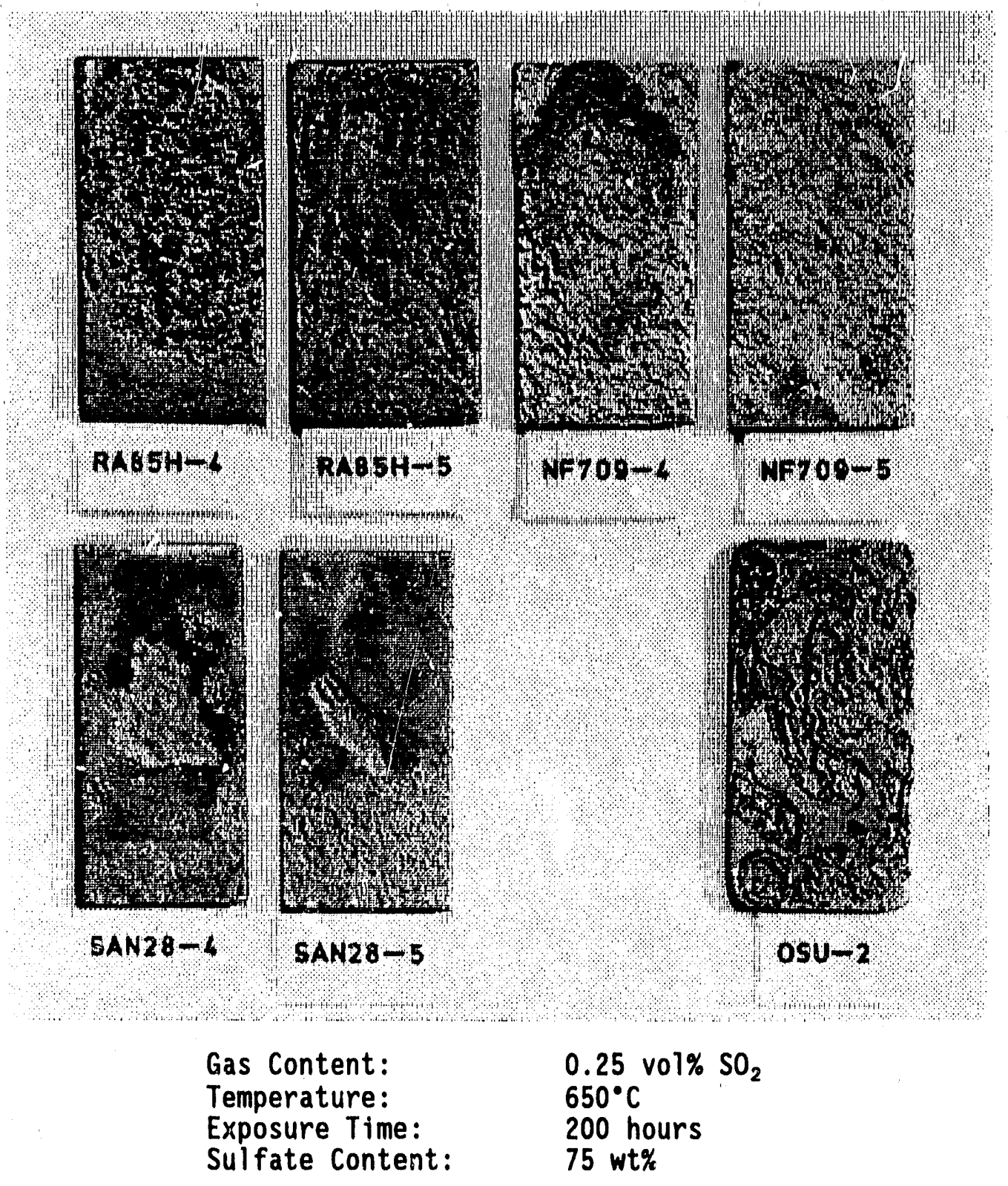


Recoated Between Exposures:

$671 / 316-4$

$671-4$
690/316-4

$690-4$
Steam Cleaned and Recoated

Between Exposures:

671/316-5

$671-5$

$690 / 316-5$

690-5

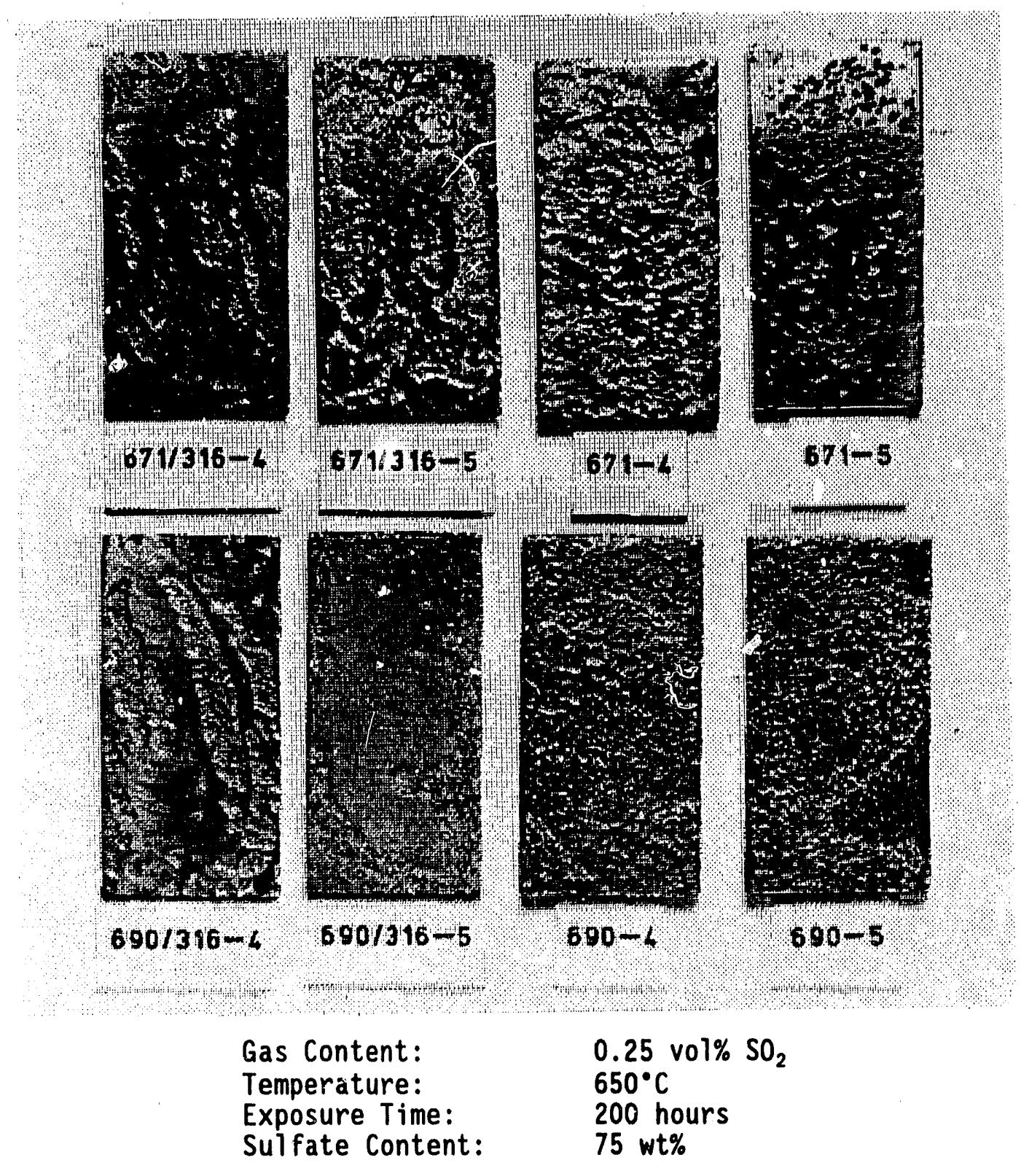


Recoated Between Exposures:

$\mathrm{Fe}_{3} \mathrm{Al}-4$
(FeNi) ${ }_{3} \mathrm{AT}-4$
Steam Cleaned and Recoated Between Exposures:

$\mathrm{Fe}_{3} \mathrm{Al}-5$

(FeNi) ${ }_{3} \mathrm{Al}-5$

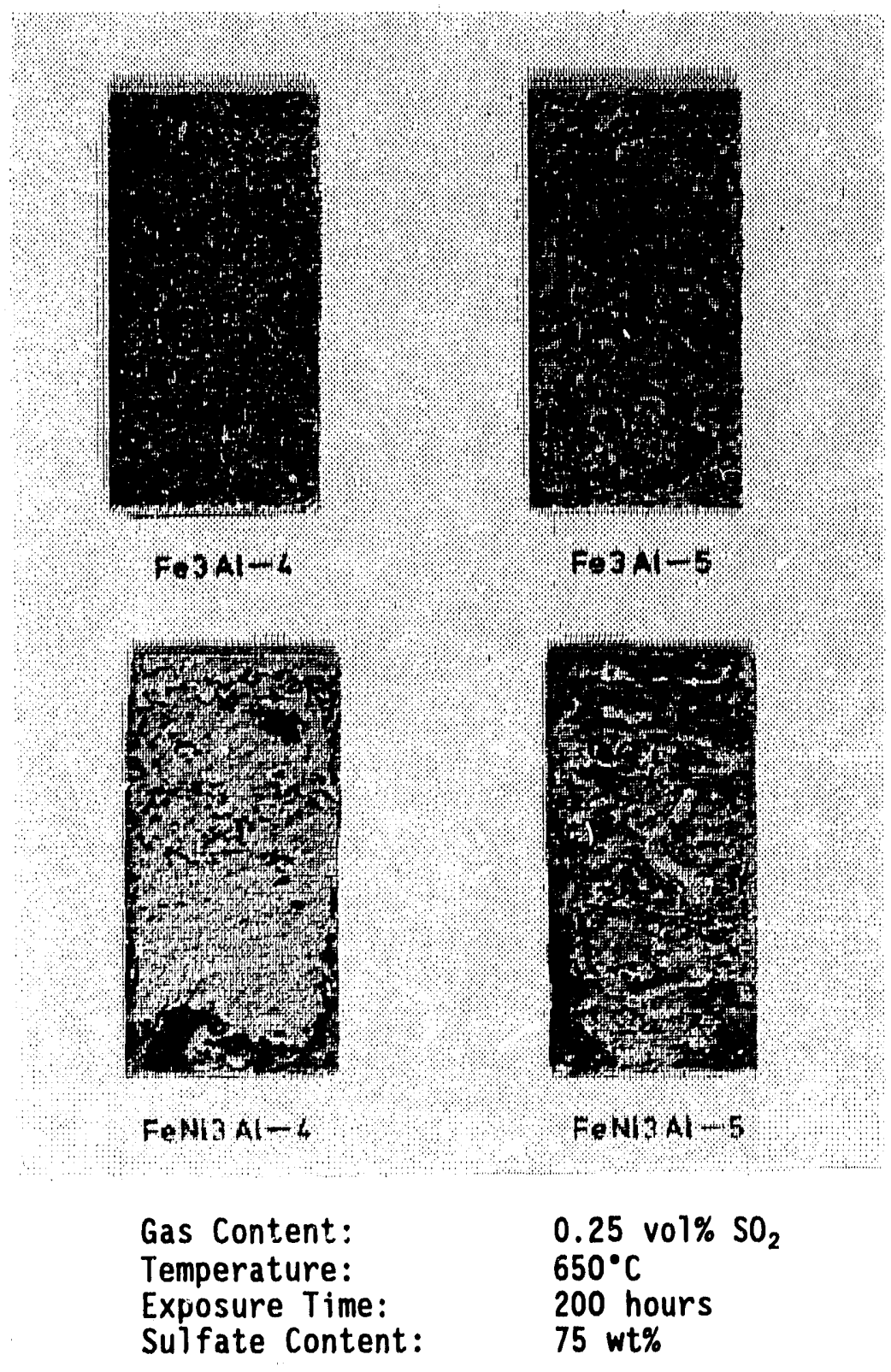


Reccited Between Exposures:

17-14 CUMO-4

$347-4$
CR35A-4

316-4
Steam Cleaned and Recoated

Between Exposures:

17-14 CuMo-5

$347-5$

CR35A-5

316-5

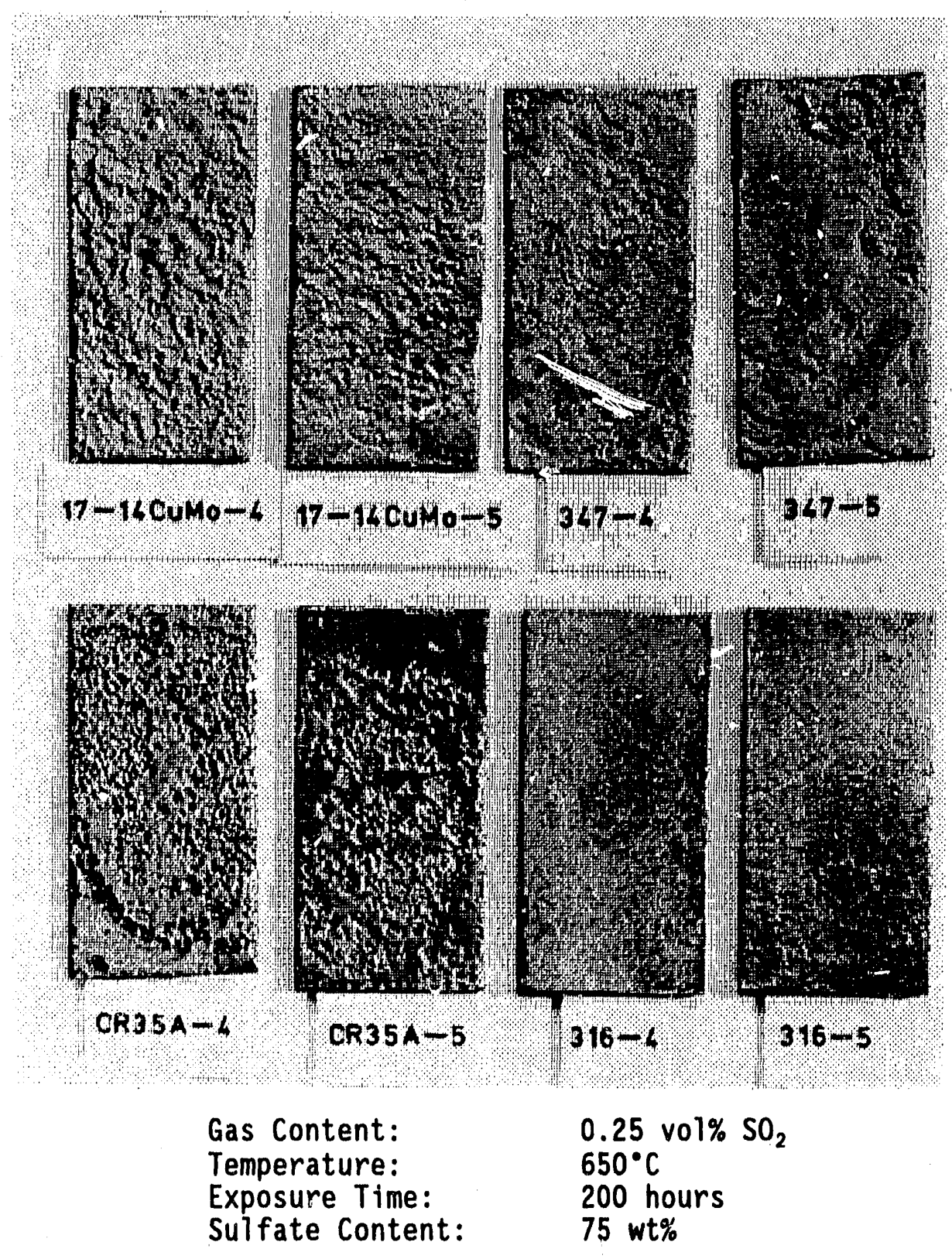


Recuated Between Exposures:

$800 \mathrm{H}-7$

$80 \mathrm{OH}-10$ *
$69 \mathrm{C} / 80 \mathrm{OH}-4$

$72 / 80 \mathrm{OH}-4$
Stean Cleaned and Recoated Between Exposures:

$80 \mathrm{OH}-8$

$800 \mathrm{H}-11$ *
$690 / 800 \mathrm{H}-5$

$72 / 800 \mathrm{H}-5$

["Coated with a coal ash containing 10 wt\% alkali sulfates.]

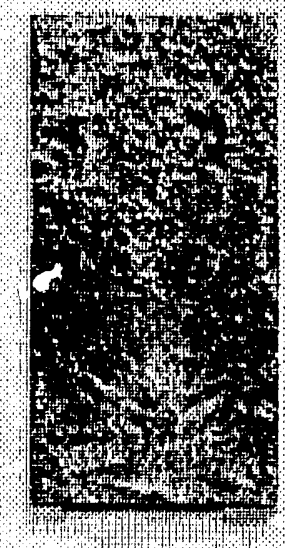

$800-7$

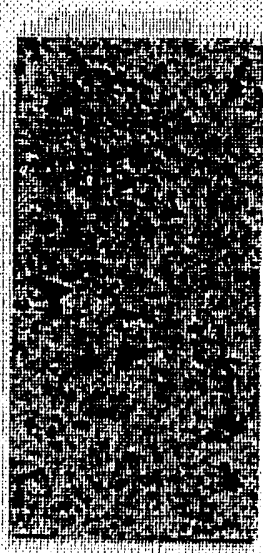

$6.901800-4$

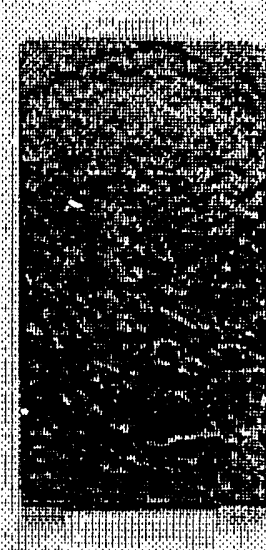

Boo $=8$

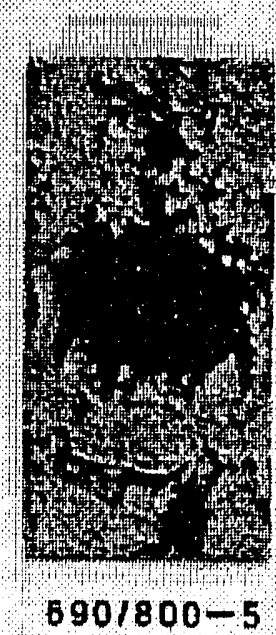

$6901800-5$
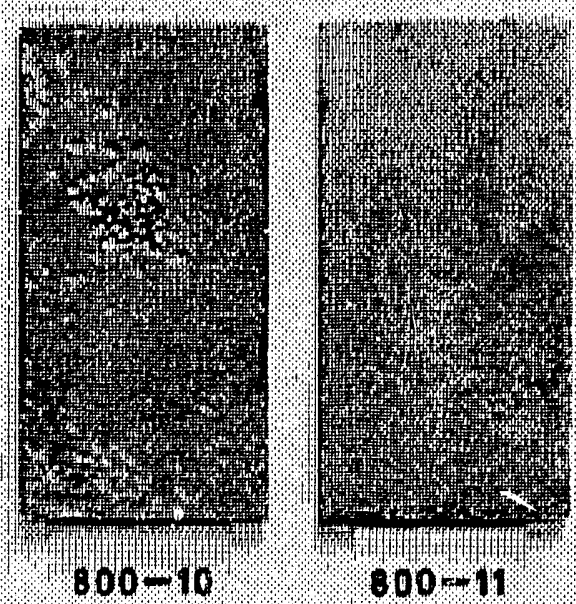

$800-11$

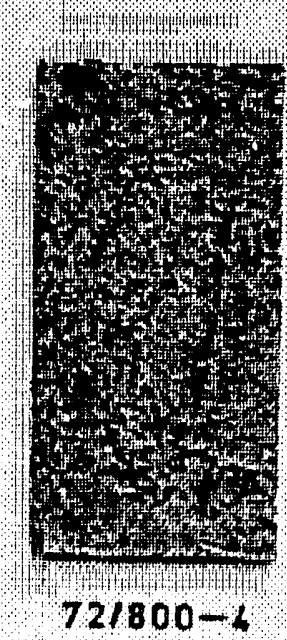

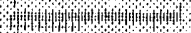

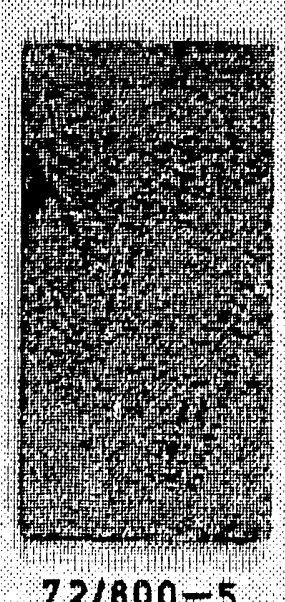

$72 / 800-5$

Gas Content:

Temperature:

0.25 vol\% $\mathrm{SO}_{2}$

Exposure Time:

Sulfate Content:

$650^{\circ} \mathrm{C}$

200 hours

$75 \mathrm{wt} \%$ 
Recoated Between Exposures:

$\begin{array}{ll}72 / 800 \mathrm{H}-25 & 72 / \text { LSS }-24 \\ 556-23 & \text { OSU }-13 \\ \text { RA85H-10 } & \text { SAN28-2 } \\ 690 / 800 \mathrm{H}-23 & (\mathrm{FeNi})_{3} \mathrm{AT}-9\end{array}$

Steam Cleaned and Recoated Between Exposures:

NF709-10

72/LSS-25

$800 \mathrm{H}-24$

(FeNi) ${ }_{3} \mathrm{Al}$ - 10

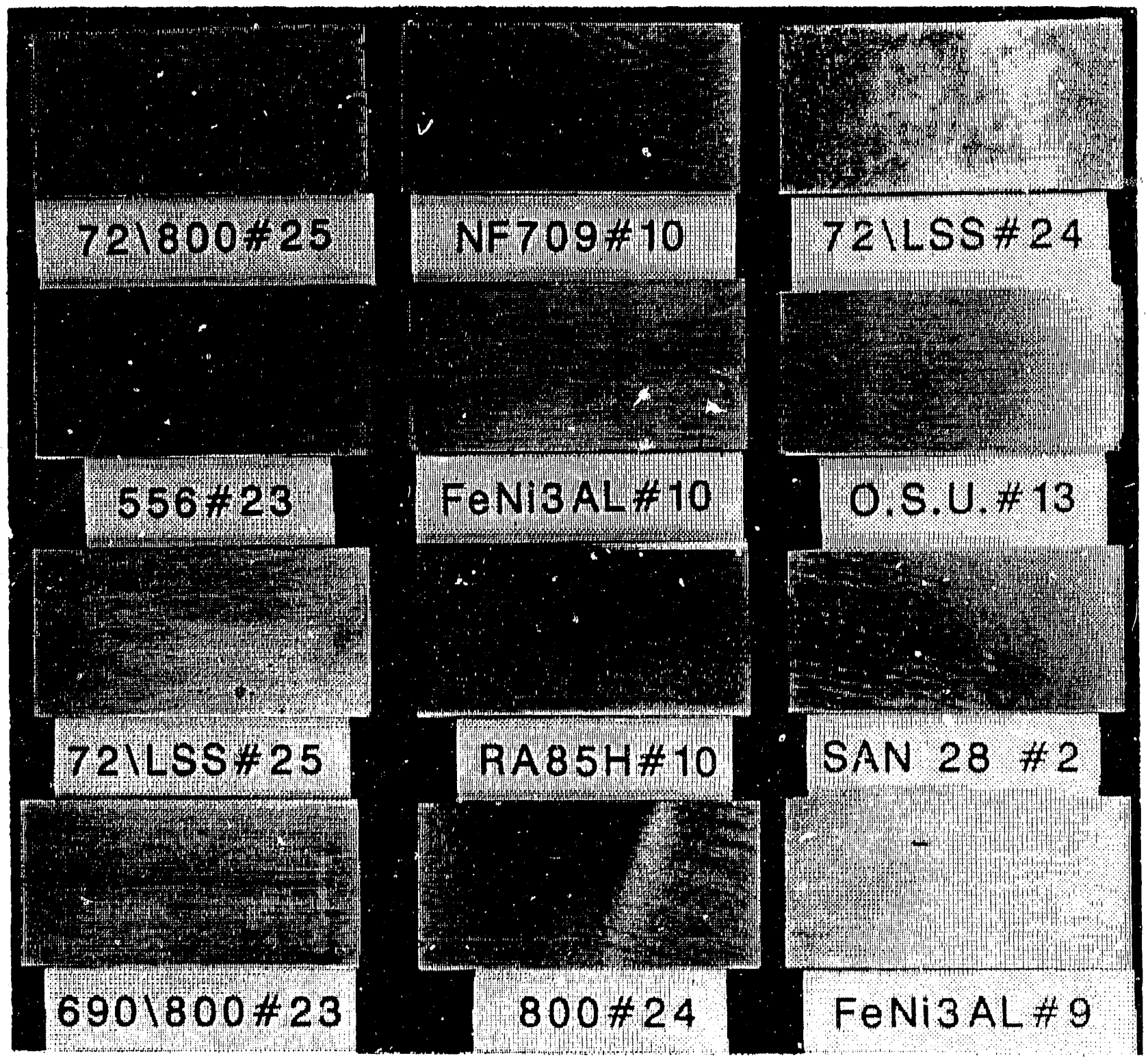

Gas Content:

Temperature:

Exposure Time:

Sulfate Content:
0.25 vol\% $\mathrm{SO}_{2}$

$650^{\circ} \mathrm{C}$

800 hours

10 wt\% 
Recoated Between Exposures:

$\mathrm{Fe}_{3} \mathrm{Al}-5 \mathrm{Cr}-23$ NF709-9

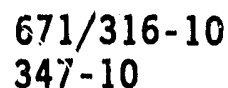

$72 / 800 \mathrm{H}-24$

17-14 CUMo-10
Steam Cilearred and Recoated Between Exposures:
CR35A-8
HR3C-24
OSU-14 556-24
17-14 CUMo-11
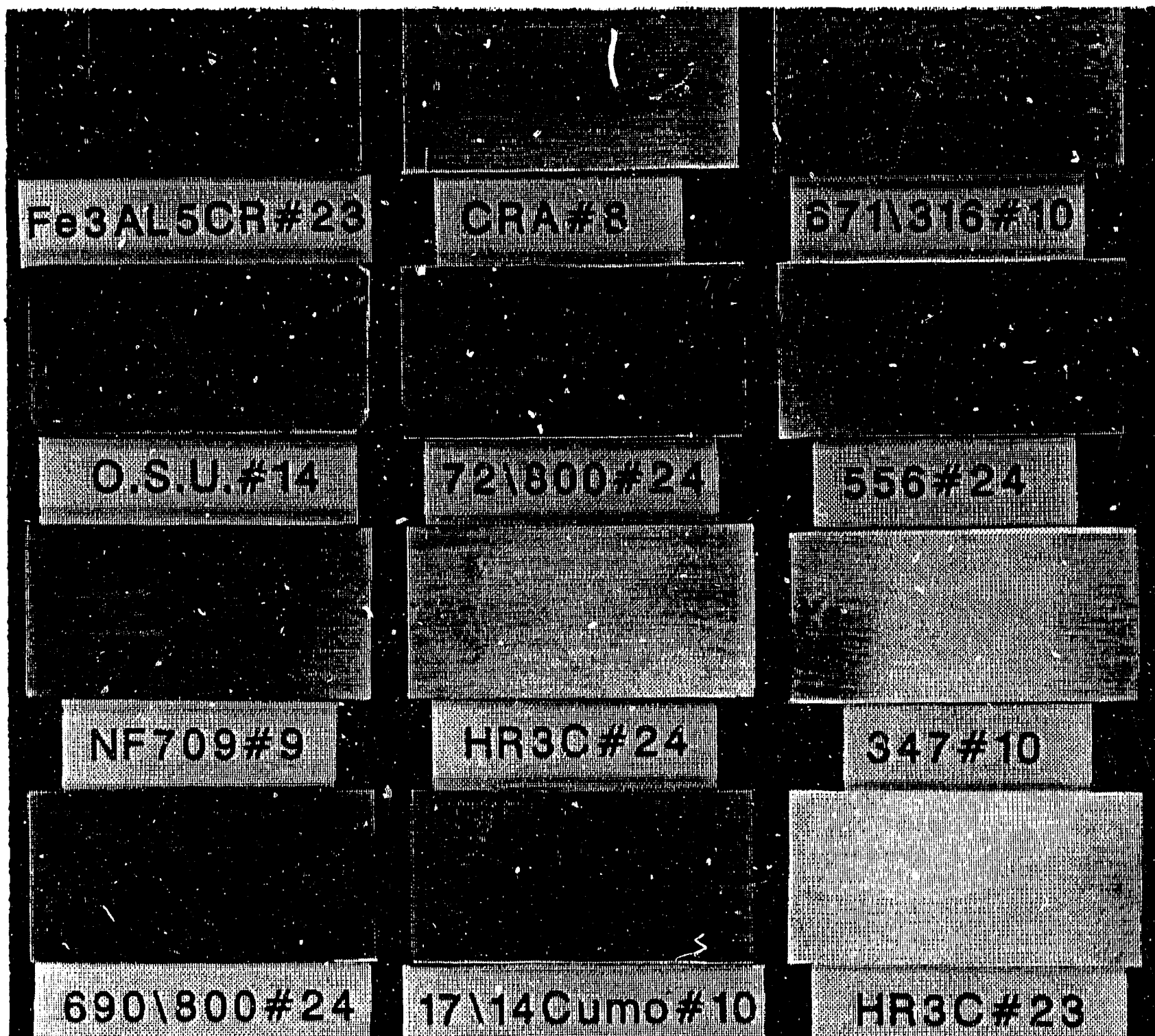

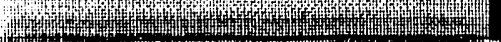
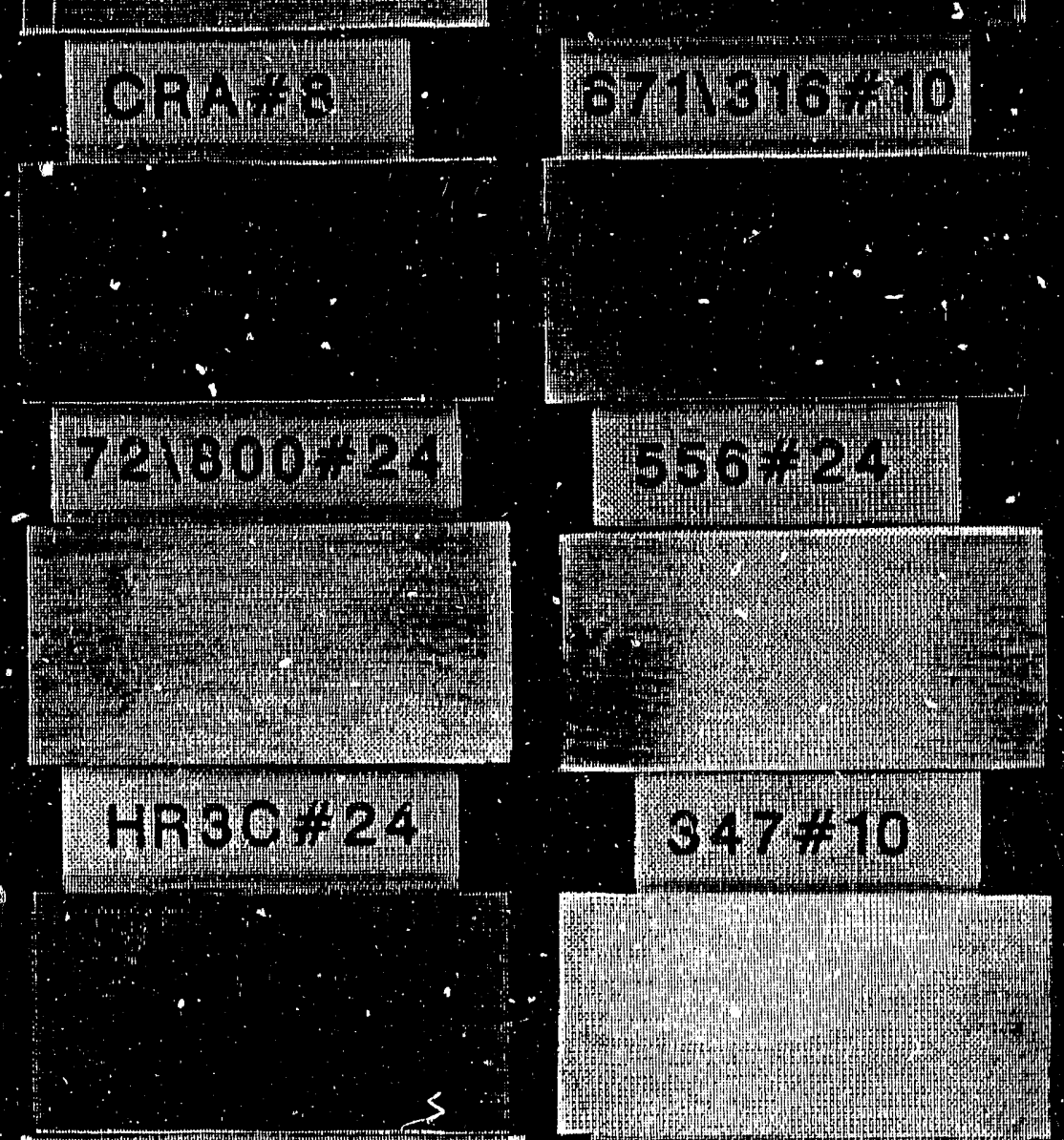

17114 cumo $* 10$
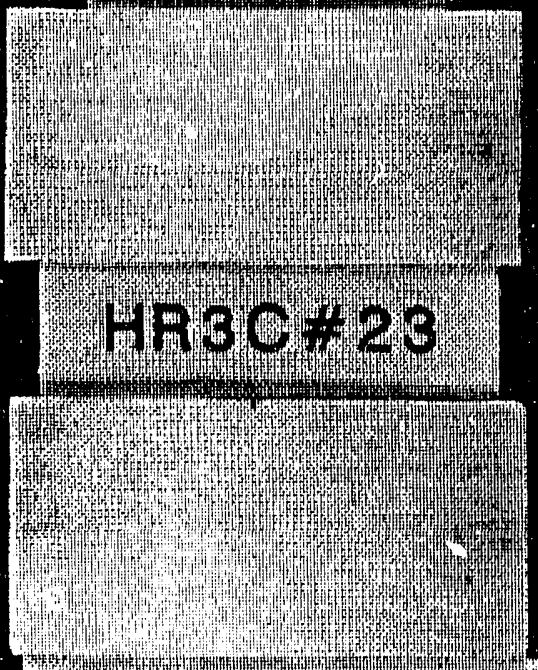

$6901316 \# 24$

$17 \mathrm{~V} 14 \mathrm{Cumo} \# 11$

Gas Content:

Temperature:

Exposure Time:

Sulfate Content:
$0.25 \mathrm{vol}_{2} \mathrm{SO}_{2}$

$650^{\circ} \mathrm{C}$

800 hours

$10 \mathrm{wt} \%$ 
Recoated Between Exposures:

$\begin{array}{ll}690-24 & \text { CR35A-7 } \\ 316-10 & 800 \mathrm{H}-23 \\ 671-24 & 690-316-23\end{array}$

Steam Cleaned and Recoated Between Exposures:

316-11

347-11

$690-25$

RA85H-11

$$
\left.\mathrm{Fe}_{3} \mathrm{~A}\right]-5 \mathrm{Cr}-24
$$

$671 / 316-23$

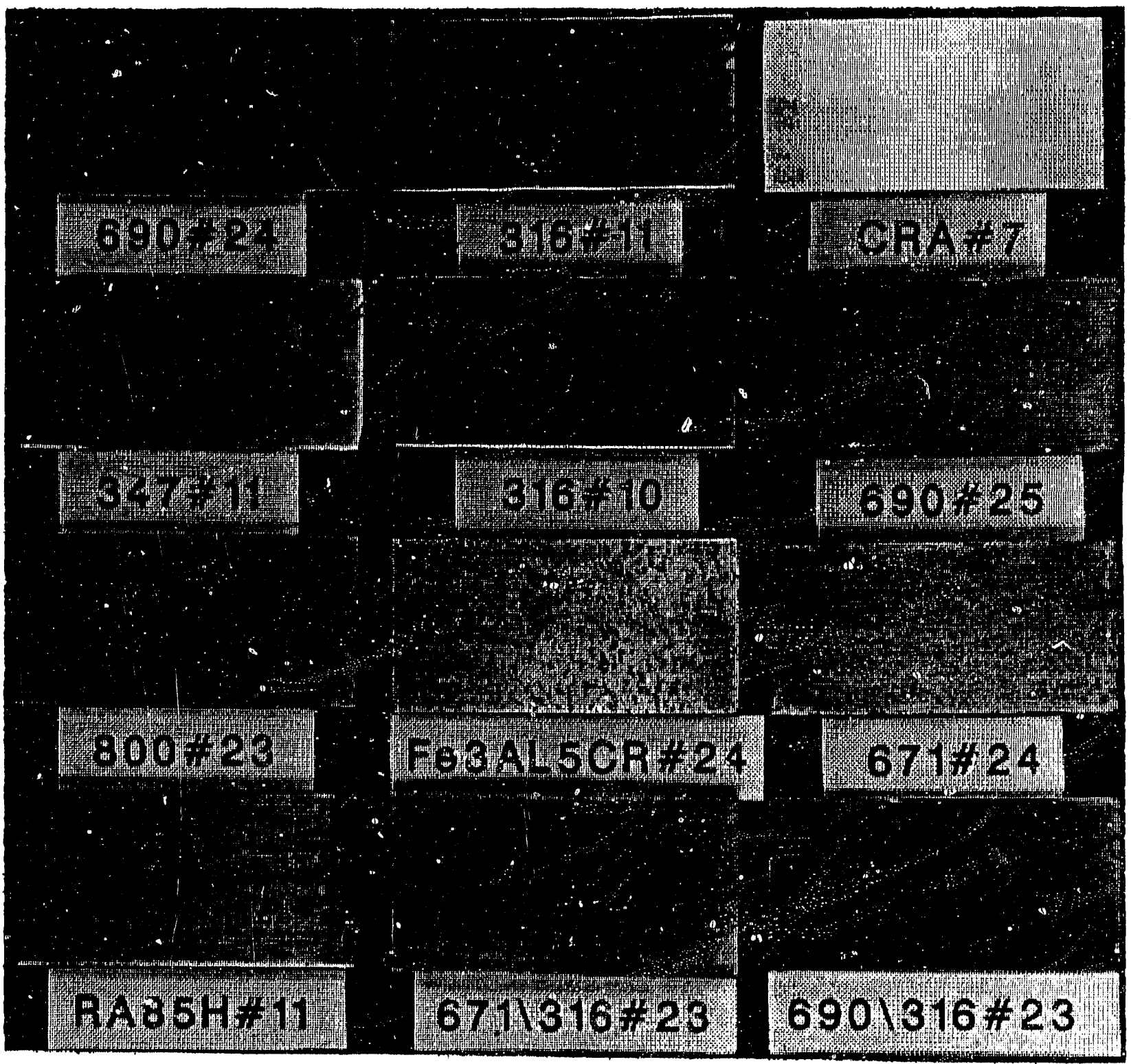

Gas Content:

Temperature:

Exposure Time:

Sulfate Content:
$0.25 \mathrm{vol}_{\mathrm{SO}} \mathrm{SO}_{2}$

$650^{\circ} \mathrm{C}$

800 hours

10 wt\% 


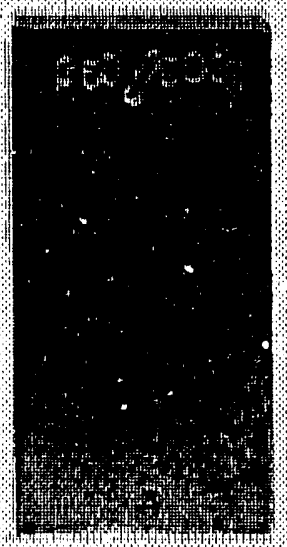

$6711316-3$

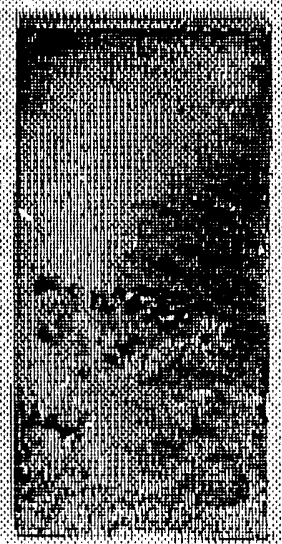

$721800-3$

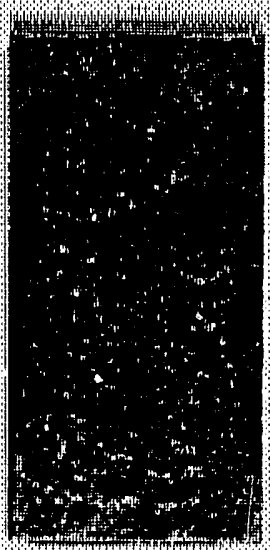

$316-8$

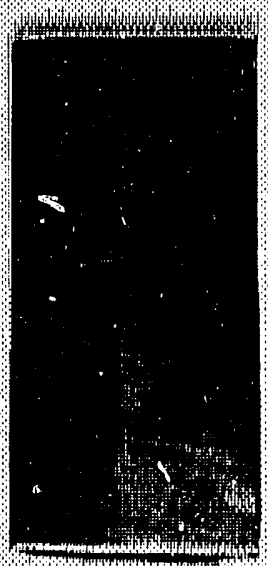

671.3

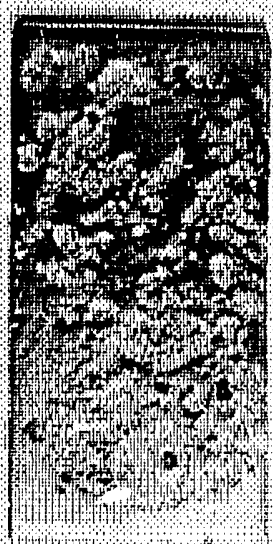

$690-3$

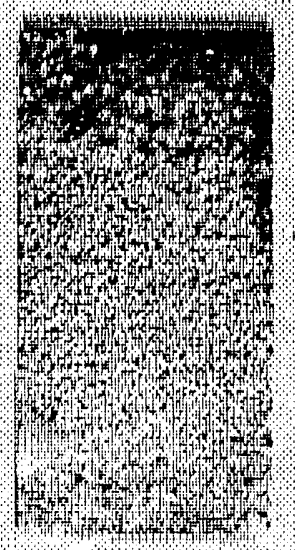

IN $800-3$

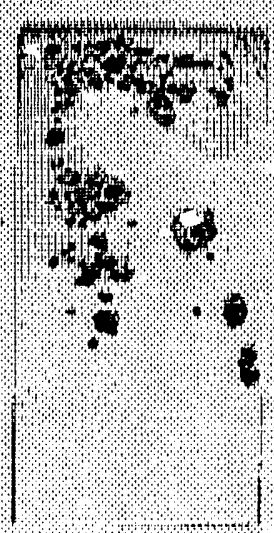

$\mathrm{Cr} 35 \mathrm{~A}-3$
Gas Content:

Temperature:

Exposure Time:

Sulfate Content:
0.25 vol\% $\mathrm{SO}_{2}$

$700^{\circ} \mathrm{C}$

100 hours

$75 \mathrm{wt} \%$ 


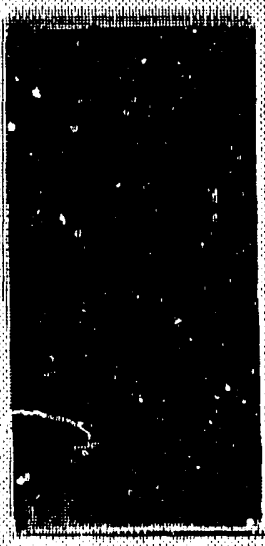

$690 / 316-3$

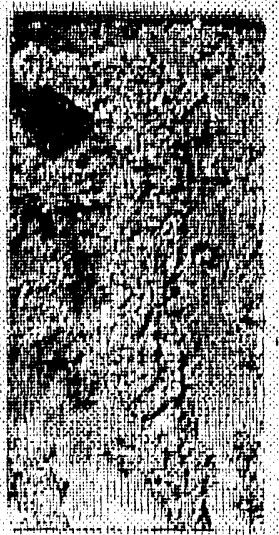

NF7 $09-3$

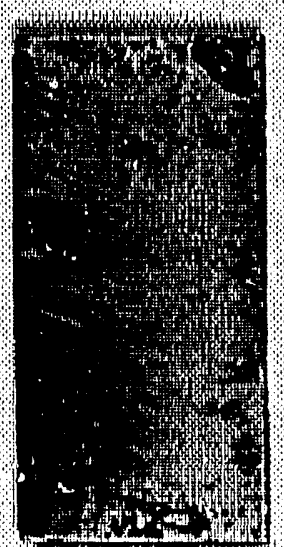

Fe3Al -3

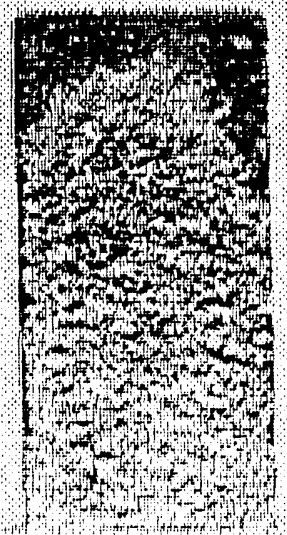

$17-14 \mathrm{CuMO}-3$

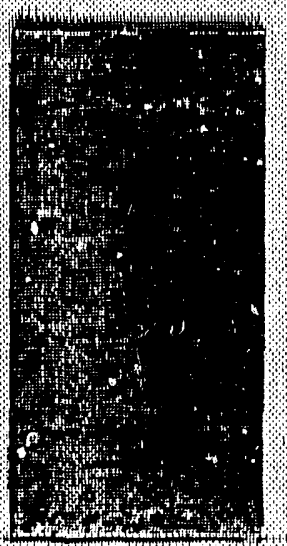

FeNI3 Al-3
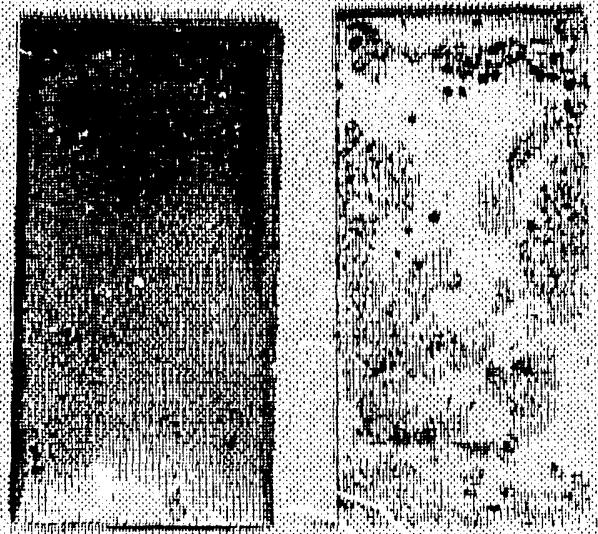

RAB $5 H-14$

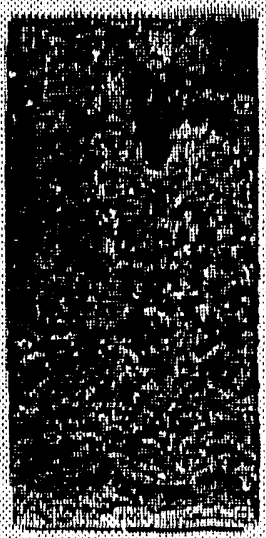

$347-14$

Gas Content:

Temperature:

0.25 vol\% $\mathrm{SO}_{2}$

Exposure Time:

Sulfate Content:

$700^{\circ} \mathrm{C}$

100 hours

$75 \mathrm{wt} \%$ 


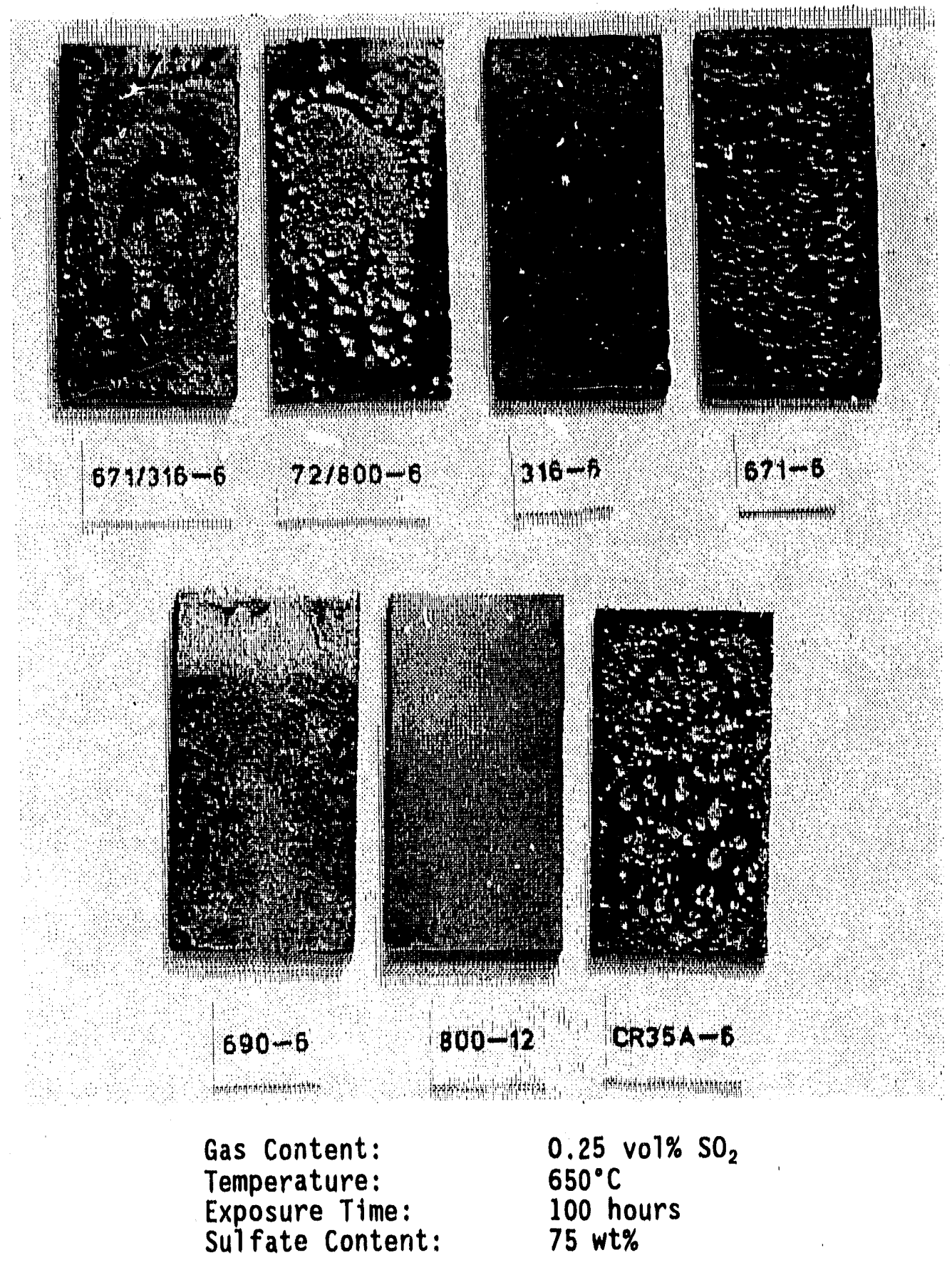




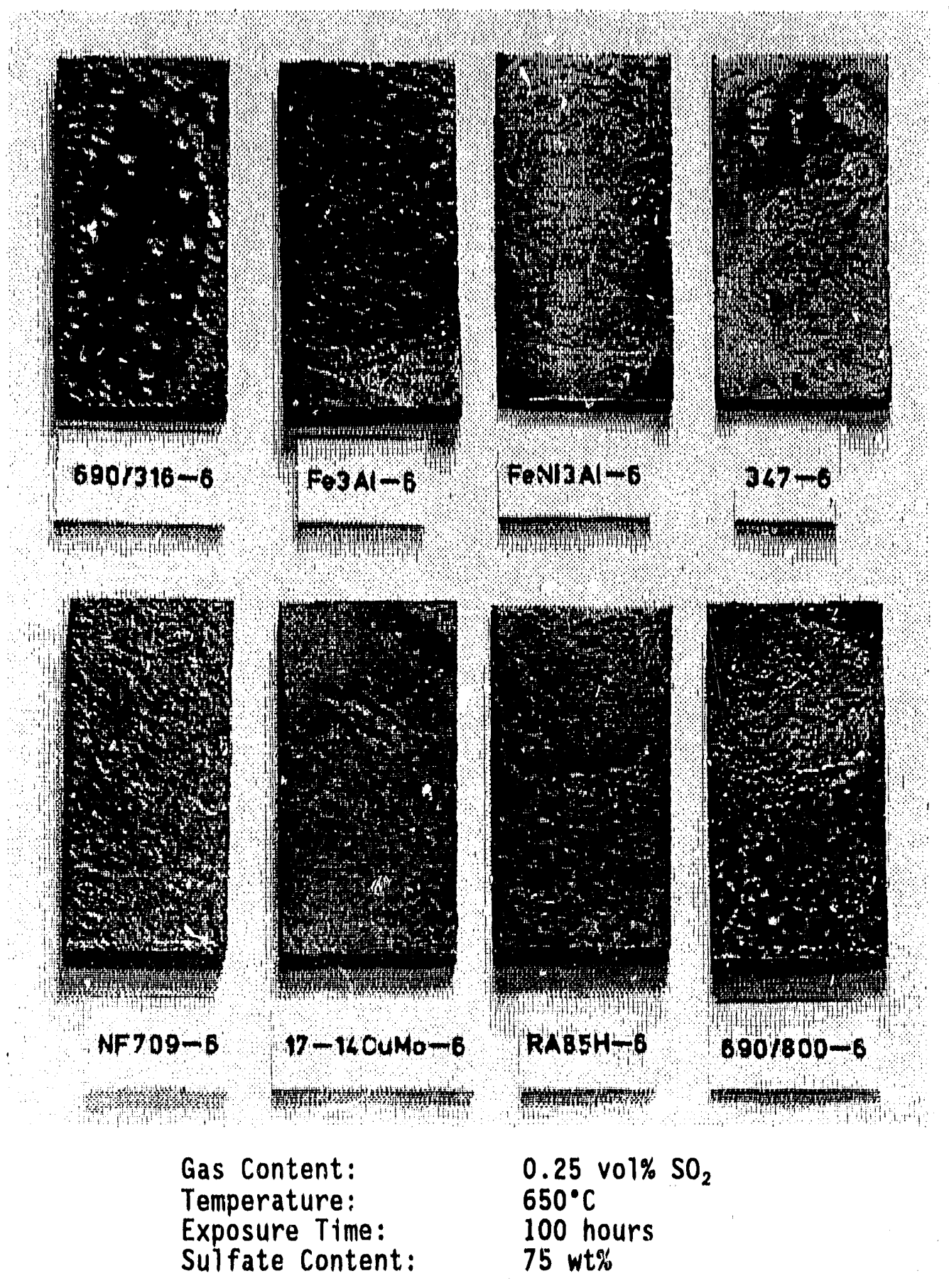




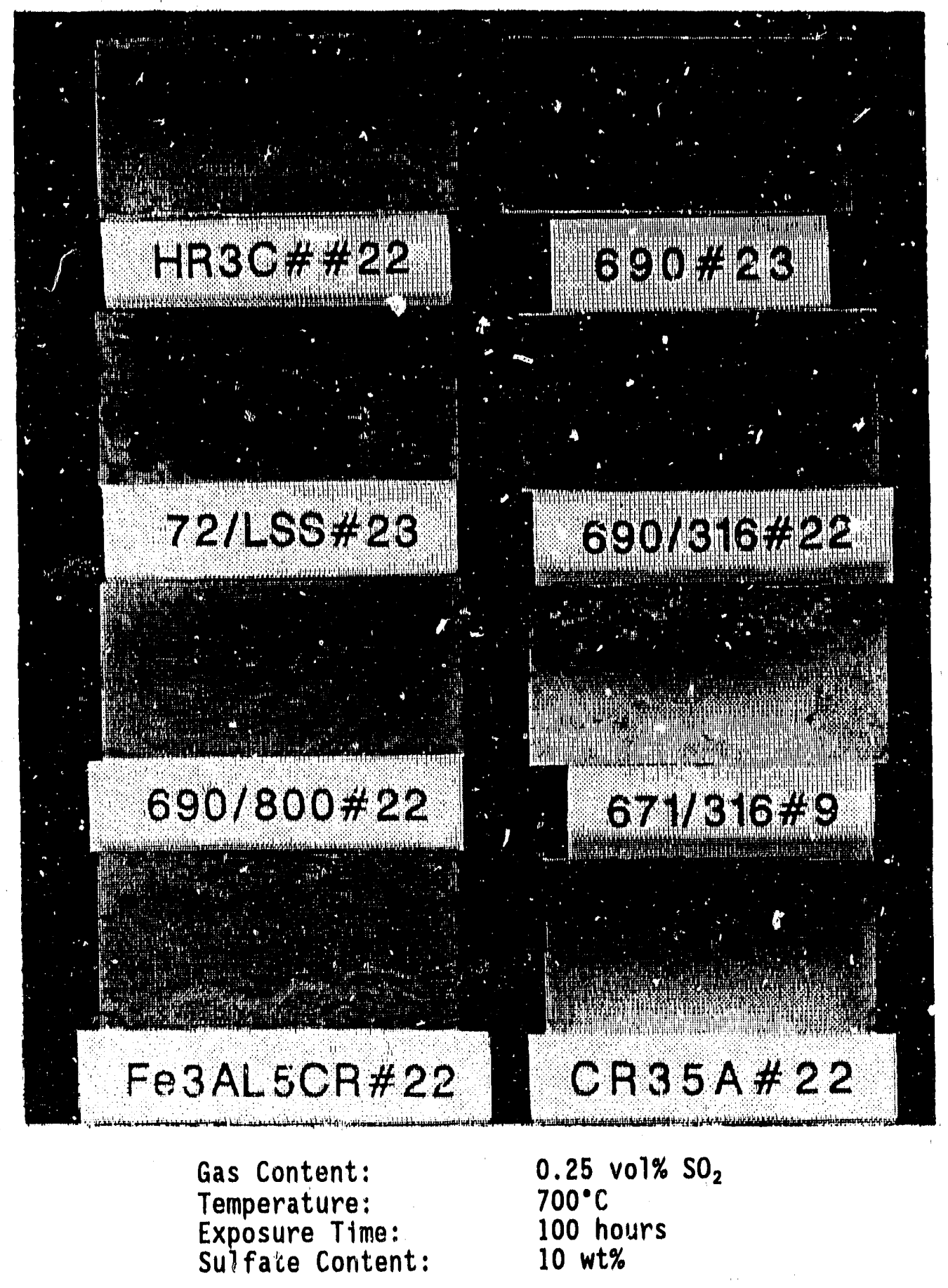




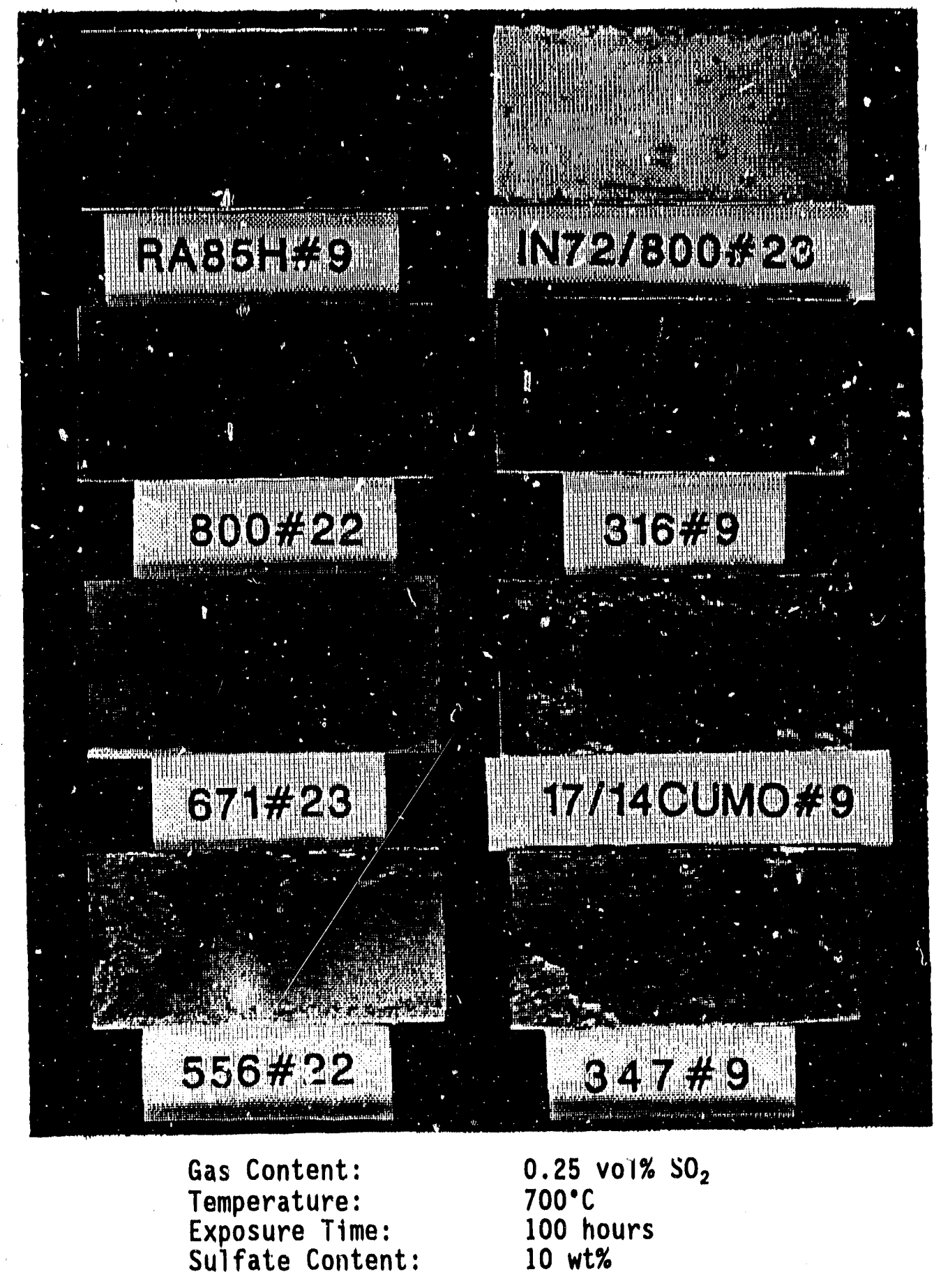




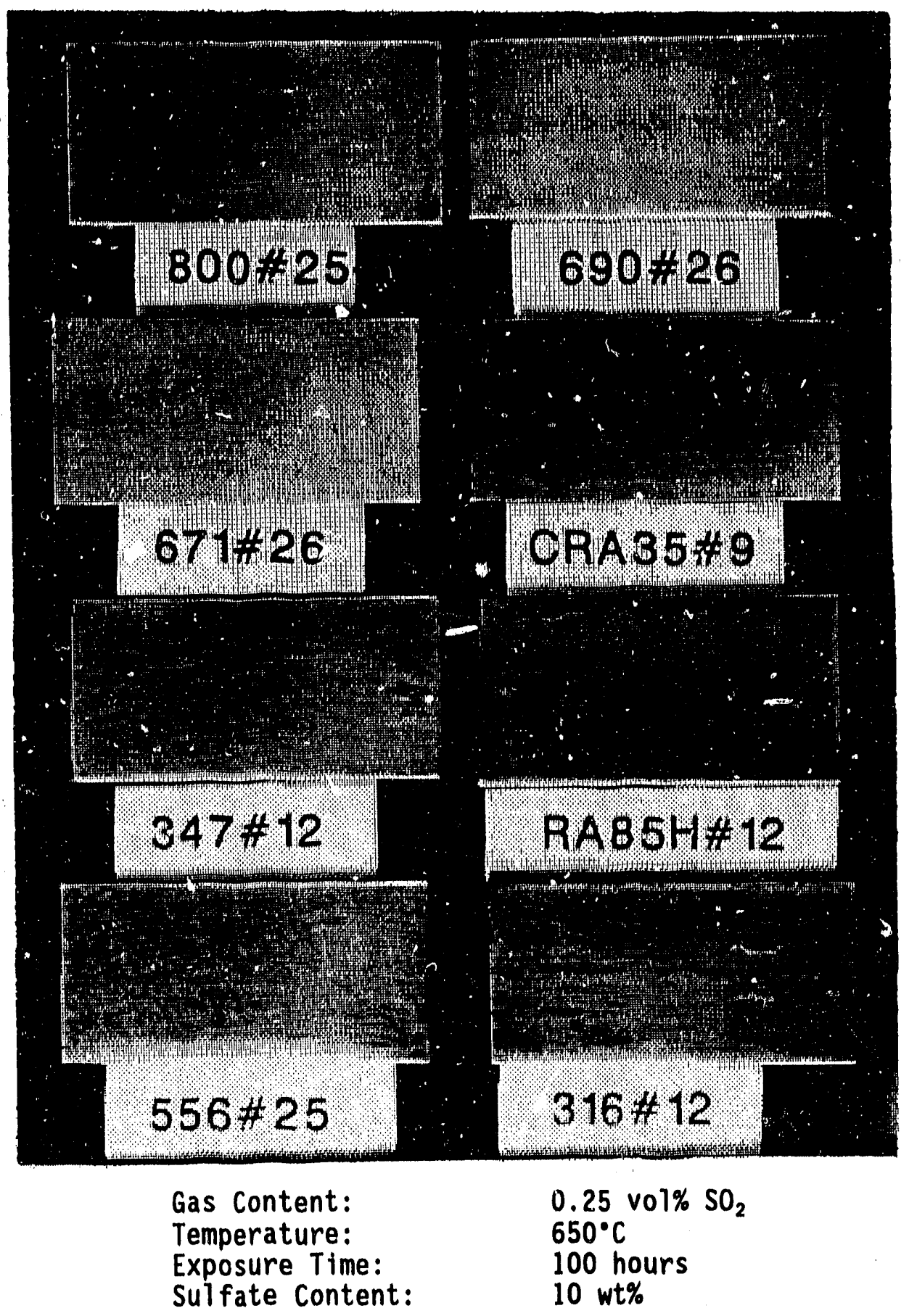




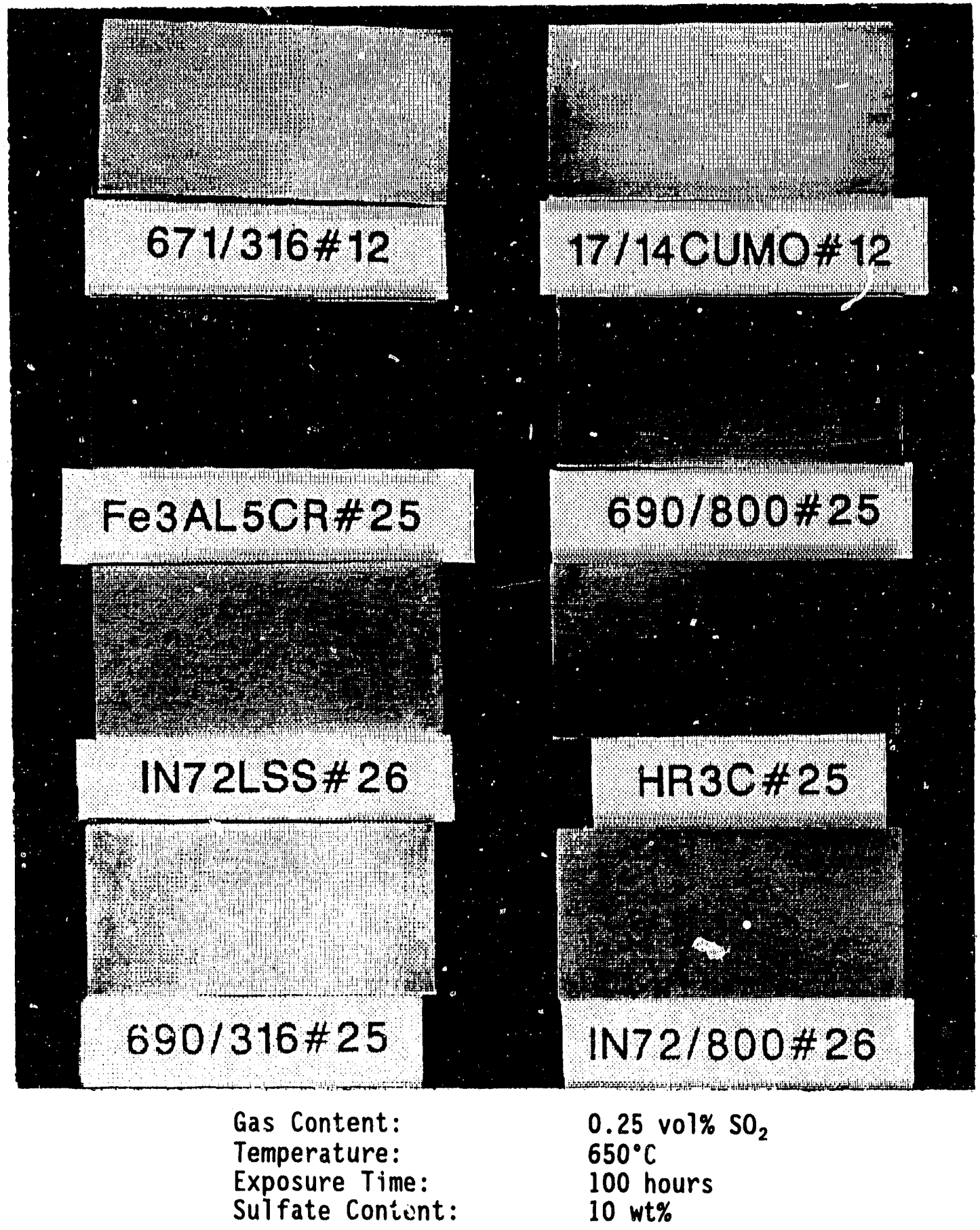


APFENDIX B 


\section{DISTRIBUTION}

AIR PRODUCTS AND CHEMICALS

P. O. Box 538

Allontown, PA 18105

S. W. Dean

S. C. Woiner

ALBERTA RESEARCH COUNCIL

Oll Sands Research Dopartment

P.O. Box 8330, Postal Station F

Edmonton, Alberta

Canada T6H5X2

L. G. S. Gray

AULSON GAS TURBINE DIVISION P. O. Box 420 Indianapolis, IN 46206-0420

P. Khandolwal (Speed Code W-5)

R. A. Wonglerz (Spoed Code W-16)

AMAX R\&D CENTER

5950 Molntyre Stroot

Golden, CO 80403

T. B. Cox

ARGONNE NATIONAL LABORATORY

9700 S. Cass Avenue

Argonne, IL 60439

W. A. Ellingson

K. Natesan

ARGONNE NATIONAL LABORATORY-WEST

P. O. BOX 2528

Idaho Falls, ID 83403-2528

S. P. Hensioe

\section{AVCO RESEARCH LABORATORY \\ 2385 Revere Beach Parkway \\ Everett, MA 02149 \\ R. J. Pollina}

\section{BABCOCK \& WILCOX}

1562 Beeson St.

Alliance, $\mathrm{OH} 44601$

T. I. Johnson

\section{BABCOCK \& WILCOX}

Domestio Fossil Operations

20 South Van Buren Ave.

Barberton, OH 44023

M. Gold

BATTEUE-COLUMBUS LABORATORIES

$505 \mathrm{King}$ Avenue

Columbus, OH 43201

V. K. Sothi

I. G. Wright
BETHLEHEM STEEL CORPORATION

Homer Research Laboratory

Bethlohem, PA 18016

B. L. Bramfitt

J. M. Chilton

BATTSH COAL CORPORATION

Cool Researoh Establishment

Stoke Orohard, Choltenham

Glouchester, England GL52 4RZ

M. Arnold

C. Bower

A. Twigg

BRITISH GAS CORPORATION

Westfiold Development Contre

Cardenden, Fifo

Scotland KY5OHP

J. E. Scott

BROOKHAVEN NATIONAL LABORATORY

Dopartment of Appliod Soionoe

Upton, Long leland, NY 11973

T. E. O'Hare

CANADA CENTER FOR MUNERAL ENERGY TECHNOLOGY

568 Booth Stroot

Ottawa, Ontario

Canada K1A OG 1

R. Winston Rovie

Mahi Sahoo

COLOAADO SCHOOL OF MMES

Department of Metallurgical Engineoring

Golden, CO 80401

G. R. Edwards

COMBUSTION ENGINEERING

911 W. Main Street

Chattanooga, TN 37402

D. A. Canonico

EC TECHNOLOGIES INC.

3814 Highpoint Drive

San Antonio, TX 78217

D. J. Kenton

ELECTRIC POWER RESEARCH INSTITUTE

P.O. Box 10412

3412 Hillviow Avenue

Palo Alto, CA 94303

W. T. Bakker

J. T. Stringer

H. Wolk 
EUROPEAN COMAUNTIES JOINT RESEARCH CENTRE Potton Establishmont

P. O. Box 2

1755 ZG Potton

The Netheriands

$M$. Van de Voordo

FOSTER WHEELER DEVELCPMENT CORPORATION

Materials Toohnology Dopertment

John Blizard Researoh Conter

12 Poech Troo Hill Road

Livingston, NJ 07039

J. L. Blough

IDAHO NATIONAL ENGINEERING LABORATORY

P.O. Box 1625

Ideho Falls, ID 83415

D. W. Koefor

R. N. Wright

LAWRENCE UVERMORE LABORATOAY

P.O. BOX 808, L-325

Livermore, CA 94550

W. A. Stoole

NATIONAL INSTITUTE OF STANDARDS AND TECHNOLOGY

Materials Building

Gaithersburg, MD 20899

L. K. Ives

NATIONAL MATERIALS ADVISOAY BOARD

National Research Counoll

2101 Constitution Avenue

Washington, DC 20418

K. M. Zwilsky

NEW ENERGY AND INDUSTRIAL TECHNOLOGY DEVELOPMENT ORGANIZATION

Sunshine 60 Blde.

P.O. Box 1151, 1-1

Higeshi-lkebukuro 3-ohrome

Toshima-Ku, Tokyo, 170

Jepen

H. Narita/S. Uoda
OAK FIDGE NATIONAL LABORATORY

P. O. Box 2008

Oak Ridoo, TN 37831

P. T. Carleon

N.C. Colo

J. H. DoVan

R. R. Judkins

J. L. Langford (8 coples)

R. W. Swindeman

RESEARCH TRIAMGLE MSTTIUTE

P. 0. Box 12194

Research Triartole Park, NC 27709

T. W. Siamon

SHELL DEVELOPMENT COMPANY

P. O. Box 1380

Houston, TX 77251-1380

L. W. R. Dioke

THE JOHNS HOPKINS UNIVERSTY

Materials Soienoe \& Engineoring

Marviand Hall

Beltimore, MD 21218

R. E. Groen, Jr.

THE MATERIALS PROPERTIES COUNCIL, INC.

United Enginoering Center

345 E. Forty-Sovonth Stroot

Now York, NY 10017

M. Pragor

THE TORAINGTON COMPANY

Advenoed Technology Center

59 Fiold Stroot

Torrington, CT 06790

W. J. Chmura

UNION CAREIDE CORPORATION

Linde Division

P. O. Box 44

175 East Park Drive

Tonawanda, NY 14151.0044

Harry Choung

\section{UNIVERSTTY OF NOTRE DAME}

Department of Materials Scionoe and Engineering

P. O, Box E

Notro Dame, IN 46556

T. H. Kosol

UNIVERSTY OF TENNESSEE AT KNOXVUE

Materiale Science and Engineering Dopt.

Knoxvillo, TN 37996

R. A. Buchanan

C. D. Lundin 
UNIVERSITY OF TENNESSEE BPACE INSTITUTE

Tullahoma, TN 37388

J. W. Muohlhouser

\section{UNIVERSITY OF WABHINGTON}

Dopartment of Materials Solenoe and Engineering

101 Wilson, FB-10

Soottlo, WA 98195

T. G. Stoobe

WESTINGHOUSE ELECTAIC COAPORATION

Researoh and Devolopment Center

1310 Boulah Road

Pittsburgh, PA 15235

S. C. Singhal

WESTINGHOUSE HANFOAD COMPANY

P.O. 30x 1970, WIA.65

Rlohland, WA 99352

R. N. Johnson

DOE

IDAHO OPERATIONS OFFICE

P. O. Box 1625

Idaho Falls, ID 83415

R. B. Loop

DOE

DOE FIEID OFFICE, OAK RIDEE

P. O. Box 2001

Oak Ridge, TN 37831

Assistant Manager for Researoh and Davolopment

DOE

DOE FIELD OFFICE, OAK RIDGE

P. O. Box 2008

Bullding 4500N, MS 6269

Oak Ridge, TN 37831

E. E. Hoffman

DOE

OFFICE OF BASIC ENEROY $6 C I E N C E S$

Matorials Soienoes Division

ER-131 GTN

Washington, DC 20545

J. B. Darby

DOE

OFFICE OF CONSERVATION AND RENEWABLE ENEROY

CE-12 Forrostal Building

Washington, DC 20545

J. J. Eborhardt
DOE

OFFICE OF FOSBIL ENEROY

Washington, DC 20545

D. J. BoooY (FE-14) GTN

J. P. Carr (FE-14) GTN

F. M. Glaeer (FE-14) GTN

DOE

MORGANTOWN ENEROY TECHNOLOGY CENTER

P. O. Box 880

Morgantown, WV 28505

R. A. Bajura

R. C. Bodlok

D. C. Clooro

F. W. Crouse, Jr.

N. T. Holoombo

W. J. Huber

M. J. Mayfiold

J. E. Noteatoin

J. S. Wilson

DOE

PITTSBUROH ENEROY TECHNOLOOY CENTER

P. O. Box 10940

Pittsburgh, PA 15236

A. H. Baldwin

G. V. MoGurl

R. Santore

T. M. Torkos 

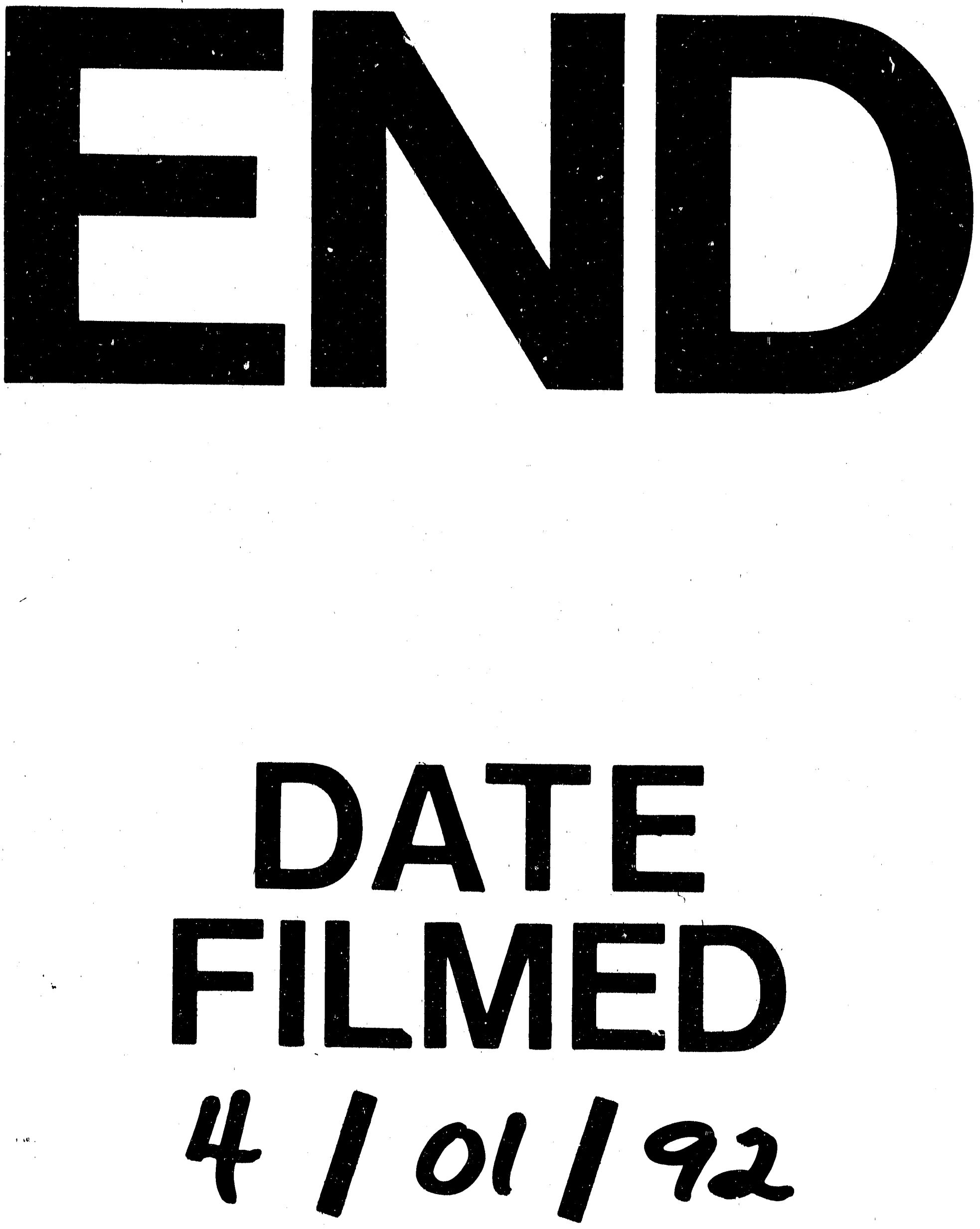
